Editora Poisson

(organizadora)

\title{
Educação no Século XXI - Volume 45 Gestão Pedagógica e Docência
}

\author{
1a Edição
}

Belo Horizonte

Poisson

2019 
Editor Chefe: Dr. Darly Fernando Andrade

\section{Conselho Editorial}

Dr. Antônio Artur de Souza - Universidade Federal de Minas Gerais

Ms. Davilson Eduardo Andrade

Dra. Elizângela de Jesus Oliveira - Universidade Federal do Amazonas

Msc. Fabiane dos Santos

Dr. José Eduardo Ferreira Lopes - Universidade Federal de Uberlândia

Dr. Otaviano Francisco Neves - Pontifícia Universidade Católica de Minas Gerais

Dr. Luiz Cláudio de Lima - Universidade FUMEC

Dr. Nelson Ferreira Filho - Faculdades Kennedy

Ms. Valdiney Alves de Oliveira - Universidade Federal de Uberlândia

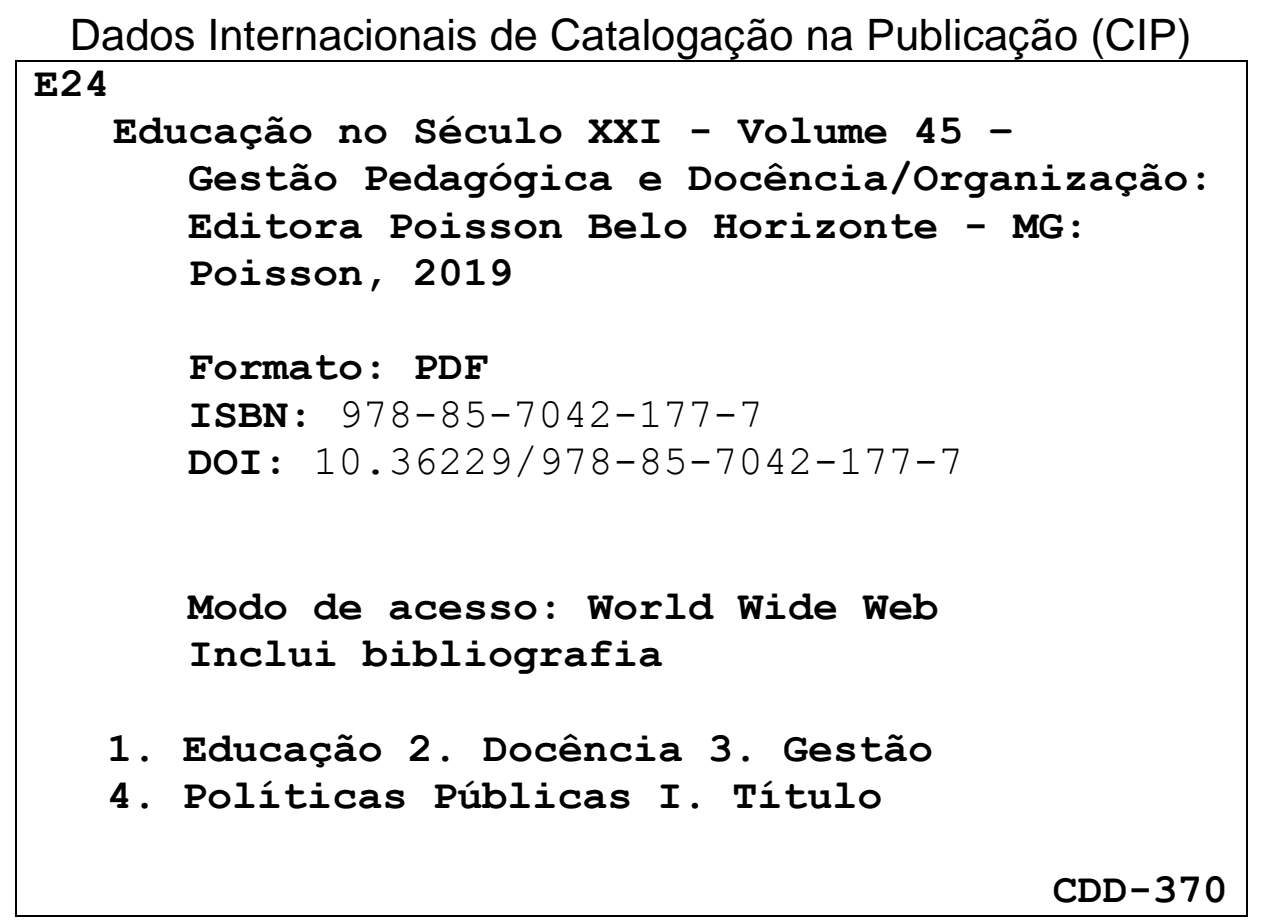

O conteúdo dos artigos e seus dados em sua forma, correção e confiabilidade são de responsabilidade exclusiva dos seus respectivos autores

$\underline{\text { www.poisson.com.br }}$

contato@poisson.com.br 


\section{SUMÁRIO}

Capítulo 1: Percepções acerca do professor reflexivo, sua formação e a prática docente 08

Zaira Dantas de Miranda Cavalcanti, Elisa Angélica Alves Guedes, Fábio André Porto Alves DOI: 10.36229/978-85-7042-177-7.CAP.01

Capítulo 2: Por uma prática contextualizada: Da Pedagogia à Educação Básica 14 Carla Sarlo Carneiro Chrysóstomo

DOI: $10.36229 / 978-85-7042-177-7 . C A P .02$

Capítulo 3: Circuito de gestão: Limites e possibilidades para uma gestão de aprendizagem 20

Maria Eveuma de Oliveira, Tadeu Teixeira de Souza, Maria Luciene Araújo da Silva, José Moisés Monteiro DOI: 10.36229/978-85-7042-177-7.CAP.03

Capítulo 4: Conselho de classe: Algumas considerações 27

Ronaldo da Silva Correa, Vanilda Alves da Silva

DOI: 10.36229/978-85-7042-177-7.CAP.04

Capítulo 5: Um breve comentário do processo e a evolução da educação superior vinculado nas universidades, empresas e governo

Rodrigo Leme Dias de Souza

DOI: 10.36229/978-85-7042-177-7.CAP.05

Capítulo 6: A abertura do espaço escolar 38

Dalton Bertini Ruas

DOI: 10.36229/978-85-7042-177-7.CAP.06

Capítulo 7: Resiliência: um estudo sobre os fatores de risco e proteção no contexto da escola. 45

Sandreia Pantoja Lobato, Michelle Carneiro Serrão

DOI: 10.36229/978-85-7042-177-7.CAP.07 


\section{SUMÁRIO}

Capítulo 8: Possibilidades de melhoria do clima e cultura organizacional através de práticas de planejamento participativo na educação.

Edna Maria Mendes Pinheiro Costa, Mailson Martinho, Maria de Lourdes Silva Lima, Vera Rejane Gomes, Osiel Cesar da Trindade Junior

DOI: 10.36229/978-85-7042-177-7.CAP.08

Capítulo 9: Por outra imagem dos docentes e da docência na educação básica: 0 papel da formação continuada. 59

Maria dos Anjos Lopes Viella, Gislene Miotto Catolino Raymundo, Marizete Bortolanza Spessatto

DOI: $10.36229 / 978-85-7042-177-7 . C A P .09$

Capítulo 10: Prática de narrativas e memórias através de um olhar docente. 68 Ana Lúcia Ferraz

DOI: $10.36229 / 978-85-7042-177-7 . C A P .10$

Capítulo 11: Alunos e professores como atores centrais: Discussões e dimensões das relações no processo de ensino e aprendizado 76

Simone Evangelista Fonseca, Cristiana Lara Cunha, Anderson Rocha de Jesus Fernandes, Sabrina Espinele da Silva, Antônio Artur de Souza

DOI: $10.36229 / 978-85-7042-177-7 . C A P .11$

Capítulo 12: Experimentando processos de formação. 83

Pollyana Aguiar Fonseca Santos, Kátia Maria Kasper

DOI: 10.36229/978-85-7042-177-7.CAP.12

Capítulo 13: Formação e práticas docentes em contextos de educação não formal e suas relações nos documentos oficiais da educação brasileira. 89

Daniela Tomio, Rocheli Rita Ronchi, Vanderlei Schmitz

DOI: 10.36229/978-85-7042-177-7.CAP.13

Capítulo 14: 0 paradigma da complexidade na prática pedagógica do professor universitário 99

Marlene de Oliveira

DOI: $10.36229 / 978-85-7042-177-7 . C A P .14$ 


\section{SUMÁRIO}

Capítulo 15: A provinha Brasil: Instrumento que diagnostica e promove a aprendizagem ou limita e aprisiona a prática docente? 106

Celi Traude Kellermann, Eliane Greice Davanço Nogueira, Ana Paula Gaspar Melim

DOI: 10.36229/978-85-7042-177-7.CAP.15

Capítulo 16: 0 pacto nacional pela alfabetização na idade certa (PNAIC) e a formação continuada do professor alfabetizador. 114

Maria Silvia Bacila

DOI: 10.36229/978-85-7042-177-7.CAP.16

Capítulo 17: Domínio teórico-prático das teorias pedagógicas de aprendizagem presentes no discurso dos docentes do curso de direito de um Campus da Universidade do Estado de Mato Grosso 123

Solange Teresinha Carvalho Pissolato, Silvana Mara Lente, Edson Roberto Oaigen

DOI: 10.36229/978-85-7042-177-7.CAP.17

Capítulo 18: A implantação da educação escolar na Estância Turística de Ouro Preto do Oeste - RO: Seleção e capacitação docente (1970 - 1980). 129

Devanir Aparecido dos Santos, Ludimilla de Souza Colodetti

DOI: 10.36229/978-85-7042-177-7.CAP.18

Capítulo 19: "Civilizar" e integrar: Educação, política e ideologia na Província do Pará após a cabanagem. 136

Denise de Souza Simões Rodrigues

DOI: 10.36229/978-85-7042-177-7.CAP.19

Capítulo 20: 0 planejamento estratégico no currículo do bacharelado em administração 145

Julio Cezar Arias, Mércia Freire Rocha Cordeiro Machado

DOI: 10.36229/978-85-7042-177-7.CAP.20

Capítulo 21: Dermeval Saviani em "História das ideias pedagógicas no Brasil” e a utilização do método abdutivo: Uma contribuição para a socialização do conhecimento. 158 


\section{SUMÁRIO}

Capítulo 22: Políticas públicas de educação e ensino médio inovador: Contribuições ao debate. 163

Luzia Mônica Lima da Frota Araújo, Francisco Jucivânio Félix de Sousa, Ellis Regina Ferreira dos Santos, Márcia Rejane Damasceno Dias

DOI: $10.36229 / 978-85-7042-177-7 . C A P .22$

Capítulo 23: A influência do Neoliberalismo nas políticas públicas para o ensino integral no Estado de São Paulo. 167

Ronaldo Costa Barbosa, Raimunda Abou Gebran

DOI: $10.36229 / 978-85-7042-177-7 . C A P .23$

Capítulo 24: Qualidade na educação básica: Benefício em todos os níveis escolares 174 Ivo José Both, Patrícia Beraldo

DOI: 10.36229/978-85-7042-177-7.CAP.24

Autores: 182 


\section{Capítulo 1}

Percepções acerca do professor reflexivo, sua formação e a prática docente

\section{Zaira Dantas de Miranda Cavalcanti \\ Elisa Angélica Alves Guedes \\ Fábio André Porto Alves}

Resumo: Investigar sobre a postura do professor reflexivo poderá contribuir nas discussões acadêmicas sobre as dificuldades e possíveis alternativas de aplicação da metodologia reflexiva no cotidiano escolar, como também fortalece a perspectiva da reflexão sobre a formação e prática docente. Assim, esse estudo objetiva apresentar as concepções do professor reflexivo na formação e prática docente amplamente discutidas na literatura. A metodologia aplicada se deu por levantamento bibliográfico de artigos científicos presentes no banco de teses da Coordenação de Aperfeiçoamento de Pessoal de Nível Superior (Capes), no Scientific Electronic Library Online (SciELO), literatura que trata do tema em anais de eventos científicos em educação. Os resultados apontam que o professor é considerado um semeador da humanização e de inclusão social através do conhecimento e da valorização do aluno através da prática e da ação reflexiva visto que a aquisição de conhecimento deve partir de um ato dialógico. Percebemos que a postura do professor reflexivo poderá propiciar maior aquisição de conhecimento teóricoprático por parte do aluno como também promover ao professor uma ação reflexiva sobre sua prática docente com o intuito de superar as barreiras existentes nessa metodologia de ensino, promovendo a formação do ser humano, tanto estudante quanto docente, de maneira integral e em sua plenitude. Concluímos com esse trabalho que o professor reflexivo contribuirá com o alcance do objetivo de formação do estudante, podendo formar um profissional atento às várias dimensões que envolvem a vida do ser humano, elencando a reflexão como atitudes cotidianas necessárias para ações na prática docente.

Palavras-chave: Professor reflexivo, Formação de professores, Prática docente.

1 Artigo apresentado do III Congresso Nacional de Educação no ano de 2016, fruto de trabalho realizado no componente curricular Professor Reflexivo e a Epistemologia da Prática Docente, sob responsabilidade do Professor Marcelo Ribeiro. 


\section{INTRODUÇÃO}

A educação com fins libertadores e promovedores da cidadania é um desafio nos dias atuais quando nos deparamos com tantas realidades sociais que nos chocam, aterrorizam e entristecem. Compreendemos que boas práticas educativas tem o poder de transformar contextos e beneficiar comunidades, se estas forem consideradas também como parte essencial do processo de formação do cidadão consciente e responsável, e que é na escola que se constitui possibilidades de diálogo, de questionamentos e de transformação (MOREIRA et al, 2015).

Todavia, diante de tantos entraves e crises enfrentadas pela escola do século XXI, é imprescindível que professores sejam conscientes da relevância de sua prática na formação de cidadãos que poderão se tornar agentes de transformação das sociedades. Afinal, na escola pós-moderna não há mais espaço para docentes que se limitam a desempenhar o papel de meros transmissores do conhecimento, desconectados de contextos em que estão inseridos e que não atentam para necessidades gritantes à sua volta. Brighente e Mesquita (2016) apresentam que a quebra do paradigma de uma educação meramente bancária se iniciou há algumas décadas atrás, porém, lamentavelmente, percebe-se a dificuldade de sua ruptura em muitos contextos escolares. Nesse sentido, entendemos que cabe envidarmos esforços para otimizar a formação de professores frente às necessidades atuais.

É perceptível também na literatura que ser um professor reflexivo/a demanda considerar as implicações socioculturais e políticas do trabalho docente, bem como implica perceber o conhecimento profissional como marcado por fatores de ordem cultural, pelas experiências pessoais e pré-profissionais marcadas pelas diferentes trajetórias de formação vivenciadas ao longo da profissão (BENASSULY, 2002).

Diante dessa perspectiva, essa investigação é considerada relevante uma vez que visa contribuir para as discussões acadêmicas sobre as dificuldades e possíveis alternativas de aplicação da metodologia interdisciplinar no cotidiano escolar, como também fortalece a perspectiva da reflexão sobre a prática docente na educação básica como mola propulsora de alcance do êxito no que se refere às múltiplas possibilidades que a interdisciplinaridade apresenta para a educação.

Considerando que falarmos sobre as concepções do professor reflexivo, bem como sua formação e prática docente são desafios a serem superados na educação, o interesse em investigar a temática proposta neste trabalho objetiva apresentar as concepções acerca do professor reflexivo, sua formação e prática docente discutidas na literatura.

\section{METODOLOGIA}

A pesquisa foi realizada mediante leitura de autores que tratam da temática pesquisada discutidos na disciplina eletiva intitulada O Professor Reflexivo e a Epistemologia da Prática do curso de mestrado do Programa de Pós-graduação Formação de Professores e Práticas Interdisciplinares (PPGFPPI/UPE) Campus Petrolina. Contemplou também a leitura de artigos científicos presentes no banco de teses da Coordenação de Aperfeiçoamento de Pessoal de Nível Superior (Capes), no Scientific Electronic Library Online (SciELO) e em anais de eventos científicos em educação de acordo com os descritores: formação de professores, prática docente e professor reflexivo.

\section{RESULTADOS E DISCUSSÃO}

A origem do termo reflexivo está relacionada em especial com os trabalhos de Jonh Dewey, em seu livro How we think publicado em 1933. Em sua obra, Dewey define a ação reflexiva como "uma consideração ativa, persistente e cuidadosa daquilo que se acredita ou que se pratica à luz dos motivos que o justificam e das consequências a que conduz" (p. 18). Essa se diferencia do ato de rotina, que é principalmente orientado pela tradição, impulso e autoridade. 0 ato de rotina reforça as ideologias dominantes, impedindo os professores de realizar grandes rupturas e experimentar opiniões alternativas (ZEICHNER, 1993).

De acordo com Pimenta (2002), é principalmente a partir dos estudos de Donald Schön que o conceito de professor reflexivo ganha popularidade, por meio de uma proposta de formação baseada na epistemologia da prática, que valoriza a prática profissional como forma de produção de conhecimento consolidada por meio da reflexão, análise e problematização. De acordo com a autora, o trabalho de Schön se dá por meio da crítica à formação a partir da racionalidade técnica, que esse autor julgava ser incapaz de dar conta da singularidade, incertezas, instabilidade e dilemas característicos do ensino. A literatura ainda defende a 
fecundidade das análises críticas iniciadas por Schön no desencadeamento de diversas pesquisas na área da formação de professores levando inclusive à discussão de temas ausentes em suas preocupações iniciais, conforme Pimenta (2002).

Considerando a escola como caminho de transformação, Souza (2014) defende a busca da excelência na docência por considerar o professor um semeador da humanização, do processo de inclusão social e um motivador do conhecimento e da prática da liberdade, que pode ajudar o aprendiz a adquirir uma nova visão de vida. Entretanto, segundo o autor, para que essa ação se efetue é necessário que primeiro o professor se eduque, busque aperfeiçoar-se, transforme-se, pois apenas após experimentar a beleza de educar-se, poderá contribuir para a construção do outro. Isso, certamente, perpassa a ideia de um processo reflexivo que todo educador precisa experimentar, o qual se traduz num olhar crítico sobre o contexto em que vive para resultar em ações e intervenções. Porto (2016) aponta que o exercício da reflexão envolve também momentos individuais e coletivos, nas quais as representações figurativas de contextualizações e representações formais, que envolve os saberes escolares e que estes devem ser elementos em associação, promovendo a interação do professor com a compreensão do aluno em relação ao que está sendo apresentado.

Nessa perspectiva, é essencial que haja entre nós, professores, a compreensão de que é através da reflexão contínua, de um pensar constante sobre a ação cotidiana que podemos analisar nossas ações e buscar aperfeiçoamento de nossa prática. Acreditamos que não poucas vezes fazemos essa reflexão de forma inconsciente e descomprometida. Pensamos, refletimos e até criticamos nossa prática, porém sem a compreensão de que esse exercício deve gerar avaliação e mudança. Na realidade, muitos de nós não aprendemos na nossa formação a executar também essa tarefa. Eis o motivo pelo qual a literatura contemporânea acerca dos desafios da educação aponta para a relevância de se incluir nos currículos de formação de professores não apenas aspectos cognitivos relacionados a cada graduação, como também elementos extra curriculares que levem à discussão e reflexão.

No ínterim da formação para a reflexão e pesquisa, um dos aspectos interessantes é que para Souza (2014) a reflexão também pressupõe pesquisa como condição básica para o profissional da educação. De fato, outrora aprendíamos em nossa formação, que além da pesquisa científica só iniciar-se após a graduação, existe, antagonicamente, o professor da pesquisa e o da prática, ou seja, do ensino, pressupondo que o que ensina e gosta do que faz, não terá perfil ou habilidade para a pesquisa. Esse pensamento provavelmente influenciou o fazer pedagógico de tantos e gerou bloqueios e mitos que impedem uma prática mais eficaz. Todavia, segundo Souza (2014), o simples fato de levantar questionamentos reconstrutivos voltados para a educação de nossos alunos, constitui-se em pesquisar, não sendo necessário ser um "profissional da pesquisa" e nessa perspectiva, todos nós devemos adquirir este saber docente, como também cabe-nos uma reconstrução constante de nosso próprio projeto pedagógico.

Desse modo, percebemos que o movimento do "professor reflexivo" tem contribuído para a crítica à perspectiva técnica e a valorização da formação através da prática e da ação reflexiva.

Porém, o entendimento da reflexão como um ato individual do professor, tendo como objetivo a transformação da prática no contexto imediato e restrito, tem sido criticado por diversos autores (DUARTE, 2003; PIMENTA, 2002). Para a superação desse limite, seria importante considerar a reflexão como prática social, tendo em vista que se trata de um ato dialógico, valorizando a importância de que ela ocorra em grupo (ZEICHNER, 1993).

Concernente aos programas de formação de professores faz-se necessário também uma visão interdisciplinar na prática pedagógica, pois conforme Souza (2014), essa visão consiste na relevância do diálogo entre os saberes, da utilização de conhecimentos de disciplinas diversas para responder à problemas e questionamentos e de entender fenômenos nos ambientes escolares sob diferentes pontos de vista. Infelizmente, essa não é uma prática comum nos contextos educacionais. Segundo Morin (2007), como se os conhecimentos não se articulassem numa interdependência, sistemas educacionais fragmentam saberes e excluem alguns em detrimento de outros, desconsiderando relações de todo e do conceito de complexidade. Para o autor, convém perceber o contexto, o global, a relação todo/partes, o multidimensional, o complexo e para isso se faz necessária uma reforma do pensamento a qual se propõe, a fim de que se favoreça a educação de hoje e do futuro, haja vista a ampla e grave inadequação entre saberes desunidos, compartimentados e problemas ou realidades cada vez mais multidisciplinares, transnacionais e globais.

As especialidades, em geral, tratam de possuir faculdades exclusivas, tornando áreas do conhecimento cada vez mais isoladas e fechadas em si. Isso não quer dizer que deva-se excluir às especificidades das 
ciências. 0 ensino eficiente de qualquer disciplina só fará sentido se houver a consciência do espaço de seu uso e da pertinência desse conhecimento para determinados contextos. É nesse sentido que Morin (2007) afirma que para que os conhecimentos sejam pertinentes, cabe a educação torná-los evidentes. 0 autor estabelece que esse é um dos saberes necessários à educação de hoje e do amanhã. Indubitavelmente, uma prática pautada em ação reflexiva acarretará a compreensão de um aspecto tão importante quanto à visão interdisciplinar, que precisa permear os currículos e ações dos processos formadores de professores em nosso país. Se permanecermos limitados a, irrefletidamente, abrir e fechar nossas gavetas de conhecimento sem perceber a necessidade e realidade complexa de contextos escolares e sem notar a conexão desses contextos com nosso país e nosso planeta, contribuímos com a formação de cidadãos alienados e despreparados para responder às questões atuais, sem competência para refletirem sobre as mesmas e serem respostas positivas em seus espaços de atuação.

Ainda corroborando com esse pensamento que elege a prática reflexiva como elemento favorecedor da aprendizagem nos contextos educacionais, Brito (2004) afirma que discussões e novos cenários de formação docente em nosso país estão se estabelecendo e apontam para a necessidade de considerar peculiaridades de contextos de ensino, novas competências e novos saberes que o ofício de professor requer neste século. Assim, pesquisas desconstroem certezas e revelam novos paradigmas de formação entendendo que o processo formativo e o conhecimento apenas, não asseguram o sucesso profissional de ensino-aprendizagem. Em sua pesquisa numa escola da rede pública de ensino, o autor constatou que a reflexão se constitui em ponto de partida para que o docente se torne investigador de sua própria prática. Na busca de respostas para entender o sentido da reflexão sob a prática docente e se é possível estabelecêla na escola, alguns autores convergem para o mesmo pensamento que propõe a formação de um profissional reflexivo.

Segundo Schön (apud BRITO, 2000) a prática profissional apresenta situações de instabilidades e incertezas que algumas vezes não são resolvidas pelo profissional, o qual não encontra respostas em seus saberes. Isso indica a busca de competências que vão além de conhecimentos técnicos adquiridos na formação. Para Brito (2000), ser um profissional reflexivo, então, significa ter a competência de perceber a prática como espaço de reflexão crítica que se configure numa problematização da realidade pedagógica através da resolução de conflitos. Trata- se, por conseguinte, de uma construção e reconstrução de seu papel no exercício profissional.

Entretanto, Pimenta (2002) apud (BRITO, 2000), por sua vez, aconselha o cuidado com a terminologia "professor reflexivo", alegando os riscos de empobrecimento da expressão nas discussões. A mesma autora enfatiza ainda que a transformação crítica da prática e solução de problemas no cotidiano escolar exigem não só reflexão, mas também a interação entre práticas escolares e espaços socioculturais, pois é essencial compreender o ensino como prática social. Uma atitude reflexiva para a autora pressupõe uma análise da prática corriqueira, contemplando aspectos sociais em que se insere, o que confirma a relevância das conexões, das relações e compreensões de contextos que ultrapassam o domínio de saberes como sugere Morin (2007) em sua teoria da complexidade.

Acerca dessa problemática, Brito (2006) acrescenta que na busca de pensar as questões do seu cotidiano e atuar sobre elas, os professores não devem ater-se apenas à resolução de problemas imediatos, mas que ampliem seus horizontes de reflexão ao ponto de atingir também a função da escola e da educação na sociedade. Isso nada mais é do que assumir uma postura política que entende a escola como prática social.

Conquanto em situações didáticas, e de forma natural, muitas vezes é comum nos deparamos com possibilidades de reflexão que possam redundar em ações abençoadoras de ambientes, especialmente no contexto de escolas públicas, essas ações ainda são incipientes e provavelmente isso ocorre como reflexo da ausência de preparo e consciência para a postura reflexiva além da carência de formação para tal postura no meio acadêmico em que fomos formados. No nosso processo de formação acadêmica, cabia-nos apenas a transmissão de conhecimentos, de saberes de forma fragmentada. Felizmente, a paixão pelo ensino e compromisso com os sujeitos que buscam a aprendizagem nos levam muitas vezes a refletir "na" e "sobre" nossa ação e redirecionarmos nossas práticas pedagógicas para agirmos a favor da construção do outro e isso é, indubitavelmente, apaixonante a despeito de pequenos obstáculos que, eventualmente, encontramos. Talvez por essa razão, Brito (2006) considere que o trabalho docente é complexo e repleto de zonas de indeterminação que se constituem em desafios para a construção e reconstrução do saber, saber-fazer e saber-ser, e nessa caminhada busca-se interação com as situações de ensino entre os pares e consigo mesmo sendo isto fruto de um trabalho reflexivo que se estabelece aos poucos e de forma contínua.

Compactuando com essas ideias e mesmo considerando que a formação de professores nos dias atuais tem 
estabelecido a reflexão como ponto central, Gimenez, Arruda e Luvuzari (2004) admitem que há uma grande diversidade de definições e propostas de implementação, como também diversos propósitos para sua adoção. Para as autoras, o profissional reflexivo é sempre considerado como aquele que constrói e reconstrói sobre sua prática à partir de questionamentos. No entanto, as formas de reconstrução desse conhecimento são variadas. Apoiando-se em ideias de Grimmet (1988), as autoras revelam que embora a reflexão esteja presente hoje no contexto da formação de professores, há ainda pouco compartilhamento sobre o que configura essa reflexão e que espaços seriam mais favoráveis ao seu desenvolvimento. Compreendendo que o conhecimento derivado de pesquisas sobre o tema favorece a formação do professor, as autoras expõem que tal busca pode direcionar a prática de professores e identificar novas possibilidades de ação. Isso, então, proporcionaria aos professores construírem uma consciência madura sobre sua prática, bem como se emanciparem de distorções sociais políticas e culturais que podem frustrar e dificultar sua compreensão.

Diante da discussão fomentada referente a postura do professor reflexivo e através de uma reflexão crítica enquanto docentes, torna-se possível ter consciência de finalidades de saberes e a quem eles representam ou beneficiam. As autoras estabelecem que esses entendimentos passem a serem mais esclarecedores à medida que são analisadas as práticas usadas no processo de educação de profissionais reflexivos, como também à medida que nos apropriamos dos diferentes olhares sobre práticas de reflexão na formação dos professores apresentados na literatura.

\section{CONCLUSÃO}

Diante dos estudos apontados na literatura, percebemos a ênfase direcionada para a educação com fins libertadores e promovedores da cidadania. Foi apresentado também que boas práticas educativas tem o poder de transformar contextos sociais e formar o cidadão consciente e responsável, sendo a escola o locus de possibilidades de diálogo, de questionamentos e de transformação fazendo-se necessário nesse contexto a atuação do professor reflexivo.

Apresentamos também a dificuldade de se romper com a educação meramente bancária em muitos contextos escolares, cabendo a formação do educador esforços para otimizar a formação de professores reflexivos frente às necessidades atuais de educação. Ainda sob a proposta de formação baseada na epistemologia da prática, foi percebida a valorização da prática profissional como forma de produção de conhecimento consolidada por meio da reflexão, análise e problematização.

A literatura ainda aponta que o professor é um semeador da humanização, do processo de inclusão social e um motivador do conhecimento e da prática da liberdade, que pode ajudar o aprendiz a adquirir uma nova visão de vida através de um olhar crítico sobre o contexto em que vive para resultar em ações e intervenções mediadas por si próprio. Desse modo, percebemos que o professor tem contribuído para a valorização da formação do aluno através da prática e da ação reflexiva visto que se trata de um ato dialógico, valorizando a importância de que ela ocorra em grupo.

Mediante a pesquisa realizada, foi notório a percepção de que para a formação do professor reflexivo fazse necessário também uma visão interdisciplinar na prática pedagógica, visto que esta prática contempla um diálogo entre os saberes, utilização de conhecimentos de disciplinas diversas para responder a problemas e questionamentos e capacita o entendimento referente aos ambientes escolares sob diferentes pontos de vista, mesmo esta não sendo uma prática comum nos contextos educacionais da atualidade.

A literatura ainda apresentou que ser um profissional reflexivo, significa ter a competência de perceber a prática como espaço de reflexão crítica que se configure numa problematização da realidade pedagógica através da resolução de conflitos. Vimos também que os professores não devem ater-se apenas à resolução de problemas imediatos, mas que ampliem seus horizontes de reflexão ao ponto de atingir também a função da escola e da educação na sociedade. Isso nada mais é do que assumir uma postura política que entende a escola como prática social.

Portanto, as concepções apontados na literatura para a prática efetiva de uma postura de professor reflexivo contemplam uma postura pessoal e coletiva visando a melhor aquisição de conhecimento dos seus alunos. Desse modo concluímos então, que o professor que atua de forma reflexiva poderá contribuir com o alcance do objetivo de formação do estudante atento às modificações no mundo contemporâneo e, resiliente, no sentido da perspicácia para a resolução das questões que estão postas hodiernamente na sociedade, bem como atento às várias dimensões que envolvem a vida do ser humano, elencando a contemplação e a reflexão como atitudes cotidianas necessárias para ações que estejam inscritas na esfera da prática docente. 


\section{REFERÊNCIAS}

[1] Benassuly, J. S. A formação do professor reflexivo e inventivo. In: LINHARES, C.; LEAL, M. C. (orgs.): Formação de professores uma crítica à razão e às políticas hegemônicas. Rio de Janeiro, DP\&A, 2002.

[2] Brighente, M. F.; Mesquida, P. Paulo Freire: da denúncia da educação bancária ao anúncio de uma pedagogia libertadora. Pro-Posições, Campinas , v. 27, n. 1, p. 155-177, Abr. 2016.

[3] Brito, A. E. O significado da reflexão na prática docente e na produção dos saberes profissionais do/a professor/a. Revista ibero-americana de Educación (On line), v.37/8, 2006.

[4] Duarte, N. Conhecimento tácito e conhecimento escolar na formação do professor (por que Donald Schön não entendeu Luria). Educ. Soc., v. 24, n. 83, p. 601-625, agosto 2003.

[5] Gimenez, T.; Arruda, N. I. L.; Luvuzari, L. H. Procedimentos reflexivos na formação de professores: uma análise de propostas recentes. Revista Intercâmbio, V. XIII, 2004.

[6] Grimmett, P. Introduction. In: grimmett, P.P.; Erickson, G.L. (orgs). Reflection in teacher education. New York: Teachers College Press, 1998.

[7] Moreira, J. O.; Melgaço, P.; Albuquerque, B. S.; Rocha, B. F.; Ribeiro, A. C. F. A escola e a semiliberdade: a importância do diálogo. Psicol. rev. (Belo Horizonte), Belo Horizonte, v. 21, n. 1, p. 50-65, jan. 2015.

[8] Morin, E. Os Sete Saberes Necessários à Educação do Futuro. 12. ed., São Paulo: Cortez, 2007.

[9] Pimenta, S. G. Professor Reflexivo: Construindo uma crítica. In: Pimenta, S. G.; Souza, G. A. Dias B. Qual o perfil do professor do século XXI? Revista Recorte (On line), v.11, n. 1, 2014.

[10] Porto, Fábio. Saberes profissionais, práxis interdisciplinar e formação de professores do ensino médio integrado ao técnico na perspectiva da complexidade. IN: VI Encontro de Pesquisa Educacional em Pernambuco. Juazeiro-BA. Anais. Univasf, 2016.

[11] Zeichner, Kenneth M. A formação reflexiva de professores: ideias e práticas. Lisboa: Educa, 1993. (Educa: Professores; 3 ). 


\section{Capítulo 2}

\section{Por uma prática contextualizada: Da Pedagogia à Educação Básica}

\section{Carla Sarlo Carneiro Chrysóstomo}

Resumo: Este trabalho tem como objetivo apresentar a importância do estágio curricular supervisionado unindo a teoria com a prática do Curso de Pedagogia com a Educação Básica no ISEPAM. A metodologia utilizada nessa pesquisa qualiquantitativa utilizou alunos do sexto período do Curso de Pedagogia e do terceiro ano do Curso Normal Médio no primeiro semestre de 2018, para a aplicação de contação de histórias através do aplicativo toon doo, na Educação Infantil e nas primeiras séries do Ensino Fundamental I, reduzindo o número de estagiários da Pedagogia que não vivenciavam a prática na sala de aula no campo de estágio, dentre outros resultados como a evolução dos alunos do Curso Normal em sua trajetória educacional. 0 estágio é uma etapa preparatória para a prática profissional que interliga a teoria e a prática com a inserção do aluno no espaço sócio institucional. Lima (2006) explica que o mundo atual necessita de um novo tipo de profissional, cujos saberes sejam polivalentes e, sobretudo, amplos e sólidos, para corresponder às peculiaridades e ao caráter multifacetado da prática pedagógica. 0 desafio consiste na formação de profissionais que saibam atuar sobre as demandas cotidianas, analisando-as criticamente de modo a enfrentá-las. Schön (2000) destaca que o desenvolvimento de um ensino prático reflexivo pode somar-se a novas formas de pesquisa sobre a prática e de educação. Libâneo (2014) ressalta que os pedagogos e docentes têm suas atividades mutuamente fecundadas na experiência profissional das questões de ensino e aprendizagem das matérias que se interpenetram.

Palavras-Chave: Prática Pedagógica, Estágio, Formação Profissional. 


\section{INTRODUÇÃO}

Este artigo tem como objetivo apresentar a importância do estágio curricular supervisionado unindo a teoria com a prática do Curso de Pedagogia com a Educação Básica no ISEPAM.

A sociedade contemporânea se apresenta em múltiplas facetas com um elevado grau de diversidade e diferenças que não podem ser consideradas como deficiências tendo em vista a complexidade do ser humano e suas inter-relações de aprendizagem. Desta forma, faz-se necessário esse repensar em torno do referido tema como fator preponderante a mudanças em busca de uma nova prática educativa.

Zabala (1998) afirma que a prática educativa precisa partir de situações concretas buscando explicações para a realidade sem perder o sentido da relação ensino/aprendizagem. Uma prática dinâmica e reflexiva se torna peça chave de uma intervenção pedagógica ao planejamento, a aplicação e a avaliação.

Pimenta (2011) salienta para a questão relevante do esvaziamento dos estudos sistemáticos de educação e a descaracterização profissional do pedagogo, tendo em vista um contingente maciço de egressos dos cursos de Pedagogia, que curiosamente não estudaram o mesmo em sua teoria e sua prática, ignorando determinantes institucionais, históricos e sociais.

Libâneo (2014) ressalta que pedagogo é o profissional que atua em várias instâncias da prática educativa intervindo direta ou indiretamente na formação humana e em sua contextualização histórica.

A metodologia utilizada é qualiquantitativa, pois é bibliográfica, além de apresentar dados percentuais de frequência de estagiários do curso de Pedagogia no campo de estágio no primeiro semestre e no segundo semestre de 2018 no ISEPAM.

O referencial teórico utilizado contempla autores como Libâneo (2014), Pimenta (2011), Zabala (1998), Lima (2006), Schön (2000), dentre outros que muito contribuíram para essa investigação tão pertinente aos dias atuais.

\section{METODOLOGIA}

\subsection{A FORMAÇÃO DE PROFESSORES E O DESEMPENHO PROFISSIONAL DOS PEDAGOGOS}

Libâneo (2014) apresenta um panorama educacional que envolve a estrutura do conhecimento pedagógico e a identidade profissional do pedagogo no contexto das novas realidades econômicas, políticas e culturais do mundo contemporâneo. Desta forma,

É o que se pode ver por exemplo na insistência em temas como: a docência como base da identidade profissional de todo educador, a divisão do trabalho na escola, a separação conteúdo-métodos, a escola como local de trabalho capitalista. Junto a essas dificuldades, é visível que a profissão de pedagogo, como a de professor, tem sido abalada por todos os lados: baixos salários, deficiências de formação, desvalorização profissional implicando baixo status social e profissional, falta de condições de trabalho, falta de profissionalismo etc. Esses fatores, por sua vez, rebatem na desqualificação acadêmica da área, fazendo com que docentes e pesquisadores de outras áreas desconheçam a especificidade da Pedagogia, embora a critiquem (LIBÂNEO, 2014, p. 26).

0 referido autor explica a necessidade de haver uma discussão sobre o campo específico da Pedagogia e o exercício profissional do pedagogo.

Pimenta (2011) afirma que a crítica de que o curso de Pedagogia de 1969 é "tecnicista" parece pertinente aos dias de hoje. Assim, "junto a isso, são agregadas às críticas à fragmentação da formação do pedagogo, à divisão técnica do trabalho na escola, à separação entre a teoria e a prática, à separação entre o pedagogo especialista e o trabalho docente" (PIMENTA, 2011, p. 23). A fragmentação de tarefas e consequentemente suas funções, comprometeu a existência de especialistas na escola nos seguintes aspectos:

(a) Caráter "tecnicista" do curso e o consequente esvaziamento teórico da formação, excluindo o caráter da Pedagogia como investigação do fenômeno educativo; (b) o agigantamento da estrutura curricular que leva ao mesmo tempo a um currículo fragmentado e aligeirado; (c) a fragmentação excessiva de tarefas no âmbito das escolas; (d) a separação no currículo entre os dois blocos, a formação pedagógica de base e os estudos correspondentes às habilitações (PIMENTA, 2011, p. 24). 
A autora citada acima constata o esvaziamento dos estudos sistemáticos de educação e a descaracterização profissional do pedagogo como questões relevantes nos estudos disciplinares das áreas das metodologias.

Libâneo (2014) ressalta que a educação é o conjunto de ações que se relacionam de forma ativa com o meio natural e social em um determinado contexto de relações ente grupos e classes sociais. Por isso, "[...] Numa sociedade em que as relações sociais baseiam-se em relações de antagonismo, em relações de exploração de uns sobre outros, a educação só pode ter cunho emancipatório, pois a humanização plena implica a transformação dessas relações" (LIBÂNEO, 2014, p. 30). Sendo assim, a educação ocorre na família, no trabalho, na rua, na fábrica, nos meios de comunicação e na política.

Orlandi (2012) argumenta que a relação universidade /comunidade tem sido definida e debatida como prestadora de serviços traduzida como "filantropia intelectual", "salvacionismo", uma espécie de prontosocorro universitário em forma de paternalismo, que por sua vez, é um autoritarismo com disfarces. Portanto,

O que temos visto é a escalada, cada vez maior, da "escolarização" a todos os níveis de reflexão, reduzindo-se assim a vida intelectual a menos programas curriculares em que a preocupação maior está em parecer "crítica". Dessa forma, o que se viu na realidade é cumprir compromissos formais e burocráticos: horas aula, créditos, e até mesmo incluir disciplinas modernosas em cursos básicos, para mostrar como se "envidam esforços no atendimento dos interesses e dificuldades reais da comunidade" etc. (ORLANDI, 2012, p. 43/44).

A autora supracitada explica que a interação entre a universidade e os outros setores da sociedade não devem ter a forma de prestação de serviços, mas sim articular de forma clara e crítica com as outras instâncias institucionais.

\section{A INTERDISCIPLINARIDADE DO ESTÁGIO DA PEDAGOGIA À EDUCAÇÃO BÁSICA}

O estágio profissionalizante faz com que o estudante inicie o exercício da construção de sua identidade profissional e sinta na prática a grande responsabilidade que carrega, estreitando compromissos com os alunos, seus familiares, a comunidade e a instituição escolar. 0 mesmo possibilita aos futuros professores a construção de saberes vinculados ao futuro campo de trabalho. Portanto,

[...] a aproximação do futuro professor à realidade escolar acontece após ter passado pela formação "teórica" tanto na disciplina específica como nas disciplinas pedagógicas. 0 caminho deve ser outro. Desde o ingresso dos alunos no curso, é preciso integrar os conteúdos das disciplinas em situações da prática que coloquem problemas aos futuros professores e lhes possibilite experimentar soluções. Isso significa ter a prática, ao longo do curso, como referente direto para contrastar seus estudos e formar seus próprios conhecimentos e convicções a respeito. Isso quer dizer que os alunos precisam conhecer o mais cedo possível os sujeitos e as situações com que irão trabalhar (PIMENTA, 2011, p. 55).

A autora citada acima destaca que a prática profissional precisa ser vista de forma permanente e sistemática na aprendizagem como referência para a organização curricular.

Segundo Zabala (1998) o bom profissional precisa ser competente sabendo utilizar o conhecimento e a experiência adquirida para intervir na prática de forma adequada. Portanto,

Alguns teóricos da educação, a partir da constatação da complexidade das variáveis que intervém nos processos educativos, tanto em número como em grau de interrelações que se estabelecem entre elas, afirmam a dificuldade de controlar esta prática de forma consciente. Na sala de aula acontecem muitas coisas ao mesmo tempo, rapidamente e de forma imprevista, e durante muito tempo, o que faz com que se considere difícil, quando não impossível, a tentativa de encontrar referências ou modelos para racionalizar a prática educativa (ZABALA, 1998, p. 14). 
O autor acima explica que a ação inicia a reflexão e que a capacidade reflexiva do profissional necessita de meios teóricos que contribuam para que a análise da prática seja verdadeiramente reflexiva extraída do estudo empírico e da determinação ideológica que permitam fundamentar a prática para possíveis alternativas de mudanças. Desta forma, se concretizará a função social do ensino e o conhecimento de como se aprende.

Tendo em vista uma realidade educacional globalizada, Libâneo (2014) destaca que "[...] a intencionalidade da prática educativa tem implicações diretas no posicionamento crítico do educador que representa o elo fundamental no processo de formação cultural e científica das novas gerações" (LIBÂNEO, 2014, p. 150). Essas são algumas exigências contemporâneas da formação dos pedagogos e professores que assumirão as práticas educativas na sociedade globalizada, com o objetivo de forçar o crescimento dos sistemas educacionais, abrindo campos de atuação profissional do pedagogo nos âmbitos escolar e extraescolar.

Barreto (2014) aborda o trabalho docente no campo educacional com novos contornos e estratégias políticas, econômicas e jurídicas para superar a crise capitalista iniciada ao fim dos anos 1960/1970. 0 conjunto de políticas destinado a produzir mudanças no sistema educativo coloca às TIC em um lugar central em suas formulações. Portanto,

Há, também na produção acadêmica, diversos textos sobre educação que defendem a incorporação das tecnologias, ressignificadas como imprescindíveis à modernização da escola, equiparando-a a outros setores da sociedade nos quais as tecnologias estão quase que "naturalmente" presentes e que entendem sua inclusão no processo educacional como uma forma de "democratização" e de acesso à informação. Essas perspectivas atribuem às tecnologias o caráter de positividade nas mudanças propostas para/na educação, assim como o lugar de impulsionadoras das mudanças tidas como desejáveis para que as escolas contribuam para a "formação de capital humano" e fomentem a chamada "sociedade do conhecimento" (BARRETO, 2014, p. 34).

A autora citada acima aborda a importância do trabalho docente compatível com a revolução científico tecnológica, orientada para estratégias de substituição tecnológica de docentes e de EAD para formação de professores para certificação em massa, utilizando de forma adequada às TIC.

\section{RESULTADOS E DISCUSSÃO}

Para ressignificar o uso das tecnologias no curso Formação de Professores do ISEPAM foram construídas histórias em quadrinhos, pelos respectivos alunos, através do aplicativo da Web 2 Toon Doo com histórias modernas, poesias e músicas, sempre deixando o último quadrinho uma pergunta em aberto para estimular a imaginação criadora do leitor. Portanto, "as HQ's possibilitam o diálogo com as mais distintas faixas etárias e classes sociais, além de permitir infindáveis mediações, reflexões e vieses. Como expressão singular e polissêmica, valorizam a subjetividade e atuam como significativa memória" (BARRETO, 2014, p. 137). As tecnologias da sala de aula não operam de maneira dissociada do mundo real como receita de bolo. Como exemplo a história abaixo: 


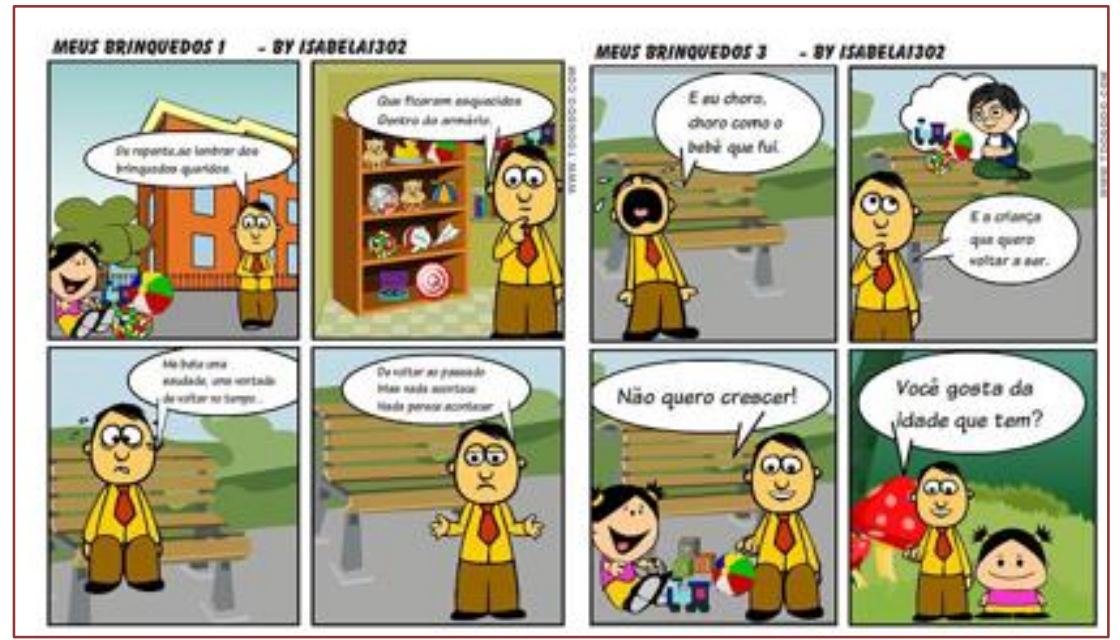

Fonte: aluna do curso Formação de Professores

Os alunos do curso Pedagogia do ISEPAM em seu campo de estágio no sexto período, os quais necessitam vivenciar práticas de ensino referentes às disciplinas pedagógicas no Ensino Médio, acompanharam as alunas do Ensino Médio na fase de aplicação das histórias na Educação Infantil e nas primeiras séries do Ensino Fundamental I. Esse tipo de trabalho docente segundo Freitas apud Barreto (2014, p. 39) que "as operações ideológicas empreendidas metamorfoseiam o trabalho em "atividades" e "tarefas" do professor, termos estes sustentados pelas categorias da "prática e da prática reflexiva". Em plena globalização é de fundamental importância a flexibilização do trabalho docente reconfigurando as políticas educacionais.

De acordo com o gráfico abaixo pode-se verificar que dos 60 alunos do 6o período, distribuídos em duas turmas, 17 alunos consideram o estágio sem importância para a sua formação, explicando que não aprendem nada, que a maioria dos professores não planeja de forma dinâmica e 43 consideram imprescindível para o seu crescimento profissional, principalmente após essa relação interdisciplinar com a Educação Básica podendo intervir e avaliar, nas aulas de contação de histórias, configurando $28 \%$ do total.

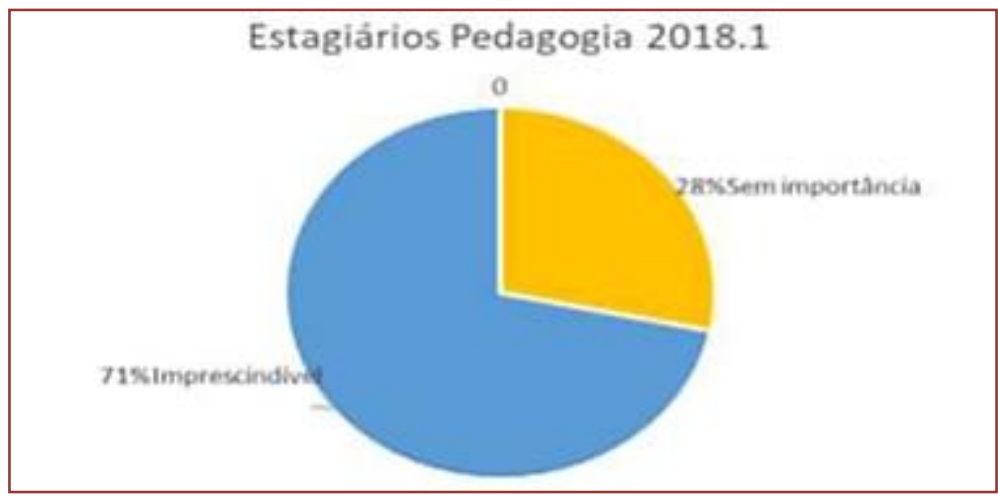

Fonte: a autora

A proposta foi provocar o diálogo com o mundo de fora da escola; dos alunos da Pedagogia com os alunos da Educação Básica, mostrando que é possível um discurso polêmico a partir do discurso lúdico, um estágio com sentido que se apropria da união da teoria com a prática, porque não há prática pedagógica neutra, sem intencionalidade. Pimenta (2011) destaca que a educação que tem por finalidade a humanização do homem integra o sentido emancipatório às suas ações desencadeando ações formadoras e incentivadoras, produzindo a transformação democrática da realidade. 


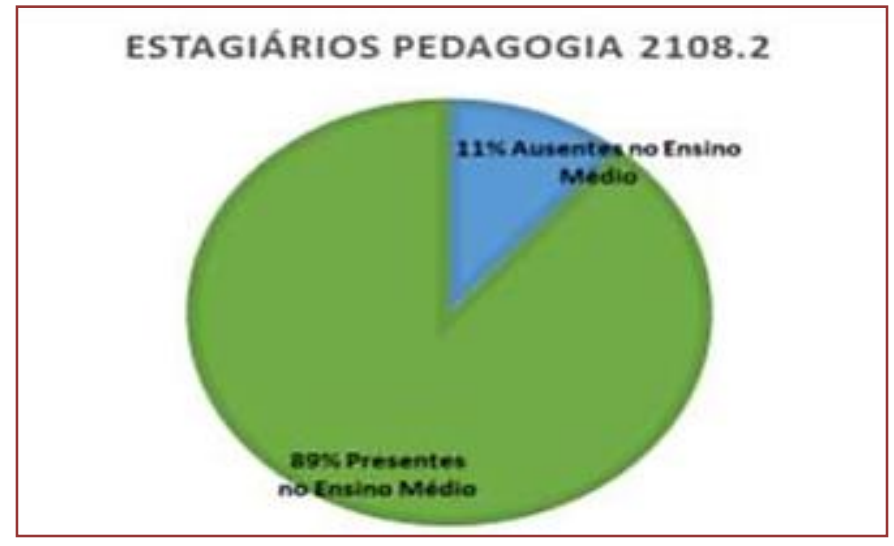

Fonte: a autora

Em um universo de 90 alunos distribuídos em três períodos em 2018.2, verifica-se após os dados do gráfico acima, que a relação reflexiva, dialógica e crítica desenvolvida no campo de estágio da Pedagogia estimularam o aumento da frequência no estágio no Ensino Médio descaracterizando as falas recorrentes: "desnecessário", "desestimulante", "perda de tempo", "não aprendo nada". Tudo depende do olhar de quem supervisiona e de quem ministra as aulas do Ensino Médio em uma grande parceria.

\section{CONCLUSÕES}

O estágio supervisionado é visto como tendo influência negativa para a opção pela carreira do magistério, mostrando-se desestimulante principalmente por se tratar de escola pública, pela precariedade da infraestrutura física apontada nos relatórios, assim como a falta de entusiasmo dos professores e comprometimento nos planejamentos associados as dificuldades por eles enfrentadas.

Mudar a feição da prática de ensino e estágio supervisionado não é tarefa fácil porque necessita de disciplinas que dialoguem de forma reflexiva e crítica buscando encontrar caminhos que favoreçam um melhor desempenho dos alunos estagiários no enfrentamento dos desafios do ensino público, principalmente o fracasso escolar, que gera o desestímulo do alunado, compromete a ação docente e, de certa forma, desarticula o processo educacional.

Pode-se verificar através dos alunos que quando o estágio serve de ponte para a reflexão crítica em busca de uma práxis interdisciplinar o resultado é satisfatório servindo para buscar novas estratégias de mudança com novos olhares de educadores aprendizes.

\section{REFERÊNCIAS}

[1] Barreto, Raquel Goulart. Tecnologias e trabalho docente: entre políticas e práticas. 1a edição. Petrópolis, RJ: De Petrus et Alii: Rio de Janeiro, RJ: Faperj, 2014.

[2] Libâneo, José Carlos. Pedagogia e Pedagogos, para quê?12ª edição. São Paulo: Cortez Editora, 2014.

[3] Lima, Maria da Glória Soares Barbosa. Sujeitos e saberes, movimento de autorreforma da escola. In: Mendes Sobrinho, José Augusto de Carvalho; Carvalho, Marlene Araújo de (Orgs.). Formação de professores e práticas docentes: olhares contemporâneos. Belo Horizonte: Autêntica, 2006.

[4] Orlandi, Eni Pulcinelli. Discurso e Leitura. 9ae edição. São Paulo: Cortez Editora, 2012.

[5] Pimenta, Selma Garrido (org.). Pedagogia e Pedagogos: caminhos e perspectivas. 3a edição. São Paulo: Cortez Editora, 2011.

[6] Schon, D. Educando o Profissional Reflexivo: um novo design para o ensino e aprendizagem. Trad. Roberto Cataldo Costa. Porto Alegre: Artes Médicas Sul, 2000. http://www.toondoo.com/histórias em quadrinhos; acessado em 03/03/2017. 


\section{Capítulo 3}

\section{Circuito de gestão: Limites e possibilidades para uma gestão de aprendizagem}

Maria Eveuma de Oliveira

Tadeu Teixeira de Souza

Maria Luciene Araújo da Silva

José Moisés Monteiro

Resumo: 0 presente artigo tem por objetivo analisar como se deu a implementação do Circuito de Gestão do Projeto Jovem de Futuro na EEM Josefa Alves Bezerra, na Vila São Pedro, Jucás/CE. O Circuito de Gestão é um método de gestão específico, que tem por objetivo orientar, organizar e sistematizar os principais processos e procedimentos da gestão escolar. 0 Jovem de Futuro é uma estratégia de Gestão Escolar orientada para Resultados de Aprendizagem que tem como objetivo o aperfeiçoamento da Gestão Escolar. Compõem-se a metodologia, além do acompanhamento das ações elaboradas pela escola através do seu Plano de Ação, utilizou-se um questionário aplicado ao Núcleo Gestor da Escola, professores, alunos e funcionários para perceber se a escola incorporou esse método e se as ações planejadas são de conhecimento de todos os atores envolvidos no processo e se os mesmos acreditam que o método contribui para melhoria dos resultados; pois o desafio dos gestores é produzir um bom diagnóstico, elaborar um planejamento sistematizado, agir conforme planos e metas, monitorar as ações e corrigir rotas para que o Circuito seja efetivado no espaço escolar. Nosso trabalho está pautado nos estudos de BOLIVAR (2012), LUCK (2000, 2009, 2010), entre outros teóricos. Diante das análises realizadas e do questionário respondido pela equipe escolar, podemos verificar que a escola se percebe no Circuito buscando nas suas ações melhoria para aprendizagem dos alunos. Portanto, espera-se com esse trabalho contribuir de forma efetiva para que os gestores possam perceber o método como uma ferramenta de gestão que não só subsidiará seu trabalho, mas também, dará resultados positivos impactando diretamente na aprendizagem dos alunos.

Palavras-chaves: Circuito de Gestão, Jovem de Futuro, Resultados, Aprendizagem. 


\section{CONSIDERAÇÕES INICIAIS}

O Circuito de Gestão é um método de gestão para orientar, organizar e sistematizar os processos e procedimentos da Gestão Escolar. Foi desenhado para preparar e apoiar, com conhecimentos teóricos e técnicos, os gestores escolares. Com o Circuito espera-se melhorar a qualidade técnica da gestão das escolas porque melhorando a gestão, espera-se melhorar a gestão pedagógica visando a melhoria da aprendizagem dos estudantes onde todas as rotinas da escola deverá ser voltada para o pedagógico. Nesse sentido é importante destacar que:

0 foco em resultados de aprendizagem estabelece um farol no caminho da garantia do direito à educação de qualidade. A qualificação técnica da gestão possibilita às equipes escolares atuar com mais segurança e precisão, fazendo com que todas as atividades tenham como propósito final assegurar o aprendizado dos estudantes.(HENRIQUES, 2007, pág. 7).

$\mathrm{Na}$ busca pela melhoria da aprendizagem o Instituto Unibanco visa contribuir com a qualidade da educação pública, tendo como foco de atuação a melhoria do Ensino Médio. Para isso, desenvolve ações em busca de resultados efetivos, que possam inspirar práticas inovadoras e contribuir com as políticas públicas; por isso desenvolveu o Jovem de Futuro (JF), que é uma tecnologia educacional concebida para o aperfeiçoamento contínuo da gestão

escolar orientada para resultados de aprendizagem, principal projeto da organização.

0 artigo tem como tema central o Circuito de Gestão que foi implementado em todas as Escolas de Ensino Médio Regular, do Estado do Ceará, exceto, aquelas que, pelas suas especificidades, não participaram da implantação. São as seguintes: Escolas Indígenas; Escolas Quilombolas; CEJAs, Instituto de Educação dos Cegos; Instituto de Educação dos Surdos e Instituto de Educação do Ceará.

o Circuito de Gestão permite aos gestores escolares a precisão e o rigor necessário para lidar com a complexa realidade escolar, identificando desafios e potencialidades para construção de melhores caminhos e tomadas de decisões mais acertadas. (PercursoFormativo, pág. 76, 2017)

Assim, esse estudo tem como propósito verificar como o Circuito de Gestão foi implementado na EEM Josefa Alves Bezerra de forma efetiva e coletiva; bem como analisar se a escola acredita que esse método contribuirá na aprendizagem dos alunos.

A importância do trabalho é perceber se o Circuito de Gestão contribui efetivamente no alcance da Meta da escola e na melhoria da aprendizagem dos alunos. Tem como propósito servir como fonte de pesquisa de uma prática diferenciada visando mostrar o seu impacto no espaço escolar.

\section{METODOLOGIA}

A metodologia do trabalho busca analisar, através de um questionário, como a escola tem realizado suas ações para perceber se ela está utilizando o Circuito de Gestão como método para melhoria de seus resultados. Optou-se por uma metodologia de caráter exploratório com abordagem qualitativa, constando de relato da aplicação do questionário realizado na EEM Josefa Alves Bezerra, localizada na Vila São Pedro, em Jucás/CE.

Inicialmente, aplicou-se um questionário com os seguintes segmentos da escola: Núcleo Gestor, professores, alunos e funcionários com questões relativas a implementação do Circuito de Gestão, mas, infelizmente, o desafio maior foi o envolvimento dos pais nas ações da escola e participação de projetos, por isso é o único segmente que não é contemplado na pesquisa. .

Foram entregues quatro perguntas relacionadas a implementação do Circuito de Gestão na Escola para ser respondido pelos seguintes atores envolvidos no processo: Dupla Gestora, três professores de áreas diferentes, três funcionários, todos os líderes de sala e um outro representante de aluno dos turnos manhã

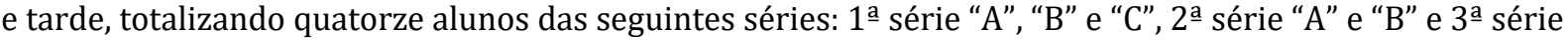
"A" e "B". 
Dividiu-se o trabalho da seguinte forma: situarei o leitor sobre a pesquisa realizada, mostrarei o que é Jovem de Futuro e sua trajetória como ferramenta de gestão, apresentaremos o método do Circuito de Gestão e finalizaremos mostrando como a EEM Josefa Alves Bezerra implementou esse método. Pautou-se em estudos desses (as) pesquisadores (as) e estudiosos sobre o assunto: BOLIVAR (2012), LUCK (2000, 2009, 2010), SOARES, T. F, além do material utilizado nas formações no estado pelo Instituto Unibanco.

Finalizaremos nossas reflexões analisando como a escola está utilizando o Circuito de Gestão verificando seus limites e possibilidades para uma gestão de aprendizagem.

\section{PROJETO JOVEM DE FUTURO/PJF}

O Jovem de Futuro, concebido e desenvolvido pelo Instituto Unibanco, busca contribuir para uma educação pública de qualidade que garanta o acesso, a permanência e a conclusão dos jovens no Ensino Médio, proporcionando o aprendizado esperado no tempo adequado.

O Jovem de Futuro (JF) é uma tecnologia educacional desenvolvida e testada para estimular o aprimoramento contínuo da gestão escolar, com o objetivo de melhorar os resultados de aprendizagem dos estudantes, expandir o número de concluintes e reduzir as desigualdades educacionais de escolas públicas de Ensino Médio (Disponível em http://jovemdefuturo.org.br/o-que-e/)

Para isso, o Jovem de Futuro parte do princípio de que a gestão escolar de qualidade proporciona um impacto significativo nos resultados da escola, segundo a concepção do projeto, para obter essas implicações positivas, a gestão deve possuir e articular as dimensões Política Pedagógica, Administrativa, e Democrática e Participativa. Essas três dimensões, em conjunto, compõem a gestão escolar de qualidade.

Segundo o Instituto Unibanco no fim desse período, "a avaliação de impacto constatou que os alunos das escolas atendidas tiveram um avanço no aprendizado de Língua Portuguesa e Matemática mais significativo do que os estudantes das escolas não participantes" (Percurso Formativo, 2017, pág11). Além de permitir identificar os impactos positivos da proposta no aprendizado dos estudantes, a fase piloto possibilitou acumular experiências e detectar os ajustes necessários para a disseminação do projeto em larga escala.

Nesse sentido é importante destacar que:

Entre 2012 e 2014, o projeto Jovem de Futuro foi integrado ao Programa Ensino Médio Inovador - ProEMI, do Ministério da Educação - MEC. A articulação permitiu que a iniciativa fosse disseminada nas redes públicas de ensino do Ceará, de Goiás, Mato Grosso do Sul, Pará e Piauí. Nessas unidades da federação, a partir da parceria das Secretarias de Educação com o Instituto Unibanco e o Ministério da Educação, o programa consolidou-se como uma política pública para o Ensino Médio. (Percurso Formativo, 2017, pág12).

0 percurso vivenciado ao longo dos anos nesses estados permitiu que o Jovem de Futuro ingressasse em uma nova fase, que busca aprofundar e ampliar o escopo das ações voltadas para o aprimoramento da gestão.

A estratégia Jovem de Futuro 3a Geração, em 2017, foi implementada em todas as Escolas de Ensino Médio Regular, do Estado do Ceará, exceto, aquelas que, pelas suas especificidades, não participaram da implantação. São as seguintes: Escolas Indígenas; Escolas Quilombolas; CEJAs, Instituto de Educação dos Cegos; Instituto de Educação dos Surdos e Instituto de Educação do Ceará. Nesse novo formato foram definidas metas de IDE Médio por escola e por estado; definição de escolas prioritárias sem avaliação de impacto; Circuito de Gestão com procedimentos determinados; protocolos para Secretaria de Educação do Estado do Ceará - SEDUC e escolas da rede estadual; estado assumindo a formação semipresencial dos gestores; Desvinculação com os programas federais.

O Instituto Unibanco desenvolveu uma Plataforma online de gestão de projetos das escolas e formação a distância. Atualmente é composta pelo Sistema de Gestão de Projetos (SGP) e pelo Ambiente Virtual de Aprendizagem (AVA). A plataforma permite às escolas construir os seus Planos de Ação, de forma alinhada às diretrizes do MEC. $\mathrm{O}$ JF inclui, para acompanhamento, uma sistemática de visitas e reuniões, cujo agendamento, registro de atas e outras funções são realizadas com o auxílio da Plataforma Jovem de Futuro. 


\subsection{MÉTODO: CIRCUITO DE GESTÃo}

Para a concretização de uma gestão escolar orientada para resultados de aprendizagem nas escolas, o Jovem de Futuro previu a implementação do Circuito de Gestão, um método de gestão específico, que tem o objetivo de orientar, organizar e sistematizar os principais processos e procedimentos da gestão escolar. Inspirado no PDCA1 e adaptado à realidade educacional da escola pública brasileira. 0 Circuito de Gestão é composto pelas etapas de Planejamento, Execução, Monitoramento e Avaliação de Resultados, Reunião de Boas Práticas e Correção de Rotas. Com base nele espera-se que a escola consiga construir, executar e acompanhar um Plano de Ação efetivo, realista e, ao mesmo tempo, transformador, sempre tendo em vista $o$ alcance de metas de aprendizagem estabelecidas pelos estados.

0 estabelecimento de Metas é o ponto de partida para o início do Jovem de Futuro, pois orientará, tanto o planejamento da escola, como o trabalho de acompanhamento do profissional de Apoio ao Circuito de Gestão - ACG. A meta do estado foi definida pela Secretaria de Educação com o auxílio do Instituto Unibanco. Desse modo, o estado de Ceará tem um desafio de alcançar um IDEMédio de 3,75 em 2017 e a Meta da nossa Regional é de 3,79.

Após o conhecimento da Meta individual, a escola, a partir do seu Diagnóstico, elaborou o seu Plano de Ação, pois a principal maneira que o Jovem de Futuro propõe para efetivar a gestão focada em resultados. O Plano de Ação é um importante instrumento para a materialização do planejamento participativo na escola. É por meio dele que a comunidade escolar traça o que é preciso fazer, de acordo com o seu diagnóstico, para alcançar os resultados esperados. Ele é um guia para a execução e serve para que a equipe não perca de vista a melhoria da aprendizagem e o caminho traçado para sua efetivação.

Para construção do Plano de Ação se faz necessário realizar o Planejamento, outra etapa importante, do Circuito de Gestão. Os três passos do Planejamento do Jovem de Futuro são: Levantamento de Causas onde se busca as causas relacionadas ao componente do IDE Médio2 selecionado, o filtro de gerenciamento onde se separa as causas que estão sobre o gerenciamento da escola daquelas que não estão e o Mapa da Ação este define as ações relacionadas às causas que estão sob o gerenciamento da escola. .

Elaborado o Plano de Ação é hora de colocar em prática as ações planejadas, não perdendo de vista o monitoramento de rotina, as adequações e o registro, pois durante a execução das ações se faz necessário o monitoramento diário das tarefas propostas no Plano, como também o registro semanal e coletivo das tarefas realizadas. No que tange à implementação do Circuito de Gestão, em particular, o registro constitui-se em uma matéria-prima para acompanhar todas as etapas, mostrando se a escola está caminhando na direção e tempo pretendidos.

Durante a Execução do Plano de Ação temos a SMAR, Sistemática de Monitoramento e Avaliação dos Resultados, que são reuniões trimestrais que servem para fazer uma análise sobre a execução do Plano de Ação, bem como verificar o alcance dos resultados. Este é o momento de avaliar o andamento dos Processo Cruciais do Circuito de Gestão e de analisar o desempenho no índice de desenvolvimento da Educação Básica IDEB/IDEMédio, dependendo da disponibilidade dos dados.

São etapas do Circuito a Reunião de Boas Práticas (RBP) e a Correção de Rotas (CR).

A Reunião de Boas Práticas é uma atividade trimestral que reúne escolas de uma mesma Regional com o objetivo de se apoiarem na busca por melhores resultados de aprendizagem. É um momento de troca de experiências entre as escolas. As escolas poderão compartilhar os aprendizados relacionados às práticas que: favorecem a execução das tarefas: facilitam a entrega dos produtos; produzem efeitos sobre os resultados pretendidos; promovem a melhoria dos indicadores estruturantes.

A Correção de Rotas é o momento de revisar o caminho e as estratégias traçadas e identificar aquelas que não produziram resultado para alcançar a meta, ou seja, para potencializar a aprendizagem dos estudantes. Após a escolas corrigirem suas rotas retoma o Plano de Ação a partir de sua Meta e novamente se faz um novo percurso em todas as etapas do Circuito, sempre na busca da melhoria da aprendizagem dos seus estudantes. 


\subsection{IMPLEMENTAÇÃO DO CIRCUITO DE GESTÃO NA EEM JOSEFA ALVES BEZERRA}

A implementação do Circuito na escola aconteceu no dia dezessete de abril do corrente ano onde foi realizada a primeira Visita Técnica, Compromisso com as Metas, para apresentação do Circuito de Gestão e da Meta estabelecida por escola. A primeira visita foi uma apresentação para o Núcleo Gestor da Escola, na ocasião foi apresentada a Meta individual que é de 3, 52 e na segunda Visita Técnica o Núcleo Gestor apresentou os tópicos discutidos na Visita anterior para o Grupo Gestor, esse grupo é composto pelo Diretor e Coordenador e representantes de professores, alunos, funcionários e pais. O Grupo Gestor é corresponsável por todas as ações do Circuito de Gestão na Escola.

Foi realizada três Visitas Técnicas de Planejamento, durante o mês de maio e junho, onde foi apresentada a estrutura do Planejamento e do Quadro Situacional da escola.

Refletimos sobre os componentes, causas e ações que interferem diretamente nos resultados de aprendizagem dos alunos. Refletimos sobre os resultados do SPAECE nos três últimos anos e sobre os aspectos que interferem na aprendizagem dos alunos na disciplina de Língua Portuguesa e sobre o problema da Evasão com o controle na infrequência dos alunos.

Verificou-se a consistência do Plano de Ação e a potência do conjunto de ações que impactarão positivamente na causa e no componente do IDE Médio selecionados a partir de reflexões realizadas com o Grupo Gestor.

Durante o mês de agosto realizou-se três Visitas Técnicas da etapa de Execução onde verificamos o andamento das tarefas propostas no Plano de Ação, buscando as evidências do andamento das mesmas, averiguando através dos registros dos formulários entregues nas visitas para o acompanhamento através do balanço semanal das ações realizadas; verificando também o acesso ao Sistema de Gestão de Projetos SGP, para registro do acompanhamento.

Nesse percurso das visitas paralelamente acontecia as ações na escola a mesma realizou em todas as séries do Ensino Médio nos dois turnos manhã e tarde, uma reunião com todos alunos na sala de aula, refletindo sobre suas fortalezas e fragilidades que depois foi condensado e repassado para os líderes de sala, para que eles repassassem para os demais alunos, buscando a corresponsabilização no espaço de sala de aula. 0 maior desafio da escola

durante o percurso da implementação do Circuito de Gestão foi/é mobilizar e envolver os pais nas ações da Escola. A gestão não consegue envolvê-los de maneira efetiva, por isso a infrequência e o abandono são os indicadores que mais preocupam a escola.

A Sistemática de Avaliação de Resultados - SMAR está prevista para o dia dezenove de setembro e a Reunião de Boas Práticas - RBP e Correção de Rotas - CR acontecerá nos meses subsequentes onde estaremos fechando todas as etapas do Circuito de Gestão nas escolas.

\section{RESULTADOS E DISCUSSÕES}

A aplicação do questionário tinha como objetivo verificar se todos os atores da escola tinha conhecimento sobre o Circuito de Gestão e verificar se as ações propostas no Plano de Ação irá contribuir não só para o alcance da Meta estabelecida pela escola como também para melhoria da aprendizagem dos alunos.

A Dupla Gestora aponta que o Circuito de Gestão é "uma ferramenta que permite organizar os processos, as responsabilidades e as atividades da Gestão Escolar". O Circuito contribui para o alcance da Meta "através das ações planejadas e executadas, da avaliação e correção de rotas". Apontam que através do Circuito de Gestão é possível alcançar a Meta "desde o Plano de Ação seja implementado e avaliado, fazendo as correções necessárias ao longo do desenvolvimento de cada ação". Acreditam que o Circuito de Gestão é uma ferramenta importante para a realização de ações na escola "porque ele permite identificar as causas da falta de aprendizagem". Citam as ações que a escola está realizando para melhoria da aprendizagem dos alunos tais como: "atividades voltadas para as disciplinas de Língua Portuguesa e Matemática, oficinas, simulados, gincanas, reuniões com os responsáveis e alunos, chás literários, projetos e reforço escolar". Acredita, que essas ações realmente contribuem para melhoria da aprendizagem dos alunos "desde que sejam realizadas e que o Circuito de Gestão seja segundo, sim".

Quanto aos professores apresentaram seu entendimento sobre o que é Circuito de Gestão que é um "projeto em parceria com o Instituto Unibanco, que usa uma metodologia com ações específicas para problemas que afetam o rendimento e a aprendizagem". 
Indagados sobre, qual a Meta que escola deverá atingir no final do ano letivo de 2017 todos foram unânimes nas suas respostas "atingir a Meta de 3,52 tendo um acréscimo de em 0,27\% em relação a Meta de 2016".

Indagados sobre as ações que a escola está realizando para melhoria da aprendizagem dos alunos, as respostas dos mesmos foram: "Oficinas de Português e Matemática, café literário, saraus poético, rodas de leitura, oficinas de gêneros textuais e simulados voltados para o SPAECE/ENEM". Em se tratando sobre se eles acreditam que essas ações realmente contribuem para melhoria da aprendizagem dos alunos eles responderam: "Sim. Acredito que as ações pedagógicas planejadas e executadas com responsabilidade os resultados serão alcançados”. Dos questionamentos realizados com os alunos sobre o que é Circuito de Gestão, obtivemos os seguintes resultados: três alunos responderem que não sabiam; sete alunos responderam que "e um grupo de pessoas acima dos professores que são responsáveis por grande parte dos projetos da escola" e dois alunos responderam que "é um projeto do Jovem de Futuro que busca promover ações de fortalecimento da aprendizagem na escola". Quanto a Meta que escola deverá atingir no final do ano letivo de 2017 tivemos os seguintes resultados: oito alunos responderam que a mesma é de "3,52"; dois alunos citaram apenas o "salto" que a escola precisa dar em relação ao ano de 2016 que é : "o crescimento de 0,27\%"; um aluno disse que não sabia e três disseram que: "atingir os melhores resultados na aprendizagem dos alunos".

No que se referente as ações que a escola está realizando para melhoria da aprendizagem deles tivemos as seguintes respostas: um aluno disse que não sabia; 02 alunos citaram ações realizadas pela escola tais como: "oficinas; chá literário e o lançamento do Projeto Mais Aprendizagem". Os demais, onze alunos destacaram que a escola busca realizar projetos de interesse e que envolvem os mesmos. Se eles acreditam que essas ações realmente contribuem para melhoria da aprendizagem deles, treze alunos responderam que "Sim", destacando o interesse deles para com a aprendizagem e um aluno disse que não sabia.

Dos questionamentos realizados com os funcionários obtivemos as seguintes respostas sobre o que é Circuito de Gestão: "É um método que ajuda a gestão a concretizar seus resultados a partir de uma meta estabelecida". No que se refere a Meta que escola deverá atingir no final do ano letivo de 2017 os três foram unânimes na resposta apontando "3,52".

Destacaram sobre as ações que a escola está realizando para melhoria da aprendizagem dos alunos: "acompanhamento diário à Infrequência, atividades extraclasse, Chá literário; sarau poético, oficinas de Matemática e envolver os pais na vida escolar do aluno" e que essas ações realmente contribui para melhoria da aprendizagem dos alunos, "pois são ferramentas que contribuem para o empoderamento dos alunos na vida escola".

Diante das análises do acompanhamento as ações realizadas pela escola e dos questionários respondidos pela equipe escolar, podemos observar que o Circuito de Gestão é de conhecimentos de todos, principalmente a Meta da Escola, assim como também as ações citadas por eles na melhoria de seus resultados; embora os alunos tenham dificuldade de definir o método do Circuito de Gestão fica claro que eles estão por dentro do processo e isso fica evidente quando percebemos que as ações citadas pelos mesmos refletem no envolvimento deles e na melhoria de sua aprendizagem. Todos acreditam que o método impactará diretamente no resultado da aprendizagem dos estudantes. Infelizmente a escola não consegue envolver o segmento dos pais nas ações da escola e isso é o maior desafio para melhoria de um dos indicadores que preocupa a escola que é a infrequência.

\section{CONSIDERAÇÕES FINAIS}

Caberá a cada um tentar transformar esse universo de possibilidades, que é o espaço de sala de aula, onde o Plano de Ação é o norteador desse processo. 0 questionário elaborado para a equipe escolar foi importante porque podemos refletir sobre a implementação do método na escola de forma que ele subsidiou a pesquisa ora apresentada.

Diante das análises do acompanhamento as ações realizadas pela escola e dos questionários respondidos pela equipe escolar, podemos verificar que o Circuito de Gestão está caminhando de forma positiva no espaço escolar, embora nem todos os atores tenha apropriação do que realmente é o Circuito e me refiro aos alunos, mas tem ciência de que a escola tem todas suas ações voltadas para a melhoria de seus resultados e eles são conscientes que estão envolvidos no processo para melhoria de sua aprendizagem. 
Só poderemos ter certeza que o método realmente será eficaz no final do ano letivo quando o Plano de Ação terá sido executado na sua totalidade e os resultados internos e externos da escola forem analisados e se constatar que eles se aproximaram ou alcançaram a sua Meta.

\section{REFERÊNCIAS}

[1] Bolívar, A. melhorar os processos e os resultados educativos: o que nos ensina a investigação. Lisboa: Fundação Marques Leão 2012.

[2] Instituto Unibanco. Relatório de Atividades 2003. São Paulo: Instituto Unibanco, 2004

[3] ___ Projeto Jovem de Futuro. Apresentação em PowerPoint. Fortaleza: Instituto Unibanco, 2016.

[4] ___ Projeto Jovem de Futuro. Apresentação em PowerPoint. Fortaleza: Instituto Unibanco, 2017.

[5] ___ Projeto Jovem de Futuro. Circuito de Gestão: princípios e método. Percurso Formativo de Gestão Escolar para Resultados de Aprendizagem. São Paulo: Instituto Unibanco, 2017.

[6] Conheça o Jovem de Futuro uma estratégia de gestão escolar para resultados de aprendizagem. Disponível em: http://jovemdefuturo.org.br/. Acesso em 30/08/2017.

[7] Luck, H. Liderança em gestão escolar (Série Cadernos de Gestão Escolar) 2.ed. Petrópolis: Vozes 2010.

[8] Soares, T. F. A eficácia da gestão escolar no contexto do Projeto Jovem de Futuro. São Paulo: Instituto Unibanco, 2012. 


\section{Capítulo 4}

\section{Conselho de classe: Algumas considerações}

\section{Ronaldo da Silva Correa \\ Vanilda Alves da Silva}

Resumo: A temática é o Conselho de Classe escolar como espaço de discussão, um momento privilegiado que abre oportunidades para discutir e avaliar toda a equipe educacional e a situação do aluno, seu aproveitamento individual e das turmas em geral. É uma reunião de caráter avaliativo, coletivo, em que as pessoas envolvidas no processo de ensino aprendizagem discutem sobre a capacidade cognitiva dos alunos, o desempenho dos docentes, os resultados das estratégias de ensino e outros aspectos referentes a esse processo, buscando alternativas para superação dos problemas educacionais presentes na comunidade escolar. Na maioria das escolas, porém, o conselho de classe é visto como uma reunião em que o foco principal são os alunos, haja vista que se discute o desempenho deles, ou seja, as notas ou conceitos atingidos, e, ainda, a questão comportamental desses alunos. Este trabalho tem por objetivo refletir e avaliar sobre algumas considerações e a finalidade do Conselho de Classe como prática pedagógico-educativa, além de diagnosticar o trabalho coletivo entre professores, coordenadores pedagógicos e alunos.

Palavras-Chave: Conselho de Classe, Espaço de Discussão, Prática Educativa, Desempenho. 


\section{INTRODUÇÃO}

O Conselho de Classe, do modo como é realizado na maioria das escolas, restringe-se apenas a avaliar o desempenho individual do aluno e da turma em sua totalidade. Este trabalho traz uma reflexão sobre a prática educativa e avaliação do trabalho individual e coletivo de professores e coordenadores pedagógicos com os alunos e como estão conduzindo essa prática educativa. Sob este ponto de vista, a intenção é proporcionar a reflexão sobre o trabalho que vem sendo realizado e propor novas estratégias pedagógicas embasadas nas teorias de alguns estudiosos e adequá-las à realidade escolar, na tentativa de modificar essa prática para obter resultados que incidam diretamente sobre o estudante de forma positiva e, possivelmente, promover a mudança em algumas práticas docente.

Durante a participação no Conselho de Classe, observando um enfoque voltado para a aprovação ou reprovação do aluno nas disciplinas em que ele não conseguiu atingir a meta, surgiu o interesse pelo tema, no sentido de trazer um aprofundamento teórico e conhecer a sua origem e finalidade de acordo com os estudiosos. Diante do ponto de vista manifestado por professores e coordenadores pedagógicos no Conselho de Classe, este tema precisa ser fundamentado para que todos entendam e façam uma avaliação a fim de refletir sobre suas práticas pedagógicas e, principalmente, trazer o estudante para esse espaço uma vez que ele é o foco das discussões.

\section{METODOLOGIA}

Este trabalho apresenta um estudo sobre o Conselho de Classe Escolar à luz de teóricos que tratam esse tema, demonstrando suas reais funções e características no âmbito escolar. Trata-se de uma pesquisa bibliográfica com base em periódicos científicos brasileiros publicados na biblioteca eletrônica Scientific Electronic Library Online - Scielo. A indicação desse tipo de pesquisa relaciona-se ao fato de a aproximação com o objeto se dar a partir de fontes bibliográficas. Gil (2002, p.44) corrobora da mesma ideia ao afirmar que, pesquisa bibliográfica ..."é desenvolvida com base em material já elaborado, constituído principalmente de livros e artigos científicos".

O produto da revisão bibliográfica revelou que, apesar de a literatura sobre Conselho de Classe ser escassa e ainda não ter obtido destaque diante de teóricos que tratam de assuntos educacionais, o material encontrado foi primordial para entendermos a finalidade dessa prática educativa. De acordo com as pesquisas realizadas, foi possível obter fundamentos que possibilitam que o docente reavalie a prática do conselho de classe e perceba seu papel e sua importância.

\section{CONSELHO DE CLASSE: ALGUMAS CONSIDERAÇÕES}

Para compreendermos o que é o Conselho de Classe e quais as suas finalidades faz-se necessário o conhecimento da história desse órgão colegiado de gestão. Nesse sentido, os fatos históricos apontam que surgiu na França, por volta de 1945, pela necessidade de realização de um trabalho interdisciplinar a fim de avaliar o aluno de forma coletiva. Dalben (2004, p. 22) afirma que

[...] Por ocasião da reforma de ensino francesa de 1959, foram instituídos três tipos de conselhos; o Conselho de Classe, no âmbito da turma; o Conselho de Orientação; no âmbito do estabelecimento; e o Conselho Departamental de Orientação, em esfera mais ampla. Essa forma almejava declaradamente organizar um sistema escolar fundado na Observação sistemática e contínua dos alunos, com vista a oferecer, a cada um, o ensino que corresponda a seus gostos e aptidões.

O Conselho de Classe francês tinha a finalidade de encaminhar e distribuir o aluno no sistema dualista implantado na França naquela época. Orientava os alunos às diversas modalidades de ensino de acordo com as "aptidões" e "caráter" demonstrados pelos mesmos. 
Esse modelo de Conselho de Classe foi trazido ao Brasil por estagiários, em 1958, e foi levado ao Colégio de Aplicação da Universidade Federal do Rio de Janeiro (CAP). Inicialmente, no Brasil, foi implantado voluntariamente e, posteriormente, por meio de portarias e deliberações. Com referência ao conceito de Conselho de Classe e sua finalidade, Rocha (1984, p. 9) considera:

O Conselho de Classe é uma reunião dos professores da turma com múltiplos objetivos, entre outros destacamos: avaliar o aproveitamento dos alunos e da turma como um todo; chegar a um conhecimento mais profundo do aluno e promover a integração dos professores e dos outros elementos da equipe da escola.

Podemos observar que essa prática pedagógica é uma ação conjunta e colaborativa dos integrantes da escola nesse espaço avaliativo denominado Conselho de Classe. Possivelmente o magistério é uma das profissões que mais reúne pessoas das mais variadas classes sociais, personalidades e culturas diferentes para adquirir conhecimentos transmitidos por determinados profissionais dessa área. O Conselho de Classe, nesse aspecto, é de grande importância, porque reúne todas essas informações e colabora para que as mudanças necessárias aconteçam tanto na prática pedagógica quanto na situação escolar do educando. Essas reuniões que acontecem na comunidade escolar devem ser entendidas como fonte de conhecimentos que auxiliarão o professor na compreensão do processo de aprendizagem e identificar seus problemas.

Cruz (1995, p. 117) faz uma aproximação do conceito de avaliação ao conceito de conselho: "Assim, o conselho de classe é o momento de uma avaliação diagnóstica da ação pedagógica - educativa feita pelos professores e alunos (em momentos distintos, às vezes) à luz do Marco Operativo da Escola". De acordo com esse autor, existem dois momentos de muita importância no Conselho de Classe.

0 primeiro é a avaliação diagnóstica do trabalho realizado em coletivo a partir de um referencial. 0 segundo deve beneficiar as ações e o Projeto Político Pedagógico no qual estão descritos os objetivos que se pretende alcançar no ano letivo. Assim, verificamos que é uma reflexão conjunta da ação pedagógica na vida escolar. 0 Conselho de Classe torna-se um espaço de reflexão pedagógica em que a comunidade escolar situa-se conscientemente no processo, com a função de reorientar a ação pedagógica de acordo com os fatos apresentados e metas previstas no Plano Político Pedagógico Escolar.

Nesse sentido, conforme aponta Penin (1992, p, 90), esse processo "Não está nas possibilidades da escola mudar as características de vida dos alunos ou de suas famílias, mas, a escola pode e deve mudar as formas e condições do serviço prestado, conforme as características dos alunos". Diante das funções que a escola apresenta, cabe a ela buscar formas de inovação, após a reflexão sobre o papel do conselho de classe. Para isso é necessário que, diante de tantas modificações atuais, façamos um acompanhamento de forma reflexiva e participativa, visando modelar a estruturação do Conselho de Classe, hoje, nas escolas.

No âmbito escolar, é de fundamental importância que essa prática pedagógica seja observada como fonte de busca de alternativas para a progressão em relação aos problemas pedagógicos, comunitários e administrativos, contando com a participação de todos os envolvidos no processo de avaliação do ensinoaprendizagem, formando juntos novas propostas para que a escola tenha êxito no seu contexto social. Para Dalben (2004, p. 31),

O Conselho de Classe é um órgão colegiado, presente na organização escolar, em que vários professores das diversas disciplinas, juntamente com os coordenadores pedagógicos, ou mesmo os supervisores e orientadores educacionais, reúnem-se para refletir e avaliar o desempenho pedagógico dos alunos das diversas turmas, séries ou ciclos.

Mediante os estudos realizados e as leituras reflexivas sobre o Conselho de Classe observamos a grandeza de sua ação, que é avaliar. Avaliar o professor, o aluno e a escola como um todo. Dessa forma, o Conselho de Classe representa um momento privilegiado e abre oportunidades para discutir e avaliar toda a equipe educacional e a situação do aluno naquele espaço. Segundo Libâneo (2004, p. 303), Conselho de Classe

[...] é um órgão colegiado composto pelos professores da classe, por representantes dos alunos e em alguns casos, dos pais. É a instância que permite acompanhamento mais minucioso da turma e de cada um e análise do desempenho do professor com base nos resultados alcançados. Tem a responsabilidade de formular propostas referentes á ação educativa, facilitar e ampliar as relações mútuas entre os professores, pais e alunos, e incentivar projetos de investigação. 
Dalben (1996) e Rocha (1984) compartilham da mesma ideia de Libâneo (2004), que concebe o Conselho de Classe por meio de um olhar cuidadoso para a sensatez que esse órgão colegiado tem de criar propostas educativas que possam garantir uma relação benéfica entre alunos, professores e pais. Vale ressaltar que para esses teóricos esse órgão colegiado é aquele em que há representações diversas e as decisões são tomadas em grupo, com o aproveitamento de experiências diferenciadas. Todos têm o direito de participação e cada integrante pode contribuir por meio do seu ponto de vista, na análise, reflexão e avaliação do processo de ensino-aprendizagem em sala de aula, do trabalho que é realizado pelo professor e do desempenho do educando.

É importante lembrar que nem sempre o aluno se faz presente nessa prática pedagógica, mas que ele é o foco principal nesse momento de avaliações e reflexões. É sobre ele que serão feitos apontamentos, pelo professor, referentes ao seu desempenho. Por meio dos resultados negativos e positivos avalia-se, também, o trabalho do professor, como mediador do conhecimento e, em geral, o trabalho da escola.

Nesse contexto, Rocha (1984, p. 28) afirma que “O grande potencial educativo do Conselho de Classe está no fato de constituir, dentro do processo educacional, o principal instrumento a ser utilizado para atingir uma maior participação dos professores". Nesse aspecto de integração, percebe-se que a participação do professor durante o Conselho de Classe é relevante, uma vez que suas ideias são confrontadas e se discutem os problemas pertinentes em relação ao trabalho realizado na sala de aula.

A participação efetiva dos envolvidos no processo educacional é muito importante tanto por razões didáticas, quanto por razões de melhoria, como um todo do espaço escolar. Dalben (2006) apresenta algumas preocupações que devem estar presentes na organização do Conselho de Classe enquanto órgão deliberativo, dentre elas,

[...] a) objetivos de ensino a serem alcançados; b) uso de metodologias e estratégias de ensino; c) critérios de seleção de conteúdos curriculares; d) projetos coletivos de ensino e atividades; e) formas, critérios e instrumentos de avaliação utilizados para o conhecimento do aluno; f) formas de acompanhamento dos alunos e em seu percurso nos ciclos; g) critérios para apreciação dos alunos ao final dos ciclos; h) elaboração de fichas de registro do desempenho do aluno para o acompanhamento no decorrer dos ciclos e para informação aos pais; i) formas de relacionamento com a família; j) propostas curriculares alternativas para os alunos com dificuldades específicas; l) adaptações curriculares para alunos portadores de necessidades educativas especiais; m) propostas de organização dos estudos complementares. (Dalben, 2006, p.33)

Nesse sentido, o Conselho de Classe não começa e termina no mesmo dia, deve existir um acompanhamento anterior e posterior em que os professores e coordenadores pedagógicos avaliam o planejamento, selecionam os conteúdos e preparam uma nova metodologia para estimular o desenvolvimento intelectual do estudante.

\section{0 CONSELHO DE CLASSE ATUALMENTE NAS ESCOLAS}

Analisando o que realmente é o Conselho de Classe com base nos estudos realizados, verificamos que, na maioria das escolas, ele funciona como um espaço cujo foco são as notas e o comportamento dos discentes; não são avaliadas as práticas pedagógicas em sala de aula. Participando de um Conselho de Classe em uma escola da rede pública estadual, verificamos que o foco principal da reunião é o rendimento e a disciplina do aluno no âmbito escolar, e que a equipe para a reunião é composta do Diretor e Vice-Diretor, professores e coordenadores pedagógicos. Os diretores passam as primeiras orientações de como vai acontecer o Conselho de Classe e define a ordem em que as turmas serão avaliadas. A orientação é que os professores informem as médias dos alunos em sequência de disciplinas, confiram as notas, façam anotações dos alunos que não atingiram a média e relatem sobre o comportamento deles em sala de aula. A discussão entre professores e coordenadores pedagógicos gira, assim, em termos de aprovação ou reprovação dos alunos, com base no que foi informado e relatado sobre cada um deles.

Existe o caso em que o estudante permanece ocioso durante todo o período de aula sem apresentar o mínimo possível de produção nas respectivas disciplinas, porém, apresenta capacidades cognitivas suficientes para que os professores conselheiros o considerem apto a frequentar uma nova série no ano seguinte. 
Dessa forma, os estudantes que não tenham atingido nota necessária para aprovação, que, entretanto possuam essas capacidades intelectuais e um bom comportamento, podem ser considerados aprovados, em ata, e com o consentimento de todos os professores participantes do Conselho, desde que não tenham sido aprovados, no ano anterior, por meio de critério idêntico.

Com base nessa experiência vivenciada nesse momento tão importante de avaliação, observamos que, em momento algum, a reunião foi redirecionada para que outros aspectos fossem analisados, como objetivo de ensino, metodologias, estratégias, forma de relacionamento familiar, novas propostas curriculares entre outras.

\section{CONSIDERAÇÕES FINAIS}

Os Conselhos de Classe somente cumpririam sua efetiva função se constituíssem meios pelos quais os professores repensassem suas práticas pedagógicas para cada etapa do trabalho realizado, e não como uma ferramenta para classificar alunos de acordo com suas notas e comportamento na escola. A partir desse aspecto e da experiência de participação em uma reunião de Conselho de Classe percebemos a necessidade de que essa prática educativa seja repensada em relação aos aspectos pedagógicos diversos, e não apenas disciplinar.

De acordo com os autores que estudam essa temática, percebemos que o Conselho de Classe é um momento de avaliar o trabalho individual e coletivo de todos que estão envolvidos no processo de aprendizagem.

A pesquisa foi fundamental para aproximar teoria da prática, e ainda levou a refletir sobre o real papel do Conselho de Classe. Esperamos que uma visão atual de Conselho de Classe seja implantada nas escolas; para que isso aconteça, é necessário que professores, coordenadores e direção da escola reflitam juntos sobre as práticas pedagógicas, procurando promover mudanças na realização desse momento escolar, no sentido de propiciar novas expectativas e resultados em relação ao trabalho do professor e de propiciar um bom aprendizado dos alunos.

\section{REFERÊNCIAS}

[1] Cruz, Carlos H. C. Conselho de Classe e participação. Revista de Educação AEC. Brasília, DF: AEC do Brasil, nº. 94, jan./mar 1995, p. $11-136$.

[2] Dalben, Ângela Imaculada Loureiro de Freitas. Trabalho escolar e conselho de classe. 4. ed. Campinas: Papirus, 1996. (Coleção magistério: formação e trabalho pedagógico).

[3] Conselho de Classe e avaliação - perspectivas na gestão pedagógica da escola 3. ed. Campinas: Papirus, 2006. (Coleção magistério: formação e trabalho pedagógico).

[4] Gil, Antonio Carlos. Como elaborar projetos de pesquisa. 4. ed. São Paulo: Atlas, 2002

[5] Libâneo, José Carlos. Organização e gestão da escola: teoria e prática. 5. ed. Revista ampliada - Goiânia: Alternativa, 2004.

[6] Penin, Sônia T. S. Educação Básica a Construção do Sucesso Escolar. Em Aberto, Brasília, no․ 53, 1992.

[7] Rocha, Any Dutra Coelho da. Conselho de Classe: burocratização ou participação. Rio de Janeiro: F. Alves, 1984. 


\section{Capítulo 5}

Um breve comentário do processo e a evolução da educação superior vinculado nas universidades, empresas e governo

\section{Rodrigo Leme Dias de Souza}

Resumo: Onde estamos e onde vamos com a nova proposta dos governos na evolução educacional dos países da América Latina? 0 que sabemos até agora é que os egressos estão cada vez mais avançados na educação do nível de graduação à doutorado. 0 objetivo desta pesquisa é demonstrar a evolução deste comportamento educacional e social; onde a educação na década de 50, os indivíduos pensavam na evolução de graduação para ocupar cargos de status nas companhias. Se observa ainda, que a produção de pesquisas com publicações nas Universidades, nem todas são reconhecidas no Brasil pela CAPES - Coordenação de Aperfeiçoamento de Pessoal de Nível Superior, e o discente que possui publicação qualificado pela CAPES, acaba obtendo um emprego com maior qualificação, e que não estão desempregados, e sim; contribuindo pela sociedade, com a pesquisa de tecnologia e inovação nas empresas. Além destas informações, demonstraremos em percentual entre os países da América Latina: Argentina, Brasil e México, quantos egressos de graduação chegam ao doutorado, bem como estes profissionais que estão com cargos ocupados nas universidades se estão atuando profissionalmente em tempo integral ou parcial como docentes. Essa pesquisa é de caráter exploratória e explicativa quanto aos objetivos e técnicas, traz pesquisas bibliográficas, pesquisas documentais, sites e artigos científicos. Expõe dados comportamentais dos egressos bem como a sua produção de teses e dissertações.

Palavras-chave: Sociedade. Educação e Instituição Educativa. Mercado de Trabalho. Desenvolvimento Econômico. Empresa. 


\section{INTRODUÇÃO}

No passado, o nível de escolaridade para a obtenção de um emprego não havia muita exigência de educação superior nas empresas, e aqueles que detinha a educação superior possuía uma posição social melhor na empresa. Neste artigo, pretendemos debater as dificuldades que os jovens têm encontrado no mercado de trabalho, pós formação acadêmica com a vinculação dos investimentos entre as Universidades, Empresas e Governo para o desenvolvimento de pesquisas e atuação no mercado de trabalho. Destacamos ainda, como um fenômeno em todos os seguimentos de mercado, em todos os países, principalmente na América Latina; pois esse comportamento, é devido as mudanças que estão acontecendo neste século, que cada vez mais veloz, concomitante com a maximização da competividade, inovação e evolução da tecnologia. E para aquele leitor que possa se interessar e aprofundar-se seus conhecimentos, deve consultar os seguintes autores: Lamarra e Centeno (2011), Clark (1987), Gould (2002), Gazzola e Didriksson (2008), Lamarra e Cappola (2013), Capes (2017), Quispe, Victorino e Atriano (2014), Rivera, Ocampo e Arredondo (2011), que relata sobre o comportamento do indivíduo que estão inseridos nas Universidades e posteriormente, como estão atuando no mercado de trabalho.

Na década de 50 a educação representava uma possibilidade de atuação dos indivíduos, para um crescimento profissional e uma posição privilegiada na hierarquia das empresas. Para Lamarra e Centeno (2011), comenta que a profissão acadêmica tem sido estudada; deste a perspectiva sociológica, das normas epistemológicas, as relações entre a academia e o governo, e entre eles, há uma parceria de investimento.

Nos últimos anos, a profissão acadêmica tem se desenvolvido e contribuindo na melhoria de suas pesquisas voltadas para as empresas. Devido à importância do setor acadêmico, se iniciou um desenvolvimento social e econômico, que se configurava a profissão de pesquisador, como um acesso de informação, promoção e estabilidade, com uma conexão com os demais seguimentos sociais Clarck (1987).

Já para Gould (2002), relata que há uma relação entre os processos integrais da docência, com a investigação e extensão da cultura da Instituição de Ensino Superior com o socioeconômico. Ainda, complementa com a seguinte citação:

“... o conjunto de normas, planos, regulamentos, recursos atividades administrativas, assim como ações e projetos, mediante os quais as Instituições de Ensino superior levam ao início, de maneira sistemática e coordenada, mas não burocratizada, suas relações com os setores, públicos, social e produtivo, os recursos são os insumos do sistema, as atividades administrativos-operativos transformam os insumos em resultados... ações e projetos de vinculação são cumpridos em tempo e forma, conforme seus plano e critérios de qualidade (Gould, 2002, p.35).

O Ensino Superior na profissão universitária na América Latina, em sua grande maioria governamental passou uma modificação no processo de massificação, a qual surgiu várias Instituições de Ensino Superior de iniciativa privada com nível heterogêneo de qualidade. Todos os países tiveram o processo de regulação, como no caso do Brasil, que tivemos o órgão chamado Ministério da Educação, para assegurar a qualidade no ensino superior.

Mesmo após a proliferação das universidades privadas na América Latina, muitas das quais configuraram uma profissão acadêmica e profissional com características diferenciadas, foram negativas. Um dos pontos foram a falta de participação das empresas privadas nas Instituições de Ensino Superior. Sendo que os egressos acadêmicos saem da instituição de ensino com baixo conhecimento técnico empresarial. Um outro ponto negativo é o sistema de seleção dos alunos na entrada nas universidades, chamada de "vestibular", a qual muitas delas desenvolvem uma promoção salarial dos alunos, para obter a IES este futuro discente, para que possa obter o menor indice de inadimplência das receitas da prestação de serviços.

E por último, temos a nova tendência tecnológica utilizado nas Universidades Privadas, que é o uso das aulas por conferência. Este processo de globalização foi recebido como uma ameaça nas Instituições de Ensino Superior na América Latina, por também obter um ensino heterogêneos com mais ou menos qualidade comparada com as demais Universidades Privadas, que realizam aulas presenciais.

Nem por isso, foi uma forma de restringir os alunos nas Instituições de Ensino Superior. Segundo Gazzola e Didriksson (2008), comenta que $60 \%$ da efetividade das matrículas na educação superior na América Latina e no Caribe se encontra nos seguintes países: Brasil (28\%), México (17\%) y Argentina (14\%). E 
seguem a ordem por importância: Peru (6\%), América Central (6\%), Chile (4\%), Bolívia (2\%), Caribe $(1 \%)$.

Segundo Lamarra e Cappola (2013), o projeto CAP, que apresenta dados de três países da América Latina: Argentina, Brasil e México no ano de 2009, demonstra em percentual, com objetivo de apresentar se os alunos com formação de graduação, deram sequência educacional, como por exemplo: mestrado e doutorado, de uma perspectiva geral na situação na profissão. Diante do quadro abaixo, termos a saber:

Tabela 1 - Percentual Total

\begin{tabular}{|c|c|c|c|}
\hline \multicolumn{2}{|c|}{ Argentina } & 100 & México \\
\hline Graduação & 100 & 86 & 72 \\
\hline Mestrado & 35 & 58 & 24 \\
\hline Doutorado & 37 & 5 & \\
\hline
\end{tabular}

Fonte: Projeto CAP, 2009

Nesta primeira etapa de interpretação, visualizamos que os brasileiros possuem a maior taxa em percentual dos graduados que dão andamento na educação, como descrito o Mestrado, porém esse percentual, quando é analisado do Mestrado para o Doutorado, esse percentual não há uma evolução, o percentual cai.

O país com menor evolução a Educação do nível de Doutorado entre os três países, apresentada na amostragem é o México, porém com relação ao mestrado, o México se encontra na segundo posição, mas a sua evolução deixa a desejar quando se trata ao nível de doutorado, que perde posição a evolução da continuidade da pesquisa no doutorado.

Dos profissionais da educação, na realidade em algumas universidades não há contratação por tempo integral, e sim de jornada parcial de trabalho. Essa situação usual, é típico na América Latina, por conta dos seus vencimentos salariais são baixos. Esse profissional da Educação começa a procurar oportunidades externas "fora da docência" e ter uma segunda atividade profissional formal ou autônoma. Partindo do pressuposto do quadro anterior, a CAP levantou daquele percentual quantos profissionais da educação trabalham nas Instituições do Ensino Superior de tempo integral ou parcial, e temos a saber:

Tabela 2 - Distribuição em percentuais dos docentes segundo o tipo de dedicação:

\begin{tabular}{|c|c|c|c|}
\hline & Argentina & Brasil & México \\
\hline Tempo Integral & 51 & 55 & 11 \\
\hline Tempo Parcial & 43 & 12 & 0 \\
\hline Tempo Parcial com Contrato & 6 & 33 & 100 \\
\hline TOTAL & 100 & 100 & 100 \\
\hline
\end{tabular}

Fonte: Projeto CAP, 2009

Na Argentina, temos a saber que o percentual de dedicação é muito baixo com relação a tempo integral comparado com outros países, e o que chama a atenção é o tempo parcial e o tempo parcial com contrato no Brasil, que temos profissionais da docência com atividades extra docência, ou seja; possuindo mais de uma atividade profissional.

Os dados ilustrados no quadro acima, demonstra que o Brasil, além de obterem os profissionais da educação, os docentes possuem mais de uma atividades profissional, o órgão de fiscalização do governo do Ministério da Educação, a CAPES - Coordenação de Aperfeiçoamento de Pessoal de Nível Superior, da Diretoria de Avaliação - realiza a cada quadriênio uma avaliação nas Instituições de Ensino Brasileiras, e o último ano realizado, foi em 2017, um dos parâmetros realizados, foi a evolução de produção cientifica 
registrada na CAPES com "QUALIS A1, A2 e B1, do ano de 2004 a 2017 com relação a evolução de Mestrado Acadêmico (ME), Mestrado Profissional (MP) e Doutorados, e temos o seguinte quadro:

Gráfico 1 - Evolução de Produção com Qualis A1, A2 e B1

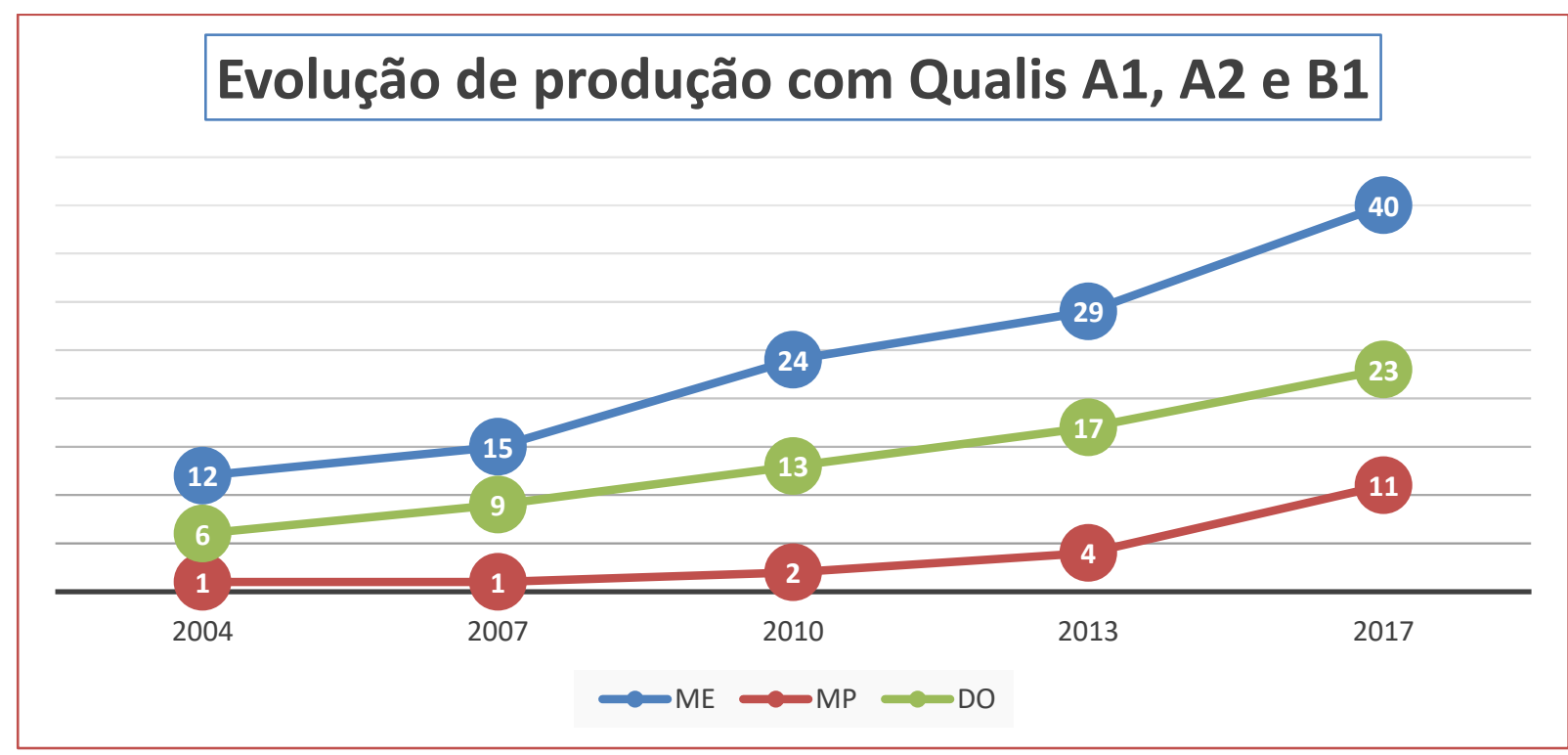

Fonte: CAPES , 2017. Adaptado pelo autor

0 resultado demonstra que o Mestrado Profissional voltado para as empresas ocorreu uma evolução de 36,36\% na produção aprovado pela CAPES nos de 2013 a 2017, essa tendência poderá elucidar que no futuro as empresas poderão investir mais no Ensino Superior. Por consequência o Mestrado e Doutorando também obteve produção qualificados pela CAPES positivamente.

Com relação ao número de titulações, de Doutorado, Mestrado Acadêmico e Mestrado Profissional obtemos através da pesquisa um crescimento considerado com relação ao último quadrimestre conforme os dados da CAPES, alcançando um crescimento de 75\% em relação ao período anterior.

Gráfico 2 - Evolução de Titulações

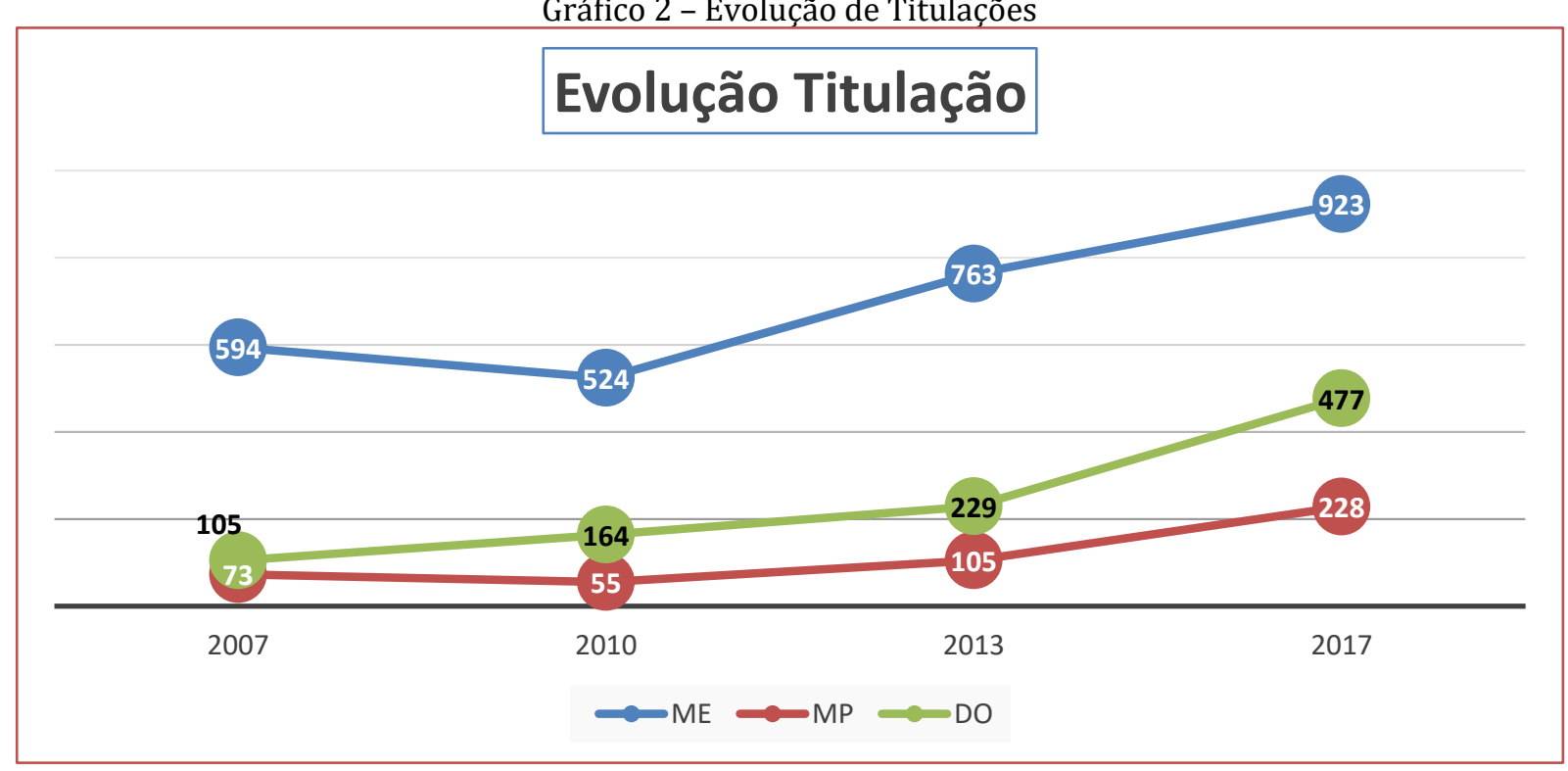


Esse incremento de docentes com elaboração das Teses, indica um avanço na taxa de titulação, que poderia ser um dado que os programas estão sendo atendidos pelo mercado educacional, com a titulação. E com relação a titulação e empregabilidade, o departamento do Centro de Gestão e Estudos Estratégicos, em conjunto com o órgão governamental do Ministério do Trabalho, avaliou a empregabilidade de cada quadriênio e chegou a conclusão que os doutores são reconhecidos na formação de profissionais de pósgraduação estão empregados.

Segundo os dados da CAPES (2017), que a expansão na produção científica qualificada está correlacionada que os profissionais doutores estão empregados, sendo ainda que; o número de matriculados no Brasil são baixos.

Neste processo, há uma correlação de vinculação entre os três eixos: Instituição de Ensino, Empresas e Governo. Mesmo ainda não difundida nas pesquisas universitárias, onde obtemos somente aplicação de recursos financeiros nas Universidade Governamentais, ainda há pouco o investimento das Empresas nas Universidades. Mesmo com passos lentos na evolução educacional o processo é harmônico para o desenvolvimento nas pesquisas. Segundo, Quispe, Victorino e Atriano (2014), que define Universidade, Empresa e Governo com triple hélice, como uma chave de condições de inovação de conhecimento, vejamos neste caso, que há uma convergência nas soluções de problemas específicos nas empresas, e o que falta é o investimento no ensino.

Provavelmente as políticas públicas tem o seu papel de regulamentar as universidades, porém os resultados não são tão satisfatórios para o desenvolvimento das pesquisas. 0 que observamos é que a quantidade de ingressos nas universidades de modo geral é massificada. Porém nem todos consegue finalizar os estudos. De acordo com Rivera, Ocampo e Arredondo (2011), a Universidade Autônoma de Baixa Califórnia, onde há o desenvolvimento de pesquisas entre os investigadores e acadêmicos que participam de vários processos produtivos e que contém o apoio do governo federal, do programa tecnologia e inovação, acredita no triple hélice como um fortalecimento da estrutura educativa.

\section{CONCLUSÃO}

Em neste contexto, demarcado pela complexidade das propostas governamentais, observamos que há mais alunos no ensino superior, ou seja, nas universidades; sejam públicas ou privadas. Destacamos ainda que independentemente do nível de qualidade os países Argentina e Brasil temos o maio número em percentual de matriculados. Enquanto o México chega a 95\% de matriculados, perdendo posição os dois países. E que os há um avanço significante com relação as publicações científicas, sejam elas teses e dissertações. E aqueles profissionais que realizam as publicações estão atuando no mercado de trabalho, na atividade de docência ou empregados numa posição em alguma companhia. Dentro do programa de docência, se observa uma deficiência de empregabilidade por tempo integral na atividade de docência, de fato ocorre que os indivíduos que possui o Mestrado ou Doutorado não trabalham com regime integral nas Universidades, que posteriormente tem uma atividade extra para complementar a renda familiar.

Essa tendência atual é um desenvolvimento da evolução social, onde as Universidades, Empresas e Governo, estão de adaptando para uma nova realidade, e que muitos países estão se adaptando com cortes de recursos governamentais nas universidades e aguardando uma posição das empresas a investirem no Ensino Superior. Para o futuro teremos novas normas que permitam avançar o desenvolvimento das pesquisas cientificas, e que servirá como um método de comparabilidade ou equivalente para mensurar os levantados para qualificar as competências dos futuros profissionais da educação.

\section{REFERENNCIAS}

[1] Gerónimo Bautista, E. (2007). La importancia de la vinculación universidad-empresa-gobierno en México. Revista Iberoamericano para la Investigación y en Desarrollo Educativo. Universidade de Guadalajara.

[2] CLARK, B. The academic life: small words, different words. Princeton: Carnegie Foundation for Advanced of Teaching. 1987.

[3] Gazzola, A. L. y Didrikssom, A. (ed.) (2008) Tendencias de la Educación Superior en América Latina y el Caribe - Caracas> IESALC-UNESCO

[4] Gould, G. (2002). La administración de la vinculación: cómo hacer qué. Obtenido de Secretaría de Educación Pública: http://basica.sep.gob.mx/pec/pdf/dprograma/AdmonVinculacionTOMO\%20II.pdf 
[5] Fernández Lamarra, N. e Perez Centeno, Cristian. (2011). La profesión académica universitaria en América Latina, en perspectiva comparada.

[6] Fernándes Lamarra, N. y Coppola, N. (2013). Desafíos para la construcción del espacio latinoamericano de educación superior, en el marco de las políticas supranacionales, JOURNAL OF SUPRANACITIONAL POLICIES OF EDUCATION, nํㅜ 1, pp. 67-82.

[7] Quispe, L. A., Victorino, R. L., \& Atriano, M. R. (2014). Vinculación de Instituciones de Educación Agrícola Superior (ieas) con sectores productivos. El caso de la residencia profesional en el Instituto Tecnológico del Altiplano de Tlaxcala (ITAT). Revista de la Educación Superior, ANUIES Vol. XLIII (2); No.170, abril - junio. ISNN: 0185-2760, pp135-152

[8] Rivera, I., Ocampo, J., \& Arredondo, L. (2011). El modelo de la triple hélice y la gestión de la vinculación en la Universidad Autónoma de Baja California, México. Universidad Autónoma de Baja Califórnia, p.12

[9] Santos, A. L. M., Villa, R.A.D., \& Beirão, A.P., (2017) Relatório da Avaliação Quadrienal 2017: Ciência Política e Relações Internacionais. CAPES. Brasil: Governo Federal. 


\section{Capítulo 6}

\section{A abertura do espaço escolar}

\section{Dalton Bertini Ruas}

Resumo: Este artigo desenvolve questões relativas ao espaço e educação na conformação das escolas públicas de Ensino Fundamental I. Objetiva-se compreender o modo pelo qual as distintas formas de organização espacial existentes influem nas relações de ensino e aprendizagem. Para alcançar este propósito, confrontaram-se as graduações de abertura espaciais dos agentes do ensino escolar, em particular: a ação dos docentes, os discentes e o suporte material acessível. Mesmo sob uma lei comum de diretrizes e bases da educação nacional, foram encontradas distintas configurações espaciais de escolas públicas com ação interna na Região Sudeste, que neste artigo foram agrupadas por tipologias, de acordo com aspectos morfológicos encontrados. A abordagem é justificada pela pesquisa de Escolano (2001), que identifica o espaço não como um elemento neutro submetido às ações de ensino e aprendizagem, mas como agente curricular oculto da escola. A outra premissa teórica da pesquisa é o conceito de distância social desenvolvido por Hall (2010), que classifica interações sociais segundo determinadas distâncias espaciais. Os casos escolhidos permitem analisar as graduações de abertura da arquitetura escolar na concepção dos espaços da sala de aula e seus limites imediatos, a partir das diferentes possibilidades de interação entre docentes, discentes e o suporte material disponível. Comparando-se as tipologias, encontra-se uma gradual abertura do espaço da sala de aula, cujos indícios refletem uma possível flexibilização do espaço de ensino e aprendizagem, assim como uma menor fragmentação do espaço. A flexibilidade teria como contrapartida uma maior exigência de integração entre os docentes, discentes e o suporte material acessível, impondo a realização do diálogo e do planejamento comum para que seja efetiva.

Palavras-chave: Abertura. Escolas públicas. Ensino fundamental I. Espaço. Tipologias 


\section{INTRODUÇÃO}

Este artigo fez parte de uma pesquisa de Doutorado em Arquitetura e Urbanismo, cujo objetivo geral proposto foi de problematizar para melhor compreender as relações e influências da organização do espaço escolar no âmbito do ensino e aprendizagem. De modo a exemplificar as questões teóricas abordadas, foram classificadas algumas escolas segundo modelos de organização espacial que são distintos, apesar de uma expectativa inicial de uniformidade tipológica sugeridas pelo compartilhamento de uma cultura escolar próxima: uma mesma LDB, período escolar - Fundamental I do ensino público; época - final do século XX e início do XXI; e território - a região sudeste. Foram extraídos e agrupados alguns conceitos cuja origem remete a modos de apropriações do espaço de ensino e aprendizagem de modo que, sem o propósito de abarcar toda a diversidade existente, identificaram-se pelo menos quatro organizações morfológicas do espaço escolar.

Como ressalva à diversidade de agentes alheios à questão do espaço passíveis de diluir a importância deste junto à ação de ensino e aprendizagem escolar, a abordagem da pesquisa pautou-se na teoria da "forma escolar" (LAHIRE; THIN; VINCENT, 2001) como a melhor aproximação para se compreender a inter-relação destes componentes. Segundo estes autores, a escola surge como um espaço específico de ensino, em um determinado tempo, com saberes objetivados e acumulados pela escrita, sendo organizados institucionalmente pelo Estado. A estruturação destes parâmetros identifica a posição e importância do espaço perante outras determinações nas relações de ensino e aprendizagem, situando-as não como estáticas umas com as outras, mas passíveis de conflitos e mudanças. Assim, nesta pesquisa, a abrangência destas questões incorrerá nestes e em outros campos do conhecimento desde que haja implicações espaciais, relacionadas com a gênese da forma escolar.

A preocupação com o espaço da escola, apesar de secundária e menos legítima de discussão para alguns autores, é justificada nesta pesquisa pelo seu papel ativo e revelador de discursos implícitos na forma escolar. Segundo Escolano (2001, p.26):

o espaço escolar tem de ser analisado como um constructo cultural que expressa e reflete, para além de sua materialidade, determinados discursos. No quadro das modernas teorias da percepção, o espaço escolar é, além disso, um mediador cultural em relação à gênese e formação dos primeiros esquemas cognitivos e motores, ou seja, um elemento significativo do currículo, uma fonte de experiência e aprendizagem.

Portanto, as análises destas escolas pretendem desvelar o "currículo oculto" (idem, pg. 26) do espaço, dificilmente apreensíveis e conscientes para os próprios usuários como pelos agentes atuantes. 0 espaço da arquitetura escolar apresenta uma série de possibilidades formativas, que ao contrário de serem objetivas e transparentes, exigem pesquisa e discussão para se constituírem como conhecimento. Uma das motivações principais desta pesquisa é desvelar as potencialidades do espaço para os agentes educacionais escolares.

Outro pressuposto teórico importante parte do conceito de "distâncias sociais" elaborado pelo antropólogo Edward T. Hall (1914-2009). Hall afirma que são formados limites físicos e de interação em conformidade com as distâncias espaciais entre as pessoas, do mesmo modo que as distâncias estabelecidas nos informam quais serão os modos possíveis de relação a serem desenvolvidas, ainda que isso não esteja explícito. 0 autor delimitou quatro distâncias especificas, do particular ao geral, que sinalizam as possibilidades de interação social $(2010$, p. 142). Para esta pesquisa, são importantes as conceituações do intervalo entre a distância íntima e a pessoal - menor grau de distanciamento e maior riqueza de informações corporais transmitidas; e do intervalo entre a distância social e pública - menor e mais impessoal conjunto de informações corporais transmitidas.

\section{A ABERTURA DO ESPAÇO NAS TIPOLOGIAS ESCOLARES}

O século XX foi um campo amplo de experimentações da abertura espacial na sala de aula, cuja transformação assinala distintas possibilidades e discursos dos espaços educacionais. São significativas as primeiras experiências alemãs das escolas abertas ao ar livre no início do século, em que o pressuposto de uma delimitação física da classe é rompido, ainda que as justificativas tivessem relação direta com a condição de saúde debilitada dos alunos, como ilustra a figura 1. 
Figura 1. Escola Muehlhausen em Munique-Gladbach, Alemanha. Sem data

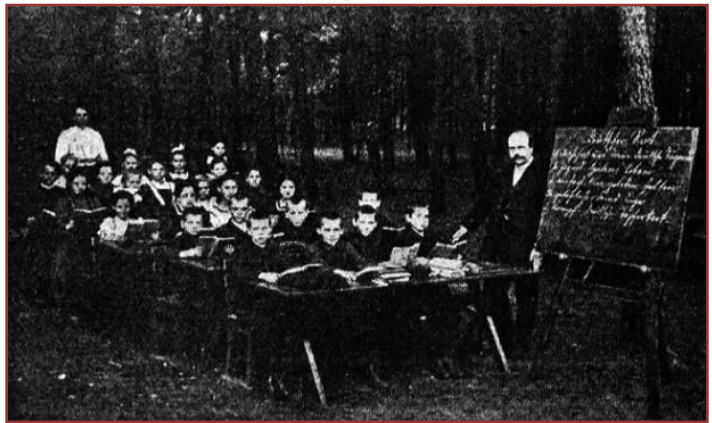

Fonte: KINGSLEY, 2014, p. 127

Um século depois, no projeto piloto de escola na cidade de Barcelona, as salas não se abrem somente ao espaço da escola, mas também ao espaço urbano, estendendo-se à cidade. A cada semana, as crianças experimentam o aprendizado em locais variados, acompanhando o trabalho de profissionais de diversas áreas, explodindo o conceito do espaço escolar único em uma sala, em um conjunto de salas de aula agregadas.

Nesta pesquisa, para aferir os graus de abertura espacial escolar, foram estabelecidas inicialmente quatro tipologias presentes nas escolas públicas brasileiras do ensino Fundamental 1, tendo como objeto principal a sala de aula e suas imediações, considerando que a própria materialidade do perímetro e seu contexto exercem influência no espaço da classe. Nesta primeira classificação das manifestações espaciais de ensino, visualizam-se os graus de abertura oferecidos pelas escolas públicas com a estrutura espacial estabelecida para interação entre seus agentes educacionais, sintetizados no quadro 1.

Quadro 1. Diagrama esquemático em planta das tipologias escolares analisadas

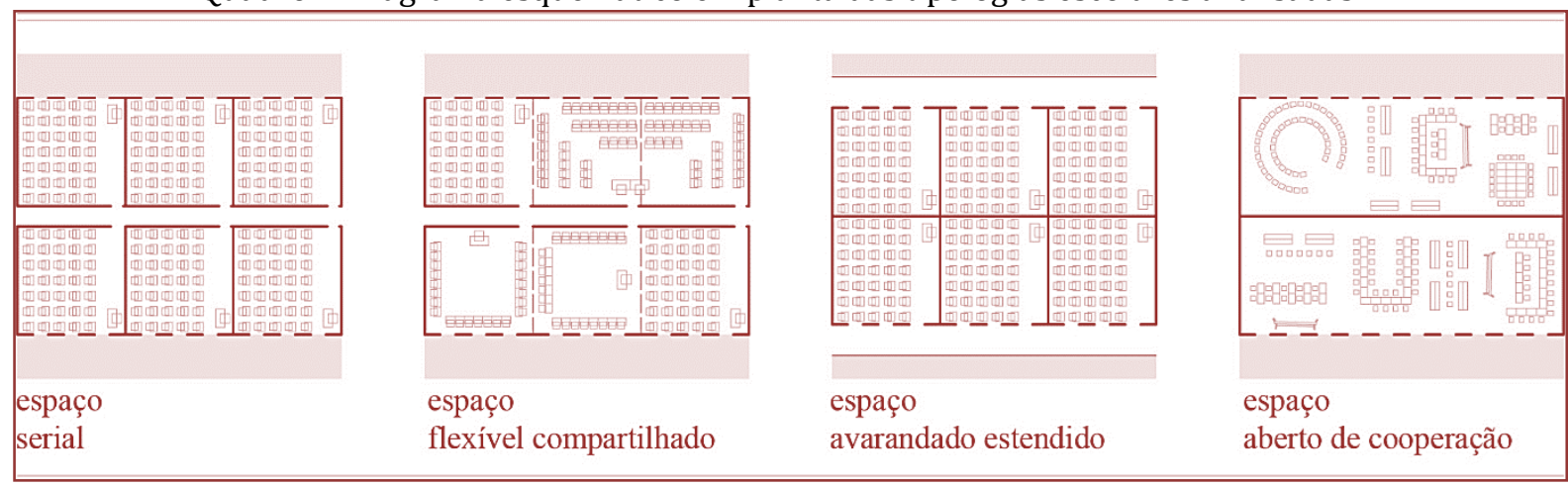

Fonte: autor

\section{ESPAÇO SERIAL}

A primeira tipologia analisada é aquela proposta pela Fundação para o Desenvolvimento da Educação (FDE), exemplificada na escola EE Miguel Pistilli em Taubaté-SP, na qual o ensino é global e homogêneo para todos os alunos, seguindo uma diretriz curricular graduada em séries e, em muitos casos, definida pelos conteúdos mínimos previstos em lei. Traduzem-se espacialmente em inúmeras salas de mesmas dimensões onde os professores e alunos interagem. Os tempos de aprendizado são uniformes, e com um espaço hierárquico claramente definido para os docentes perante os discentes, cuja distribuição espacial na sala de aula é homogênea. Os conteúdos didáticos são apresentados pelo professor de modo expositivo, enfatizando a amplitude do intervalo professor-aluno estabelecida através do modo de distância social e pública, enquanto que os alunos entre si estão dispostos a uma distância íntima e pessoal. A dinâmica espacial interna da sala contribui para o fortalecimento da imagem hierárquica do espaço escolar, já que acentua as diferenças entre os agentes atuando diretamente na produção de conflitos desnecessariamente impostos.

Os acessos às salas de ensino são majoritariamente realizados por um corredor central de pouca iluminação natural e ventilação, e dada as condições de confinamento de espaço associadas à baixa luminosidade, há pouco desdobramento para outras atividades que não seja circular em direção ou com 
origem às salas de aula, em ínfimas possibilidades para um uso aplicado ao ensino - ainda sim, é muitas vezes o palco de permanência e controle dos bedéis. A conformação deste espaço escolar exemplifica a repetição como norma - seja na disposição das salas, das carteiras ou dos corredores, correspondente ao esforço de ensino de massas de propagar e universalizar o seu acesso. Ou, como sugere Focault (1999), a arte de distribuir os espaços de modo repetitivo e equivalente não só em escolas, mas também em fábricas, quartéis, hospitais e prisões evidenciando um protocolo disciplinar para amaciar os corpos e as consciências de quem os frequenta.

Como resultado, em uma escala menor no espaço da sala de aula, a conformação das distâncias sociais acaba por induzir a homogeneização e fragmentação dos agentes de ensino: o docente - suficientemente colocado à distância dos discentes, marginalmente à posição na sala; o discente - uniformemente distribuído no espaço restante, embora a própria localização espacial na sala entre frente, fundo e janela acaba por influenciar a postura do aluno perante o ensino - e por último, a distância e o possível alheamento do material didático exposto pelo professor perante a proximidade da uniformidade do livro didático e do personalismo do caderno pessoal manuseado pelo aluno. Em suma, na sala de aula e no seu acesso imediato, estimula-se a especialização da conformação espacial de cada agente envolvido, onde o contato uns com os outros é tanto menor quanto possível.

\section{ESPAÇO FLEXÍVEL COMPARTILHADO}

A segunda tipologia espacial se remete à experiência das escolas polivalentes, seguindo práticas e influências diretas de um grupo de pedagogos americanos (LIMA, 1989, p. 43). Como referência construída, exemplifica-se aqui a Escola Guiomar de Freitas Costas em Uberlândia, MG. Neste protótipo escolar, algumas salas de aula são divididas por painéis móveis sanfonados, permitindo a integração espacial conforme a necessidade. Por um lado, aqui permanecem muitos elementos anteriormente vistos, tais como: o tempo fracionado das aulas, o ensino global com o mesmo conteúdo para todos os alunos, além do mesmo espaço de circulação confinado da escola. Mas há aqui uma nova espacialidade escolar quando se entrelaça o uso das salas de aulas, antes compartimentadas. Assim, as salas podem ser agrupadas em diferentes anos letivos e idade dos alunos, permitindo que a relação de uma sala por professor alcance um grupo maior de alunos, com três professores, mediante a abertura dos painéis. Como consequência, ao invés da inequívoca especialização dos espaços da escola pontuada anteriormente, a abertura das salas de aula permite, em tese, dinamizar relações possíveis de ensino-aprendizagem no espaço.

Os grupos de alunos poderiam estar em sintonia específica conforme as atividades previstas, onde um dos professores ensinaria a mesma disciplina para os alunos com maior facilidade de aprendizado e os outros dois professores permaneceriam com aqueles com maior dificuldade, assim como seria possível separar as atividades de uma mesma disciplina conforme o professor. Neste caso, cada um dos três professores seria responsável por um dos conteúdos das aulas, e quando um dos três faltasse, seja por questões administrativas ou de saúde, as aulas poderiam ser realizadas em conjunto para todos alunos, sem a necessidade de uma parte permanecer ociosa. Em atividades combinadas para um mesmo grupo, um professor poderia assumir a responsabilidade de apresentar novas habilidades e conceitos e propor tarefas de estudo. Os outros professores poderiam se juntar ao professor especialista como monitores e ajudar durante o tempo de estudo. Algumas experiências poderiam ser compartilhadas, assim como a projeção de filmes e a fala de um palestrante externo.

Em suma, mesmo sem descrever todas as variações de grupo e atividades possibilitadas pelos painéis sanfonas móveis, pode-se depreender que as dinâmicas propostas das salas de aula modificam as relações internas dos agentes: pelas distâncias sociais entre docentes e discentes entre si, pela mistura de idades, classes e quantidade de professores, mesmo que ainda que permaneçam as aulas expositivas e os materiais didáticos anteriormente oferecidos. Entretanto, o que em parte inviabiliza o melhor aproveitamento desta flexibilidade é a necessidade do diálogo entre os docentes, que em muitos casos nem são estabelecidos para evitar intermediações com outros professores de sua própria sala. $O$ inferno são os outros, mas neste caso, mais imaginário do que real, já que muitos dos professores de escolas polivalentes declararam não haver experimentado a integração espacial por conta da exposição a outros colegas, mantendo assim os grupos escolares permanentemente fragmentados (LIMA, 1989, p. 43). 
A terceira tipologia escolar tem por exemplar o CEU dos Meninos na cidade de São Paulo-SP, um dos 21 complexos escolares construídos entre 2003 e 2004(LOPES, 2011, p. 69). Apesar da forma escolar não apresentar diferenças na maioria dos conceitos anteriormente abordados, em dois pontos se alteram as distâncias sociais tanto das crianças quanto dos professores: os corredores agora são externos, compartilhando as janelas das salas, de maior comprimento na secção² e servindo a metade dos alunos, já que estão duplicados nas duas extremidades do edifício. Constituídos como duas grandes varandas, apresentam uma situação intermediária entre espaço interno e externo, desfrutando da iluminação e ventilação natural ao mesmo tempo em que são protegidos da chuva.

Figura 2. Vista do corredor avarandado CEU dos meninos.

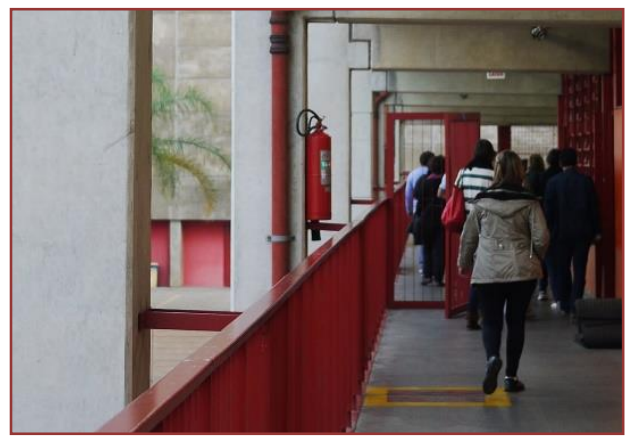

Fonte: autor

Não se trata, contudo, de uma simples adição de área de circulação; os corredores, neste caso assumem o que o sociólogo Richard Sennett (1943) denomina por fronteira (2012, p. 257): um limiar ativo entre dois espaços, neste caso, entre a salas de aula e a circulação vertical de acesso. 0 aumento da secção faz com que a varanda se conforme com espaço de estar, ao invés de se especializar no ir e vir, e com isso tem-se a possibilidade de estender as atividades da sala de aula, como também retomar o sentido original da palavra corre-dor, de estímulos físicos para brincadeiras e outras atividades legítimas e intrínsecas ao desenvolvimento da criança. Neste sentido, o acesso avarandado às salas de aula do CEU tem uma flexibilidade de uso desenvolvida na tipologia anterior, ainda que sua definição das atividades seja mais precisa, e por isso, mais intensivamente utilizada: segundo Lima (1989, p. 72), trata-se de uma visão a ser defendida nos espaços educacionais, para a qual "é preciso, pois, deixar o espaço suficientemente pensado para estimular a curiosidade e a imaginação da criança, mas incompleto o bastante para que ela se aproprie e transforme esse espaço através de sua própria ação".

Outro aspecto distinto no CEU se remete à extensão curricular, que se anteriormente atendia ao mínimo exigido por lei, passa a oferecer outras atividades, em uma estrutura maior e com maior diferenciação dimensional do espaço do que apenas as salas de aula e laboratórios. Nesta nova conformação, a hierarquia e a distância dos alunos com os professores são sublimadas junto às novas atividades de dança e teatro; além disso, e por integrar em uma mesma escola diferentes anos escolares anteriormente não contemplados, há uma convivência pública entre as distintas idades - berçário, ensino infantil e fundamental I - anteriormente fragmentadas.

\section{ESPAÇO ABERTO DE COOPERAÇÃO}

Por último, destaca-se o modelo que altera quase integralmente as concepções de forma escolar determinantes até o momento, em uma graduação maior da abertura do espaço. Entre os exemplos desta proposta, é destacado a EMEF Des. Amorim Lima quanto na EMEF Presidente Campos Salles, ambos em São Paulo-SP

Nesta tipologia espacial, as paredes entre as salas de aula foram abolidas, incorporando os corredores de acesso das salas de aula quando possível, já que as escolas sofreram um processo de adaptação de uma estrutura pré-existente. 0 grupo escolar de aproximadamente 40 alunos foi dissolvido, e o ensino foi individualizado em conformidade com as aptidões ou mesmo dificuldades individuais discentes. Do ensino

2 Os corredores do FDE atendem o mínimo estipulado pela instrução técnica 11/2014, ou seja, chegando a 1,2 m em muitos casos, enquanto no CEU chegam a $2 \mathrm{~m}$. Em termos objetivos, isto significa que a passagem permite 1 adulto e 1 criança no primeiro caso e 3 crianças e 1 adulto no segundo. 
global, passa-se ao grupo de estudos, e os materiais, antes majoritariamente apresentados pelos professores no quadro negro, são em grande medida manuseados pelos alunos individualmente. Da mesma forma como ocorreram com as escolas de paredes móveis, os professores são obrigados a dialogar entre si, de modo que as dinâmicas voltadas aos alunos possam ser planejadas em conjunto.

Nessa nova configuração espacial mais ampla e aberta, observa-se a necessidade de se repensar a acústica escolar adaptada para minimizar as reverberações produzidas pelos alunos e professores, de modo que as atividades dos alunos não prejudiquem umas às outras. Por outro lado, embora nem todos estes recursos sejam aplicados nestas escolas, são descritos abaixo algumas das medidas disponíveis para regular as distâncias sociais, dada a ampliação da escala do espaço voltada às crianças:

Mobiliário móvel e equipamentos podem ser alocados para reduzir a distração visual e regular a movimentação. Estantes de livros, gabinetes, mancebos e lousas portáteis podem servir para definir o espaço. Ou o mérito da definição das áreas é o resultado do próprio projeto espacial. Podem haver diferentes cotas de nível, com acesso a um mezanino onde são alocadas as fontes de material didático. A planta do piso pode oferecer ângulos ocasionais que auxiliam em alcançar algum degrau de isolamento para uma comunidade de aprendizado (FRAZIER, 1972, p. 17)

Desse modo, ao invés de um claro posicionamento espacial dos agentes educacionais ao longo do tempo escolar, no espaço aberto de cooperação se utiliza como recurso os próprios elementos componentes do projeto de arquitetura para mediar distâncias sociais mais pessoais para o ensino. A outra possibilidade, implementada nestas escolas, faz referência à própria definição espacial por meio do deslocamento de mobiliários especiais, sejam estas divisórias improvisadas como estantes ou mesmo móveis volantes, organizados conforme a necessidade.

\section{CONSIDERAÇÕES FINAIS}

A fragmentação das distâncias sociais produzidas pelo espaço serial induz a um contato mínimo entre os docentes e discentes, implicando uma interação tanto menor quanto possível no espaço escolar. As outras tipologias identificadas, por intermédio de uma flexibilização dos limites físicos das salas de aula, evidenciam uma gradual abertura do espaço, cujo resultado imediato é uma possível flexibilização da forma escolar.

As estratégias adotadas modificam a dinâmica do ensino e aprendizagem da sala de aula, seja por intermédio de painéis móveis entre salas, pela reorganização do corredor mais amplo e avarandado ou da eliminação das paredes entre as salas, como exemplo das soluções empregadas nas demais tipologias pesquisadas.

Entretanto, quanto maior for o grau de flexibilidade observado, em particular no espaço compartilhado e no espaço aberto de cooperação, tanto mais será necessária uma integração das práticas dos docentes, impondo a realização do diálogo e do planejamento comum para que o uso do espaço seja efetivo.

\section{REFERÊNCIAS}

[1] Escolano, Augustin. Arquitetura como programa. Espaço-escola e currículo. In:___Frago, Antonio Viñao. Currículo, Espaço e Subjetividade: a arquitetura como programa. Rio de Janeiro: DP\&A, 2001, cap. 1, pg 19-58.

[2] Frazier, A. Open Schools for Children. Washington: ASCD Publications, 1972.

[3] Focault, M. Vigiar e Punir: Nascimento das Prisões. Petrópolis: Vozes, 1999.

[4] Hall, Edward Twitchell. A Dimensão Oculta. São Paulo: Martins Fontes, 2010.

[5] Lahire, Bernard; Thin, Daniel; Vincent, Guy. Sobre a história e a teoria da forma escolar. Educação em Revista, Belo Horizonte, v. 16, n. 33, jun. 2001.

[6] Kingsley, Sherman Colver. Open-Air Schools. Washington: Government Printing Office, 2014.

[7] Lahire, Bernard; THIN, Daniel; Vincent, Guy. Sobre a história e a teoria da forma escolar. Educação em Revista, Belo Horizonte, v. 16, n. 33, jun. 2001.

[8] Lima, Mayumi Souza.. A Cidade e a Criança. São Paulo: Nobel, 1989. 
[9] Lopes, Ana Carolina Louback. Os Meadros da Produção Pública na Construção da Paisagem Periférica Paulistana: O Caso dos Equipamentos Educacionais. 2011.vi, 275 f. Dissertação de Mestrado (Mestrado em Arquitetura e Urbanismo) - Faculdade de Arquitetura e Urbanismo da Universidade de São Paulo, 2011.

[10] Sennett, Richard. O Artífice. São Paulo: Editora Record, 2012. 


\section{Capítulo 7}

\section{Resiliência: Um estudo sobre os fatores de risco e proteção no contexto da escola}

\section{Sandreia Pantoja Lobato \\ Michelle Carneiro Serrão}

Resumo: 0 presente artigo traz uma breve discussão teórica a respeito da Resiliência como fator relevante para o desenvolvimento humano e social de crianças e adolescentes a partir do processo de socialização no espaço escolar. Serão enfatizados nesta pesquisa os fatores de risco e proteção, os quais estão correlacionados, assim como uma discussão teórica em torno do conceito de Resiliência e seus aspectos no que diz respeito ao processo de interação da criança e adolescente na escola. Algumas questões a serem consideradas nesta pesquisa seria enfatizar que a escola não apresenta apenas fatores de proteção, o qual é visto como um fator positivo para a resiliência, mas que os fatores de risco também estão presentes neste espaço, os quais facilitam e impulsionam o desenvolvimento da resiliência, já que os mesmos estão interligados. Serão mencionados estudos realizados sobre a escola acerca dos fatores de proteção relacionando-os a teoria Bioecológica de Urie Bronfenbrenner, que destaca a escola como um microssistema, analisando uma nova dimensão do espaço escolar, não apenas limitando-a as influências comportamentais, mas no que diz respeito ao todo, valorizando a dinâmica das relações. Nesta perspectiva os fatores de proteção contribuem para o desenvolvimento da resiliência e os fatores de risco ajudam a desencadear outros fatores que auxiliarão na superação de traumas vivenciados no ambiente escolar, como uma forma de instigar as crianças e adolescentes a compreender o papel das adversidades em seu cotidiano, portanto a escola colabora de maneira significativa para o processo de adaptação e ajustamento das crianças e adolescentes quanto às suas experiências negativas vividas na escola.

Palavras-Chave: Resiliência. Escola. Fatores de Risco. Proteção. 


\section{INTRODUÇÃO}

Esta pesquisa aborda o tema da resiliência e traz uma discussão em torno dos fatores de risco e proteção no que diz respeito ao desenvolvimento humano, relacionando-o à promoção de resiliência. Inicialmente serão definidos os conceitos de resiliência e os fatores de proteção para então conhecermos de maneira abrangente este tema instigante.

Para uma melhor compreensão desta pesquisa o foco será direcionado para um dos ambientes importantes para o desenvolvimento humano - a Escola. Portanto serão apresentados estudos colhidos na literatura que dão enfoque aos fatores de proteção utilizados constantemente por crianças e adolescentes inseridos em espaços escolares que apresentavam índices de exclusão e vulnerabilidade social, conforme os estudos apresentados.

Será também apresentado o modelo Bioecológico (modificado recentemente) proposto por Urie Bronfenbrenner ${ }^{3}$, pois esta teoria contempla o desenvolvimento de maneira ampla, integrando a compreensão dos aspectos da vida da pessoa, seja o tempo em que vive, os ambientes dos quais participa e as relações que estabelece e é focalizada nas interações das pessoas com seus diferentes contextos (DESSEN, COSTA JR, 2005). Ela foi utilizada como base teórico-metodológica para analisar o ambiente escolar e a relação com os fatores de risco e/ou proteção.

Pretende-se relacionar o modelo Bioecológico com a percepção das crianças e adolescentes a partir da vivência nas escolas que estão envolvidas nas pesquisas a que se teve acesso e que apresentam situação de risco psicossocial e econômico. Por essas e outras questões é importante questionar se a resiliência se desenvolve também a partir das relações que as crianças e adolescentes estabelecem com o meio em que vivem, neste caso específico, a Escola.

\section{REVISITANDO OS CONCEITOS DE RESILIÊNCIA - ÊNFASE NA PROTEÇÃO.}

Resiliência é um conceito originário da física, ciência na qual este constructo é definido como a capacidade de um material absorver energia sem sofrer deformação plástica. Em psicologia este conceito está superado, pois uma pessoa não pode absorver um evento estressor e voltar à forma anterior. Ela aprende, cresce, desenvolve e amadurece.

Este conceito nos traz uma compreensão de que o ser humano passa por um processo de transformação de um dano ou trauma sofrido em uma situação positiva, como se o corpo e a mente tivessem a capacidade de reverter o ocorrido, o que traz muitos questionamentos sobre o entendimento que vamos construindo sobre o tema.

Pesquisas sobre esse tema ainda são escassos na educação, no que diz respeito ao processo ensino e aprendizagem e na relação interpessoal que se estabelece entre os sujeitos envolvidos na dinâmica escolar, das quais surgem situações de traumas, danos, dificuldades emocionais que se bem trabalhadas e conduzidas auxiliam no processo de resiliência dos alunos.

Por esta razão, pode-se destacar que o resiliente é aquela pessoa, ou no caso específico crianças e adolescentes que enfrentam as adversidades e conseguem superá-las a partir da maneira como veem tal situação. Porém hoje existe um número expressivo de conceitos referentes à resiliência, e estes vêm sendo aprofundados ao longo dos anos, principalmente no que diz respeito à resiliência psicológica.

Assis, Pesce e Avanci (2006) enfatizam que o termo já foi entendido como sinônimo de invulnerabilidade, porém hoje há questionamentos, apresentando como um uso equivocado. No entanto, resiliência não denota resistência absoluta a qualquer adversidade, pelo contrário, pode implicar em enfrentamento.

Essas concepções trazem ideias diferentes sobre o desenvolvimento da resiliência. Enquanto uma exprime a soma de poderes que o indivíduo foi constituindo no decorrer da vida, a outra traz uma forma diferente de lidar com as adversidades, considerando como o indivíduo se vê na situação e a enfrenta. A invulnerabilidade dá a impressão de que o indivíduo não sofre, não se envolve com o problema, não tem sentimentos, enfim, é visto como uma fortaleza.

\footnotetext{
3 Teórico russo que traz o embasamento teórico sobre o Modelo Bioecológico para o estudo do desenvolvimento Humano. Graduou-se em Música e em Psicologia pela Universidade de Cornell, mestrado em Harvard e Doutorado na Universidade de Michigan em 1942. Sua biografia completa encontra-se disponível em http://www.people.cornell.edu/pages/ub11.
} 
Partindo para outra concepção, destaca-se o que Assis, Pesce e Avanci (2006) discutem sobre a resiliência. Ela é vista como uma capacidade individual de adaptação bem- sucedida em ambiente "adverso" e como qualidades elásticas e flexíveis do ser humano, qualidades estas que vão se desenvolvendo devido as adversidades que este vai passando e enfrentando.

Percebe-se, a partir das concepções apresentadas, que nos últimos anos a noção de resiliência vem se tornando complexa, por ser abordada como processo dinâmico que envolve a interação entre processos sociais e intrapsíquicos de risco e de proteção e no espaço escolar as crianças e adolescentes vão se desenvolvendo a partir das relações interpessoais que estabelecem com o meio, com as pessoas com as quais interagem, em um processo de socialização.

A resiliência está ancorada em dois grandes pólos: o da adversidade - representado pelos eventos desfavoráveis, e o da proteção - voltado para a compreensão de fatores internos e externos ao indivíduo, mas que o levam a uma reconstrução singular diante do sofrimento causado por uma adversidade. (ASSIS; PESCE e AVANCI, 2006)

Por meio do processo educativo, as crianças e adolescentes passam por situações de aprendizagem ou interação social desfavoráveis ou desconfortáveis, tirando-os de sua zona de conforto e colocando-os naturalmente em situações de embate, divergências, diferentes das quais estão habituados até então, o que os conduz ao processo de desenvolvimento da resiliência dentro do espaço escolar, preservando suas estruturas psicológicas, o que refletirá ao longo de suas vidas.

É importante mencionar que há divergências na literatura sobre a capacidade desses fatores predizerem efetivamente a resiliência, pois para Trombeta e Guzzo (2002) apenas os fatores de proteção são preditivos a resiliência, enquanto os fatores de risco não possuem tal capacidade.

De fato, quando aspectos individuais e sociais agem proativamente, funcionam como mecanismos de proteção. Por isso Brooks, 1994; Emery e Forehand, 1996; Garmezy, 1985 apud Assis, Pesce e Avanci (2006) destacam que os mecanismos de proteção de que um indivíduo dispõe internamente ou que capta do meio em que vive são elementos cruciais para estimular o potencial de resiliência ao longo da vida. Ou seja, estes mecanismos são de suma importância para desenvolver a capacidade de um indivíduo resiliente.

Para Assis, Pesce e Avanci (2006) os fatores de proteção devem ser abordados como processos, através dos quais diferentes fatores interagem entre si e alteram a trajetória da pessoa, produzindo uma experiência de cuidado, fortalecimento ou anteparo ao risco.

Por isso, definir efetivamente o que é ou não risco ou proteção parece complicado, pois as interações e combinações de seus efeitos necessitam de uma cuidadosa análise.

Segundo Assis, Pesce e Avanci (2006), uma criança e/ou adolescente tende a ser mais vulnerável quanto menos fatores de proteção perceber em seu meio para ajudá-la a enfrentar as dificuldades existentes; de maneira oposta, as crianças e adolescentes tendem a ser mais resilientes quanto mais fatores de proteção captarem do meio em que vivem ou do espaço em que se encontram, no caso, a escola.

A partir desta afirmação é importante ressaltar que os fatores de proteção ajudam as crianças e adolescentes a desenvolverem suas forças internas, construindo uma espécie de fortaleza.

A partir de vários estudos de Garmezi e Masten (1985) apud Libório (s/d), pode-se observar que alguns fatores de proteção são fundamentais ao desenvolvimento, quais sejam: 1- Atributos disposicionais das pessoas, tais como autonomia, auto-estima, bem-estar subjetivo e orientação social positiva, além de competência emocional, representação mental de afeto positivo e inteligência, o que caracteriza um desenvolvimento psicológico saudável e ajuda na construção das potencialidades de um indivíduo resiliente. Outro fator de proteção é a rede de apoio social, com recursos individuais e institucionais, que encoraje e reforce as crianças e adolescentes a lidarem com as circunstâncias da vida.

Existe ainda a coesão familiar, ausência de negligência e possibilidade de administrar conflitos, com a presença de pelo menos um adulto com grande interesse pelas crianças e adolescentes, e presença de laços afetivos no sistema familiar e/ou em outros contextos que ofereçam suporte emocional em momentos de estresse. A presença dos pais ou de um adulto na vida escolar das crianças e adolescentes e seu efetivo acompanhamento, pode servir como mecanismo de proteção, dando suporte para o enfrentamento de situações novas e desafiadoras que as levem ao desenvolvimento da resiliência.

Estes fatores ajudam a reduzir o impacto dos riscos, reduzir as reações negativas em cadeia, estabelecer e manter a autoestima e autoeficácia, por meio do estabelecimento de relações de apego seguras e o 
cumprimento de tarefas com sucesso e criar oportunidade para reverter os efeitos de um possível estresse.

Segundo Libório (s/d) os processos de resiliência são construídos mediante a exposição dos indivíduos às situações de risco ao seu desenvolvimento, portanto não podemos falar do fenômeno de resiliência sem a presença de riscos significativos para certa cultura e contexto, que determinam se uma situação específica é ou não prejudicial para as adolescentes de seu grupo social.

\section{DISCUSSÃO A PARTIR DO MODELO BIOECOLÓGICO DE DESENVOLVIMENTO HUMANO DE URIE BRONFENBRENNER.}

A noção de desenvolvimento proposta por Bronfenbrenner está intrinsecamente associada às estabilidades e mudanças que ocorrem nas características biopsicológicas da pessoa durante o seu curso de vida e ao longo de gerações.

[...] O desenvolvimento [...] é conceituado e investigado como um produto e também como um processo, vistos em uma íntima conexão um com o outro. Tanto os efeitos do desenvolvimento são evidenciados quanto as suas propriedades - isto é, os processos que operam na pessoa e no ambiente - de forma a provocar mudanças significativas em ambos [...]. (BRONFENBRENNER apud DESSEN et. al., 2005, p. 74)

Na concepção de Bronfenbrenner (1999) apud Dessen e Costa Junior (2005) o desenvolvimento representa uma transformação que atinge a pessoa, que não é de caráter passageiro ou pertinente apenas a situação ou a um dado contexto. Trata-se de uma reorganização que procede de maneira continuada dentro da unidade tempo-espaço. Esta modificação se realiza em diferentes níveis: das ações, das percepções da pessoa, das atividades e das interações com o seu mundo.

Neste modelo também é proposto que o desenvolvimento humano seja estudado por meio da interação deste núcleo com outros três, de forma interrelacionada: o processo, a pessoa e o tempo, ampliando o foco do modelo.

É salientado que "[...] os aspectos do meio ambiente no curso do crescimento psicológico são, de forma esmagadora, aqueles que têm significado para a pessoa numa dada situação" (DESSEN; COSTA JUNIOR, 2005), portanto, diferentes contextos como família, instituição e escola podem ter influências diversas no desenvolvimento.

A escola é um ambiente que regulamenta o desenvolvimento do indivíduo e que possui papel fundamental na socialização, pois é nela que as crianças e adolescentes passam maior parte do seu tempo.

Nesse contexto, as crianças e adolescentes experienciam inúmeras situações: relações entre pares, grupos, amizade, competição, aprendizagem e descoberta do novo, entre outros. Partindo deste olhar, percebe-se o que Lisboa (2005) apud Poletto e Koller (2008), trata sobre o espaço da escola, que esta pode promover a auto-estima e auto-eficácia das crianças e adolescentes, capacitando-os em habilidades sociais, além de influenciar o relacionamento entre o grupo de iguais por meio de normas, regras e da cultura da Instituição.

Um estudo realizado por Rutter apud Libório (s/d) na década de setenta se propôs a investigar a influência do ambiente escolar, de suas características de organização e funcionamento no desenvolvimento das crianças e adolescentes.

A pesquisa constatou que as condições físicas, estruturais, número e quantidade de recursos das escolas são menos relevantes para o sucesso das crianças e adolescentes do que as relações interpessoais que são estabelecidas na escola. Segundo Camargo (2009) apud Libório (s/d) as atitudes dos professores no que diz respeito ao incentivo a aprendizagem, suas concepções e práticas pedagógicas interferem significativamente no processo ensino e aprendizagem da maioria das crianças e adolescentes.

E este é outro pressuposto central do modelo de Bronfenbrenner, o aspecto da bidirecionalidade, que assegura a interdependência e a influência mútua entre o indivíduo e seu ambiente, de maneira a permitir a compreensão dos efeitos e dos mecanismos que atuam de maneira sistêmica sobre os processos evolutivos (DESSEN e COSTA JUNIOR et al, 2005). Esta influência mútua entre o indivíduo e seu ambiente ocorre por meio das relações interpessoais e do intercâmbio permanente entre os contextos de desenvolvimento. 
Bronfenbrenner (1977, 1979/1996) apud Dessen e Costa Junior (2005) resgata o papel ativo, interativo e protagonista do indivíduo como agente de mudança, rompendo com algumas premissas em que o indivíduo apenas recebe as influências do ambiente. Nesta perspectiva, dar-se-á ênfase apenas ao conceito de validade ecológica.

A validade ecológica refere-se à extensão pela qual as crianças e adolescentes em desenvolvimento experimentam o seu ambiente, considerando as propriedades ou condições específicas resultantes do que será pesquisado. Sustenta preceitos em relação à pesquisa, à medida que leva em conta como as crianças e adolescentes em desenvolvimento percebem a si própria na situação, interagindo no ambiente escolar.

Neste caso, ao se considerar a relação das crianças e adolescentes com e no ambiente escolar, é de suma importância, a compreensão que elas têm deste espaço e a percepção que elas foram construindo no decorrer do tempo, considerando suas relações sociais, interpessoais e o processo de aprendizagem o que pode ajudar a melhorar as relações existentes na escola, no que diz respeito a relação aluno-professor e aluno-aluno.

\section{A ESCOLA ENQUANTO ESPAÇO DE MEDIAÇÃO: O USO DE FATORES DE PROTEÇÃO ENVOLVENDO CRIANÇAS E ADOLESCENTES EM SITUAÇÃO DE VULNERABILIDADE.}

A família que ainda aparece como um fator de proteção, ao mesmo tempo também pode ser considerada um fator de risco, a qual é vista como o grupo social básico das crianças e adolescentes, desde o vínculo positivo entre estes e seus pais (ou cuidadores). Então a família protetiva proporciona o alicerce necessário para a socialização (Hawley e Dehann (1996) apud Poletto e Koller (2008). Porém, neste estudo a ênfase será dada ao papel da escola como ambiente que pode propiciar fatores de proteção as crianças e adolescentes que vivenciam ambiente "adverso".

De acordo com Camargo (2009) e Henderson e Milstein (2003) apud Libório (s/d) quando nos remetemos aos fatores de proteção, um aspecto central refere-se à dimensão relacional, ou seja, as relações significativas de afeto e confiança com indivíduos que representem o "outro significativo", agindo como mobilizador de processos de resiliência.

Pesquisas realizadas no Brasil enfatizam os fatores de proteção advindos também do ambiente escolar. Por isso, discutimos seus resultados e possíveis reflexões para intervenções necessárias.

Uma pesquisa realizada com 109 adolescentes em situação de risco psicossocial de duas escolas públicas no Distrito Federal analisou os fatores de proteção utilizados pelos mesmos, os quais consideraram a percepção da qualidade de vida e da própria saúde, vida sexual e redes sociais de apoio. As pesquisadoras concluíram que em relação aos fatores de proteção identificados apresentou-se bons resultados, tanto no nível individual, como nos familiares e do meio ambiente.

Consideraram o ambiente escolar com qualidade boa ou muito boa (apesar da precariedade do local). Foram consideradas expectativas expressivas sobre o futuro, e a grande importância da escola na atualidade para a maioria deles (GALVÃO; KOLLER, et al s/d).

Outra pesquisa analisada foi realizada com 852 adolescentes e jovens (complementar a primeira pesquisa) na faixa etária de 13 a 27 anos, cursando o ensino médio em escolas públicas das regiões administrativas de Planaltina, Brazlândia, Paranoá e Samambaia do Distrito Federal. Tal pesquisa faz parte de um estudo mais amplo, a nível nacional, em alguns estados do Sul, Sudeste, Centro-Oeste e Nordeste do Brasil com o objetivo de traçar o perfil mais amplo dos adolescentes e jovens em situação de risco psicossocial nestas regiões. 0 método utilizado foi um questionário com 109 questões de múltipla escolha que buscava investigar aspectos sobre redes de apoio social (família, amigos e escola) e fatores de proteção social (religiosidade-espiritualidade e auto-estima) definidos como indicadores potenciais de processos resilientes (AMPARO; GALVÃO; ALVES, BRASIL, KOLLER, 2008).

Os resultados sobre as redes de apoio social mostram o envolvimento positivo da família em relação a três questões: aos estudos, a segurança percebida pelos adolescentes e jovens e um ambiente sem conflitos. Outro grupo importante para ser mencionado é a rede de amigos, que na pesquisa foi identificado como muito importante para um desenvolvimento saudável.

Outro fator de proteção e promotor de resiliência mencionado na pesquisa acima refere-se ao tipo de envolvimento que eles têm com a escola. As percepções sobre o papel da escola e dos estudos na vida dos adolescentes e jovens que participaram da pesquisa foram positivas, mencionaram a importância dos estudos naquele momento e para o futuro, enfatizando o desejo de fazer uma faculdade e o 
reconhecimento de que é necessário esforço pessoal para alcançar seus objetivos. (AMPARO, GALVÃO, ALVES, BRASIL e KOLLER, 2008).

Este resultado apenas confirma a importância do papel da escola para o desenvolvimento das percepções positivas dos alunos em relação ao seu futuro, destacando sua influência.

Segundo Amparo, et al (2008) destacou-se o ambiente escolar na pesquisa como um espaço de qualidade boa ou muito boa, considerando-se a valorização do estudo (confiança no seu desempenho acadêmico) e os relacionamentos dentro e fora do ambiente escolar contribuírem para a capacidade de resiliência desses adolescentes e jovens, além do fato deles cursarem o ensino médio poder contribuir para a permanência deles na escola, fato observado pelas pesquisadoras como uma característica protetiva, o que pode reduzir a exposição ao risco psicossocial.

Crianças, adolescentes ou jovens oriundos de famílias de nível socioeconômico muito baixo, de acordo com Rutter (1993) apud Libório (s/d), conseguem desenvolver projetos futuros de uma forma melhor quando vivenciam experiências positivas na escola.

Numa outra pesquisa sobre resiliência foram entrevistados 997 alunos com idades entre 12 e 19 anos em 17 escolas públicas no município de São Gonçalo (RJ), pois os pesquisadores acreditavam que as variáveis risco/proteção são peças fundamentais que se combinam no cenário complexo desse construto. (PESCE, ASSIS, et al, 2004). A pesquisa é um ensaio exploratório sobre associação da resiliência com eventos de vida adversos e com fatores de proteção.

Os resultados apresentados na pesquisa mostraram que os eventos traumáticos de vida não estão relacionados com as características de um indivíduo resiliente (PESCE, ASSIS, et al, 2004), visto que não se pode afirmar que vivenciar um evento ou experiências negativas contribui para desenvolver capacidades de lidar com a adversidade, mas há que se considerar o processamento da experiência negativa como fator importante para a resiliência. Portanto eles afirmaram que quando o jovem sucumbe ao risco, ele está propenso a ter mais dificuldade em sair-se bem frente aos desafios da vida.

Já os fatores de proteção evidenciados na pesquisa (auto-estima, apoio social, gênero e relacionamento com outras pessoas), segundo Pesce, Assis, et al (2004) tiveram associação com a resiliência, confirmando a hipótese teórica que molda este construto, e atuam como facilitadores no processo individual de perceber e enfrentar o risco.

Para definir um fator que protege uma criança, como um fator de risco, e de um resultado pouco resiliente, é preciso definir o significado de risco em algum lugar entre os dois pólos: a situação ou circunstância que oferece o risco e o resultado mais ou menos resiliente, pois neste intervalo podem estar os fatores que oferecem proteção e que podem ajudar o indivíduo a dimensionar o risco.

Porém a escola também apresenta fatores de risco que podem prejudicar o desenvolvimento da criança ou adolescente. Podemos verificar que a partir de um estudo realizado por Lisboa et al (2002) apud Poletto e Koller (2008) com crianças, as agressões verbais dos professores foram observadas por elas como um dos problemas mais frequentes. Segundo o autor, esses professores não representavam fatores de proteção. Apesar de que é possível constatar que crianças e adolescentes possam ver a escola como um espaço para a promoção de processos de resiliência, por meio de projetos e atividades que estimulem as potencialidades individuais e a cooperação (POLETTO e KOLLER, 2008).

Segundo Sudbrack e Dalbosco (2005) apud Libório (s/d) são destacados vários fatores de risco presentes na escola, tais como: falta de negociação de normas e regras, relações interpessoais desrespeitosas entre alunos e profissionais, relação família-escola ausente, expectativas negativas com relação ao desempenho dos alunos, atividades acadêmicas pouco criativas, presença de estigma (rótulo) em relação a certos alunos, relação professor - aluno carente de afetividade, baixo nível de confiança no ambiente escolar e pouco incentivo ao altruísmo, cooperação e solidariedade.

Portanto, é necessário observarmos que a escola é um ambiente que pode ser utilizado de maneira bastante produtiva e estes pontos negativos podem ser trabalhados de maneira concreta pelos próprios profissionais, e ela se tornar promotora e/ou mediadora de ações que favoreçam a proteção de crianças e adolescentes em situação de risco psicossocial.

A novidade que estes estudos mais recentes trazem sobre resiliência, é a ênfase na promoção de processos educativos e de convivência que facilitem ou tornem as pessoas mais resistentes e maduras para enfrentar as dificuldades que ocorrem na vida de qualquer ser humano (ASSIS, PESCE e AVANCI, 2006). 
A escola tem a vantagem de acompanhar o crescimento e o desenvolvimento dos jovens e de ter acesso aos pais e responsáveis. Seu papel no desenvolvimento da resiliência pode ser exercido nas mais diferentes atividades, como: trabalhar atividades específicas e apropriadas para cada faixa etária; ensinar a coordenar e integrar a área cognitiva, afetiva e comportamental; articular área acadêmica com a educação para a saúde e para a vida familiar; criar materiais claros, modernos e didáticos; capacitar professores e pessoas especializadas que tem papel fundamental na vida dos alunos. (ASSIS, PESCE e AVANCI, 2006).

\section{CONSIDERAÇÕES FINAIS}

A escola pode representar, assim como a família em alguns casos, fator de risco para o desenvolvimento saudável, sendo bastante comum a vitimização ou bullying. Muitas vezes o discurso da escola não parece ter relação com a realidade do cotidiano de algumas crianças e adolescentes, no caso das propostas metodológicas e educacionais e exigências discrepantes em relação às condições estruturais e culturais vividas por essas crianças e adolescentes em outros contextos.

Alguns estudos sobre resiliência indicam (talvez não intencionalmente) que aqueles indivíduos que não se enquadram no que a cultura determina, o que é esperado como sendo dentro de um "desenvolvimento normal" acabam sendo responsabilizados pela ausência de resultados "positivos".

Por esta razão, é necessário repensar sobre as variáveis que podem estar influenciando o seu comportamento, e não direcionar apenas para resultados "positivos" que avaliam a competência individual, mas considerar o caráter relacional, articulando o individual com o contextual, e a dinâmica do ambiente devido às transformações que ocorrem no espaço, tempo e pessoa, que são constantes.

0 modelo bioecológico do desenvolvimento humano de Bronfenbrenner exportou para os estudos sobre desenvolvimento infanto-juvenil a noção de que o ambiente precisa ser valorizado conforme ele é percebido pelo indivíduo, e não conforme ele exista na realidade objetiva.

Portanto é importante questionar qual a percepção que as crianças e adolescentes têm sobre o ambiente escolar, valorizando suas necessidades e direcionando para a busca de um desenvolvimento saudável e mediador das relações sociais, o que pode garantir sua formação social. Por isso, é oportuno utilizar o ambiente escolar para estimular o desenvolvimento da resiliência, bem como para promover a saúde psicológica em crianças e adolescentes.

A Organização Pan-Americana de Saúde (OPAS) tem investido para a promoção da resiliência, e as propostas são para agente de saúde e educadores tentarem mediar ações que incorporem as famílias nas ações protetivas, e direcionar também para o âmbito individual e de programas, respeitando a identidade coletiva, conforme pontuam Assis, Pesce e Avanci (2006).

Portanto destacar a resiliência na atualidade, principalmente com enfoque no espaço da escola, é bastante coerente, já que apresenta pontos que favorecem o seu desenvolvimento, e pelo fato da mesma apresentar fatores de proteção e de risco no seu espaço de mediação, colaborando assim de maneira eficaz para o processo de adaptação no que diz respeito às experiências negativas vividas na escola desde a infância.

\section{REFERÊNCIAS}

[1] Amparo, D., Galvão, A., Alves, P., Brasil, K., Koller, S. Adolescentes e jovens em situação de risco psicossocial: redes de apoio social e fatores pessoais de proteção. Estudos de Psicologia, Natal, 2008.

[2] Assis, S., Pesce, R., Avanci, J. Resiliência: enfatizando a proteção dos adolescentes. Porto Alegre: Artmed, 2006.

[3] Dessen, M. A.; Costa Júnior, A. L. (Org.). A ciência do desenvolvimento Humano: Tendências atuais e perspectivas futuras. Porto Alegre: Artmed, 2005.

[4] Galvão, D., Koller, S., et al. II Congresso Ibero-Americano Sobre Violências Nas Escolas. In:___ Fatores de Proteção dos Jovens em Situação de Risco. Observatório de violências nas escolas, núcleo Pará. Universidade da Amazônia - Unama.

[5] Libório, R. M. C. Escola: Risco, Proteção e Processos de Resiliência durante a adolescência. FAPESP, s/d.

[6] Pesce, R., Assis, S., Santos, N. et al. Risco e proteção: em busca de um equilíbrio promotor de resiliência. Psicologia: Teoria e Pesquisa. Brasília, 2004.

[7] Poletto, M.; Koller, S. Contextos ecológicos: promotores de resiliência, fatores de risco e de proteção. Estudos de Psicologia. Campinas, 2008, p.405-416. 
[8] Trombeta, L. H. ; Guzzo, R. S. L. Enfrentando o cotidiano adverso: estudo sobre resiliência em adolescentes. Campinas: Alínea, 2002. 


\section{Capítulo 8}

Possibilidades de melhoria do clima e cultura organizacional através de práticas de planejamento participativo na educação

\section{Edna Maria Mendes Pinheiro Costa \\ Mailson Martinho \\ Maria de Lourdes Silva Lima \\ Vera Rejane Gomes \\ Osiel César da Trindade Júnior}

Resumo: 0 presente artigo parte de uma reflexão sobre a importância da organização do ambiente escolar e do trabalho coletivo dos sujeitos envolvidos ao se identificarem como agentes transformadores de realidades diversas no processo educacional. 0 texto ressalta o Planejamento Participativo como elemento agregador das ações a se realizarem na escola assim como a formação continuada para o pessoal docente e administrativo, objetivando a prestação de um serviço de qualidade à sociedade e ao mesmo tempo elevar o nível de satisfação profissional.

Palavras-chave: Ambiente escolar, planejamento educacional, formação continuada. 


\section{INTRODUÇÃO}

A escola é caracterizada pelo seu poder de atuação e transformação da realidade dos seus sujeitos. Buscase, então, proporcionar, a partir deste trabalho, uma reflexão acerca da importância do planejamento participativo para o alcance da melhoria do clima e cultura organizacional das instituições escolares. Alguns fatores são apontados como essenciais no processo de construção de uma escola de qualidade, tais como a formação continuada de professores, potencialização de suas qualidades através da valorização do trabalho e conhecimento da realidade vivenciada no contexto escolar.

É necessário que os componentes do corpo escolar sintam-se satisfeitos no ambiente em que atuam. Por ser uma instituição corresponsável pela formação de cidadãos, a escola deve garantir a participação de todos os atores envolvidos em seu planejamento, uma vez que é preciso considerar qual a real necessidade dos alunos para definir as metodologias adequadas para cada situação.

A gestão escolar deve, então, atentar-se para a melhoria do clima e cultura organizacional da escola, favorecendo o crescimento profissional de seus funcionários e fortalecendo as potencialidades dos alunos, de modo que os atores envolvidos sintam-se protagonistas do processo de ensino- aprendizagem.

Neste sentido, o objetivo principal da pesquisa consiste em discutir a relevância e as possibilidades de uma gestão democrática no contexto educacional através da organização do ambiente escolar.

\section{METODOLOGIA DA PESQUISA}

A construção do presente artigo foi realizada através da pesquisa bibliográfica que tem como fundamentação um estudo sistematizado de publicações científicas que abordam o tema em discussão e constitui acesso público em geral. Dessa forma, foram utilizadas as referências bibliográficas de alguns autores, tais como, Libâneo, Lück, Murici, Paro e outros, que enfatizaram a questão do referido tema e a sua importância para uma gestão voltada ao cotidiano do trabalho na escola e a sua contribuição no ensino-aprendizagem de boa qualidade.

Por se tratar de uma pesquisa bibliográfica explicativa, segundo a taxionomia de Vergara (2014, p. 62-63) pode-se constatar que todo o texto aponta para um entendimento sobre as questões que permeiam os fatores relevantes na organização do ambiente escolar e a sua influência no processo educacional.

\section{CLIMA E CULTURA ORGANIZACIONAL DA ESCOLA}

A escola é um espaço de formação sistematizada para as pessoas que nela buscam o conhecimento e de onde a sociedade espera a transformação do indivíduo em cidadão que precisa exercer de fato e de direito a sua cidadania. Para isso, a escola precisa estar apta para tal missão. Os sujeitos nela envolvidos precisam se sentir parte do processo, do contrário, a escola continuará a ser simplesmente um lugar onde o seu corpo escolar não se sente motivado a transformar a sua realidade.

Segundo Libâneo (2015), os objetivos propostos para que a escola seja concebida como espaço de síntese, no exercício de seu papel na construção da democracia social e política, estão pautados na promoção do desenvolvimento de capacidades cognitivas, operativas e sociais dos alunos; no favorecimento das condições para o fortalecimento da subjetividade e da identidade cultural dos alunos; na preparação para o trabalho e para a sociedade tecnológica e comunicacional; na formação para a cidadania crítica e no desenvolvimento da formação para os valores éticos.

Nessa perspectiva, é importante que a escola esteja atenta à construção de agentes transformadores, que estejam abertos para as inovações, sem desprezar as experiências exitosas, às particularidades das partes envolvidas na comunidade acadêmica, aos avanços tecnológicos para uma comunicação mais abrangente que prepare realmente trabalhadores-cidadãos para o mundo do trabalho, de forma competente, crítica, ética e humanizada.

As escolas são, pois, organizações, e nelas sobressai a interação entre as pessoas, para a promoção da formação humana. "A instituição escolar caracteriza-se por ser um sistema de relações humanas e sociais com fortes características interativas, que a diferenciam das empresas convencionais" (LIBÂNEO; OLIVEIRA; TOSCHI, 2003, p.316).

Vale ressaltar que a escola por excelência é uma organização de fundamental importância para a sociedade, pois nela se constrói saberes, afetividade, respeito, disciplina, além de outros valores que contribuirão de forma significativa para o desenvolvimento das potencialidades de seus alunos. 
Segundo Murici e Neuza (2013), uma das dimensões de resultados da escola é o nível de satisfação das necessidades dos envolvidos (moral). As pessoas que fazem parte do contexto escolar quando satisfeitas no ambiente de trabalho produzem e mantêm melhores resultados. Para isso, os fatores motivacionais devem ser medidos e gerenciados sistematicamente e adota como referência o grupamento de necessidades humanas definidas por Abraham Maslow: fisiológicas, segurança, sociais (pertencimento), estima (reconhecimento) e auto realização (gostar do que faz).

A Gestão do clima da escola poderá contribuir para:

- Maior envolvimento dos professores, dos funcionários e dos alunos em relação ao ambiente escolar, gerando mais satisfação e menos absenteísmo (faltas);

- Melhoria no desempenho dos alunos e dos funcionários;

- Melhoria da comunicação na escola e com a comunidade;

- Proatividade da direção/coordenação, antecipando ou solucionando problemas relativos ao ambiente de trabalho;

- Integração e cooperação entre os diversos segmentos da escola.

Sobre esses fatores motivacionais elencadas acima, é importante mencionar que eles não acontecem em "passe de mágica", é preciso que haja interesse, colaboração, trabalho coletivo.

Griffith (1999, apud PEREIRA; OLIVEIRA; TEIXEIRA, 2013, p. 5), elucida bem o pensamento acima quando afirma que:

O clima da escola facilita as interações sociais e individuais, satisfazendo a identidade dos membros do grupo e necessidades interpessoais, chamada expressiva ou emocional ela está dividida em duas formas: Ordem social que refere-se a estrutura social nas escolas, como objetivos da escola, normas e valores, papéis definidos de funcionários e alunos, clima social e a Ação Social relacionada às interações do dia-a-dia entre os alunos, funcionários da escola e os pais.

Dessa forma, a escola deve ser um ambiente capaz de proporcionar uma interação social, a qual possibilita o desenvolvimento do indivíduo enquanto cidadão.

\section{A IMPORTÂNCIA DO PLANEJAMENTO PARTICIPATIVO NA EDUCAÇÃo}

Diante do desafio de construir essa nova escola, há uma necessidade de um trabalho coletivo, organizado por pessoas que se sentem parte dessa escola, que criam dia após dia a sua identidade pautada na sua cultura, que atuam como canal de transformação da sociedade. Para que isso aconteça, é imprescindível que haja um planejamento que não é construído de forma estanque, mas sim processual, respeitando cada etapa que direciona aos resultados esperados, sendo avaliada constantemente para que as suas ações sejam analisadas criticamente diante dos pontos fortes e das suas fragilidades.

Os atores desse planejamento não podem desistir da busca de uma educação de melhor qualidade no mundo do conhecimento, atentando para os aspectos relacionados à cultura, à realidade, à estrutura familiar e ao cotidiano do entorno em que a escola está inserida. Para a sua concretização são necessárias iniciativas transformadoras, persistência e principalmente boas relações no ambiente de trabalho.

Em toda ação humana observa-se que existe, mesmo que de forma implícita, um planejamento, visto que o ser humano é provido de razão e por consequência idealiza o seu "fazer". A escola enquanto instituição que tem como responsabilidade social a intervenção no processo educativo das pessoas deve planejar suas ações de forma eficaz para a busca da realização dos objetivos a que se propõe, buscando sempre a participação de toda a comunidade escolar.

De acordo com Villela (2011) o planejamento participativo é baseado nos princípios democráticos, cuja característica principal é a participação de todos os membros da comunidade escolar nos processo decisórios da escola. Nesse sentido é importante ressaltar que na elaboração de um planejamento participativo serão observadas todas as necessidades reais da escola, para que se tenha um ensino aprendizagem de boa qualidade e que seja significativo para todos.

Nessa perspectiva, é importante considerar alguns fatores que podem contribuir para a efetivação desse planejamento, tais como: a formação dos professores nas diversas áreas e especificações da educação, o 
currículo prescrito e o oculto, o ritmo de aprendizagem de cada aluno, a metodologia adequada para cada situação, a avaliação dialógica, as experiências advindas dos alunos, os valores, dentre outros fatores que contribuirão para a melhoria do clima e cultura organizacional da escola.

Segundo Libâneo (2004), o planejamento é uma prática de elaboração conjunta dos planos e sua discussão pública, é um processo de conhecimento e análise da realidade escolar em suas condições concretas, de busca de alternativas para solução de problemas e tomada de decisões.

Reportando-se ao fragmento acima, vale mencionar que a construção de uma escola de qualidade não é tarefa fácil, não se faz com "planejamentos relâmpagos" posto que para o alcance dessa escola, avanços e fracassos percorrerão a sua rotina e precisam ser avaliados de forma contínua.

Com referência a essa proposta, apresenta-se à contribuição de Luck (2000), quando define como planejamento estratégico o esforço disciplinado e consistente, destinado a produzir decisões fundamentais e ações que guiem a organização escolar, em seu modo de ser e de fazer, orientado para resultados, com forte visão de futuro.

A reflexão sobre esse tipo de planejamento permite reconhecer que na prática é preciso ter uma visão holística em relação a tudo que diz respeito à escola, não cabendo o planejamento funcional, que segundo Lück (2000), consiste no planejamento praticado a partir de uma visão fracionada o que apenas mascara a realidade, voltando sempre ao ponto de partida. Além disso, é importante que se considere a opinião dos segmentos da escola: gestão, corpo docente, discente e administrativo, pois são partes integrantes da comunidade escolar. Em alguns momentos a comunidade externa também precisa estar envolvida, pois as parcerias com outras instituições e com as famílias e fortalecerão as ações desenvolvidas na escola.

Com base nessas considerações sobre planejamento, a escola precisa se organizar enquanto instituição, pois a construção de seu projeto político pedagógico deve ser feita gradativamente e com a participação de todos, de forma a atender as necessidades reais de sua comunidade escolar. Além disso, a proposta curricular deve estar compatível com o perfil dos alunos, haja vista que o ensino-aprendizagem é a finalidade maior da escola.

A Lei de Diretrizes e Bases da Educação Nacional (Lei no 9.394/96) aponta possibilidades de organização do ensino, mas também sugere a adoção de outras possibilidades "sempre que o interesse do processo de aprendizagem assim o recomendar". Nessa assertiva, a flexibilidade deve ser observada sempre que se concluir o que é mais viável aos objetivos do processo ensino-aprendizagem.

\section{A IMPORTÂNCIA DA FORMAÇÃO CONTINUADA PARA DOCENTES E TÉCNICOS ADMINISTRATIVOS}

Dentre os fatores que fazem uma escola de boa qualidade destaca-se a formação de seus professores e a sua capacidade de interação em sala de aula com os seus alunos, possibilitando a assimilação de conteúdos que realmente vão ao encontro dos seus interesses, sentindo-se, assim, motivados para as aulas. Professores com esta perspectiva organizam o seu espaço, o seu tempo e o seu trabalho de forma planejada para obtenção de resultados positivos.

De acordo com a Lei de Diretrizes e Bases da Educação Nacional (Lei no 9.394/96) Art. 62:

A formação de docentes para atuar na educação básica far-se-á em nível superior, em curso de Licenciatura, de graduação plena em universidades e instituto superior de educação, admitida, como formação mínima para o exercício do magistério na educação infantil e nos cinco primeiros anos do ensino fundamental, a oferecida em nível médio na modalidade normal.

A esse respeito cabe a crítica reflexiva quando se pensa numa formação de professores que seja direcionada ao atendimento de todas as diversidades do contexto educacional. Não bastam formações de forma generalizadas, haja vista que a realidade do cotidiano escolar apresenta suas especificidades, requerendo, dessa forma, que o conhecimento seja multidimensional e que haja pesquisas que visem à melhoria para uma educação de qualidade. 
Segundo Paro (2001, p.10),

Não há dúvida de que podemos pensar na escola como instituição que pode contribuir para a transformação social. Mas, uma coisa é falar de suas potencialidades... uma coisa é falar "em tese, falar daquilo que a escola poderia ser.(...) outra coisa bem diferente é considerar que a escola que aí está já esteja cumprindo essa função. Infelizmente essa escola é sim reprodutora de certa ideologia dominante...é sim negadora dos valores dominados e mera chanceladora da injustiça social, na medida em que recoloca as pessoas nos lugares reservados pelas relações que se dão no âmbito da estrutura econômica.

No contexto escolar o trabalho do técnico administrativo é de fundamental importância, pois considerando que para uma gestão democrática não basta uma escola com condições físicas adequadas, currículos estruturados e professores sempre atualizados no campo de desenvolvimento científico, é preciso também que os técnicos administrativos, que também compõem o quadro de profissionais da educação, tenham oportunidades para formação continuada.

Chiavenato (2008), fala de desempenho:

Frente aos desafios para uma organização no trabalho, haja vista, que todos que atuam no processo educacional são responsáveis pelos resultados obtidos na comunidade escolar, é importante que o Técnico Administrativo enquanto trabalhador-educador se empodere de conhecimentos técnicos científicos para exercerem as suas funções no contexto escolar.

\section{RESULTADOS E DISCUSSÕES}

0 texto nos remete que para a construção de uma gestão democrática os desafios são muitos, não se trata apenas de resolver os problemas de burocracia, mas também compartilhar as responsabilidades de forma solidária, onde toda a comunidade escolar se empenha, também no sentido de desenvolver as capacidades cognitivas, afetivas e éticas dentro de um convívio saudável, acompanhando todos os possíveis fatores que interfiram de forma positiva para as mudanças necessárias.

Foi possível observar na revisão bibliográfica sobre a temática que se o clima da escola não favorece aos seus atores condições adequadas para um trabalho de boa qualidade, cabe à gestão uma reflexão voltada para o comportamento das pessoas, necessitando acompanhar o seu desempenho, como elas se sentem no trabalho, qual o nível de satisfação e como intervir junto à comunidade escolar para que todos se sintam bem neste espaço e assim possam contribuir para a sua melhoria.

É importante destacar a necessidade, ainda, da valorização de todos que formam o corpo da escola, reconhecendo o trabalho de cada um. Para isso, é preciso proporcionar um ambiente agradável, perceber a singularidade das pessoas, favorecer oportunidades de crescimento profissional e pessoal e entender que o esforço de cada um é que converge para a realização dos objetivos de toda a equipe e por consequência o sucesso da escola.

\section{CONCLUSÃO}

Em face ao exposto, pode-se concluir que o caminho para a melhoria do clima e cultura organizacional na escola se faz com o trabalho coletivo, com um planejamento participativo para uma construção sólida de uma escola de boa qualidade, para tanto deverão ser inseridas ações voltadas para uma gestão compartilhada onde serão levantadas e discutidas as questões técnico-pedagógicas, tais como propostas curriculares, formação continuada para docentes, gestores e pessoal administrativo dentre outros, sempre em busca de melhorias no processo de ensino-aprendizagem.

Por fim, todos os sujeitos envolvidos no trabalho administrativo e pedagógico de uma instituição de educação devem se organizar no sentido de construir a identidade do ambiente de trabalho escolar, criando condições favoráveis a uma boa relação interpessoal, onde há o respeito mútuo, a boa vontade, a aceitação e valorização dos pares em prol dos objetivos propostos e que causam interferência positiva na qualidade do processo ensino aprendizagem. 


\section{REFERÊNCIAS}

[1] Carneiro, Moaci Alves. LDB fácil: leitura crítico-compreensiva, artigo a artigo. 19ạ edição. Petrópolis, RJ: Vozes, 2012

[2] Chiavenato, Idalberto. Gestão de pessoas: o novo papel dos recursos humanos nas organizações. Rio de Janeiro: Elsevier, 2008.

[3] Griffith, J. School Climate as "Social Order" and "Social Action": A Multi-level Analysis of Public Elementary School Student Perceptions. Social Psychology of Education. V. 2.p.339-369, 1999.

[4] Libâneo, José Carlos. Organização e Gestão da escola - teoria e prática. São Paulo, Heccus, 2015.

[5] Libâneo, José Carlos; Oliveira, João Ferreira; Toschi, Mirza Seabra. Educação escolar: políticas, estrutura e organização. São Paulo: Cortez, 2013.

[6] Lück, Heloísa. A Aplicação do Planejamento Estratégico na Escola. Revista Gestão em Rede, no. 19, abril, 2000.p. 8-13.

[7] Maslow, A. B. Motivation and Personality. New York: Harper \& Brother, 1954.

[8] Murici, Izabela Lanna; Chaves, Neuza Maria Dias. Gestão para resultados na educação - Nova Lima: Falconi, 2013.

[9] Villela, Fábio Fernandes, Planejamento escolar Participativo e Estratégico. Disponível em: http://www.mutiraodesociologia.com.br/?tag=planejamento-participativo-e-estrategico Acesso em: 02 ago. 2015

[10] Paro, Vitor Henrique. Gestão democrática da escola publica. São Paulo: Ática, 2001.

[11] Pereira, F. A. de M.; Oliveira, Elane de; Teixeira, J. C. M. A influência do clima e cultura organizacional na gestão de uma escola do ensino fundamental. Qualit@s Revista Eletrônica, Vol.14, № 1, 2013. Disponível em: http://revista.uepb.edu.br/index.php/qualitas/article/viewFile/1521/925. Acesso em: 02 ago. 2015.

[12] Silva Junior, João dos Reis. Reforma do Estado e da Educação no Brasil de FHC - São Paulo: Xamã, 2002.

[13] Vergara, S.C. Projeto e relatórios de pesquisa em administração. São Paulo: Atlas Editora, 2014. 


\section{Capítulo 9}

Por outra imagem dos docentes e da docência na educação básica: O papel da formação continuada

\section{Maria dos Anjos Lopes Viella \\ Gislene Miotto Catolino Raymundo \\ Marizete Bortolanza Spessatto}

Resumo: Este artigo apresenta os dados de uma pesquisa que teve como objetivo investigar as expectativas dos professores da Educação Básica, atendidos pelo Centro de Referência em Formação e EaD, do Instituto Federal de Educação, Ciência e Tecnologia de Santa Catarina (IFSC), via programa Proforbas (Programa de Formação de Professores da Educação Básica), em relação à formação continuada oferecida pela instituição. 0 estudo teve como meta registrar as demandas de formação apontadas por esses professores a partir da realidade vivenciada por eles em seus contextos de atuação. Foram aplicados questionários com questões abertas e fechadas, para 201 professores e demais servidores pertencentes às redes municipais de ensino de oito municípios de Santa Catarina, em alguns encontros destinados à formação continuada. Buscou-se, com esse instrumento, identificar as demandas e levantar estratégias que permitam à formação continuada ser mais do que episódios de encontros de pares para "ouvir" um formador, passando a ser um momento de trocas de experiências que ressignifiquem a prática cotidiana. A análise dos dados foi feita à luz de autores como Arroyo (2000, 2004), André (2002), Nóvoa (2011) e Perrenoud (1993), entre outros, que tratam da formação de professores e seus percalços. Com a análise dos dados aqui apresentada, buscamos contribuir com esse debate destacando a forma como comparecem nas respostas a centralidade do reconhecimento dos alunos como sujeitos de direito ao conhecimento; o interesse e empenho dos professores em participar das formações e, por último, algumas inconsistências entre como os professores da educação básica são pensados e vistos e como se pensam e se veem.

Palavras-chave: Educação Básica. Formação continuada. Propostas de formação. 


\section{INTRODUZINDO 0 TEMA}

Somos a imagem que fazem de nosso papel social, não o que teimamos ser. Teríamos de conseguir que os outros acreditem no que somos. Um processo social complicado, lento, de desencontros entre o que somos para nós e o que somos para fora. Entre imagens e auto-imagens. (Arroyo, 2000, p.29).

Os caminhos revelados pelas pesquisas são surpreendentes. No caso que aqui descreveremos, na tentativa de mapear a formação dos professores das redes municipais da Educação Básica, levantar demandas de formação e a partir delas construir as propostas formativas, o quadro que se desvela traz algumas surpresas. Numa primeira leitura dos dados coletados com mais de 200 professores, começa a se nos impor uma certa "positividade" em relação a alguns aspectos da formação continuada, não apenas no bom sentido, mas no sentido do existente. Eles desvelam algumas faces do real que põem a nu outras imagens da docência nesse nível de ensino, encobertas sob camadas de discursos e análises que insistem em destacar o despreparo dos seus profissionais e, assim, eternizar imagens depreciadas do fazer docente. Essa forma negativa de se dirigir aos docentes, especialmente aqueles da Educação Básica, tem contaminado boa parte dos discursos divulgados pelas grandes mídias. Por que se tenta fixar um imaginário depreciativo sobre a docência?

Os resultados que visamos apresentar, aqui, apontam para outros caminhos. Se algumas formas de descrever os professores e sua formação pareciam mais propícias a desfigurá-los, insistimos com Arroyo (2004, p. 55) que "nosso olhar pode estar sendo reeducado". A forma de abordar o tema, neste trabalho, não foi cedendo lugar ao romanesco, mas revelando o trabalho dos professores sobre um ângulo não muito explorado comumente nas pesquisas. Essas revelações comparecem nos depoimentos dos 201 sujeitos ouvidos na caminhada que aqui se apresenta (professores e outros profissionais que atuam na Educação Básica de oito prefeituras de Santa Catarina) ${ }^{4}$.

Os dados coletados e analisados, além de fornecerem elementos para redimensionar questões curriculares e ações pedagógicas voltadas à Educação Básica e aproximar-se de abordagens pedagógicas alinhadas às demandas atuais em formação continuada de educadores, revela uma outra face desses profissionais, com tonalidades diferentes daquelas com as quais eles são sempre retratados. Também possibilitam, além de mapear o nível de titulação, de formação, (re)construir encaminhamentos para ofertar cursos que atendam às necessidades pedagógicas existentes no contexto escolar desses municípios pactuados.

Nessa direção, este texto traz, a seguir, alguns aspectos da formação continuada que se apresentam nas pesquisas, articulando-os ao diálogo com a formação almejada na perspectiva dos professores da Educação Básica. Depreende também dessa análise a centralidade do reconhecimento dos alunos como sujeitos de direito ao conhecimento e, por último, a forma sutil, como comparece nas análises das respostas, algumas inconsistências entre como os professores da Educação Básica são pensados e vistos e como se pensam e se veem.

Para melhor delinear uma imagem da docência e sair do filme em negativo, apontando outras tonalidades que vão sendo acrescentadas no cotidiano de trabalho desses sujeitos, é necessário partir de dentro da docência, dar voz ao professor. 0 que surge é uma fotografia revelada por outros flashes que apontam para ângulos pouco explorados e que ficam encobertos com uma imagem da docência carregada de lacunas.

\section{AS PESQUISAS SOBRE FORMAÇÃO CONTINUADA E A FORMAÇÃO CONTINUADA NA PERSPECTIVA DOS PROFESSORES DA EDUCAÇÃO BÁSICA: QUAL DIÁLOGO?}

Falar sobre formação continuada parece não acrescentar grandes novidades em relação às pesquisas educacionais.

\footnotetext{
4 Esses municípios foram pactuados para serem atendidos pelo Proforbas (Programa de Formação para a Educação Básica), ofertado pelo Instituto Federal de Educação, Ciência e Tecnologia de Santa Catarina (IFSC). São eles: Canelinha, Capivari de Baixo, Palhoça, Pedras Grandes, Pescaria Brava, São José, Tubarão e Turvo. Nesses municípios, por meio desse programa, são ofertados os cursos de "Práticas Pedagógicas" e "Dificuldades de Aprendizagem", ambos com carga horária de 60 horas.
} 
Vários autores trazem suas reflexões sobre o tema, ora apontando as "práticas inovadoras realizadas e analisadas, oferecendo repertório para repensar as políticas e práticas vigentes" (Gatti, 2012, p.439) ora discutido o termo "educação continuada" (Gatti, 2008, p.57) e alguns programas que se abrigam sob esse rótulo. Quanto ao financiamento, alguns projetos são apoiados pelos poderes públicos municipais ou estaduais, bem como a multiplicação das ofertas de educação continuada e as preocupações quanto à criteriosidade, validade e eficácia desses cursos, as avaliações dessas ações (p. 61), menção de alguns documentos internacionais que enfatizam a necessidade dessa formação, especialmente alguns documentos do Banco Mundial, da UNESCO etc.

Pesquisa feita por Mediano (1992), observando práticas escolares, traz alguns dados sobre a formação continuada que apontam:

[...] uma certa aversão por parte dos professores em relação aos pacotes de treinamento a que periodicamente são submetidos, por decisão dos órgãos centrais dos sistemas educacionais, ao mesmo tempo em que percebemos algumas práticas dentro da própria escola, emergindo de seus próprios atores e que pareciam ter impacto no trabalho dos professores e na qualidade do ensino que impartiam com seus alunos. (Mediano, p.31, 1992). 38434.

André (2002, p.172), na Série Estado do Conhecimento sobre a formação de professores no Brasil (19901998), traz muitas contribuições para se refletir sobre o processo de formação continuada. Na literatura por ela visitada, apresenta vários autores que fornecem a base para esse conceito de formação continuada como prática reflexiva e autores que além de incluírem os pressupostos destacados na formação continuada como prática reflexiva, também procura visualizá-los em integração com o contexto sóciopolítico-econômico-cultural mais amplo.

Uma contribuição fundamental para essa pesquisa vem de Mediano (apud André 2002, p. 174) ao destacar:

a necessidade de [...] um trabalho conjunto que discuta a prática pedagógica e busque soluções para os problemas a partir da adoção de três princípios básicos: converter as próprias experiências em situações de aprendizagem; fazer uma reflexão crítica da própria prática; e orientar a análise e o estudo de problemas diagnosticados na escola, considerada em sua inserção no contexto social mais amplo.

O percurso feito por André (2002) ressalta inúmeros aspectos da formação continuada que não poderão ser ignorados em qualquer proposta nessa direção, tais como: avaliar os autores que criticam "as estratégias de formação continuada propostas de forma vertical, como cursos, seminários, vivências, etc" (p.172); considerar a discussão sobre "a identidade profissional do professor e sua construção como sujeito historicamente situado e, nessa construção, a mobilização dos saberes da docência (saberes da experiência, saberes científicos e saberes pedagógicos)" (p.174).

Concorda-se com a crítica de Kramer (apud André, 2002, p.178) aos "pacotes de treinamento" - baseados na concepção do "efeito multiplicador" ou "efeito de repasse" através de instâncias intermediárias (especialistas que repassam aos professores) -, que têm acarretado baixa ou nula compreensão das propostas, aversão à inovação, etc., assim como contra os chamados "encontros de vivência", que, centrando-se em aspectos socioafetivos, se revelam superficial. Concorda-se ainda com Alves (apud ANDRÉ, 2002, p.174) que o conceito de capacitação docente deve contemplar, de forma interligada:

1) a socialização do conhecimento produzido pela humanidade; 2) as diferentes áreas de atuação; 3) a relação ação-reflexão-ação; 4) o envolvimento do professor em planos sistemáticos de estudo individual ou coletivo; 5) as necessidades concretas da escola e dos seus profissionais; 6) a valorização da experiência do profissional. Mas, também: 7) a continuidade e a amplitude das ações empreendidas; 8) a explicitação das diferentes políticas para a educação pública; 9) o compromisso com a mudança; 10) o trabalho coletivo; 11) a associação com a pesquisa científica desenvolvida em diferentes campos do saber. 
Nas falas dos professores cursistas alguns desses aspectos aparecem de forma bem visível, outros remetem mais diretamente às ações dos formadores das instituições que ofertam a formação continuada sinalizando a necessidade de diálogo permanente desses dois sujeitos do processo formativo. A associação com a pesquisa científica desenvolvida em diferentes campos do saber vai ao encontro da contribuição de Demo (apud ANDRÉ, 2002, p.177) para se pensar a formação continuada incorporando-se a pesquisa como princípio educativo, aliada à competência para intervir sobre a realidade com base nos conhecimentos produzidos.

As propostas de formação continuada, no contexto do "Estado do Conhecimento" realizado por André (2002), convergem para as análises que emergem dos dados coletados na pesquisa que gerou este artigo. Os saberes da experiência, saberes científicos, saberes pedagógicos aparecem repetidas vezes nos discursos dos profissionais pesquisados, anunciando a necessidade dos mesmos comparecerem nas propostas formativas de forma articulada. A forma como aparecem nas falas dos professores ora enfatiza os saberes da experiência, ora os saberes científicos, ora contemplam apenas dois deles, revelando a urgência da ressignificação dos saberes na formação de professores e sua necessária articulação, pois conforme coloca Pimenta (apud André ,2002, p.178) "Os futuros professores poderão adquirir saberes sobre a educação e sobre a Pedagogia, mas não estarão aptos a falar em saberes pedagógicos sem constituir o seu saber-fazer a partir do seu próprio fazer.

Cabe aqui destacar o devido cuidado que se deve ter quando se fala em saberes da experiência e da relevância das histórias de vida na formação dos professores, para que não se corra o risco de subsumir nesse discurso o conhecimento científico, o conhecimento educacional e ignorar o alerta dado por Dias-daSilva (2008, p. 425) quanto ao perigo da "glorificação dos saberes docentes e a minimização do conhecimento educacional”. Nessa direção Dias-da-Silva (2008, p. 434 ), afirma:

Estou convencida de que a profissionalização exige dos professores inúmeros conhecimentos que precisam ser dominados para a construção da intelectualidade que o trabalho docente exige! Não basta treiná-los em serviço para uso de novas tecnologias de ensino ou colocá-los ao redor de uma mesa para discutirem e 'refletirem' sobre sua experiência vivida. Os professores precisam se apropriar de muito mais conhecimentos sobre a realidade social $e$ escolar para interpretarem sua "prática" - desde analisar as implicações do modelo neoliberal para a concepção de educação até desvendar e interpretar as culturas jovens, suas tribos e ritos; desde analisar criticamente a sociedade desigual em que vivem até desvendar a contribuição do conhecimento científico para a interpretação de seus hábitos e práticas; desde decifrar as novas fontes de informação e seus mecanismos até a contribuição da arte como possibilidade de enfrentamento da violência que perpassa nosso cotidiano; desde conhecer profundamente os processos de raciocínio e pensamento dos alunos até dominar processos e modalidades de construção de um leitor crítico, etc. Todos esses aspectos implicam domínio do conhecimento educacional - suas teorias, pesquisas e estudos, seus autores clássicos e contemporâneos, suas análises e interpretações, suas hipóteses e teses. Conhecimento racionalmente construído, que permita interpretar os homens, suas sociedades e culturas, seu pensar e seu agir. Conhecimento que pressupõe a palavra temida: teoria. A apregoada "prática" precisa ser interpretada historicamente, filosoficamente, sociologicamente, psicologicamente, politicamente, pedagogicamente. Do contrário, qual a diferença entre uma professora e uma babá semi-analfabeta?

Toda essa reflexão sobre os saberes da docência e a necessidade de fundamentá-los teoricamente anuncia práticas para as propostas de formação continuada. Esse exercício da urgente articulação entre saberes da docência e conhecimento científico é condição sine qua non da formação docente. De certa forma essa demanda aparece na fala dos professores cursistas, mas essa dimensão entre saberes e conhecimentos e a devida articulação entre eles é que precisa ganhar corpo no processo formativo. Quando os professores/cursistas foram questionados sobre qual a expectativa em relação ao curso de formação continuada, "adquirir conhecimentos" (com as variações "obter", "agregar", "aprender") foi a categoria mais evidenciada. 
Nas respostas à questão, dos 201 questionários analisados, 125 deles indicaram a expectativa de que o curso possibilitasse "adquirir, atualizar informações sobre práticas pedagógicas, apropriar-se de novos conhecimentos e desenvolver métodos a serem trabalhados" (professor Ensino Fundamental - 1ํㅜ ao 5ํㅜ ano, Turvo ${ }^{5}$.

Os depoimentos evidenciam um professor preocupado com a necessidade de aprofundamento teórico e conceitual sobre os processos de ensino e de aprendizagem ("mais conhecimento e atualização da prática pedagógica" - professor EF 1ํo ao 5ํano, Turvo; "Adquirir conhecimentos aprofundados da área" - prof. EF 10 ao 50 ano, São José) para qualificar as ações em sala de aula ("Adquirir mais conhecimento para o dia a dia” - auxiliar de Educação nas séries iniciais, Turvo; "Adquirir novas práticas pedagógicas para auxiliar em nosso trabalho em sala de aula" - prof. Educação Infantil, Canelinha); "Aprender mais e aprofundar leituras através de bibliografias sugeridas"-prof. do Ensino Fundamental 1o ao 5o e 6o ao 9oㅡ, Capivari de Baixo).

Embora o número seja menos significativo quantitativamente (pouco mais de dez respostas remeteram à questão), é importante destacar que, ainda na resposta a essa questão, os professores reforçaram o que em muito as pesquisas têm evidenciado: a necessidade de trocas de experiências exitosas para qualificar a prática pedagógica. Também é possível "aprender" a fazer diferente em sala de aula partilhando aquilo que deu certo em experiências desenvolvidas pelos pares: "Adquirir conhecimento compartilhando e trocando experiências com os colegas e docentes cursistas" (prof. da Educação Infantil ao 9o ano, Palhoça); "Ampliar prática pedagógica, compartilhar atitudes e conhecimentos" (prof. EF 1o ao 5o ano, Pedras Grandes).

Analisando as respostas dadas pelos professores/cursistas ${ }^{6}$ à questão que oferecia a possibilidade de apontar sugestões de novos cursos oferecidos pelo instituto federal proponente da formação continuada, observa-se que, novamente, revela-se a preocupação dos professores com a formação teórica, mas, sobretudo, com a possibilidade de experienciar atividades práticas para serem desenvolvidas em sala de aula. Vinte e quatro professores sugeriram que as ações futuras do IFSC na formação ofertada em parceria com as redes municipais fossem voltadas ao uso de atividades lúdicas e jogos em sala de aula. Outros 20 professores indicaram propostas de cursos que tratassem de metodologias de ensino e didática (alguns especificaram as suas áreas de atuação, como história, matemática e ciências), nove indicaram como opção cursos envolvendo práticas pedagógicas e outros 23 indicaram ações de formação específicas em contação de histórias, musicalização, dança para educação infantil, confecção de brinquedos, dobraduras e origamis. Essas manifestações dos professores expressam o desejo de ações de formação que tenham como centro o que eles próprios apontaram como a necessidade da formação continuada, que é qualificar a prática para assegurar o envolvimento e o aprendizado dos alunos.

O que se vê reiteradas vezes é a necessidade de aperfeiçoamento, atualização, mas sempre atrelada a melhorar o desempenho em sala de aula, ensinar mais e melhor. Enfatizam a necessidade da teorização, mas sem tornar os cursos cansativos.

Alvarado-Prada, Freitas e Freitas (2010), apresentam dados coletados em pesquisa na região de Uberaba, com 748 professores de 23 municípios e que se aproximam bastante das respostas dos sujeitos dessa pesquisa. Para Alvarado-Prada, Freitas e Freitas (2010, p.378).

as ações que os professores mais gostaram foram as oficinas, mesmo sendo pouco ofertadas ou pouco desenvolvidas nas ações de formação. Eles justificam seu gosto, por elas apresentarem formas variadas de trabalhar, dinâmicas, debates sobre a conduta dos docentes em sala de aula enquanto prática de ensino, metodologia participativa, afirmando, assim, que na prática se observa melhor a realidade e o aprendizado é através de coisas concretas. Também gostaram das palestras e seminários, tendo em conta que nesses encontros se discutem temas considerados relevantes no exercício da profissão, porém, essas palestras, em geral, são consideradas cansativas e repetitivas, o palestrante normalmente é despreparado quanto ao contexto escolar, e faz pouca relação teoria e prática. Os docentes enunciam que os cursos são ações frequentemente oferecidas como formação continuada, entretanto não agradaram os professores pelo fato de caracterizarem uma imposição, na maioria das vezes,

\footnotetext{
${ }^{5}$ Omitimos os nomes dos professores e das escolas em que atuam para preservar a identidade desses sujeitos.

${ }^{6}$ Muitos indicaram mais de uma opção.
} 
pelas secretarias de educação. Alguns dizem que não são de real interesse; por serem mais exposições de temas do que conteúdos que vão ao encontro das expectativas dos docentes, pois estes, em sua maioria, querem conteúdos e metodologias para resolver situações do seu cotidiano. Buscam, nas ações de formação continuada, ajuda para resolução de problemas, a transformação de sua prática e o cotidiano da sala de aula.

Tudo isso coloca também a urgência de dar voz ao professor. Entre as temáticas sugeridas para novos cursos também apareceram como destaque a preocupação com o processo de avaliação da aprendizagem (indicado em 14 respostas), o ensino de língua materna, a alfabetização e o letramento (indicado em 29 respostas) e educação especial. Essa última temática aparece na fala de 48 professores, nos municípios de Capivari de Baixo, Canelinha, Tubarão e Turvo. Essa recorrência aparece na fala dos 38 docentes que desempenham o papel de segundo professor, isto é, aquele que atende alunos que fazem parte do programa de inclusão escolar, mas também na fala de professores titulares de turma. Isso revela a urgência de ampliar a formação nessa direção.

As teses de culpabilização dos professores e de sua má formação pelas mazelas do ensino e da vitimização dos alunos pelo sistema educacional perverso e excludente, não poderão encobrir o forte desejo dos professores, manifesto nessa pesquisa, pela sua formação, e atualização, bem como o desejo de compartilhar experiências, mas também contribuir, pois não se pode ignorar que são professores habilitados para essa função. As teses de culpabilização e vitimização também escondem, camuflam a falta de reconhecimento social dado a educação e aos tempos de vida que esses docentes formam. Esse aspecto será brevemente tratado a seguir.

\section{0 LUGAR DOS ALUNOS COMO SUJEITOS DE DIREITO AO CONHECIMENTO}

Pode parecer óbvio que nas pesquisas feitas com professores, especialmente aquelas de formação continuada, a aprendizagem dos alunos ou mesmo preocupações com alguns aspectos que envolvem a relação professor-aluno, compareçam como categoria central nos discursos, mas essa centralidade não é algo tão dado assim. Pesquisa de André (2002, p. 31), sobre os aspectos emergentes no Estado do Conhecimento da formação de professores, afirma, que o processo de produção de conhecimentos do aluno e suas expectativas e representações vêm ganhando crescente atenção. "Verifica-se que a preocupação com o processo de aprendizagem do aluno emerge, ainda que timidamente, no contexto da produção de textos".

Analisando as respostas dadas pelos professores/cursistas quanto as expectativas em relação ao cursos ofertados pelo IFSC, ou mesmo quais conteúdos gostariam de ver contemplados nos cursos ou ainda sugestões de cursos/temas que mais os ajudariam, a referência à preocupação com o aluno e sua aprendizagem, aparece nas respostas de 120 professores/servidores municipais.

É Arroyo (2000) que pode nos auxiliar nessa direção. Embora defenda a necessidade de repor os mestres no lugar de destaque que lhes cabe, tirando-os do segundo plano, insistimos que também precisamos repor os alunos num lugar de destaque nos discursos sobre a escola.

Muito mais que as teorias, as políticas, o currículo e a própria escola, estão os sujeitos, educadores e alunos.

$\mathrm{Na}$ apresentação de seu livro Ofício de mestre: imagens e auto-imagens, ele nos provoca:

Quando pensamos na saúde de nossos filhos ou da infância, não pensamos no hospital, mas no médico. Saúde nos lembra os médicos. Educação nos lembra a escola, não seus profissionais, os educadores. Estes não conseguem ser a referência, mas a instituição escola. [...] Houve no imaginário sobre a educação uma despersonalização que não acontece em outros campos sociais. (Arroyo, 2000, p.10).

Vemos nas respostas dos professores / cursistas a centralidade dada ao aluno e à sua aprendizagem. Se analisadas outras respostas além daquelas que mencionam a categoria aluno e/ou crianças, pode-se afirmar que a quase totalidade das respostas convergem para o aluno como o sujeito com direito ao conhecimento, conforme segue: "melhorar a qualidade do meu trabalho" e "encontrar saída, ajudar a trabalhar com as crianças com dificuldades de. aprendizagem (Prof da Educação Infantil-Capivari de Baixo); Identificar as dificuldades de aprendizagem e saber como agir" (Prof. do Ensino Fundamental 1ํo ao 5o -São José); melhorar a postura do educador frente as novas gerações (Prof. Educação Infantil ao 9o ano- 
Palhoça); "melhorar cada vez mais a teoria e a prática para sanar as dificuldades encontradas em sala" (Prof. do Ensino Fundamental 1o ao 5--Turvo); "Quero ensinar respeitando a individualidade de cada um, na sua dificuldade em aprender" (Prof. do Ensino Fundamental 1 ao 5o e 6o ao 9o-Tubarão); "Aprimorar mais os conhecimentos para desenvolver uma melhor prática pedagógica” (Prof. de Educação InfantilPedras Grandes); “Quero absorver novas experiências e conhecimentos que melhorem e renovem a minha prática pedagógica” e (Prof. da Educação Infantil-Canelinha); "aprofundar meu conhecimento para que eu possa aplicá-lo em sala de aula, assim tornando o ensino mais dinâmico." (Prof. do Ensino Fundamental $6^{0}$ ao 9 o e Ensino médio- Canelinha).

Pelo exposto na fala desses professores e servidores em geral, os alunos são recuperados enquanto sujeitos e existe uma preocupação real com a superação das dificuldades de aprendizagem, mas como coloca Arroyo (2000,p.31) "nos definimos por recortes de docência ou pelos tempos da vida que formamos" assim, atribuir à culpa dos problemas da escolarização à má formação dos docentes ou tomálos como vítimas da situação social e educacional, não ajuda a compreender que o trabalho docente é síntese de múltiplas determinações e que o reconhecimento social dos tempos da vida que formam está intimamente atrelado ao reconhecimento social que possuem. Outros fios compõem essa complexa história da docência.

\section{COMO OS PROFISSIONAIS DA EDUCAÇÃO BÁSICA SÃO PENSADOS E VISTOS E COMO VEM SE AFIRMANDO.}

A necessidade de trazer mais uma vez em cena o professor da Educação Básica é decorrente de uma certa insatisfação reinante no cotidiano do trabalho escolar, quanto às formas usuais de se falar sobre ele. Na maioria das vezes ele é sempre fotografado sob o prisma de um rol de competências que precisa possuir para se constituir enquanto tal, estabelecendo-se um leque extenso de competências desejáveis, ou ainda, é definido na sua negatividade a partir daquelas competências que não tem. Zeichner (1998, p.210) afirma que uma "razão para a falta de entusiasmo dos professores para a pesquisa acadêmica sobre a educação é a freqüência com que eles se veem descritos de forma negativa". Este olhar sufoca outros traços que revelam o professor de corpo inteiro.

Muitas vezes, o discurso que sustenta a necessidade da formação continuada abriga uma face perversa do ser professor pelo fato de sinalizar para um profissional onipotente, um semideus, acima de todas as condições materiais e de contexto onde se exerce a docência.

Como escreve David Labaree (apud Nóvoa, 2011, p. 52), “as práticas docentes são extremamente difíceis e complexas, mas, por vezes, alimenta-se publicamente a ideia de que ensinar é muito simples, contribuindo assim para um desprestígio da profissão.

Segundo Arroyo (2000, p.34)

Escreve-se muito sobre o professor que queremos, sobre como formá-lo e assumi-lo, como se estivéssemos diante de um profissional sem história. Um modelo novo a ser programado. Um profissional que podemos fazer e desfazer a nosso bel-prazer, com novos traços definidos racionalmente pelas leis de mercado, pelas novas demandas modernas [...] Tracemos um novo perfil e ele se imporá daqui para frente. [...] Parecem nos dizer: esqueçam o que são e sejam o docente que propomos, que arquitetamos e queremos. [...] Uma vez configurados os novos traços e o novo perfil de profissional, apenas restará encontrar o programa, o currículo e a instituição mais adequados a sua comformação.

Realizar a formação de professores supõe conhecer bem a realidade das escolas, os malabarismos que os professores precisam fazer para participar das formações. Como coloca Nóvoa (2011, p.22).

É inútil apelar à reflexão se não houver uma organização das escolas que a facilite. É inútil reivindicar uma formação mútua, inter-pares, colaborativa, se a definição das carreiras docentes não for coerente com este propósito. É inútil propor uma qualificação baseada na investigação e parcerias entre escolas e instituições universitárias se os normativos legais persistirem em dificultar esta aproximação.

Perrenoud (1993, p.199) pergunta: "É possível desconhecer que uma parte dos professores não sente necessidade de se formar"? Esse não parece ser o caso dos professores cursistas, pois quando indagados 
pelo motivo de estarem fazendo o curso, 143 deles afirmaram ser por opção pessoal, 56 para progressão na carreira e apenas 2 afirmaram ser por obrigação institucional. 0 argumento que Perrenoud (1993, p.199) utiliza é que os professores.

pensam que o saber-fazer pedagógico é uma questão de dom ou experiência e não acreditam que os psicopedagogos, metodólogos e outros especialistas possam dar-lhes qualquer ajuda. Estes professores protegem-se da formação em nome de uma concepção de profissão que nega o seu próprio sentido.

E, referindo-se especificamente à formação continuada, Perrenoud (1999, p. 199) afirma que "quando ela é facultativa, há quem a ignore totalmente; quando é obrigatória, nada.

impede que se leia o jornal ou se durma num seminário" (p.199). Em relação aos cursistas dessa pesquisa, percebe-se pelas respostas o quanto eles apreciam esses processos formativos, talvez por atuarem nos municípios do interior do Estado e as possibilidades de acesso às formações serem mais limitadas. Mesmo assim eles manifestam a "necessidade de envolver mais professores" (Prof. do Ensino Fundamental, 6oa 9o ano, Palhoça), destacam a importância do curso para desenvolver a autoestima, pois um professor motivado, com certeza terá alunos motivados". (Canelinha, ens. Fund. 1o ao 5ํㅜ). Nesse espaço cabe ainda considerar que 30 desses profissionais possuem 2 jornadas de trabalho, 3 atuam em três etapas da Educação Básica (1ํo ao 5ํo ano, 6o ao 9o e Ensino médio e um (1) deles atua em 4 etapas (Ens. Fund. 1ํo ao 5; 6ำ ao 9o; Ensino médio e auxiliar de Ed. Inclusiva).

Se essa diversidade do público que participa desses cursos é um complicador para a formação, haja vista a necessidade de um planejamento que busque contemplar boa parte das demandas, essa mesma diversidade anuncia também o interesse dos municípios em propiciar essa formação incentivando a participação e a disposição dos professores em se envolver algumas vezes, numa tripla jornada.

Dos 201 profissionais participantes do curso, 33 possuem magistério ou formação em nível médio; 90 possuem Licenciatura; 61 possuem Especialização, 11 outros cursos da área da educação e 5 possuem Mestrado e/ou doutorado.

Assim, é possível admitir, que insistir no discurso da má formação dos professores, é destacar apenas uma parte da história. 0 tema da formação do educador não pode ser pensado isolado do tema como se "deforma" o educador e também não pode ser desarticulado das propostas sociais de formação e conformação do humano.

\section{CONCLUSÕES SEMPRE PROVISÓRIAS}

Os dados coletados possibilitam pensar em novas propostas formativas e colocá-las em ação priorizando especialmente as trocas de experiências entre os pares, além de destacar tonalidades do fazer docente, muitas vezes negligenciadas nas pesquisas, mas muito presentes na voz dos professores cursistas: uma imagem positiva do seu fazer, uma consciência de domínio de muitos conteúdos necessários à docência com possibilidade até de ser partilhada entre os pares para melhoria do ensinar. Fica muito visível a forma como esses sujeitos percebem o processo formativo, revelando nas respostas a incompletude e o inacabamento dessa formação, apresentando-se muito abertos e receptivos a novas aprendizagens e atualização. A preocupação central com a aprendizagem do aluno, com a necessidade de criar, inovar, buscar novas formas de atuação que motivem, impulsionem o aluno, aparecem reiteradas vezes, ilustrando um compromisso com o trabalho. Não se trata de idealizar esses sujeitos e suas práticas, numa assepsia total de insucessos e contradições que são difíceis de ultrapassar, mas falar do existente, num possível onde o professor se revela além das lentes das mídias e dos discursos que mais os enclausuram que os libertam dessas imagens desqualificadas da docência na educação básica.

Nóvoa (2011, p.16) recordando o aviso premonitório de David Labaree coloca que "os discursos sobre a profissionalização dos professores tendem a melhorar o estatuto e o prestígio dos especialistas (formadores de professores, investigadores, etc.) mais do que a promover a condição e o estatuto dos próprios professores".

É preciso mergulhar no estudo e compreensão do contexto no qual se encontram disseminadas algumas imagens sobre a docência, sobrepondo-se a outras. As falas dos sujeitos dessa pesquisa revelam aspectos de algumas aventuras pedagógicas do ofício de mestre que rompem os estreitos limites dos quadros onde esses mestres são cotidianamente enquadrados. Entre imagens e autoimagens é possível vislumbrar outros horizontes para a formação continuada. 


\section{REFERÊNCIAS}

[1] Alvarado-Prada, Luis Eduardo; Freitas, Thaís Campos; Freitas, Cinara Aline. Formação continuada de professores: alguns conceitos, interesses, necessidades e propostas. Rev. Diálogo Educ., Curitiba, v. 10, n. 30, p. 367 387, maio/ago. 2010.

[2] André. Marli Eliza Dalmazo Afonso de. Formação de professores no Brasil (1990-1998). Brasília : MEC/Inep/Comped, 2002. (Série Estado do Conhecimento, n. 6).

[3] Arroyo, Miguel G . Ofício de mestre: imagens e auto-imagens. Petrópolis, RJ: Vozes, 2000.

[4] Arroyo, Miguel G. Imagens quebradas: trajetórias e tempos de alunos e mestres. Petrópolis, RJ: Vozes, 2004.

[5] Dias-da-Silva, Maria Helena G. F. A fragilização da escola pública, a glorificação dos saberes docentes e a minimização do conhecimento educacional. Trajetórias e processos de ensinar e aprender: práticas e didáticas - XIV Endipe. Porto Alegre, 2008.

[6] Freitas, Helena C.L. Formação de professores no Brasil. 10 anos de embate entre projetos de formação. Educação e Sociedade, Campinas, vol. 23, n. 80, setembro/2002, p. 136-167.

[7] Gatti, Bernardete A. Análise das políticas públicas para formação continuada no Brasil, nas últimas décadas. Revista Brasileira de Educação. v. 13 n. 37 jan./abr. 2008. p.57-70.

[8] Gatti, Bernardete. Formação de professores e profissionalização: contribuiç̃oes dos estudos publicados na Rbep entre 1998 e 2011. R. bras. Est. pedag., Brasília, v. 93, n. 234, [número especial], p. 423-442, maio/ago. 2012.

[9] Mediano, Zelia D. A Formação em Serviço do Professor, a partir da Pesquisa e da Prática Pedagógica. Tecnologia Educacional. RJ. Vol. 21. Março/Junho. 1992.

[10] Nóvoa, António. O regresso dos professores. Pinhais: Melo. 2011.

[11] Prada, L. E. Alvarado. Formação continuada de professores: experiências em alguns países. Rev. Online da Bibl. Prof. Joel Martins, Campinas, v.2, n.3, p.97-116, jun. 2001.

[12] Perrenoud, Philippe. Práticas pedagógicas, profissão docente e formação: perspectivas sociológicas. Dom Quixote: Lisboa/Portugal, 1993.

[13] Zeichner, K. M. Para além da divisão entre professor-pesquisador e pesquisador acadêmico. In: Geraldi, Corinta M.G; Fiorentini, Dario e Pereira, Elisabete M. de Aguiar (orgs.). Cartografias do trabalho docente: professor(a)pesquisador(a). Campinas, SP, Mercado de Letras: Associação de Leituras do Brasil, Alb, 1998. 


\section{Capítulo 10}

\section{Prática de narrativas e memórias através de um olhar docente}

\section{Ana Lúcia Ferraz}

Resumo: 0 presente artigo é o resultado de um mestrado em andamento que teve como título prática de narrativas e memória (o ensino de História) a partir de um olhar docente. Para desenvolver as práticas de memória as temáticas africanas foram elaboradas dentro do planejamento anual segundo as deterioração educacionais da Secretaria da Educação de São Paulo. Um dos avanços conquistados com minhas turmas posso notar através do cotidiano escolar no qual posso notar alunos de "etinias" diferentes mas com propósitos semelhantes fazer a diferença e buscar uma sociedade com igualdade e justiça. A Instituição Doutor Reynaldo do Nascimento Falleiros vem pondo em prática a Lei 10.639/03 o que acarreta uma melhoria na qualidade de ensino e de interação social.

Palavras chave: Cultura; Docente; Narrativas; Memória. 


\section{INTRODUÇÃO}

A escola Doutor Reynaldo do Nascimento Falleiros está localizada na região metropolitana de São Paulo no Município de Taboão da Serra e tem 1.200 alunos matriculados em três turnos e as turmas que ministro nas aulas de História são alunos do período matutino e noturno e tem faixa etária dos treze aos dezoito anos.

Segundo Kabengele 2005:

“O resgate da memória coletiva e da história da comunidade negra não interessa apenas aos alunos de ascendência negra. Interessa também aos alunos de outras ascendências étnicas, principalmente branca, pois ao receber uma educação envenenada pelos preconceitos, eles também tiveram suas estruturas psíquicas afetadas. Além disso, essa memória não pertence somente aos negros." (Kabengele, 2005, p. 16)

Para o determinado trabalho que foi elaborado e concluído como capítulo integrado da Dissertação de Mestrado que está em fase de conclusão foi escolhido um grupo focal de 78 alunos os quis se reconhecem afrodescendentes. As três temáticas utilizadas: gráfico representativo, gráfico de História da Abolição e Memória de infância e vida são as temáticas que venho inserindo em minhas aulas. De acordo com Le Goff 2013, as reminiscências são frutos de experiências que seguem uma cronologia, porém, a nossa "memória" enquanto fato histórico também podem se tornar "atemporal" quando analisamos nossos sentimentos que muitas vezes carregam, emoção, tristeza, alegria, etc. E é no despertar do tempo que estes sentimentos atemporais podem se tornar coletivos quando estes se tornam documentos ou objetos e até mesmo monumentos. Para tais práticas as turmas do nono A e de ensino médio participaram de dinâmicas que necessitou de um olhar docente assim como nas outras turmas.

\section{OBJETIVO GERAL}

O determinado trabalho tem como objetivo disseminar práticas de cultura africana em sala de aula.

\section{OBJETIVO ESPECÍFICO}

Propiciar temáticas de cultura africana enriquecendo o currículo escolar.

\section{METODOLOGIA}

Para inserir práticas de cultura africana e valorização da História de povos afrodescendentes foram elaboradas temáticas diferenciadas para as referidas turmas:

1 - Nono ano A - Pesquisa sobre grupo étnico e construção de gráfico representando a etnicidade da turma com 38 alunos;

2 - Relatório de pesquisa sobre memória e narrativa de infância e História de vida, turma de 30 alunos do $3^{\circ} \mathrm{A}$;

3 - Representação gráfica dos períodos Pré, Pós e Abolição, "racismo", trabalho realizado com turma do 2ํㅡㄴ A com 36 alunos.

\section{DISCUSSÃO}

Para a turma do nono A, foram elaboradas as seguintes perguntas:

1 - A que grupo étnico pertenço?

() branco ( ) negro ( ) afrodescendente

2 - Como assuntos de racismo são resolvidos no meu círculo racial?

( ) através da conversa ( ) ignorado ( ) leio sobre o assunto 
3 - Em relação a família são:

( ) negros () brancos () amarelos ( ) indígenas

4 - As mudanças com a Lei 10.639/2003 me causaram:

( ) tranquilidade ( ) espanto ( ) indignação ( ) não mudou nada

\section{RESULTADO}

A sala (turma do segundo ano A) é bem heterogênea, porém são tranquilos e as aulas de História no bimestre vigente tem por objetivo (estudar) temáticas de Cultura brasileira e africana e o contexto do Brasil dos séculos passados. 0 quadro o qual foi analisado tem as seguintes características. Gráfico de Pré, Pós e Abolição.

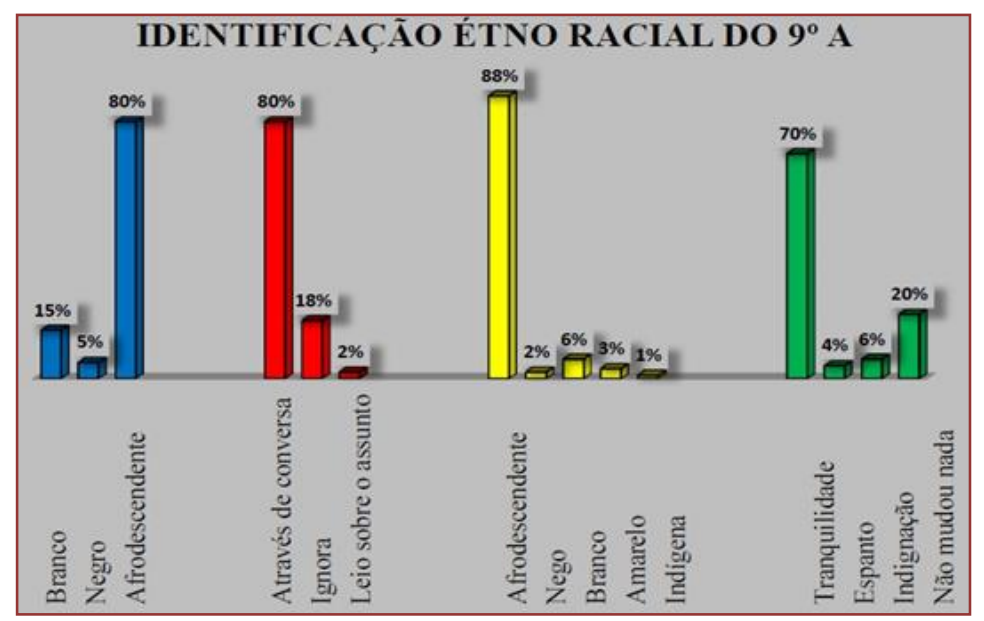

\section{Livia Almeida}

Sabe-se que o texto fala sobre o preconceito que o governo do nosso país tinha no ano de 1888 em diante, querendo assim branquear o país, proibindo a entrada de "não brancos" no país, tendo um pensamento de que as pessoas não brancas, pardas e indígenas, poluem e levam o país para baixo, que é a culpa deles o país ter os seus "defeitos".

Esse conceito que eles tinham de que os negros e pessoas de cor, eram piores que as brancas, tendo esse preconceito todo, pois é um pensamento sem fundamento.

\section{Vitória Vieira da Silva}

Gráfico imigrantes entrando no Brasil (1889-1930)

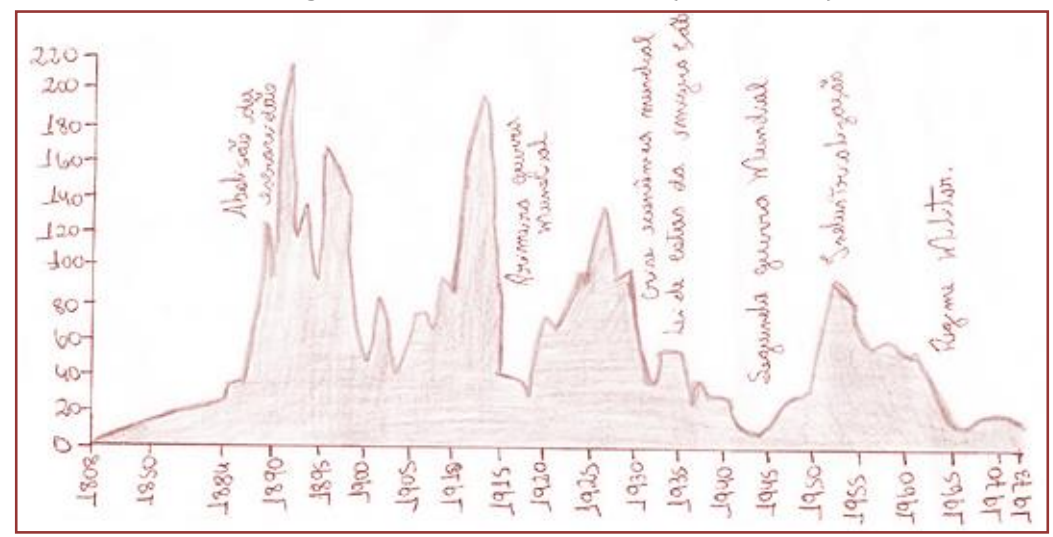




\section{COMENTÁRIO/CRÍTICO}

0 gráfico mostra a quantidade de imigrantes que vieram ao Brasil após da abolição em 1888, onde o pais precisava crescer economicamente e então o governo republicano começou a incentivar a imigração europeia para "branquear" a nação já que eles acreditavam que a raça não-branca (raça inferior) estaria atrasando o crescimento do país, acabaram proibindo também a entrada de não brancos

Porém, sabemos que esse branqueamento não conseguiu acabar com a população de ex-escravos no Brasil, essa medida acabou aumentando a miscigenação um território brasileiro que hoje em dia é uma das populações com mais misturas de etnias e descendências do mundo.

1 - No gráfico podemos visualizar que houve uma entrada da imigrantes no Brasil e através de uma política de embranquecimento ficou claro que já havia no Brasil um racismo justificando que o Brasil poderia melhorar através da proibição da entrada de negros e pardos no país.

2 - Na minha opinião o governo que formulou a lei do embranquecimento muito não conseguiu resolver os problemas econômicos e políticos pois era incapaz de solucionar a maioria dos problemas do nosso país.

3 - No gráfico pode-se notar que em 1930 muitos imigrantes vieram para o Brasil e foi estipulado que o embranquecimento melhoraria as condições do nosso país, o Brasil.

4 - A imigração no Brasil que ocorreu na década de 1930 e teve a "Europa" como maior continente que veio para o Brasil ocorreu por causa de guerras e também pela política de embranquecimento feito pelo Brasil.

Houve (um) racismo na forma de criar a lei pois proibia a entrada de negros e pardos no país.

5 - A política de embranquecimento no Brasil ao invés de embranquecer a população brasileira acabou aumentando a miscigenação pois a população negra e branca que aqui já estavam e as populações que vieram não podiam ser proibidas de viver, construir famílias e laços de amizade.

\section{Vitória Pereira de Jesus}

O estado brasileiro no ano de 1888 a 1889, teve a ideia chamada, branquear o Brasil.

É realmente uma tolice! Uma pessoa só porque tem raça diferente e pele mais clara não tem o poder de afundar uma nação, ou causar dano por ser quem é.

Eles, não conseguiram ajudar de modo político, fazer melhorias, então apelaram para uma desculpa dessas, para enganar o povo, e justificar a incapacidade deles.

\section{Beatriz Souza}

Imigrantes no Brasil

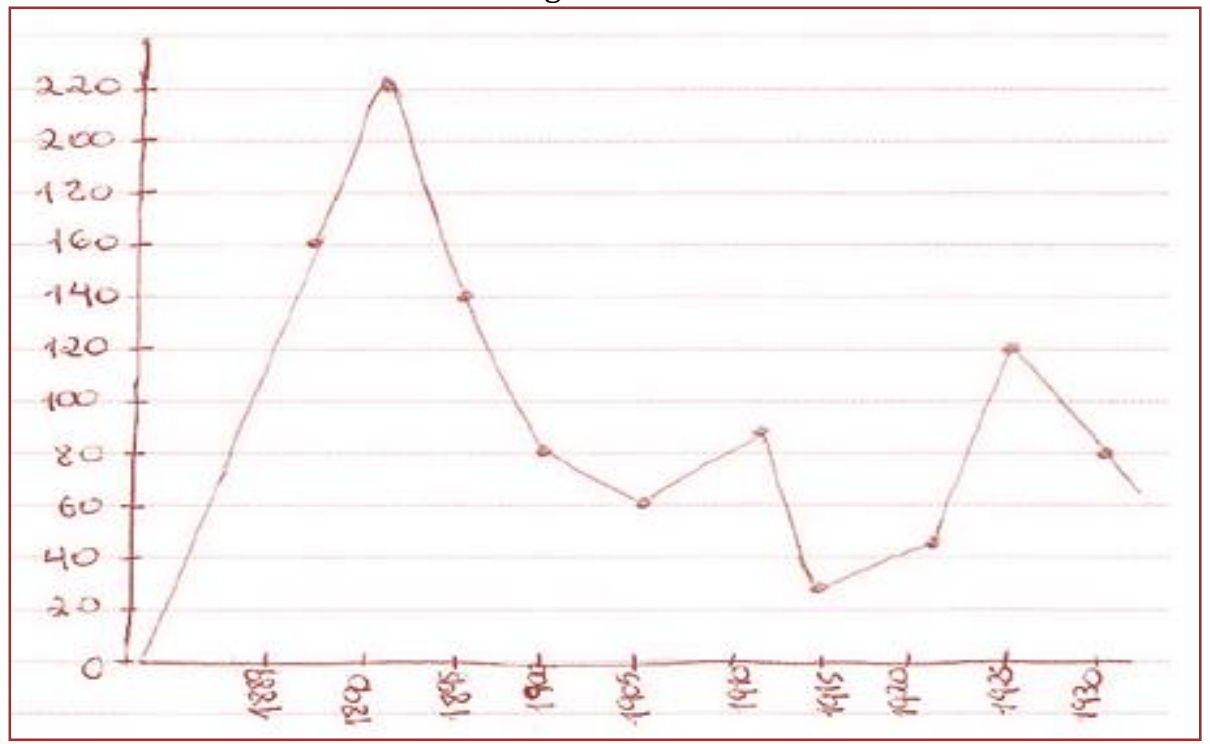


Como podemos observar no gráfico "imigrantes no Brasil”, a imigração do ano de 1889 e 1925 é realmente muito alta, a rede do império Português, pelo fato da abertura dos portos, as más condições na Europa. A partir de 1920 o número vai diminuindo, por conta das ditaduras, crises, industrializações, etc.

Sabrina Hellen do C de Souza

Gráfico imigrantes entrando no Brasil (1889-1930)

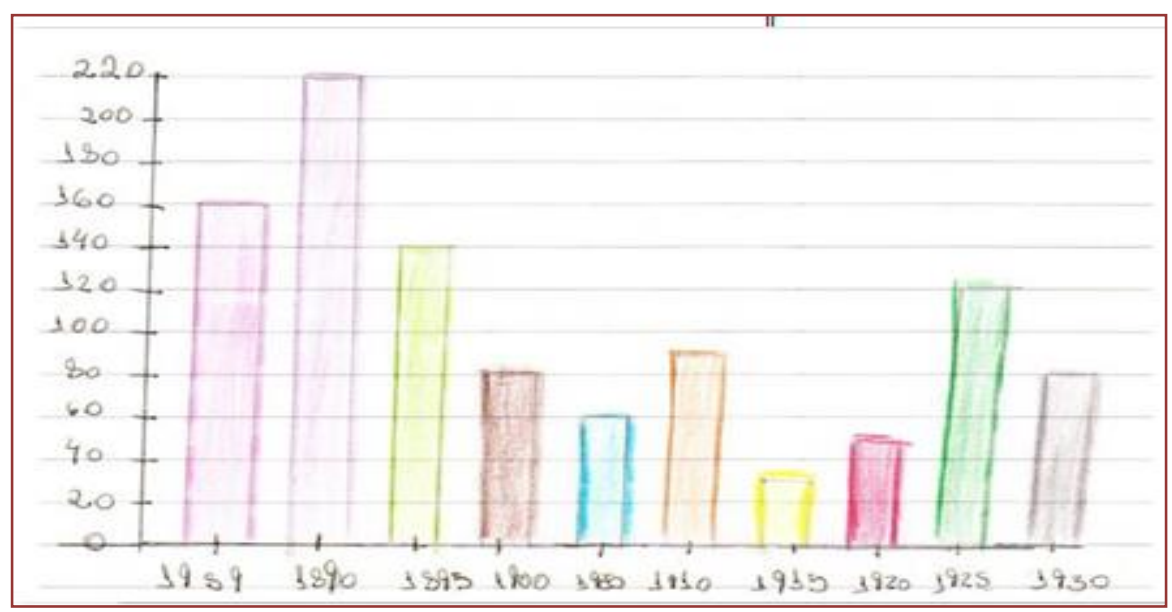

No gráfico a imigração é muito alta em 1889 e 1890, pela sede do Império Português e abertura dos portos. A partir de 1900 exceto 1925 o número diminuiu bastante por conta das ditaduras, industrializações e outros fatores.

\section{Jean Jovencio Bezerra}

Resumidamente, o texto relata sobre como o governo não aceitava pessoas não brancas. 0 Brasil entre outros países do continente americano, foi o último a acabar com o trabalho escravo, o que desencadeou consequências danosas para a formação de nossa nação. Isso aconteceu porque não foi colocado em prática um programa de estado que planejasse para a população negra uma adequada transição da condição de cativos para a de sujeitos livres. Sendo assim, minha crítica sobre o texto é dizer que não aceito essas indiferenças como por exemplo citado no final do texto da apostila, "o governo republicano passou a subsidiar e incentivar a imigração europeia para branquear a nação e proibiu a mesma entrada de não branco no país" e isso acaba gerando o racismo onde já mais deve ser citado e que jamais devemos praticar. 0 aumento da população branca, negra e parda no decorrer do ano de 1889 a 1930.

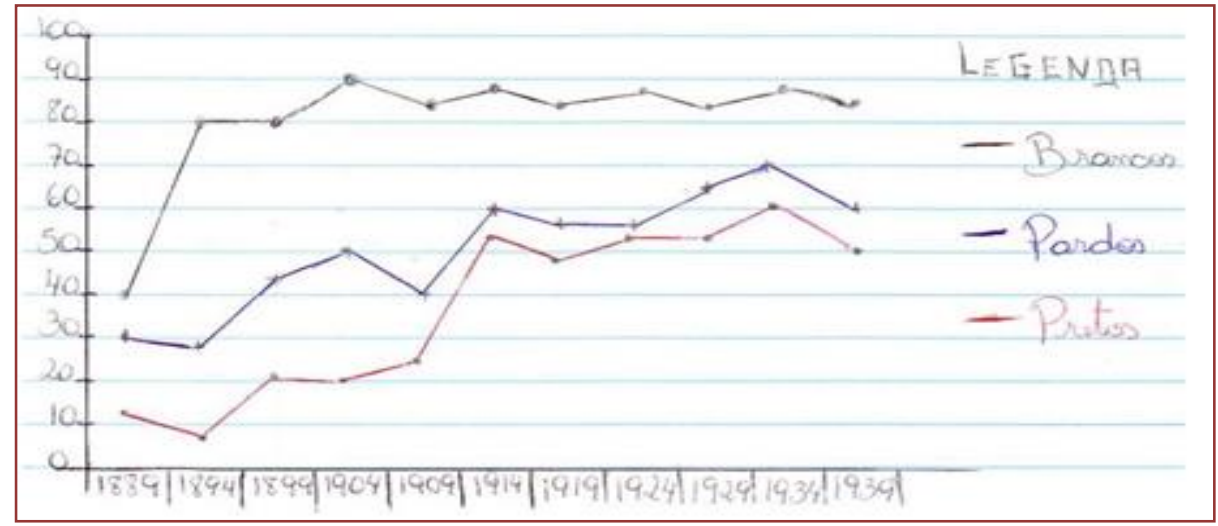


Pode se perceber que as temáticas africanas foram bem aceitas em sala de aula e que tanto as "memória quanto as narrações, brincadeiras e infância" são metodologias muito apropriadas para as turmas do ensino médio. Turma do 3o A.

\section{Luiza}

1 - Como foi sua infância?

1 - Minha infância vamos se dizer que eu me diverti muito, estudava de manhã e já brincava na escola de "pega ladrão", de balanço nas árvores. Adorava ir para educação física para brincar de pega bandeira.

Quando chegava em casa só comia e trocava de roupa e já ia brincar na rua com meus colegas. Ficava o dia inteiro na rua, muitas brincadeiras rolava, como taco, esconde esconde, pé na lata, etc. na época de pipa amava brincar com meus irmãos em cima da laje.

Quando era umas 21:00hrs da noite mãe gritava Rafael, Daniel, Juninho e Iza "está na hora, entra ou vou buscar". Assim íamos para casa tomar banho, jantar e sentar na frente da TV até cairmos no sono. No dia seguinte era a mesma rotina.

\section{2 - Que tipo de brincadeira mais gostava?}

2 - Eu gostava muito de juntar com minhas primas e o meu irmão Daniel de brincar de montar casinha na caixa de papelão era muito bonita nossas artes, inventava de tudo na casinha até os bonequinhos a gente fazia e simulava a luz acabando.

\section{3 - Quais amigos participavam?}

3 - Os meninos e meninas da rua de cima, de baixo do lado, se reunia para brincar. As vezes os vizinhos da rua de cima sempre arrumava briga mais no outro dia estava todo mundo lá na rua para brincar novamente.

\section{Lucas Alan}

As lembranças que tenho quando pequeno são poucas, mas minha mãe sempre me auxilia, com a sua memória porque ela é mais adulta e sempre me via brincar. Eu tinha um canto da casa onde eu brincava. Estudava em uma escola chamada Vitória Régia e meus amigos brincavam comigo de pega-pega e esconde-esconde no intervalo.

Fui criado por minha mãe e meu padrasto e tenho um irmão mais novo. Meus avós moram e tios moram próximos da minha casa e convivemos e compartilhamos muitas coisas. Um dos fatos mais marcantes da minha infância foi ter aprendido andar de bicicleta, ir à praia e ir ao estádio de futebol.

Os meus melhores amigos foram Gabriel, Carlos e Plablo.

\section{Maria Eduarda}

Na minha infância eu convivia com os meus avós materno, meu pai, minha mãe e meus dois irmãos. Sempre convivi com a minha família toda porem meus maiores laços de amor foram criados pela minha avó (Sandra), e meus avô (Edson), afinal foram eles que sempre me criaram e me deram amor em boa parte da minha infância.

Com certeza um dos fatos mais marcantes que eu tenho na memória é de quando eu meus avós irmos para a colônia de férias na praia, muitas das vezes a minha tia ia também. Era um lugar lindo, que tinha um parque incrível todo decorado com pinturas de princesas da Disney; eu amava as comidinhas que tinha lá e sem dúvida o momento mais feliz das férias era toda vez que ondas grandes vinham ele me levantava no colo, nesse momento eu ficava tão feliz que eu tinha a impressão que poderia voar. Outro fato marcante foi quando ganhei da minha tia (Fátima) uma boneca maior do que eu, que tinha os cabelos e as roupas completamente rosa, foi o presente que eu mais amei e essa boneca (que por sinal tinha até nome se chamava Estephane) foi minha "melhor amiga" durante muito tempo.

Eu tinha muitos amigos que até hoje chamo de IRMÃOS pois estudaram todo o meu período fundamental comigo (do primeiro ao quinto ano), mas nesse círculo de eu passava a maior parte do tempo com as minhas amigas Vitória, Geovana e Nathália. 
Eu adorava brincar com as minhas amigas de "fadas" pulando de mesa em mesa no parque da escola, e gostava muito de brincar fantasiando (também com elas) um fantasma que vivia atrás da quadra. Teve um passeio no 5o (quinto) ano para o Zoológico de São Paulo que foi incrível e foram todos os meus amigos, me diverti muito e foi o melhor passeio escolar que tive.

Eu estudei do $1^{\circ}$ ao 5ํa ano na escola Ana Manoela Barbos de Carvalho e estudo desde o 6o ano na escola Reynaldo Falleiros.

\section{Luemara}

A minha infância foi simples: o meu pai não conheci mas tenho curiosidade mas minha mãe nunca quis falar do assunto. Já passei dificuldade na infância mas nunca desisti de sonhar quando morava no Jardim Fátima (era comunidade) a rua era de terra e tínhamos que trocar de calçado ou colocar na sacola plástica no sapato para não sujar de lama. Eu vinha do Embu estudar no Pirajuçara (você não sabe professora é bem longe uns 40 minutos a pé). Minha mãe e minha tia eram próximas e ela já faleceu porem sei que ela está descansando (a alma) e sinto saudades.

Tive bastante amigos mas não vou citar (tenho vergonha) mas acho bom participar desse estudo (ensino em roda) para ser menos tímida.

Quando pequena brincava de roda, amarelinha e ia num parque bem próximo de casa. Hoje moramos numa casa confortável e ainda tenho muitos sonhos.

\section{Kauany Cristina}

São poucas brincadeiras que eu lembro, mas teve umas que marcaram de um jeito ou de outro. Rouba bandeira era uma brincadeira de rua, que eu brincava com meus vizinhos. A brincadeira era simples cada um ficava de um lado da rua e pegava um objeto cada um e nisso 5 participantes ou até mais tinha que despistar o adversário e tentar pegar a bandeira assim somava pontos e pontos.

Pé na lata era uma brincadeira em que pessoas enchia uma garrafa de areia, era parecido com escondeesconde, a pessoa procurava as crianças escondidas e quando achava saia correndo para chutar a garrafa e voltar de costas.

Pega-pega era outra, uma pessoa para pegar as pessoas que estão se divide.

Vivo duro - são mais de 10 pessoas, uma começa correndo atrás dos adversários e quando pega alguém é só falar "duro' e a pessoa fica parada para alguém vim e falar "mole” aí a pessoa voltava a brincadeira.

Esconde-esconde, todo mundo se esconde e todos vão se esconder e assim vai.

\section{Isabella Cardoso}

As brincadeiras são com certeza o que mais marcam a infância.

Me lembro que brincava muito de ciranda cirandinha e esta brincadeira marcou muitas gerações pois minha mãe também brincava. Brincar é uma das coisas mais gostosas da vida e é um símbolo de pureza de criança. Com o passar dos anos vamos sentindo saudade, ao rever as fotos e os vídeos antigos. Ao crescermos às vezes sentimos um pouco de amargura pois muitas vezes somos excluídos de dentro da sociedade, principalmente por causa de fatores econômicos. A pobreza é um dos principais fatores pelo quais as crianças deixam de ter oportunidades e por não termos condições desde bem pequenos nossa infância não é tão feliz. A brincadeira deveria ser um direito de todas as crianças.

\section{CONCLUSÃO}

Foi muito interessante a abordagem feita por alunos que narraram brincadeiras de infância e também o gráfico foi um recurso muito pertinente ao Período de Abolição e ao Período de História Atual. A análise dos gráficos fez com que cada aluno pudesse ter contato com a ideia de preconceito que assolou o Brasil nos anos trinta e ainda permanece. 0 trabalho teve um desfecho muito gratificante e como pesquisadora pude mudar a realidade dentro e fora da escola para melhor. 


\section{REFERÊNCIA}

[1] Munanga, Kabengele. Superando o Racismo na escola. 2a edição revisada. Disponível em: . Acesso em: 17 mar. 2018. LE GOFF, Jacques. História \& Memória - 7ª edição revisada. Editora Unicamp. Campinas - SP, 2013. P. 104. 


\section{Capítulo 11}

\section{Alunos e professores como atores centrais: Discussões $e$ dimensões das relações no processo de ensino $e$ aprendizado}

Simone Evangelista Fonseca

Cristiana Lara Cunha

Anderson Rocha de Jesus Fernandes

Sabrina Espinele da Silva

Antônio Artur de Souza

Resumo: 0 estudo em questão apresenta algumas discussões acerca das perspectivas teóricas sobre ensino e aprendizado bem como da prática de ambos. 0 trabalho ressalta ainda o papel e importância dos alunos e professores como atores centrais para os quais as diversas atividades desenvolvidas se voltam. 0 objetivo consiste em apresentar a temática problematizando a postura de ambos para concretização das propostas, além de apresentar ainda algumas dimensões externas que envolvem alunos e professores que podem influenciá-los enquanto atores centrais do processo de ensino e aprendizado. Conclui-se que a atuação conjunta de alunos e professores consiste em determinante fundamental do sucesso de processos de ensino e aprendizado. Sendo ainda que a prática mais libertadora nos sistemas de trocas de conhecimento contribui para uma emancipação social dos indivíduos. Embora tal prática não signifique um rompimento completo com sistemas educacionais tradicionais.

Palavras-chave: Ensino. Aprendizado. Alunos. Professores.

Artigo publicado na Revista Brazilian Journal of Development, Curitiba, v. 5, n. 2, p. 1361-1372, February, 2019 e também no III Congresso de Inovação e Metodologias no ensino superior: I Encontro de Licenciaturas, 2017. 


\section{ENSINO E APRENDIZADO: O CONTEXTO SOCIAL E A RELAÇÃO ALUNOS E PROFESSORES.}

A relação entre ensino e aprendizado consiste em aspectos relevantes e até mesmo polêmicos quando se trata da perspectiva acerca da educação na sociedade. As questões envolvidas refletem problemas que não representam meramente temas ou objetos de campanhas políticas em função da abrangência que possui em termos de pessoas atingidas. Dessa maneira a discussão ensino e aprendizado representa tema recorrente e de importância em discussões sociais, sejam acadêmicas ou mesmo políticas.

O presente ensaio tem como objetivo central apresentar a relação ensino e aprendizado abordando os impactos sociais que ela pode causar. 0 estudo apresenta algumas perspectivas e discussões de autores envolvidos no assunto, reforçando as perspectivas presentes no campo, entretanto, problematizando o papel de alunos e professores com relação às atividades propostas. 0 objetivo consiste em refletir as possibilidades, sobretudo, consequências de maior autonomia das partes perante ensino e aprendizado.

Pretende-se apresentar por meio deste uma reflexão da temática de ensino e aprendizado, bem como atribuir-se peso maior sobre os papeis dos alunos e professores na questão, desempenho em atividades e envolvimento enquanto atores ou agentes principais para os quais atividades são propostas. Esse desempenho envolve ainda dimensões que extrapolam o ambiente de ensino e aprendizado, como cansaços extensivos oriundos da rotina, problema familiar ou mesmo desinteresse aos conteúdos programados para determinadas disciplinas que não podem deixar de serem citados.

Contudo, o presente ensaio encontra-se estruturado nessa primeira seção de considerações iniciais com apresentação das ideias centrais. Uma segunda seção conta com a apresentação das principais vertentes teóricas que sustentam o desenvolvimento do estudo. Uma terceira seção na qual se coloca a problematização identificada entre atores centrais no processo ensino e aprendizado. Sendo apresentada por último uma seção de fechamento do trabalho na qual constam as considerações finais acerca da discussão desenvolvida no presente trabalho.

\section{OS PROCESSOS DE ENSINO E APRENDIZAGEM: VERTENTES TEÓRICAS, DIMENSÕES E PERSPECTIVAS}

Uma mentalidade mecanizada do processo de ensino e aprendizado, segundo Giusta (2013) consiste em uma consideração isolada desses termos e dos seus conceitos formais. A autora destaca que ambos não possuem uma relação tão natural, desperta a atenção para o fato de que o processo de ensino não assegura o de aprendizado e não existe uma relação harmônica muito natural, entre eles, natural no sentido de exata/garantida.

Historicamente, havia uma negação do sujeito dada a objetividade requerida pelo método cientifico que vem sendo derrubada, por exemplo, com experimentos comportamentais. Surge um fator fundamental nas relações de troca do conhecimento, a reciprocidade a ser incluída no planejamento do ensino (Giusta, 2013). A perspectiva aponta que não basta professores ensinarem sem alunos interessados em aprender.

Segundo Piaget (1976), a concepção do conhecimento ocorre de forma construtivista no processo de ensino e aprendizado. A vertente aborda uma perspectiva de amplitude conceitual envolvida numa questão entre equilíbrio interno com um conflito cognitivo capaz de dar novo significado ao próprio papel do professor.

Piaget (1976) também evidencia o caráter mediador do professor, agente competente em conteúdo, cognição, epistemologia e socioafetividade no processo de ensino e aprendizagem. Essa perspectiva reflete ainda a uma observação da extensão do processo, ampliação de meios e sistemas de trocas efetivas entre indivíduos, sistemas esses autônomos e complexos quanto às trocas bem como participativos.

Na reflexão do papel do professor, torna-se válido ressaltar algumas dimensões da prática destacadas em Alcadipani (2005) quanto à rotina do profissional. 0 autor chama atenção para os desafios da categoria em termos de rotina e cotidiano repetitivos que podem levar ao desgaste excessivo ou mesmo comprometer um sonho de conhecimento, vontade de aprendizado e ensino. 0 autor evidencia sério questionamento quanto à formação do professor pesquisador que em início de carreira vivencia sensações como inexperiência, medo, aflição e insegurança (Alcadipani, 2005). Sendo que em contrapartida vencido esse início de carreira existe uma tendência forte ao pragmatismo quanto às atividades, professores podem tender a ser "reprodutivismo" de conteúdos prontos. 
As sensações vivenciadas pelos professores podem ser relacionadas também com o abordado por Nicolini (2003) quanto ao tratamento dado ao conhecimento no processo de ensino e aprendizagem de bacharéis em administração. 0 estudo apresenta uma importante discussão do ensino de Administração no Brasil diante do aumento de complexidade e demanda do mercado. Um aumento que contribui para o pragmatismo no ensino.

Nesse ponto destaca-se o surgimento de diversos cursos de especialização em negócios que estagnam o campo de estudo, sobretudo, limita a atuação do professor. No sentido em que os alunos se tornam produtos (Nicolini, 2003) e junto dos próprios professores ambos acabam deixando a posição de sujeitos (Piaget, 1976) no processo de ensino e aprendizado que no caso da massificação acaba gerando uma industrialização de um conhecimento estagnado em função do contexto. No caso o conhecimento acaba sendo tratado como instrumento para respostas rápidas ao contexto.

A industrialização do conhecimento ou a padronização excessiva dos métodos compõe parte do que Cunha et al (2006) chamam de desafios de legitimidade do ensino superior diante dos interesses da iniciativa privada. Os autores abordam que quando passam de alunos para professores, há uma descoberta de que o saber é algo insuficiente por natureza e o aprendizado consiste em um processo contínuo que depende bastante da experiência. Sendo necessária a disposição dos professores para que também perceba no contexto de salas de aulas o que acontece com os alunos.

Para Freire (1996) o professor tem papel fundamental no processo de ensino e aprendizado, além da missão, o professor tem ainda compromisso de dar devidas condições aos alunos para que se tornem seres sociais pensantes, transformadores e criadores de soluções diante de problemas sociais existentes no meio que vivem. Para tal, o autor defende o uso da liberdade que deve ser concedida ao aluno de forma correta.

Assim, Freire (1996) acredita em um ciclo de desenvolvimento dos alunos que passa da autonomia à capacidade crítica, desta à valorização cultural e retoma a autonomia em um ensino progressista que engloba processo social, de formação e de transformação de saberes construídos gradativamente.

Batista et al (2015) abordam a importância de também se ensinar aos jovens o desenvolvimento de suas habilidades para crescimento individual. Os autores apresentam um estudo de caso a cerca da criatividade numa instituição de ensino superior e evidenciam os impactos e influências do ambiente sobre a mesma. 0 estudo ressalva que a criatividade consiste em uma característica ou atividade bastante saudável para o indivíduo. Em pesquisa numa instituição da Amazônia, os autores demonstram ainda que as principais vantagens percebidas para os cursos pesquisados são interesse em aprendizagem e incentivos a ideias. Em contrapartida, os professores constataram déficits entre os processos de ensino e avaliação, falta de coerência entre propostas (Batista et al, 2015).

A questão da avaliação como método de julgamento do conhecimento abstraído de alunos consiste numa problemática abordada em Perrenoud (1999). A perspectiva apresentada destaca que por mais que escolas e sistemas educacionais passem por diversas mudanças a metodologia permanece, sobretudo, pode desmerecer ou enaltecer alunos bem como provocar uma hierarquização entre eles. Segundo o autor, em contrapartida, a avaliação também funciona como forma de se reforçar para o aluno a necessidade de saber.

Na verdade a avaliação não seria um fim do processo de ensino e aprendizado, ela consiste em uma orientação e em formas de controle e gestão que os professores têm para conduzir o fluxo de trabalho (Perrenoud, 1999).

O processo avaliativo acaba por consistir no retorno ou feedback que os alunos acreditam ter sobre seus níveis de aprendizagem, dessa forma acaba-se formando um sistema educacional embasado na classificação desses alunos sobre critério de notas (Nascimento, 2011). Por meio do instrumento, se realizam inferências acerca dos níveis educacionais, como no caso do Exame Nacional de Desempenho do Estudante (Enade), realizado como forma de análise do ensino superior no país.

Para Canen e Oliveira (2005), o processo de avaliação de níveis educacionais e de desenvolvimento do país, passa ainda por dimensões que as autoras definem como multiculturais e que vão além de generalizações. A dimensão educacional nessa perspectiva avaliativa envolve identidades que trazem diferenças e geram até mesmo preconceitos entre os grupos sociais formados. 
O estudo cita como exemplo a cultura indígena e sobrevivência da sua identidade diante demais, bem como os preconceitos sofridos. 0 estudo ressalva também que esse multiculturalismo exerce influências sobre ensino e pesquisa como fator determinante das práticas adotadas na educação (Canen e Oliveira, 2005).

A discussão das práticas de ensino em universidades superiores também retoma o estudo de Valente e Viana (2009) quanto às competências do docente nas instituições de ensino. Aborda a temática de formação para a carreira docente e se relaciona com a proposta de Perrenoud (1999) no que tange à formação e às competências dos professores. Competências como aptidão para conduzir o processo de ensino e aprendizado não necessariamente simultâneo. Capacidade de proporcionar progresso e evolução aos alunos, envolvê-los e mostrá-los como superar conflitos e administrar-se profissionalmente (Valente e Viana, 2009).

De acordo com Veiga Simão e Frison (2013) a prática de ensino e o contexto educacional envolvem também desafios profissionais e pessoais do docente, desafios presentes no contexto em que este se encontra. Existe nesse caso uma série de desafios quanto a prática do ensino e aprendizado que vão desde a sua formação, metas e atuação de fato, questiona-se quão preparados estão (Veiga Simão e Frison, 2013).

O estudo de Pranke e Avila (2015) denota também a dificuldade de ensino de estagiários docentes do curso de licenciatura em matemática. Os jovens docentes apresentaram no relatório final da atividade preocupação em manter as atividades com alunos de forma coesa, percebendo que a aprendizagem não se resume a uma lista de procedimento a ser executada, não se resume a uma aprendizagem autorregulatória. Nesse sentido, o estudo reflete a capacidade do docente em perceber a absorção de conteúdo por alunos.

Pranke e Avila (2015) retomam também o abordado por Frison (2016) que discorre sobre a formação docente em diferentes contextos com percepção de que o investimento na autoformação do professor tem ganhado significativa importância. Uma vez que a atuação do professor, de acordo com o autor, também engloba sua carreira profissional cuja formação não termina com fim da licenciatura.

O papel no processo de ensino e aprendizado coloca o professor responsável por desenvolvimento de aptidões tanto de alunos quanto de si próprio. Assim como abordado em Einstein et al (1935) no questionamento da física não se tratar de uma ciência completa. Nota-se diante das diversas vertentes que os processos de ensino e aprendizagem também não o são, nem mesmo tornam as partes envolvidas, tanto discentes quanto docentes, seres completos, se tratam de processos contínuos e mutáveis em diversificados períodos de tempo bem como contextos que permitem desenvolvimento dos envolvidos.

\section{PROBLEMÁTICAS E DESAFIOS NO ENSINO E APRENDIZADO}

Ensino e aprendizado não apresentam processos ou etapas naturais de transmissão de conhecimento. Um dos desafios dados aos professores consiste na reciprocidade abordada, por exemplo, em Giusta (2003). Nessa perspectiva fica o questionamento acerca de como professores podem tornar a relação mais recíproca e como alunos podem ser envolvidos.

A opção de autonomia dada ao aluno, abordada em Freire (1996) poderia favorecer a reciprocidade, entretanto, alunos além de cientes do benefício precisam apresentar maturidade. Por outro lado a proximidade entre aluno e professor dados os papeis de cada um diante do conhecimento também seria fator favorável, cabendo ainda o diálogo entre cada parte e o espaço para que ambos se ouçam também, sem hierarquização ou mesmo opressão dado a posição do ator no processo.

A transmissão do conhecimento representa fator importante nos processo de ensino e aprendizado. Na perspectiva como de Piaget (1976) o conhecimento ainda se faz um conhecimento construtivo. As relações alunos e professores no ensino e aprendizado também ocorrem em um processo de trocas, as perspectivas dos alunos sobre determinado conhecimento também permite que o professor aprimore sua explicação. Muitas vezes professores podem se acomodar em conteúdos e acreditar que estejam sendo o mais claro possível na transmissão ou como facilitador do conhecimento ao aluno, esquecendo-se de tentar perceber se de fato está sendo compreendido. 
Inegavelmente alunos aprendem com professores e professores dispostos também aprendem com seus alunos. 0 estágio docente seria um exemplo claro disso, com o contato inicial de um futuro docente com as práticas educacionais, permite a ele executar atividades de ensino e aprendizado, bem como pode o influenciar ao dar abertura para alunos contribuírem com a percepção que tenham tido sobre assuntos. Se o estagiário permite espaço ao aluno para que lhe de retornos, sinais ou indícios de compreensão ou não de conteúdos, consegue perceber diante de sua turma como tem conduzido o processo de ensino e aprendizado, assim pode até mesmo se aprimorar, caso seja necessário.

Entretanto, o ensino e aprendizado em uma via de mão dupla talvez não seja algo muito comum se observarmos pela dimensão de profissionalização aborda por Nicolini (2003). Com a profissionalização há uma massificação do conhecimento em que a lógica capitalista demanda quantidades e quantidades de alunos sendo formados. Uma formação acadêmica orientada ao capitalismo e assim, resultante de uma mercantilização do próprio conhecimento.

A quantificação não permite que as trocas no processo de ensino e aprendizado ocorram com maior frequência ou mesmo ocorram. Na verdade, com a profissionalização os alunos passam pelos cursos, muitas vezes buscam apenas títulos que, por outro lado, estejam sendo vendido por determinada instituição. Atualmente as trocas mediante a profissionalização não ocorrem necessariamente assegurando ensino e aprendizado ou mesmo a produção de conhecimento de forma construtiva e contínua de Piaget (1976).

0 conhecimento de forma gradativa segundo a própria perspectiva de Freire (1996) condena a rigidez nos processos de ensino e aprendizado, liberdade e responsabilidades dadas ao aluno permitem maior envolvimento dos agentes. Deixar livre de uma forma consciente pode favorecer o processo gradativo de construção do conhecimento. Entretanto, essa autonomia dada aos alunos não implica em total efetividade do ensino e aprendizado, mas reforça a consciência do beneficio em se buscar conhecimento.

Quando a busca e a vontade de se conhecer atingem o aluno de forma consciente, o fator criatividade abordado em Valente e Viana (2010) se fortalece. Alunos tendem a maior envolvimento com propostas que em contrapartida devem ser elaboradas pelos professores de forma desafiadora. Cabe ao professor a percepção de quão dispostos a se envolver nos processo de ensino e aprendizado estão seus alunos. Nesse ponto não existe uma parte envolvida que seja mais responsável do que a outra, o que também se reforça no caráter recíproco, gradativo e contínuo dos processos de trocas de conhecimento.

Se as partes envolvidas no processo de ensino e aprendizado encontram-se maduras para a autonomia e as trocas de conhecimento dos processos, isso pode favorecer ainda a mudança das avaliações ressalvada em Perrenoud (1999) para que haja uma mudança pedagógica, entretanto a maturidade não se assegura nos processos de ensino e aprendizado, não existe forma de controle para tal ou mesmo para garantir que ela venha, o que pode dificultar o processo.

Professores ainda não possuem outra forma de avaliação e controle na medida em que alunos se habituaram ao mecanismo. Há uma alternativa quando o processo avaliativo passa, os agentes podem conversar após o ocorrido para futuras mudanças, mas nada assegura que os pontos de vistas não estejam enviesados em função do próprio costume.

Dessa forma os processos de ensino e aprendizado representam etapas fundamentais de transmissão e absorção de conhecimento entre os principais agentes envolvidos, alunos e professores. Atividades que segundo Pranke e Avila (2015) e Frison (2016) favorecem desenvolvimento das pessoas e a construção de saberes. Para Silva e Brasileiro (2017) a pluralidade de saberes e a democratização do conhecimento torna-se fundamental no processo de ensino, sobretudo o universitário, que por vezes tem foco em promover a formação para o mercado.

Silva e Brasileiro (2017) ressalta também que esses processos não se tratam de um abandono total de métodos tradicionais e sistêmicos de ensino e aprendizado. Mas consistem em práticas mais dialogadas, libertadoras e emancipatórias aos indivíduos com relação ao contexto social em que estão inseridos.

Em contrapartida, há contextos que podem favorecer ou dificultar as trocas de conhecimento, experiências e pontos de vistas dos envolvidos. Não há uma visão romântica do processo de ensino e aprendizado uma vez que as suas dimensões envolvidas apresentam certas complexidades que fogem do controle tanto de alunos e professores. Mas pode ocorrer uma harmonia entre as partes diante à dinâmica de trocas, para que as atividades se cumpram e ambos aproveitem ao máximo o que a situação pode proporcionar em termos de ensino e aprendizado nas trocas contínuas de conhecimento. 


\section{CONSIDERAÇõES FINAIS ACERCA DA DINÂMICA DE ENSINO E APRENDIZADO NA ATUAÇÃO DE ALUNOS E PROFESSORES}

0 processo de ensino e aprendizado consiste em formas contínuas de trocas de conhecimento entre agentes envolvidos, as atividades se voltam principalmente para as relações diretas existentes entre alunos e professores. A transparência aparenta ser o aspecto principal para a construção de relações sólidas entre as partes, entretanto, a maturidade representa outro aspecto determinante desse relacionamento. A efetividade no ensino e aprendizado não pode ser assegurada por nenhuma das dimensões dos processos, mas as partes dedicadas podem favorecer os resultados.

Os processos de ensino e aprendizado envolvem forte dependência dos esforços entre partes envolvidas. Tais processos representam etapas de trocas de conhecimento que não ocorrem de forma natural e automática. Os esforços bem como relação dos atores ocorrem de forma bilateral. De nada adiantam esforços e participação ativa apenas de uma das partes envolvida para que haja desafios e inovações de ensino e aprendizado, se alguma dessas partes principais das relações não tiver de fato interesse e envolvimento nas trocas.

Na verdade fica ainda um pequeno questionamento quando se fala em processos de ensino e aprendizado e na troca de conhecimento para desenvolvimento intelectual de indivíduos. Não se sabe ao certo o quanto a alerta às partes envolvidas pode ou não contribuir para o relacionamento recíproco, motivado e contínuo dos atores envolvidos. Caso essas alertas sejam válidas, surgem questões ainda de como elas podem ser recebidas pelas pessoas, podendo causar comportamentos adversos em termos de responsabilização e autonomia de cada indivíduo, bem como desconfortos.

Os processos de ensino e aprendizado permitem trocas de conhecimento de forma bilateral entre alunos e professores. Para que essas trocas sejam contínuas, ambos os envolvidos precisam estar de fato dedicados a seu papel e para o que ocorre e lhes é proporcionado em termos de conhecimento, aprendizado e experiências em um determinado contexto gerem bons resultados.

Como apontado em Silva e Brasileiro (2017) diversas instituições de ensino como as universitárias têm como objetivo central a capacitação para o mercado. Entretanto uma pluralidade de saberes e a própria democratização educacional fortalecem uma emancipação dos indivíduos no contexto social. 0 que não implica em abandono de metodologias de ensino convencionais, mas atenta para a importância do diálogo.

Sendo que esse contexto pode ser ainda o determinante de formas mais aconselháveis de como os processos de ensino e aprendizado podem ser conduzidos para que resultem em um conhecimento construtivo e contínuo das pessoas com passar do tempo. Formas que poderão ser aprimoradas de acordo com as motivações, sobretudo, o envolvimento de indivíduos, mesmo que a prática envolva uma grande complexidade de problemas, assim como desafios. Uma vez que o desempenho envolve dimensões que perpassam o contexto momentâneo das atividades de ensino ao duradouro de aprendizado.

\section{AGRADECIMENTOS}

O presente trabalho foi realizado com apoio da Coordenação de Aperfeiçoamento de Pessoal de Nível Superior Brasil (Capes) Código de Financiamento 001.

\section{REFERÊNCIAS}

[1] Alcadipani, Rafael. A hiperatividade do professor Bombril. Organizações \& Sociedade, v. 12, n. 35, p. 161-163, 2005.

[2] Batista, Eraldo Carlos; Luz, Edson Neves; Brum, André Luiz de Oliveira. Autopercepção sobre as práticas docentes para o desenvolvimento da criatividade em uma instituição de ensino superior da Amazônia. Revista Intersaberes, v. 10, n. 21, p. 595-612, 2015.

[3] Canen, Ana; Oliveira, Ângela MA de. Avaliando a avaliação a partir de uma perspectiva multicultural. Educação Brasileira, v. 27, n. 54, p. 95-114, 2005.

[4] Cunha, Ana Maria de Oliveira; Brito, Taita Talamira R.; Cicillini, Graça Aparecida. Dormi aluno (a)... Acordei professor (a): interfaces da formação para o exercício do ensino superior. Políticas de Educação Superior, n. 11, 2006.

[5] Einstein, Albert; Podolsky, Boris; Rosen, Nathan. Can quantum-mechanical description of physical reality be considered complete? Physical Review, v. 47, n. 10, p. 777, 1935. 
[6] Freire, Paulo. Pedagogia da autonomia: saberes necessários à prática educativa. São Paulo: Paz e Terra. 2006.

[7] Frison, Lourdes Maria Bragagnolo. Encontro com a docência: narrativas de autoformação que revelam aprendizagens autorreguatórias. Revista Interinstitucional Artes de Educar, v. 2, n. 2, p. 204-221, 2016.

[8] Giusta, Agnela da Silva. Concepções de aprendizagem e práticas pedagógicas. Educação em Revista, v. 29, n. 1, p. 20-36, 2013.

[9] Nascimento, Marlúcio Tavares do. Instrumentos de avaliação da educação superior: continuidades e avanços. Revista Eletrônica Faculdade Montes Belos, v. 4, n. 1, 2011.

[10] Nicolini, Alexandre. Qual será o futuro das fábricas de administradores? Revista de Administração de Empresas, v. 43, n. 2, p. 44-54, 2003.

[11] Perrenoud, Philippe. Avaliação: da excelência à regulação das aprendizagens-entre duas lógicas. Artmed, 1999.

[12] Pranke, Amanda; Avila, Luciana Toaldo Gentilini. Formação inicial de professores em matemática à distância: o portfólio como instrumento de reflexão nos estágios. Educação em Revista, v. 16, n. 2, 2015.

[13] Piaget, Jean. A equilibração das estruturas cognitivas: problema central do desenvolvimento. Rio de Janeiro: Zahar, 1976.

[14] Silva, João R. ; Brasileiro, Tania S. A. . Educação como prática da liberdade e a perspectiva da educação integral no ensino superior. Educação: Teoria e Prática, v. 27, p. 526-541, 2017.

[15] Valente, Geilsa Soraia Cavalcanti; Viana, Ligia de Oliveira. Da formação por competências à prática docente reflexiva. Revista Iberoamericana de Educación, v. 48, n. 4, p. 1, 2009.

[16] Valente, Geilsa Soraia Cavalcanti; Viana, Ligia de Oliveira. O ensino de nível superior no Brasil e as competências docentes: um olhar reflexivo sobre esta prática. Práxis Educacional. Vitória da Conquista, v. 6, n. 9, p. 209-226, jul./dez. 2010.

[17] Veiga Simão, Ana Margarida da; Frison, Lourdes Maria Bragagnolo. Autorregulação da aprendizagem: abordagens teóricas e desafios para as práticas em contextos educativos. Cadernos de Educação, n. 45, p. 02-20, 2013. 


\section{Capítulo 12}

\section{Experimentando processos de formação}

\section{Pollyana Aguiar Fonseca Santos}

\section{Kátia Maria Kasper}

Resumo: Este texto é um recorte de aspectos de uma dissertação de mestrado defendida em 2016, abordando processos de formação disparados por um projeto realizado em uma escola pública estadual de Curitiba. Tal projeto foi proposto pela equipe pedagógica e direção da escola e realizado no horário regular das aulas, nos períodos matutino e vespertino. As atividades do projeto consistiram em organizar grupos - abrangendo todos/as os/as estudantes e professores/as das doze turmas de 6ㅜ a 9o ano do Ensino Fundamental regular, existentes naquele ano - reunidos por afinidade com um dos temas propostos. A pesquisa, por sua vez, consistiu em cartografar alguns efeitos educacionais gerados, por meio da produção de depoimentos dos participantes. Buscando pensar nos processos de criação e formação, nas tensões e limites do desdobramento desse projeto na escola, o qual provocou reinvenções no currículo escolar, criando possibilidades de estabelecer conexões, de multiplicar os vetores de ação e interação. E ainda, contribuiu para mover o pensamento, para promover o envolvimento e o trabalho coletivo na escola, e uma aprendizagem por contágio.

Palavras-chave: Formação. Currículo. Cartografia. Aprender por contágio. 


\section{EXPERIÊNCIAS CURRICULARES E PROCESSOS DE FORMAÇÃO}

A pesquisa ora apresentada, realizada entre os anos de 2015 e 2016, teve como objetivo investigar processos experimentais de formação disparados por um projeto ocorrido em uma escola pública estadual de Curitiba. 0 projeto, desenvolvido durante o letivo de 2014, foi proposto pela equipe pedagógica e direção, e realizado no horário regular das aulas nos períodos da manhã e da tarde, abrangendo todos/as os/as estudantes e professores/as.

A realização do projeto, com tudo que a envolveu, provocou alterações na organização da escola, alterando o funcionamento dos horários, as relações entre professores/as e estudantes e os modos de ocupar os espaços.

Paralelamente a esse movimento do projeto na escola, foi sendo construído o projeto da pesquisa, voltado a possibilitar a problematização e ampliação das conexões e discussões sobre aquilo que estava sendo pensado e feito na educação escolar. A pesquisa provocou a pensar nos processos de criação e formação, nas tensões e limites no desenvolvimento do referido projeto na escola e nos seus desdobramentos.

Os caminhos da pesquisa foram traçados de modo a, também, investigar alguns efeitos do movimento gerado pela proposição e realização do projeto na escola, por meio da produção de depoimentos dos participantes. 0 universo de entrevistados foi definido pelos próprios participantes, conforme sua disponibilidade e interesse em participar naquelas circunstâncias. Desse modo, foram realizados quatorze depoimentos, dos quais cinco alunos, duas alunas, quatro professoras, uma funcionária, uma pedagoga e o diretor.

As conversações foram produzidas ao cartografar algumas das relações que se romperam ou se estabeleceram por conta do projeto; relações de força implicadas, possíveis acontecimentos e seus desdobramentos. A cartografia tem a potência de proliferar sentidos e inaugurar novos problemas, incluindo a própria constituição da pesquisadora, de um corpo aberto, atento e sensível; uma pesquisa que não pretende a totalidade, mas traça o diagrama de forças, linhas que compõem e atravessam um território, grupo social, indivíduo (DELEUZE; GUATTARI, 1995, 1996; DELEUZE; PARNET, 1998).

0 presente texto visa - ao apresentar algumas ações e possibilidades do projeto, mesmo sem pretender a sua totalidade - instigar a pensar em algumas das experiências curriculares e alguns dos processos de formação que puderam ser experimentados e (re)criados pelo/com o projeto realizado em uma escola estadual de Curitiba.

As atividades do projeto consistiram em incentivar e criar oportunidade para que os/as estudantes - das doze turmas de 6ㅇ a 9o ano do Ensino Fundamental regular existentes naquele ano - se organizassem em grupos por afinidade com um dos temas propostos pela equipe pedagógica e direção escolar. Tais grupos poderiam ser formados por membros da mesma turma, mas se reuniriam com grupos de outras turmas e turnos que tivessem interesse no mesmo tema. Os temas, então denominados "desafios", tinham como objetivo serem disparadores para desenvolvimento de pesquisas, projetos e ações protagonizados pelos/as estudantes, tais como promover debates, visitas técnicas, campanhas, palestras, oficinas, jogos, peças teatrais, intervenções etc. Dentre os desafios, podem ser citados: Esporte e Lazer; Direitos e Deveres (posteriormente Estatuto da Criança e do Adolescente); Drogas; Sexualidade; Tecnologia e Inovação; Cidadania e Meio Ambiente; Literatura, Filosofia, Ciência e Arte.

\section{INTERROMPER}

O que o projeto pôde suscitar, provocar, criar?

Ele possibilitou algumas suspensões, interrupções, alguns desvios. Suspender... a organização, os planos, a rotina. Interromper... as aulas, as expectativas, a previsibilidade. Como no dia em que, em meio à rotina da escola, vozes delicadas - ainda de criança, mas determinadas a divulgar artigos do Estatuto da Criança e do Adolescente e os respectivos comentários, por elas pensados e criados - foram captadas pelo microfone conectado ao sistema de som e ecoaram nas caixas por toda escola. Podiam ser ouvidas no pátio, no jardim, nos corredores, nas salas. Vozes, ainda que delicadas, tiveram a força de provocar o pensamento, desestabilizar certezas.

O projeto também provocou tensões nos modos de estar na escola e de pensar a educação e o currículo escolar, em meio às discussões envolvendo toda a comunidade escolar sobre como colocá-lo em prática. 
Em meio a essas tensões, o projeto desencadeou processos de criação e de formação em uma série de ações. Dentre elas, mencionamos a tarde em que os palhaços ocuparam a escola; o longo caminho em um ônibus articulado lotado de crianças rumo ao Circo da Cidade7; as visitas de diferentes grupos de estudantes à escola de educação especial vizinha ou à uma comunidade terapêutica ${ }^{8}$; a roda de conversa entre estudantes adolescentes e um casal de alunos do período noturno (EJA ${ }^{9}$ ); o já citado uso do sistema de som pelos/as estudantes para ser porta-voz de artigos do Estatuto da Criança e do Adolescente; e outras inúmeras atividades em espaços externos ou instituições culturais, esportivas, educativas etc.

0 projeto "A escola que queremos" realizou-se nos movimentos e mudanças dos modos de estar e ocupar os espaços na escola. No tempo intensivo, em que tudo acontece ou pode acontecer; no tempo da velocidade da vida, mesmo na escola.

Naquela tarde, tudo girava. Fluxos. Palhaços chegando. Os palhaços já chegam palhaços, não falam muito, trazem suas malas e outros cacarecos, que depois, durante o espetáculo, ganhariam vida. Trazem sua irreverência, estremecem o chão da escola e perturbam a tranquilidade mesmo daqueles que estão entre quatro paredes. Com o palco montado no pátio da escola, professores/as e funcionárias procuram organizar rigorosamente os/as estudantes para assistir ao espetáculo, sentados em bancos ou no chão. Os/as estudantes sentados/as no chão não sentem desconforto; desconfortável é a posição do/a professor/a em uma situação como aquela - fora do território da sala, sem a segurança de sua mesa de professor, do amparo do quadro e do giz. 0 corpo-professoral tenta sair do papel daquele que tudo controla. Deixa de controlar todos, o tempo todo, para também participar, vivenciar o momento, estar presente. Mas quando se dá conta de que está vivo e presente, sente um desconforto, uma tensão entre a abertura possível e aquilo que pensa ser necessário fazer; sente que deve voltar ao seu papel: controlar os/as estudantes, não permitir que se levantem, nem que gritem, nem que riam alto, nem... Melhor não permitir. Sabe-se lá onde isso vai dar!

O funcionamento dos grupos do projeto envolveu fluxos difíceis, ou mesmo impossíveis, de controlar, seguindo em múltiplas direções. Enquanto alguns buscavam materiais para confeccionar cartazes para divulgar artigos do Estatuto da Criança e do Adolescente, outros reuniam-se em torno de computadores para produzir uma animação utilizando um software livre, sob orientação de um professor convidado para ministrar um minicurso. Outro grupo, sentado sob as árvores, conversava animadamente, buscando pensar nas ações relacionadas ao meio ambiente que iriam realizar, e, pautados pelo slogan "pensar globalmente e agir localmente", recém ensinado pelo professor que participava do grupo, logo partiram para a ação, realizando um mutirão de limpeza na escola. Muitos outros haviam saído e seguiam a pé ou em ônibus escolares para destinos distantes ou próximos da escola, e eram recebidos para visitas, palestras e apresentações culturais. Onde tudo isso vai dar?

\subsection{RACHAR}

0 projeto provocou o pensamento, intervindo nos modos de pensar e realizar ações educativas na escola, colocando em jogo o que, como, quando e onde se ensina, quem ensina, questionando as relações. Possibilitou algumas reinvenções do currículo (escolar).

0 currículo envolve as dimensões espacial, temporal e das relações, “o currículo é lugar, espaço, território. 0 currículo é relação de poder." (SILVA, 2002, p. 150). As ações envolvendo o projeto se inseriram na ordem já estabelecida, rachando-a, desestabilizando-a. Desterritorializações. Invenções de outros espaçostempos, sem a pretensão de substituir, "embora se contraponham ao instituído, coexistem com ele" (GALLO, 2015, p. 85).

Ainda que as aulas expositivas, exercícios, provas seguissem. Importou a ênfase dada aos processos criação de espaços e tempos de ouvir, pensar, sentir - e ao modo como cada um estabelece conexões entre o que vive fora e dentro da escola. "Importa fazer rizoma. Viabilizar conexões e conexões; conexões sempre novas. Fazer rizoma com os alunos, viabilizar rizomas entre os alunos, fazer rizomas com projetos de outros professores. Manter os projetos abertos" (GALLO, 2002, p. 175).

\subsection{COMPOR}

\footnotetext{
7 Projeto financiado pela Fundação Cultural de Curitiba.

${ }^{8}$ Instituição voltada ao atendimento a dependentes químicos.

${ }^{9}$ A escola ofertava educação de jovens e adultos no período noturno.
} 
No início da tarde, os/as estudantes chegam animados e exibem pacotinhos de conteúdo não identificado, de diversas cores e texturas. Outros/as trazem ovos, uma bacia de cozinha, uma colher ou uma forma de assar. Ingredientes e utensílios para preparar um bolo de chocolate. A aula de matemática torna-se o espaço-tempo da partilha - cada um traz um ingrediente para contribuir - e da experimentação. Devirescozinheiros/as, mobilizados em compor, acrescentando, cada um/uma, uma ajuda, um ingrediente, um aprendizado: compondo um bolo-acontecimento.

Em tempo, a professora justifica a proposta da aula fazendo referência a um conteúdo do currículo de matemática: "Eles estão estudando proporções". E se perguntássemos aos/às estudantes o que aprenderam ao invés de nos preocuparmos em saber o que se tentou ensinar? (LARROSA, 2016).

Compor um currículo criando conexões, mas se mantendo sempre aberto. Conexões entre conteúdos e também com o que é vivido seja dentro da escola ou fora dela.

\subsection{APRENDER}

A ação pedagógica e a aprendizagem se afastaram do controle do/da professor/a sobre os/as estudantes, para a multiplicação dos vetores de ação e interação.

O projeto provocou exposição, em inúmeros sentidos, mobilizou ideias, estabeleceu mudanças nas relações, provocou novas formas de envolvimento, proposição e participação. Em alguns dos depoimentos produzidos pela pesquisa foi apontado esse aspecto da relação entre os participantes:

- Todos [juntos] fazendo funcionar. (PT)

- A gente começou pensando junto, a gente participou junto, era um grupo bem unido. Aprendemos a trabalhar juntos. A gente teria que funcionar numa equipe, não sendo individual, sendo todos juntos, todos fazendo funcionar. (IS)

- O diferente disso foi estar amarrado que eu [professora] não ia propor! (DN)

- Eu [professora] não entendia nada sobre o assunto que eu fiquei responsável; inverteu a situação, eu não tinha a obrigação de ser aquela pessoa que sabia muito. (JS)

E estar atento ao outro passou a fazer parte do modo de funcionamento dos grupos no projeto.

- A gente pensa que os alunos são incapazes, e no fim, a gente se surpreende, porque eles dão as ideias. (DN)

- Eu não esperava que eles [alunos] tivessem tanto conhecimento assim. (JS)

- Com o projeto, você percebe: 'eu não sou tão ignorante quanto eu imaginava que era!' (DN)

- Acho que seria [foi] interessante... eles [alunos] se envolveriam [envolveram] mais um com o outro. (JT)

- Isso foi legal, as descobertas deles, o envolvimento. (DN)

Uma das professoras conclui “É estimulante para o aluno" (JS). Sobretudo, porque a participação nas escolhas e encaminhamentos das ações envolveram os participantes como um todo em diversos grupos, como pode ser observado em trechos dos depoimentos:

- Vai de encontro com aquilo que eles querem. Partiu deles a ideia do jornal; a ideia da pesquisa. (DN)

- Todo mundo [do grupo] de literatura queria fazer o teatro aqui na escola. (AR)

- Alguns fizeram os bonecos, alguns ficaram responsabilizados pelo jornalzinho; eu fiz a parte do boneco. (VH)

Mesmo com fragilidades e desvios...

- Tinha um monte de ideias bonitinhas, um monte de ideias legais, tinha umas "nada a ver" também. (AC)

-Na época, os colegas [professores] davam risada da minha cara, porque eu fiquei com um grupo que tinha alunos que eram vistos pela escola com aqueles que faziam muita bagunça, faziam muito 'fervo', e bem no fim, eles surpreenderam bastante, o "trabalhar com eles'. (SM) 
Nesse processo, o/a professor/a é indagado/a sobre o seu "papel", percebe que não está sozinho/a, mas que pode "trabalhar com" e que cada um/uma pode contribuir e/ou buscar seus caminhos. Como é apontado por Jorge Larrosa, o/a professor/a pode buscar ensinar uma relação com o texto, marcada pela escuta, pela abertura e pela inquietude, para então "manter aberto um espaço em que cada um possa encontrar sua própria inquietude” (LARROSA, 2007, p. 147).

Ou seja, o/a professor/a mantém-se ativo, propondo e contribuindo, mas sem limitar, e sim criar aberturas. E desse modo, dar a pensar, colocar uma matéria em movimento. Assim como afirma Peter Pelbart a respeito de uma aula: "não se trata de transmitir uma informação, ou uma técnica de análise, mas de trabalhar uma matéria em movimento - a matéria-pensamento" (PELBART, 2005, p. 9). Como descrito por uma das participantes:

- Ele [professor] chegou lá e já tinha pesquisado do assunto. Foi isso que eu falei da (sic) gente trazer, porque o assunto envolve; todo mundo vai se interessando e quer trazer alguma coisa de fora. Foi o que ele fez, trouxe a pesquisa sobre as latinhas. [Uma] menina falou do grupo de refugiados que mora aqui perto, que daria para ajudar. [...] a gente não conseguiu nada e eis que acabou o ano e a gente não conseguiu desenvolver. Mas só esse ganho de conhecimento foi muito forte. (IS)

Segundo esse relato do grupo de Meio Ambiente, o professor havia pesquisado e, ao encontrar o grupo, apresentou a ideia deixando-a em aberto. A estudante, participante do grupo, criou uma conexão possível entre a arrecadação de alumínio sugerida e as demandas da comunidade em que vive.

Movimento e atitude como as de um pirata, que "se expõe atravessando um espaço indeterminado e perigoso, pondo-se nele à prova e buscando nele sua oportunidade, sua ocasião" (LARROSA, 2002, p. 25). 0 compromisso estabelecido no contato entre os participantes dos grupos contagiava e mobilizava cada um a buscar aquilo que tivesse algum sentido para si, buscando contribuir para o trabalho coletivo.

- ... a ideia que movia o grupo aproximava, fazia correr atrás. Eu achei legal a gente ir atrás, a gente correr atrás, só para ter essa noção. [...] A gente correu atrás... a gente correr atrás juntos, como grupo. (IS)

- Daí a gente começou a correr atrás! [...] a gente estava correndo atrás de algumas coisas. (SM)

\subsection{CONTAGIAR: PROCESSOS DE FORMAÇÕES}

O projeto "A escola que queremos" potencializou, com esses encontros, o traçado de caminhos para se aprender no contato com outrem, com o desconhecido, com a diferença.

- Todo e qualquer trabalho que envolva a nossa convivência com outras pessoas, que a gente tenha que desenvolver algo maior, acima da nossa diferença pessoal, traz um ganho enorme. (IS)

Os processos de formação, se pensados enquanto possibilidade de devir outro, podem envolver aprendizagens por contágio. Aprendizagens que podem envolver aberturas para outros possíveis, pois "a estrutura que outrem confere a minha percepção é justamente a estrutura do possível. Outrem exprime um mundo possível que tem uma realidade determinada, não é apenas uma abstração" (SILVA; KASPER, 2014, p. 721).

Os grupos temáticos do projeto ocuparam o (seu) espaço e o tempo. Provocaram vibrações. Fizeram a (sua) voz ecoar. Permitiram vislumbrar possibilidades: contágios, aprendizagens, (de)formações, devires.

Possíveis emergem - e puderam emergir - ao se romper a harmonia dada pela consciência sobre o que deve e possa ser a escola; apontando múltiplas possibilidades do que pode vir a ser. Encontrar na própria educação possibilidades e desvios (LEITE, 2011), nem sempre bem-vindos, mas que possam causar deslocamentos, (re)invenções.

\section{REFERÊNCIAS}

[1] Gallo, Silvio. Em torno de uma educação menor. Educação e Realidade, n. 27 (2), 2002.

[2] _ _ Educação menor: produção de heterotopias no espaço escolar. In: Grupo Transversal. Educação menor: conceitos e experimentações. 2 ed. Curitiba: Appris, 2015.

[3] Larrosa, Jorge. Notas sobre a experiência e o saber de experiência. Revista Brasileira de Educação, n. 19, p. 20-28. jan/fev/mar/abr 2002.

[4] Nietzsche \& a educação. Tradução de Semíramis Gorini da Veiga. Belo Horizonte: Autêntica, 2005. 
[5] _ Literatura, experiência e formação: uma entrevista com Jorge Larrosa. Tradução de Alfredo Veiga-Neto. In: Costa, Marisa Vorraber. (org.) Caminhos investigativos I: novos olhares na pesquisa em educação. 3a ed. Rio de Janeiro: Lamparina, 2007. p. 129-156.

[6] _ Tremores: escritos sobre experiência. Tradução de Cristina Antunes e João Wanderley Geraldi. Belo Horizonte: Autêntica, 2016.

[7] Leite, César Donizetti Pereira. Infância, experiência e tempo. São Paulo: Cultura Acadêmica, 2011. Disponível em: http://www.ufjf.br/pensandobem/files/2016/05/infancia_experiencia_e_tempo.pdf. Acesso em: 09 set. 2019

[8] Pelbart, Peter Pál. Deleuze e a educação. In: Abramowicz, Anete; Silvério, Valter R. (org) Afirmando diferenças. Campinas: Papirus, 2005.

[9] Silva, Cíntia Vieira; Kasper, Kátia Maria. Diferença como abertura de mundos possíveis: aprendizagem e alteridade. Uberlândia: UFU. Revista Educação e Filosofia, v. 28, n. 56, p. 711-728, jul/dez 2014. Disponível em: http://www.seer.ufu.br/index.php/EducacaoFilosofia/article/view/22815/15318. Acesso em: 09 set. 2019.

[10] Silva, Tomaz Tadeu. Documentos de identidade: uma introdução às teorias do currículo. Belo Horizonte: Autêntica, 2002. 


\section{Capítulo 13}

Formação e práticas docentes em contextos de educação não formal e suas relações nos documentos oficiais da educação brasileira

\section{Daniela Tomio \\ Rocheli Rita Ronchi \\ Vanderlei Schmitz}

Resumo: Esta pesquisa foi desenvolvida com o objetivo de elucidar relações entre a formação e a prática docente com a Educação Não Formal nas determinações e orientações de documentos oficiais da Educação brasileira. Dentre os textos para análise, elegemos as Diretrizes Curriculares Nacionais Gerais para a Educação Básica (BRASIL, 2010); as Diretrizes Curriculares Nacionais para a formação inicial em nível superior [...]e para a formação continuada (BRASIL, 2015) e o Plano Nacional de Educação (BRASIL, 2014). 0 percurso investigativo consistiu em uma pesquisa exploratória e documental, com a seleção de excertos dos documentos. Na leitura dos textos foram destacadas todas menções às expressões educação não formal, educação não escolar e educação extra classe, também referências aos contextos distintos da educação formal (escola e educação superior). Na sequência, foram copiados os excertos dos documentos que atendessem a esses requisitos em sua enunciação. A análise documental foi desenvolvida, considerando procedimentos previstos por Cellard (2008), decidindo categorias a posteriori. Foram identificadas onze citações e sistematizadas em três categorias: ampliação da jornada escolar; qualidade social da escola e das instituições de Educação Superior e a expansão do espaço público da Educação. A partir disso, consideramos, com base em nosso referencial teórico, que as orientações e determinações nas legislações são afirmativas nas relações entre processos de Educação Formal, nas práticas e formação docente, e os contextos de Educação Não Formal. Por outro lado, a pouca explicitação literal dos termos "educação não formal" ou "educação não escolar" silencia seu lugar no discurso e fragiliza seu reconhecimento como contexto de práticas educativas e, portanto, de emergência para formação de professores que nela atuam. A Educação Não Formal no Brasil já é um contexto de docência. A sua reflexão acerca da formação de professores constitui um campo de conhecimento em construção.

Palavras-chave: Educação Não-formal. Legislação educacional. Formação docente. Práticas Educativas. 


\section{INTRODUÇÃO}

Esta pesquisa é desenvolvida de forma a articular compreensões acerca da Educação Não Formal (ENF) e suas interfaces com a formação e a prática docente, tendo como objeto de análise sentidos atribuídos a este contexto em documentos oficiais da educação brasileira.

"O século XXI é cenário de novas configurações pedagógicas que criam e recriam diferentes possibilidades de ensinar e aprender, tornando ainda mais complexo o significado e as formas de educação". (SEVERO, 2015, p. 563). Nesta direção, "sem negar o potencial e a especificidade da escola, as práticas educativas não escolares adquirem relevância no contexto de um projeto de sociedade em que a aprendizagem e o conhecimento ocupam lugares centrais". (SEVERO, 2015, p. 564).

Nossa compreensão de Educação aqui expressa transcende a educação escolarizada. Discutimos sentidos para relações dos sujeitos (professores e estudantes) com o saber por meio de outras práticas educativas, desenvolvidas em cenários como museus, galerias de arte, parques ecológicos, zoológicos, jardins botânicos, clubes de ciências, bibliotecas públicas, projetos socioeducativos em Organizações Não Governamentais (ONGs), dentre outros. Em comum, estes contextos podem oportunizar experiências de Educação (não formais) que

[...] não tem o caráter formal dos processos escolares, normatizados por instituiç̃ões superiores oficiais e certificadores de titularidades. Difere da educação formal porque esta última possui uma legislação nacional que normatiza critérios e procedimentos específicos. [...] Destaca-se que a educação não formal lida com outra lógica nas categorias espaço e tempo [...]. (GOHN, 2010, p. 22)

Em outras palavras, "a educação não-formal é também uma atividade educacional organizada e sistemática, mas levada a efeito fora do sistema formal". (GADOTTI, 2005, p. 2).

Distintos da educação formal (escolar), os contextos de ENF também podem ser valorizados pela possibilidade de contribuírem para formação dos estudantes e professores, pois, como sugere Castro (2015, p.182-3), cada uma dessas "têm seus próprios objetivos, conteúdos, referências teóricas, metodologias e embates internos nos seus campos". No entanto, quando consideramos suas contribuições "na perspectiva da Formação Integral, são todas igualmente necessárias e integradoras". Ainda, compartilhamos com a autora a noção de que:

A diferenciação entre Educação Formal e a Educação Não Formal não deveria ser feita a partir de elementos que a escola ou espaços formais deveriam levar e consideração e respeitar. Mas, sim, por atribuições indispensáveis a cada tipo de Educação, que caracterizariam determinadas atividades de forma que só pudessem ser realizadas em espaços formais ou não formais. (CASTRO, 2015, p. 174, grifo nosso)

Estudos evidenciam que o perfil profissional dos sujeitos que atuam em contextos de ENF (como docentes, instrutores ou mediadores científicos e culturais.) são, em sua grande maioria, habilitados em diferentes licenciaturas. Também Zucchetti (2012, p. 138) destaca que “[...] há de se considerar que dados empíricos de pesquisas diversas, na área, demonstram que a maioria dos educadores sociais ou são acadêmicos de licenciaturas ou professores graduados."

Com base nisso, inferimos que a ENF é contexto onde também atuam professores configurando-se então em lócus profissional de práticas docentes com suas especificidades. Desse modo, na medida em que a oferta de espaços de educação se ampliam, compartilhamos das ideias de Gohn (2010) e Zucchetti (2012, p. 138) de que "estamos diante da necessidade de refletirmos sobre qual conceito precisamos amparar a formação desses atores sociais", os professores. Além desta lacuna, Severo (2015) alerta que ainda é baixo o nível de preocupação da comunidade acadêmica em explorar os sentidos que a expressão Educação Não Formal representa.

Diante destas premissas, objetivamos com esta pesquisa elucidar relações entre a formação e a prática docente com a Educação Não Formal nas determinaç̧ões e orientações de documentos oficiais da Educação brasileira.

Dentre os documentos elegemos como objetos de estudo as Diretrizes Curriculares Nacionais Gerais para a Educação Básica (BRASIL, 2010); as Diretrizes Curriculares Nacionais para a formação inicial em nível superior (cursos de licenciatura, cursos de formação pedagógica para graduados e cursos de segunda 
licenciatura) e para a formação continuada (BRASIL, 2015) e o Plano Nacional de Educação (BRASIL, 2014).

Justificamos nossa opção por articular a formação e prática docente com a educação não formal a partir de uma análise da legislação brasileira, compartilhando das ideias de Azevedo (1996, p. 561) ao afirmar que “[...] um dos mais preciosos documentos para o estudo da evolução de uma sociedade e do caráter de uma civilização se encontra na legislação escolar [...]”, Ainda, como destaca Faria Junior (1998, p. 115):

[...] muito mais do que temos pensado, a lei está intimamente ligada a determinadas formas de concepção de escola, concepções estas que são produzidas no interior dos parlamentos ou de alguma outra instância do Estado, mas apropriadas, de maneiras mais diversas, pelos diferentes sujeitos ligados à produção e à realização da legislação.

Inferimos que esta elucidação é relevante para elaborarmos indícios a fim de problematizarmos o lugar que esta dimensão da Educação é prevista na formação inicial e continuada, bem como na prática docente no atual contexto histórico-social em que a Educação Não Formal amplia sua frequência no cenário educacional nacional.

Importante, também, destacar que este estudo complementa um conjunto de atividades de pesquisa e extensão de um projeto maior, intitulado "Contextos (não formais) de formação e práticas docentes na Educação Básica: contribuições para o desenvolvimento profissional”, desenvolvido por um coletivo de estudantes e professores da graduação e pós-graduação (PPGE e PPGECIM) e professores da educação básica na Universidade Regional de Blumenau (FURB).

\section{PERCURSO DE INVESTIGAÇÃO}

A pesquisa se caracteriza em relação a natureza do problema investigado, como uma pesquisa qualitativa e tem como método a análise documental, considerando os documentos como fontes de investigação para compreensão de uma história "recente".

Compartilhamos do conceito de documento, sistematizado por Le Goff (1992, p. 545), como "um produto da sociedade que o fabricou segundo as relações de forças que aí detinham o poder", por tanto é um produto social. Ainda, como sujeitos pesquisadores, nossa interpretação dos dados não é neutra, é mediada pelo estilo de pensamento dos coletivos com os quais circulamos ideias e práticas sobre Educação, Formação de Professores e Educação Não Formal. Cientes desta posição de leitores de um documento, descrevemos os procedimentos abordados na análise documental:

\section{AS FONTES DOCUMENTAIS}

Selecionamos para análise as Diretrizes Curriculares Nacionais Gerais para a Educação Básica (BRASIL, 2010) que têm como objetivos:

I - sistematizar os princípios e as diretrizes gerais da Educação Básica contidos na Constituição, na Lei de Diretrizes e Bases da Educação Nacional (LDB) e demais dispositivos legais, traduzindo-os em orientações que contribuam para assegurar a formação básica comum nacional, tendo como foco os sujeitos que dão vida ao currículo e à escola; II - estimular a reflexão crítica e propositiva que deve subsidiar a formulação, a execução e a avaliação do projeto políticopedagógico da escola de Educação Básica; III - orientar os cursos de formação inicial e continuada de docentes e demais profissionais da Educação Básica, os sistemas educativos dos diferentes entes federados e as escolas que os integram, indistintamente da rede a que pertençam. (BRASIL, 2010, p. 1, grifo nosso)

Outro documento investigado foram as Diretrizes Curriculares Nacionais para a formação inicial em nível superior (cursos de licenciatura, cursos de formação pedagógica para graduados e cursos de segunda licenciatura) e para a formação continuada (BRASIL, RESOLUÇÃO № 2, DE 1o DE JULHO DE 2015) que contemplam: "[...] princípios, fundamentos, dinâmica formativa e procedimentos a serem observados nas políticas, na gestão e nos programas e cursos de formação, bem como no planejamento, nos processos de avaliação e de regulação das instituições de educação que as ofertam". (BRASIL, 2015, p 2-3, grifo nosso) 
Ainda, consultamos as metas e estratégias previstas no Plano Nacional da Educação 2014-2024 (BRASIL, LEI № 13.005, DE 25 DE JUNHO DE 2014), que consiste em "um instrumento de planejamento do nosso Estado democrático de direito que orienta a execução e o aprimoramento de políticas públicas do setor". (BRASIL, 2014, p.8).

\section{A GERAÇÃO DE DADOS}

Miguel (2006, p. 2) destaca como critérios para o trabalho com a legislação educacional: “0 trato com as fontes, dentre as quais a legislação, se inicia pelo levantamento das mesmas, procedendo à sua seleção criteriosa, mediante a leitura atenta dos documentos em relação ao objeto da pesquisa, buscando resposta a um problema".

Nesta direção, inicialmente realizamos a leitura dos três documentos - definidos como nossas fontes da legislação educacional a ser investigada, buscando responder quais relações entre a formação e a prática docente com a Educação Não Formal (ENF) podem ser elucidadas nas determinações e orientações de documentos oficiais da Educação brasileira?

Na leitura dos textos foram destacadas todas menções as expressões educação não formal, educação não escolar e educação extra classe, também referências aos contextos distintos da educação formal (escola e educação superior). Na sequência, foram copiados os excertos dos documentos que atendessem a esses requisitos em sua enunciação.

A análise documental foi desenvolvida, considerando procedimentos previstos por Cellard (2008), ao decidir as categorias de análises que podem surgir a posteriori. Depois de obter um conjunto inicial de categorias, a próxima fase envolve um enriquecimento do sistema mediante um processo divergente, incluindo as seguintes estratégias: aprofundamento, ligação e ampliação. Estas estratégias foram realizadas na relação com o nosso referencial teórico.

\section{SENTIDOS ATRIBUÍDOS PARA ENF NOS DOCUMENTOS OFICIAIS DA EDUCAÇÃO FORMAL}

A partir da leitura dos três documentos foram selecionadas as citações que estabelecemos relações com a Educação Não Formal. De cada citação identificada, realizamos a interpretação utilizando dois marcadores nos textos: o sublinhado para o termo e o itálico para o contexto da enunciação, ou seja, as suas relações com o conceito educação não formal. Podemos observar marcas favoráveis às relações da Educação Não Formal com a Educação Formal nas orientações pertinentes a organização da Educação Básica e Formação docente, conforme os excertos abaixo:

\section{Diretrizes Curriculares Nacionais Gerais para a Educação Básica}

Identificamos na leitura do documento quatro alusões à Educação Não Formal, destacadas nos excertos 1, 2, 3 e 4:

\section{Excerto 1- Artigo 9을}

"A escola de qualidade social adota como centralidade o estudante e a aprendizagem, o que pressupõe atendimento aos seguintes requisitos: I - revisão das referências conceituais quanto aos diferentes espaços e tempos educativos, abrangendo espaços sociais na escola e fora dela; [...]." (BRASIL, 2010, p. 3, grifo nosso).

Excerto 2- Art. 9:

“[...] IX - realização de parceria com órgãos, tais como os de assistência social e desenvolvimento humano, cidadania, ciência e tecnologia, esporte, turismo, cultura e arte, saúde, meio ambiente." (BRASIL, 2010, p. 3, grifos nosso).

Excerto 3 - Artigo 12:

Cabe aos sistemas educacionais, em geral, definir o programa de escolas de tempo [...] tendo em vista a amplitude do papel socioeducativo atribuído ao conjunto orgânico da Educação Básica, o que requer outra organização e gestão do trabalho pedagógico.

§ 1ํ Deve-se ampliar a jornada escolar, em único ou diferentes espaços educativos, nos quais a permanência do estudante vincula-se tanto à quantidade e qualidade do tempo diário de escolarização quanto à diversidade de atividades de aprendizagens. [...]. (BRASIL, 2010, p. 4, grifo nosso). 
Excerto 4 - Artigo 13:

\section{O currículo [...]}

3ํ A organização do percurso formativo, aberto e contextualizado, deve ser construída em função das peculiaridades do meio e das características, interesses e necessidades dos estudantes, incluindo não só os componentes curriculares centrais obrigatórios, previstos na legislação e nas normas educacionais, mas outros, também, de modo flexível e variável, conforme cada projeto escolar, e assegurando:

I - concepção e organização do espaço curricular e físico que se imbriquem e alarguem, incluindo espaços, ambientes e equipamentos que não apenas as salas de aula da escola, mas, igualmente, os espaços de outras escolas e os socioculturais e esportivo recreativos do entorno, da cidade e mesmo da região;

II - ampliação e diversificação dos tempos e espaços curriculares que pressuponham profissionais da educação dispostos a inventar e construir a escola de qualidade social, com responsabilidade compartilhada com as demais autoridades que respondem pela gestão dos órgãos do poder público, na busca de parcerias possíveis e necessárias, até porque educar é responsabilidade da família, do Estado e da sociedade. (BRASIL, 2010, p. 4, grifo nosso).

Diretrizes Curriculares Nacionais para a formação inicial em nível superior (cursos de licenciatura, cursos de formação pedagógica para graduados e cursos de segunda licenciatura) e para a formação continuada

$\mathrm{Na}$ leitura foram observadas quatro referências às articulações entre espaços formais de formação e práticas docentes (especialmente na escola e instituição de educação superior) com a Educação Não Formal, citando: outros ambientes, outras áreas nas quais sejam previstos conhecimentos pedagógicos, outras instituições educativas e, em destaque, processos educativos não escolares. Estes podem ser lidos nos excertos 5, 6, 7 e 8:

\section{Excerto 5 - Artigo 7ํㅜㅇ}

$\mathrm{O}(\mathrm{A})$ egresso(a) da formação inicial e continuada deverá possuir um repertório de informações e habilidades composto pela pluralidade de conhecimentos teóricos e práticos, resultado do projeto pedagógico e do percurso formativo vivenciado cuja consolidação virá do seu exercício profissional, [...] de modo a lhe permitir:

\section{$[\cdots]$}

III - planejamento e execução de atividades nos espaços formativos (instituições de educação básica e de educação superior, agregando outros ambientes culturais, científicos e tecnológicos, físicos e virtuais que ampliem as oportunidades de construção de conhecimento), desenvolvidas em níveis crescentes de complexidade em direção à autonomia do estudante em formação; [...]. (BRASIL, 2015, p. 7, grifo nosso).

Excerto 6 - Artigo 10:

A formação inicial destina-se àqueles que pretendem exercer o magistério da educação básica em suas etapas e modalidades de educação e em outras áreas nas quais sejam previstos conhecimentos pedagógicos, compreendendo a articulação entre estudos teórico-práticos, investigação e reflexão crítica, aproveitamento da formação e experiências anteriores em instituições de ensino. (BRASIL, 2015, p. 9, grifo nosso). 
Excerto 7 - Artigo 12:

III - núcleo de estudos integradores para enriquecimento curricular, compreendendo a participação em: [...] b) atividades práticas articuladas entre os sistemas de ensino e instituições educativas de modo a propiciar vivências nas diferentes áreas do campo educacional, assegurando aprofundamento $e$ diversificação de estudos, experiências e utilização de recursos pedagógicos; [...]. (BRASIL, 2015, p. 10, grifo nosso).

Excerto 8 - Artigo 13:

Os cursos de formação inicial de professores para a educação básica em nível superior, em cursos de licenciatura, organizados em áreas especializadas, por componente curricular ou por campo de conhecimento e/ou interdisciplinar, considerando-se a complexidade e multirreferencialidade dos estudos que os englobam, bem como a formação para o exercício integrado e indissociável da docência na educação básica, incluindo o ensino e a gestão educacional, e dos processos educativos escolares e não escolares, da produção e difusão do conhecimento científico, tecnológico e educacional, estruturam-se por meio da garantia de base comum nacional das orientações curriculares. (BRASIL, 2015, p. 11, grifo nosso).

\section{Plano Nacional da Educação}

Para seleção dos excertos deste documento foram consideradas principalmente as metas e respectivas estratégias, previstas no anexo da lei, a serem cumpridas no prazo de vigência do PNE.

Embora não tenhamos encontrado a expressão "Educação Não Formal”, interpretamos três relações a este contexto de educação, especialmente nas estratégias, como se pode apreciar nos excertos 9, 10 e 11:

\section{Excerto 9 - Meta 2:}

"universalizar o ensino fundamental de 9 (nove) anos para toda a população de 6 (seis) a 14 (quatorze) anos e garantir que pelo menos $95 \%$ (noventa e cinco por cento) dos alunos concluam essa etapa na idade recomendada, até o último ano de vigência deste PNE." (BRASIL, 2014, p. 50, grifo nosso).

Estratégia - 2.8:

2.8. promover a relação das escolas com instituições e movimentos culturais, a fim de garantir a oferta regular de atividades culturais para a livre fruição dos (as) alunos (as) dentro e fora dos espaços escolares, assegurando ainda que as escolas se tornem polos de criação e difusão cultural; [...]. (BRASIL, 2014, p. 50, grifo nosso).

\section{Excerto 10 - Meta 6:}

"Oferecer educação em tempo integral em, no mínimo, 50\% (cinquenta por cento) das escolas públicas, de forma a atender, pelo menos, 25\% (vinte e cinco por cento) dos (as) alunos (as) da educação básica." (BRASIL, 2014, p. 59, grifo nosso).

\section{Estratégia - 6.4:}

“6.4. fomentar a articulação da escola com os diferentes espaços educativos, culturais e esportivos e com equipamentos públicos, como centros comunitários, bibliotecas, praças, parques, museus, teatros, cinemas e planetários; [...]". (BRASIL, 2014, p. 60, grifo nosso).

\section{Excerto 11 - Meta 7:}

"Fomentar a qualidade da educação básica em todas as etapas e modalidades, com melhoria do fluxo escolar e da aprendizagem de modo a atingir as seguintes médias nacionais para o Ideb:" (BRASIL, 2014, p. 61, grifo nosso). 
Estratégias - 7.28

7.28. mobilizar as famílias e setores da sociedade civil, articulando a educação formal com experiências de educação popular e cidadã, com os propósitos de que a educação seja assumida como responsabilidade de todos e de ampliar o controle social sobre o cumprimento das políticas públicas educacionais. (BRASIL, 2014, p. 66, grifo nosso).

Com base nas marcas que destacamos nos textos das legislações, interpretamos que os documentos oficiais que normatizam e orientam a atividade educacional em território nacional, especialmente na formação e prática docente, expressam articulações à ENF, principalmente no que concerne relações que sistematizamos em três categorias, expressas na figura 1:

Figura 1- Categorias de relações entre a EF e ENF analisadas nos documentos

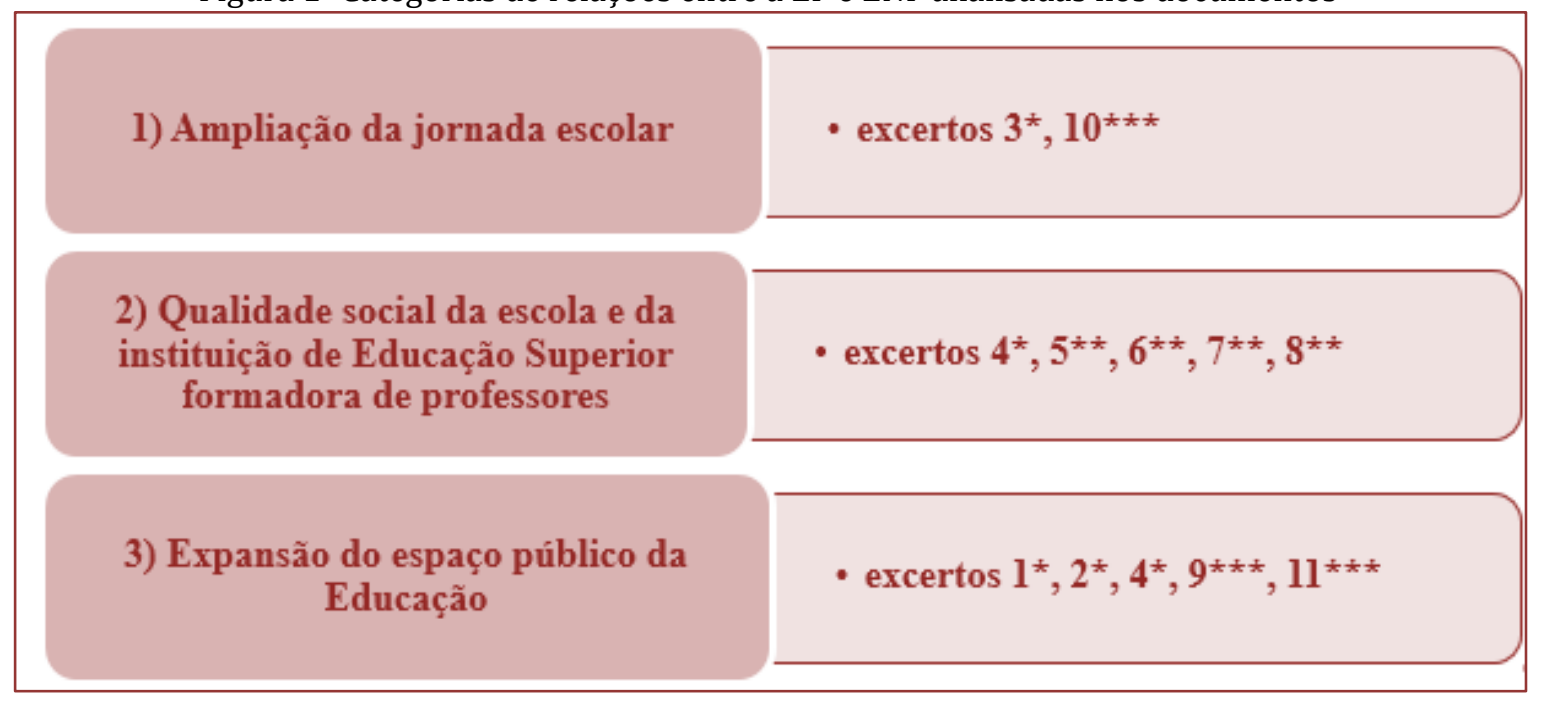

*DCN Educação Básica; ** DCN Formação docente; ***PNE

Fonte: Elaborado pelos pesquisadores

Na primeira categoria, observamos que a legislação prevê uma articulação da Escola com a ENF considerando as possibilidades de diferentes espaços educativos (Excerto 3) e diferentes espaços educativos, culturais e esportivos e com equipamentos públicos, como centros comunitários, bibliotecas, praças, parques, museus, teatros, cinemas e planetários (Excerto 10) para ampliação da jornada escolar em tempo integral.

Com isso, os documentos orientam que nestes contextos é preciso prever a permanência dos estudantes vinculando "à diversidade de atividades de aprendizagens". (Excerto 10). Nesta direção, entendemos como Gohn (2010, p. 41) de que "o ideal é que a educação não formal seja complementar - não no sentido de fazer o que a escola deveria fazer e não faz. Complementar no sentido de aprendizagens e saberes que lhes são específicos." Aponta ainda que "os programas e projetos da educação não formal devem cruzar, atuar e potencializar a educação formal, não como mera complementação mas como diretriz estruturante." (GOHN, 2014, p. 42)

Em outras palavras, é preciso atuar em complementaridade e parceria, sem perder as especificidades pertencentes a cada organização na formação integral do estudante. Isto traz, também, desafios e perspectivas para pensar a formação docente uma vez que estudos demonstram que os professores que atuam em contextos de ENF "[...] tendem a arrastar para a educação, no campo social, o modo de socialização escolar [...] o modelo de formação recebido por tais professores ainda está centrado na educação escolar. (ZUCCHETTI, 2012, p. 138).

Na segunda categoria, qualidade social da escola e das instituição de Educação Superior, reunimos relações com a ENF, quando os documentos se referem à concepção e organização do espaço curricular e físico para formação dos estudantes e professores, orientando que se imbriquem e alarguem, incluindo espaços, ambientes socioculturais e esportivo recreativos do entorno, da cidade e mesmo da região (Excerto 4); agregando outros ambientes culturais, científicos e tecnológicos, físicos e virtuais (Excerto 5) e, também, 
fora dos espaços escolares (Excerto 9) ou em processos educativos não escolares. (Excerto 8), prevendo a prática profissional docente em outras áreas nas quais sejam previstos conhecimentos pedagógicos (Excerto 6).

Nestas acepções, inferimos que os documentos estabelecem relações para ENF como oportunidades para práticas educativas que possibilitem aos estudantes: ampliarem construção de conhecimento (Excerto 5); atividades culturais para a livre fruição (Excerto 9) e melhoria do fluxo escolar e da aprendizagem (Excerto 11).

Não foi possível observar nos documentos nenhuma relação da ENF e a formação continuada de professores. Já, na formação inicial docente, as relações com os contextos de ENF estão associadas às oportunidades do futuro docente: na direção à autonomia (Excerto 5); compreender a articulação entre estudos teórico-práticos, investigação e reflexão crítica, aproveitamento da formação e experiências anteriores em instituições de ensino. (Excerto 6); de modo a propiciar vivências nas diferentes áreas do campo educacional, assegurando aprofundamento e diversificação de estudos, experiências e utilização de recursos pedagógicos (Excerto 7).

Tais relações nos desafiam a refletir os processos de formação de professores nas instituições de Ensino Superior e de como tem sido estabelecidas parcerias com os contextos de ENF. Como destaca Nóvoa (2009, p. 88) "hoje, é necessário mobilizar [...] novas energias na criação de ambientes educativos inovadores, de espaços de aprendizagem que estejam à altura dos desafios da contemporaneidade." E nesta direção,

[...] acredita-se que, à medida em que os Cursos de Formação de Professores, em especial, os de Pedagogia, passem a contemplar, na sua formação, um conceito ampliado de educação, isto possa ser relativizado. Há muitos lugares para aprender e a ideia hegemônica que a educação acontece somente no interior da escola produz um saber-poder determinante. 0 reconhecimento destes outros lugares de aprendizagem e uma formação de professores que os contemple poderá contribuir para um novo professor. (MOURA; ZUCHETTI, 2014, p.350).

Por fim, sistematizamos a terceira categoria, observando que a legislação prevê uma articulação da Educação Formal com a ENF considerando a expansão do espaço público da Educação na realização de parceria com órgãos, tais como os de assistência social e desenvolvimento humano, cidadania, ciência e tecnologia, esporte, turismo, cultura e arte, saúde, meio ambiente. (Excerto 2); com responsabilidade compartilhada com as demais autoridades (Excerto 4); na relação com instituições e movimentos culturais (Excerto 9), na mobilização das famílias e setores da sociedade civil, articulando a educação formal com experiências de educação popular e cidadã (Excerto 11). Com isso, os documentos, em especial o PNE, justifica: "com os propósitos de que a educação seja assumida como responsabilidade de todos e de ampliar o controle social sobre o cumprimento das políticas públicas educacionais”. (BRASIL, 2014, p. 9).

Interpretamos tal orientação do documento, com base na proposta de Nóvoa (2009):

Sem ignorar o papel da escola em muitas destas missões, será que elas não devem ser assumidas primordialmente por outras instâncias sociais? Será que não devemos responsabilizar as famílias, mas também as comunidades locais, as associações culturais, as entidades laborais, as igrejas, os museus, as organizações científicas, os centros de saúde e os espaços artísticos e desportivos pelo cumprimento de boa parte destas missões? (NÓVOA, 2009, p. 89).

Não se trata de regressar ao debate sobre a relação escola sociedade, mas antes de promover a construção de um espaço público de educação, no qual a escola tem o seu lugar, mas que não é um lugar hegemónico, único, na educação das crianças e dos jovens. A proposta que vos faço rompe com a tradição de ir atribuindo à escola todas as missões e inspira-se nas formas de convivialidade [...]. (NÓVOA, 2009, p. 90). 
A noção de formas de convivialidade entre a educação formal e a educação não formal na direção de um projeto comum de Educação, seja na formação do estudante ou da formação docente, é desafio que se impõe às atuais políticas e práticas educacionais. Neste sentido, a compreensão do que é "educação" no seu conceito mais complexo, traz à tona o entendimento de que aprender se dá além do processo de escolarização ou na universidade.

0 objetivo central precisa ser, portanto, reconhecermos que os processos considerados Educação Não Formal devem ser um direito porque são fundamentais para a formação humana em nossa sociedade. Assim, dando a eles o mesmo status da chamada Educação Formal, ou ainda, considerando-lhes parte de um mesmo processo formativo (CASTRO, 2015, p. 175)

Esse ponto de vista reforça o sentido orientador das práticas educativas em nossa contemporaneidade, valoriza a ação dos profissionais da educação que desenvolvem e constroem conhecimentos pedagógicos nos diversos contextos da educação formal e não formal e, portanto, traz desafios para formação docente de nosso tempo e futuro.

\section{CONSIDERAÇÕES FINAIS}

Ao olharmos para as fontes documentais, da legislação educacional, investigadas nesta pesquisa, concordamos com Castanha (2011, p. 326) de que em sua elaboração “[...] estão presentes utopias, sonhos, desejos, projetos políticos, interesses pessoais e de grupos, direitos e deveres dos cidadãos ou categorias profissionais, planos de carreiras, preconceitos, inclusões/exclusões, enfim, todas as contradições da sociedade". Da mesma forma, nossa leitura dos documentos já é uma interpretação, mediada por pressupostos que determinam uma maneira de compreender os textos.

Nesta direção, uma análise documental, como método de compreensão e produção do conhecimento acerca de um objeto de estudo da realidade sócio educacional, implica determinados recortes e tomada de posição. Em nosso caso, objetivamos com esta pesquisa elucidar relações entre a formação e a prática docente com a Educação Não Formal nas determinações e orientações de documentos oficiais da Educação brasileira. Buscamos uma primeira leitura, sem ampliar para conexões dos achados com o contexto de produção histórico-social-político da produção desses documentos, o que certamente possibilitaria constituir outras categorias e uma análise mais aprofundada.

Por outro lado, como destaca Bernet (2013, p. 33, tradução nossa), ao se referir a necessidade de formular novos conceitos com a ampliação da ENF em nossa sociedade: "O que não é chamado não existe. Para algo ter um lugar no discurso e para que possa ser reconhecido, na realidade, essa coisa deve ser chamada".

Assim, em nossa pesquisa exploratória, buscamos a interpretação dos excertos que selecionamos na leitura das Diretrizes Curriculares Nacionais Gerais para a Educação Básica (BRASIL, 2010); Diretrizes Curriculares Nacionais para a formação inicial em nível superior (cursos de licenciatura, cursos de formação pedagógica para graduados e cursos de segunda licenciatura) e para a formação continuada (BRASIL, 2015) e do Plano Nacional de Educação (BRASIL, 2014), permitindo compreender a "existência" de relações entre as práticas e formação docente e a Educação Não Formal.

Na sistematização dos achados, elaboramos as três categorias: ampliação da jornada escolar; qualidade social da escola e das instituição de Educação Superior e a expansão do espaço público da Educação. Com isso, consideramos que as orientações e determinações nas legislações são afirmativas nas relações entre processos de Educação Formal, nas práticas e formação docente, e os contextos de Educação Não Formal.

Por outro lado, a pouca explicitação literal dos termos "educação não formal" ou "educação não escolar" silencia seu lugar no discurso e fragiliza seu reconhecimento como contexto de práticas educativas e, portanto, de emergência para formação de professores que nela atuam. Cada vez mais, necessitam-se desenvolver oportunidades formativas “[...] capazes de incorporar propostas/orientações pedagógicas, sem o que, segundo Gohn, tendemos a constituir um tipo de educador que pouco contribui para a transformação da sociedade". (ZUCCHETTI, 2012, p. 138).

Por fim, intencionamos com o conhecimento elaborado nesta pesquisa sobre a ENF mobilizar a discussão às questões de nossa época, considerando uma sistematização de determinações e orientações de documentos legais da Educação brasileira. Não obstante, compreendemos que sem as condições materiais e de trabalho estas dificilmente poderão ser realizadas nos contextos educativos do nosso país. 
A Educação Não Formal no Brasil já é um contexto de docência. A sua reflexão acerca da formação de professores que nela atuarão constitui um campo de conhecimento em construção.

\section{REFERÊNCIAS}

[1] Azevedo, Fernando. As origens das instituições escolares. A cultura brasileira. 6. ed. Brasília: UnB, Rio de Janeiro: UFRJ, 1996.

[2] Bernet, J. T. La Educación No Formal. In: Uruguay- Ministerio de Educación y Cultura. Educación No Formal: Lugar de conocimientos: Selección de textos. Montevideo: Dirección de Educación del Mec, 2013. p. 27-51.

[3] Brasil. Conselho Nacional de Educação. Diretrizes Curriculares Nacionais Gerais para a Educação Básica. Resolução n. 4, de 13 de julho de 2010.

[4] Brasil. Plano Nacional de Educação 2014-2024 [recurso eletrônico]: Lei no 13.005, de 25 de junho de 2014, que aprova o Plano Nacional de Educação (PNE) e dá outras providências. Brasília: Câmara dos Deputados, Edições Câmara, 2014.

[5] Brasil. Conselho Nacional de Educação. Diretrizes Curriculares Nacionais para a formação inicial em nível superior (cursos de licenciatura, cursos de formação pedagógica para graduados e cursos de segunda licenciatura) e para a formação continuada. Resolução n. 2, de 1ํ de julho de 2015.

[6] Castanha, A. P. O uso da legislação educacional como fonte: orientações a partir do marxismo. Revista Histedbr On-line. Campinas, n. esp., p. 309-331, abr. 2011.

[7] Castro, F, R. Há sentido na educação não formal na perspectiva da formação integral? Museologia \& Interdisciplinaridade v. 4, n. 8, dez. 2015.

[8] Cellard, A. A análise documental. In: Poupart, Jean et al. A pesquisa qualitativa: enfoques Epistemológicos e metodológicos. Petrópolis: Vozes, 2008.

[9] Faria Filho, L. M. A legislação escolar como fonte para a História da Educação: uma tentativa de interpretação. In: ___. (Org.). Educação, modernidade e civilização: fontes e perspectivas de análises para a história da educação oitocentista. Belo Horizonte: Autêntica, 1998. p. 89-125.

[10] Gadotti, M. A questão da Educação Formal/Não Formal. Sion, Suisse, p. 1-11, out. 2005.

[11] Gohn, M. da G. Educação não formal e o educador social: atuação no desenvolvimento de projetos sociais. São Paulo: Cortez, 2010.

[12] __ Educação não formal, aprendizagens e saberes em processos participativos. Investigar em Educação, Porto, n. $\overline{1,2014 .}$

[13] Le Goff, J. História e Memória. 2. ed. Campinas: Editora da Unicamp, 1992.

[14] Miguel, M. E. B. A legislação educacional paranaense e a história da educação. In: Seminário Nacional do Histebr - Grupo de Estudos e Pesquisas "História, Sociedade e Educação no Brasil", 6, 1997. Anais... 1997. p. 676-683.

[15] Moura, E, P, G.; Zuchetti, D, T. Socialização escolar, educação não escolar e (con) formação de sujeitos. Revista Contrapontos, Itajaí, v. 14, n. 2, mai-ago 2014.

[16] Nóvoa, A. Professores imagens do futuro presente. Lisboa: Educa, 2009.

[17] Severo, J, L, R, L. Educação não escolar como campo de práticas pedagógicas. Revista Brasileira Estudos Pedagógicos [online]. Brasília, v. 96. n. 244, p. 561-576, set/dez. 2015

[18] Zucchetti, D. T. Educação, Porto Alegre, v. 35, n. 1, p. 137-138, jan./abr. 2012. 


\section{Capítulo 14}

O paradigma da complexidade na prática pedagógica do professor universitário

\section{Marlene de Oliveira}

Resumo: A definição do que deve ser estudado nas escolas, deve ser a de ampliar o conhecimento, pois ainda é fragmentado e deixa as disciplinas escolares separadas do conhecimento do cotidiano do professor e do aluno e do que faz parte de suas vidas. 0 modelo tradicional de educação não mais atende a necessidade de capacitação profissional no ensino superior, tornando necessária a busca de uma solução para atender a esse problema. A exigência desse mundo moderno exigem radicais mudanças do que vem sendo oferecido na maioria dos cursos superiores. Esta nova caminhada acadêmica permite perceber que a mudança da prática pedagógica dos professores depende do entendimento sobre os paradigmas da ciência, em especial o paradigma emergente ou da complexidade 0 processo metodológico adotado para este estudo segue uma abordagem qualitativa e como estratégia a pesquisa-ação que para professores demonstra-se interativa e reflexiva na sua prática profissional com a finalidade de interpretar sua realidade e poder intervir nela. 0 presente artigo busca refletir a prática pedagógica através da disciplina Paradigmas Educacionais na Prática Pedagógica do Programa de Pós Graduação de Mestrado e Doutourado em Educação da PUC/PR no primeiro semestre de 2012.

\section{Palavras-chave: Paradigma, Complexidade, Prática pedagógica}




\section{INTRODUÇÃO}

Há necessidade de uma ruptura dos antigos afazeres pedagógicos tradicionais que levavam alunos e professores a repetirem o que já foi estudado e determinado. A definição do que deve ser estudado nas escolas, deve ser a de ampliar o conhecimento, pois hoje ainda é fragmentado e deixa as disciplinas escolares separadas do conhecimento do cotidiano do professor e do aluno e do que faz parte de suas vidas. A sociedade está passando por transformações a nível global onde a competitividade acelerada com a inovação tecnológica e a valorização do Conhecimento (AGUIAR E FERREIRA, 2005) tornou necessária a adoção de uma política social que permita novas alternativas educacionais para o ensino superior.

É no ambiente educacional que a sociedade busca suprir a sua necessidade de capacitação para o mundo profissional, conforme relata Kenski (2007, p.19):

A escola representa na sociedade moderna o espaço de formação não apenas das gerações jovens, mas de todas as pessoas. Em um momento caracterizado por mudanças valores, as pessoas procuram na educação escolar a garantia de formação que lhes possibilite o domínio de conhecimentos e melhor qualidade de vida.

$\mathrm{Na}$ possibilidade de se construir uma prática pedagógica compatível com as necessidades de produzir conhecimentos críticos e reflexivos, (BEHRENS, 2008) propõe-se uma nova metodologia de ensino como ação didática. Esta nova caminhada acadêmica permite perceber que a mudança da prática pedagógica dos professores depende do entendimento sobre os paradigmas da ciência, em especial o paradigma emergente ou da complexidade. Nesse sentido, além da reflexão sobre os paradigmas que acompanham a prática docente, os professores precisam encontrar uma metodologia que venha atender os paradigmas inovadores.

O modelo tradicional de educação não mais atende a necessidade de capacitação profissional no ensino superior, tornando necessária a busca de uma solução para atender a esse problema. A exigência desse mundo moderno exigem radicais mudanças do que vem sendo oferecido na maioria dos cursos superiores. 0 presente artigo busca refletir a prática pedagógica através da disciplina Paradigmas Educacionais na Prática Pedagógica do Programa de Pós Graduação de Mestrado e Doutourado em Educação da PUC/PR no primeiro semestre de 2012.

\section{FUNDAMENTAÇÃO TEÓRICA}

A mudança de paradigma acontece quando a ciência do momento, não consegue mais dar conta de explicar os fenômenos estudados, então outro paradigma surge para suprir esta lacuna. 0 paradigma da complexidade surgiu no final do século passado quando se fez uso dos termos e conceitos da nova teoria de entendimento para se obter o novo modo de compreensão do funcionamento da célula, surgiu assim a idéia de transdisciplinaridade que é a base desse novo paradigma, sendo a auto-organização o conceito central do paradigma da complexidade, tendo como seu ponto fundamental o afastamento do determinismo e a acolhida das apreciações do outro.

Mas o que é um paradigma? Segundo Cardoso (1995:17) “O conceito de paradigma é um modelo de pensar e ser capaz de engendrar determinadas teorias e linhas de pensamento”, já para Capra (1196:25) "[...] paradigma consiste em várias ideias e valores [...] entre os quais a visão de universo como um sistema mecânico composto de blocos de construção elementares [... ] a visão da vida em sociedade como uma luta competitiva pela existência.." enquanto que para Khun (1196:25) o paradigma social é uma constelação de concepções, valores e percepções [...] compartilhadas por uma comunidade científica que dá uma visão particular da realidade".

\subsection{A CRISE DO PARADIGMA NEUWTONIANO-CARTESEANO}

Iniciamos o século XXI ainda influenciados pelas tendências do Século XX e XIX onde o método carteasiano com a forma de organizar o pensamento em uma mentalidade reducionista , com uma visão fragmentada do homem sobre sí mesmo, vivendo separado de sua mente e sentimentos.(BEHRENS, 2011a). 0 paradigma newtoneano-carteseano teve a sua importância para os avanços alcançados pela revolução industrial onde a experimentação e a ação pela razão priorizaram o intelecto em vez da emoção. Iniciamos este século com a caracterização da produção em massa recebida do século XX que levaram o homem a separar a ética, da razão e do sentimento. 
Com todo o avanço científico e a especialização alcançada em diversos setores de nossa sociedade, incluindo a educação, a visão racionalista e mecanicista, tem dominado a nossa cultura nos últimos trezentos anos. (BEHRENS, 2011b). A especialização, o homem fragmentado, os avanços eletrônicos e biomédicos, não trouxeram para o homem a igualdade, a plenitude, a harmonia nas relações familiares e sociais tampouco a sustentabilidade e o equilíbrio com o meio ambiente . Muito pelo contrário, se por um lado, as novas descobertas, com a produção e consumismo em massa, por outro lado o estresse, as doenças modernas, as angústias e o desamor, onde competividade exagerada dá ênfase no ter como mais importante do que ser.

Surgem estudos na tentativa de abandonar este reducionismo cartesiano-newtoneano para uma abordagem sistêmica nos meios acadêmicos com estudos de profissionais de diversas áreas, provocando uma transposição de uma paradigma para outro menos conservador, com novas concepções e pressupostos onde considera o homem com uma visão holística e como um ser integral, com mente, razão, emoção e espírito convivendo harmoniosamente com seus valores, crenças, atitudes e aprendizagens.

\subsection{PARADIGMAS TRADICIONAIS}

No paradigma tradicional, como foi vivenciado no inicio do século passado, o aprendizado nas escolas de todo país era caracterizado pelo processo científico newtoniano-cartesiano. Até o espaço de tempo em que as ciências começam a despertar para um novo enfoque que seria a divisão de tarefas entre os setores industriais que necessitavam de mão de obra. A ruptura de um paradigma decorre da existência de um conjunto de problemas, que os pressupostos vigentes na ciência não conseguem solucionar. (BEHRENS, 1999a p. 31).

A humanidade encontra-se diante da uma importante encruzilhada de sua história: A necessidade de renovação de paradigmas. Já é tempo de proteger o mundo e de avançar com novas ideias no que diz respeito à educação e a natureza e o social. Para revalorização da consciência como aspecto-chave de nossas relações com a natureza e desta com o social, é outro dos aspectos essenciais coincidentes entre a nova ciência e a cosmo visão. (PRADO, 2000).

No paradigma tradicional, o professor se ocupava em passar no quando negro, as lições para que os alunos decorassem para fazer as provas. Sua forma de ensinar era repetitiva e apresentava em sala de aula assuntos que já haviam sido estudados. Era rigoroso na disciplina em sala e não admitia questionamentos. Os alunos, por sua vez não desfaziam suas dúvidas e por muitas vezes eram reprovados por incapacidade de perguntar. Pois não arriscavam a perguntar e ficariam sem a resposta, muitas vezes, pois o professor sabia o que havia nos livros. Não havia pesquisa do professor sobre o assunto ensinado. 0 aluno era um indivíduo único e isolado. A metodologia era baseada na repetição. As formulas para o ensino já vinham prontas para o professor. Ele apenas ilustrava o quadro negro para os alunos copiarem. 0 professor era a autoridade e mesmo os alunos não procuravam fazer o diferente. Aceitavam essa condição. A Escola era de meninos e meninas separadamente. Na sociedade deveriam ocupar lugares separados evidentemente.

\subsection{PARADIGMAS ESCOLA NOVISTA}

Essa escola foi introduzida no Brasil por intermédio de Anísio Teixeira. Este foi orientado pelos pensadores, Dewey, Montessori, Piaget por volta de 1930. 0 pensamento da escola novista não durou muito, pois foi logo derrubada pelo tecnicismo.

A Escola Nova trazia uma nova maneira de pensar sobre o ser humano. A escola nessa abordagem propunha pensar no ser humano e nos sentimentos para aprender. 0 professor passa a ser um facilitador da aprendizagem e o aluno torna-se a figura central desse processo. 0 aluno como sujeito ativo, aprende pela descoberta. Com liberdade para aprender participa das experiências de aprendizagem com iniciativa própria. A metodologia no paradigma da escola novista centra-se nas unidades de experiências que o professor vai elaborar junto com os alunos para buscar aprendizagem. (BEHRENS, 1999b p.49)

\subsection{PARADIGMA TECNICISTA}

A partir dos anos 70 o mundo começou a descobrir que o ensino nas escolas e nas universidades poderia acontecer de forma fragmentada, Isso é, separando as disciplinas para que se formassem técnicos que seria a mão de obra especializada que as indústrias necessitavam no momento. Essa visão de mundo 
caracterizou os espaços de forma a não se permitir a junção das partes, o que dividia o mundo em pedaços que não se completavam.

O mundo com uma visão fragmentada passou a ter a educação fragmentada também e já que os jovens são preparados nas escolas para ocuparem cargos governamentais e profissionais particulares e devem dar conta de suprir as necessidades do mercado de trabalho, as metodologias pedagógicas criadas, nas escolas, serviam para manter a sociedade em funcionamento constante. Na realidade, essa nova concepção apregoa um universo não linear, composto por sistemas desorientados e fora do equilíbrio. Esse processo de desequilíbrio gera a instabilidade e a derrubada da organização levando a uma nova ordem. (BEHRENS, 1999c p. 35).

\subsection{PENSAMENTO SISTÊMICO}

O grande impacto do pensamento sistêmico foi que as propriedades das partes podem ser entendidas a partir da organização do todo. Essa visão apresenta-se como o pensamento analítico que é uma forma de pensamento com objetivo de explicar as coisas através da decomposição em partes mais simples, que são mais facilmente explicadas ou solucionadas, e uma vez entendidas tornam possível o entendimento do todo. O comportamento do todo é assim explicado pelo comportamento das partes. 0 pensamento sistêmico é uma nova forma de abordagem que compreende o desenvolvimento humano sobre a perspectiva da complexidade, para percebê-lo, a abordagem sistêmica lança seu olhar não somente para o indivíduo isoladamente, considera também seu contexto e as relações aí estabelecidas. No desenrrolar desse pensamento nasceu o paradigma emergente holístico. Esse paradigma levou ao mundo uma nova visão para a educação e para a prática pedagógica. 0 professor na abordagem holística tem um papel fundamental na superação do paradigma da fragmentação para a produção do conhecimento. Para Behrens,

Com uma visão sistêmica ou holística os docentes precisam instigar seus alunos para a recuperação de valores perdidos na sociedade moderna, buscando a justiça plena e ampla para todas as camadas sociais e provocando a formação de valores imprescindíveis como a paz, a harmonia, a soliedariedade, a igualdade e principelmente a honestidade. (BEHRENS, 1999. P.67)

O aluno já nessa abordagem holística representa-se completo. A criatividade e seu talento são reconhecidos. Trabalhando com o professor com uma metodologia inovadora ele se sente mais capaz. Tem suas inteligências múltiplas reconhecidas também e assim se torna um ser humano mais feliz. A avaliação no paradigma holístico percebe o aluno como uma pessoa que tem seus valores individuais, mas tem seu valor dentro do grupo onde ele está inserido. Nessa avaliação o erro pode ser um caminho permitindo que o aluno aprenda com seu próprio erro.

\subsection{PARADIGMA DA COMPLEXIDADE}

O paradigma da complexidade solicita que levemos ao jovem estudante universitário uma verdadeira reforma do pensamento, semelhante à produzida no passado pelo paradigma tecnicista que se impôs às reformas trazendo técnicas que transformaram as ideias. Mas essa nova abordagem (complexidade) e compreensão do mundo, de um mundo que se "autoproduz", confere também um novo sentido à ação humana; trata-se de fazer nossas apostas, o que vale dizer que com a complexidade ganhamos a liberdade de pensar e agir. Segundo Morin, (2002),

0 poder imperativo de paradigmas e modelos explicativos associa-se o determinismo de convicções e crenças, que, quando reinam em uma sociedade, impõem a todos e a todos a cada um a força proibitiva do tabu. As doutrinas e ideologias dominantes dispõem igualmente, da força imperativa que traz a evidência aos convencidos da força coercitiva que suscita o medo inibidor nos outros. (MORIN, 2002. P.27)

complexidade reapareceu a partir da cibernética e da teoria da informação, com ele as ciências voltam a se unir para viabilizar uma compreensão da realidade social, a idéia é de autonomia em reação a padronização de comportamento, por que atrás de toda ordem existe a desordem e a incerteza numa relação dialética, uma cooperando com a outra e ameaçando também. (SALGADO, 2011). Com o advento da Sociedade do Conhecimento e da revolução tecnológica aparece o paradigma inovador onde também se denomina como holístico (Cardoso,1995b) e sistêmico (Capra,1996b) com outras multiplicidades de 
denominações e com diversas abordagens. Este paradigma busca a natureza do aprendizado em vez de focar em metodologias de ensino, pois entende-se o aprendizado como um processo vencido passo a passo, integrando novas informações em nosso cérebro com o domínio de novas habilidades. (FERGURSON, 1992).

Entre os pressupostos do novo paradigma, a ênfase no aprender a aprender, prestar atenção, fazer boas perguntas, ter acesso a informação, sabendo que o que se sabe hoje pode mudar, novos conhecimentos serão adquiridos com uma estrutura igualitária, onde aluno e professor são pessoas autônomas não limitando o indivíduo pela sua idade, sua experiência anterior passa a ser parte do contexto para o seu aprendizado, preocupando-se com o ambiente deste aprendizado, encorajando a influência da comunidade neste processo, onde a educação dura para toda a vida e não somente no que tange a escola, conforme poderemos analisar no quadro abaixo.

Quadro Sinóptico do Paradigma Holístico

\begin{tabular}{|c|l|}
\hline \multirow{2}{*}{ Aluno } & $\begin{array}{l}\text { Envolvido no processo } \\
\text { Sujeito produtor de seu } \\
\text { próprio conhecimento }\end{array}$ \\
\hline Professor & Reflexivo, instiga o aluno a reconhecer a realidade e refletir sobre ela \\
\hline \multirow{3}{*}{ Metodologia } & $\begin{array}{l}\text { Aliança, teia com visão sistêmica, } \\
\text { Abordagem progressista } \\
\text { Ensino com pesquisa } \\
\text { Interdisciplinaridade } \\
\text { Foco no processo } \\
\text { Fvaliação } \\
\text { Forma cidadão }\end{array}$ \\
\hline \multirow{2}{*}{ Escola } & $\begin{array}{l}\text { Visa o processo } \\
\text { Produção do conhecimento com autonomia } \\
\text { Criatividade e criticidade }\end{array}$ \\
\hline & $\begin{array}{l}\text { Estimula a análise } \\
\text { Visão do todo, } \\
\text { Valoriza a reflexão a ação a curiosidade, Compor e recompor dados }\end{array}$ \\
\hline
\end{tabular}
Fonte: Elaborado pela autora, 2012

Portanto, urge que as universidades mudem suas abordagens através da prática pedagógica para um ensino de qualidade que atenda às demandas da sociedade atual. Conforme Demo (1996) a universidade "[...] deve tomar temas e aprofundá-los, exercitar aplicações do conhecimento, ensaiar deduções e induções, elaborar criativamente, argumentar com propriedade, pesquisar sistematicamente".

\section{METODOLOGIA}

O processo metodológico adotado para este estudo segue uma abordagem qualitativa e como estratégia a pesquisa-ação, que segundo Tripp (2005a) na área educacional é uma tática para o desenvolvimento de professores e pesquisadores de modo que eles possam utilizar suas pesquisas para aprimorar seu ensino e, em decorrência, o aprendizado de seus alunos. "Todos nós aprendemos com a experiência, mas podemos também registrar o que aprendemos a fim de esclarecê-lo, disseminá-lo entre os colegas e acrescentá-lo ao estoque de conhecimento profissional sobre a docência." (TRIPP, 2005b). Desse modo a pesquisa-ação demonstra-se interativa e reflexiva na sua prática profissional com a finalidade de interpretar sua realidade e intervir nela.

A investigação foi desenvolvida através da interação dos participantes mestrandos, doutorandos e professores que cursavam a disciplina Paradigmas Educacionais e Formação de Professores - PEFOP da linha de pesquisa Teoria e Prática Pedagógica na Formação de Professores, do Programa de Pós Graduação em Educação da Pontifícia Universidade Católica do Paraná, no primeiro semestre do ano de 2012 durante onze encontros semanais mediados por um professor doutor coordenador da pesquisa. Os participantes estavam envolvidos no processo investigativo de variadas áreas de conhecimento onde atuam ou gostariam de atuar como docentes universitários. 
O estudo foi desenvolvido na Pontifícia Universidade Católica do Paraná - PUCPR, por meio de um processo investigativo que propiciou doutorandos, mestrandos e professores que cursavam a disciplina Paradigmas Educacionais na Prática Pedagógica do Programa de Pós-Graduação em Educação. A disciplina apresentada tinha em sua ementa os paradigmas educacionais conservadores e inovadores, o paradigma cartesiano e as abordagens conservadoras que visam à reprodução do conhecimento. A proposição do paradigma da complexidade na ação docente. As competências elencadas eram: analisar reflexivamente os paradigmas contemporâneos e a sua influência na educação, investigar na rede de informação sobre a temática proposta, discutir criticamente o papel do professor e sua metodologia na atuação docente entre outras.

O processo investigativo deu-se através de aula teórica expositiva, abordagens teóricas, leituras que foram recomendadas e reflexões individuais e coletivas. Foram elaborados quadros sinópticos analisando a escola, aluno, professor, metodologia e a avaliação, tanto individualmente quanto coletivamente nas abordagens tradicional, escolanovista, tecnicista, holística, progressista e ensino com pesquisa. Foi apresentada uma proposta através de portfólio durante os encontros semanais. Ao final da disciplina foram elaborados artigos científicos sendo uma produção individual e outra produção coletiva.

Dentro da proposta do portfólio a avaliação processual deu-se através da presença em sala de aula, investigação na rede de informação sobre a temática proposta, leituras e anotações realizadas, participação efetiva nas discussões, leitura crítica e produção de textos. Desta forma Durante as atividades individuais e coletivas com as discussões em sala de aula, pude perceber que muitas abordagens que realizava na minha prática pedagógica, quanto coordenadora de curso a distância, preocupada com a aprendizagem e a autonomia do aluno e a construção do seu conhecimento coletivo, eram pertinentes à uma prática inovadora dentro do paradigma da complexidade com uma visão holística do professoraluno.

Com as discussões em aula percebi que é possível ser um professor-reflexivo da sua prática pedagógica no ensino a distância, onde ser professor é ser mediador e facilitador. Como coordenadora de curso, compreendi que devo comprometer-me com a formação continuada dos docentes que atuam no ensino a distância, sob minha coordenação, onde meu papel não é somente com a escola e com a metodologia em sí, mas com a sociedade no seu sentido mais amplo. 0 aprender a aprender supõe que alunos e professores sejam criativos e inovadores e construam o seu conhecimento colaborativamente.

Como aluna tive enorme satisfação em frequentar e compartilhar com os outros colegas o conhecimento novo através das aulas da disciplina: Paradigmas Educacionais na Prática Pedagógica, uma vez que essa pesquisa vai de encontro com minhas ideias, e pretendo aproveitar os conceitos e opiniões, como base do meu projeto de Mestrado. Os conceitos inovadores ampliaram a minha visão pedagógica da educação e pretendo trabalhar para levar esse conhecimento aos meus educandos.

\section{CONSIDERAÇÕES FINAIS}

As mudanças somente acontecem quando aceitamos os desafios que elas se propõem. Primeiramente temos de acreditar que elas podem acontecer, comprometermos a deixar a zona de conforto de aulas expositivas e elaboradas, com uma prática tradicional da reprodução do conhecimento para outra forma de abordagem é desafiador. Devemos buscar envolvimento dos alunos e professores, através de projetos e trabalhos sistematizados, com atividades diferenciadas, dialogadas e consensuais, onde o professormediador e facilitador instiga seus alunos para a aprendizagem. Esta é a proposta do paradigma emergente, com uma visão holística para o ensino superior, onde aluno e professor são aliados na construção deste conhecimento em rede, pois todos estão interligados. A aprendizagem além de adquirir habilidades e conhecimentos é mais do que acumular conhecimento ou saber ter, é colocar-se no caminho do saber ser, onde o caminho é tão ou mais importante, do que a chegada e onde o aprendizado é para a vida toda.

\section{REFERENCIAS}

[1] Aguiar, Afrânio Carvalho; Ferreira, José Rincón. Educação corporativa e educação a distância. Org. Eleonora Jorge Ricardo. Rio de Janeiro : Qualitymark, 2005.

[2] Behrens, Marilda Aparecida, O paradigma Emergente e a Prática Pedagógica. Ed. Champagnat, Curitiba -PR, 1999. 
[3] Paradigmas da complexidade. Metodologia de projetos, Contratos didáticos e Portfólios. Ed. Vozes. Petrópolis, RJ. 2008. O Paradigma Emergente e a Prática Pedagógica. Petrópolis. RJ: 5 ed.Vozes,2011.

[5] Cardoso, Clodoaldo Meneguello. A Canção da Inteireza. Uma visão holística da educação. São Paulo. Summus,1995.

[6] Demo, Pedro. Educar pela pesquisa. Campinas: Autores Associados,1996

[7] Ferguson, Marylin. Voar e ver: Novos Caminhos para o aprendizado. In: A conspiração aquariana. Rio de Janeiro:Record.1992.

[8] Kenski, Vani Moreira. Educação e tecnologias: O novo ritmo da informação. 7 ed. Campinas : Papirus. 2010.

[9] Khun, Thomas. A estrutura das revoluções científicas. 4 ed. São Paulo:Pespectiva,1996

[10] Morin, Edgar. Os sete saberes necessários à Educação do Futuro. Ed. 5 São Paulo, Cortez, 2002.

[11] Prado, Francisco Gutiérrez Cruz, Ecopedagogia e Cidadania Planetária. 2aㅗ ed. Ed Cortez, 2000.

[12] Salgado, Maria da Conceição Spinola. Artigo. Paradigma da Complexidade e Teoria das organizações: uma reflexião epistemilógica. 2011.Disponível em: http://complexidade.ning.com/profiles/blogs/paradigma-dacomplexidade-e-teoria-das-organiza-es-uma-reflex- Acesso: 21 jun 2012.

[13] Tripp, D. Critical incidents in teaching: the development of professional judgement. Londres e Nova York: Routledge, 1993. 


\section{Capítulo 15}

\section{A provinha Brasil: Instrumento que diagnostica $e$ promove a aprendizagem ou limita e aprisiona a prática docente?}

\section{Celi Traude Kellermann}

Eliane Greice Davanço Nogueira

Ana Paula Gaspar Melim

Resumo: No presente artigo apresentamos algumas reflexões acerca do Sistema de Avaliação da Educação Básica (SAEB), especialmente sobre a Provinha Brasil. A Provinha Brasil é aplicada no $2^{\circ}$ ano do Ensino Fundamental e foi criada com o objetivo de avaliar as habilidades relativas à alfabetização e ao letramento em Língua Portuguesa e Matemática. É elaborada e distribuída pelo Instituto Nacional de Estudos e Pesquisas Educacionais Anísio Teixeira (INEP) a todos os estados e municípios da União e está articulada ao Plano Nacional de Educação (PNE), mais especificamente às metas que se relacionam a alfabetizar todas as crianças até os oito anos de idade, como o Pacto Nacional pela Alfabetização na Idade Certa - PNAIC. Em busca de melhorar o nível de educação, o governo federal fez grandes investimentos em formação continuada. No entanto, os resultados aferidos pelas avaliações de larga escala continuam se mostrando insatisfatórios. Nessa perspectiva, esse trabalho procura contextualizar a alfabetização no Brasil e a forma como vem sendo avaliada, evidenciando os dilemas e as preocupações relacionados aos índices nacionais que afetam diretamente a prática docente, referendando a Provinha Brasil e a sua influência na prática do cotidiano do professor alfabetizador. Para perceber esse efeito, o instrumento adotado nessa investigação é a narrativa (auto) biográfica, transcritas a partir de uma entrevista, tendo como sujeito uma professora de uma escola da Rede Estadual de Ensino de Mato Grosso do Sul, do município de Campo Grande, que vivencia a prática alfabetizadora e as implicações da Provinha Brasil em sala de aula. Conclui-se que a necessidade da escola em alcançar índices e metas tem levado as redes de ensino a preocupar-se mais em alcançar índices do que com o desenvolvimento das habilidades dos alunos avaliadas nas Provinha Brasil.

Palavras - Chave: Avaliação. Provinha Brasil. Alfabetização. 


\section{INTRODUÇÃO}

A partir da década de 1990 efetivou-se a universalização do ensino e a reconceituação da educação brasileira sob a influência de políticas globalizadas de programas educacionais, de caráter neoliberal e avanços tecnológicos.

A implementação destes programas está ancorada nas orientações da Conferência Mundial de Educação para Todos, que tem como base o dever do Estado e da Família proporcionar o direito à educação com igualdade de acesso e permanência na escola, com padrão de qualidade e direito de cidadania, o qual visa o incentivo e apoio da sociedade em proporcionar essa educação para todos.

O direito de matrícula na escola e o grande investimento na educação por meio de ações derivadas de políticas públicas não trouxeram os resultados esperados quanto à aprendizagem dos estudantes com alta taxa de distorção idade-série, o que despertou reflexões e questionamentos sobre os direitos individuais de aprendizado de competências cognitivas básicas e gerais.

Para atender estas necessidades, o governo implantou algumas políticas de acompanhamento, dentre as quais a Prova Brasil, SAEB e a Provinha Brasil, que são utilizados como instrumentos para avaliar e diagnosticar a realidade de cada escola e possibilitar a contribuição de propostas para implementar medidas que superem as dificuldades encontradas na aprendizagem dos estudantes.

A Provinha Brasil é aplicada no $2^{-}$ano do Ensino Fundamental, utilizada para aferir resultados que permitem conhecer como foi o avanço das crianças na aprendizagem, "em termos de habilidades de leitura e de matemática" e possibilita um diagnóstico que poderá orientar professores e gestores na busca de melhoria da qualidade de ensino.

Nesta perspectiva, este artigo procura trazer uma breve contextualização da alfabetização no Brasil e a influência da Provinha Brasil na prática avaliativa no cotidiano do professor, por meio da análise da narrativa de uma professora, que atua nas séries dos anos iniciais.

\section{ALFABETIZAÇÃO NO BRASIL}

A alfabetização escolar, segundo Mortatti (2010), é um processo complexo e de muitas facetas que envolve ações políticas dentro do Estado de direito do cidadão, numa sociedade letrada, a qual tem a necessidade de levar a alfabetização a todos e para isso, precisa implementar ações eficazes por meio de políticas públicas.

Decorrente da complexidade e multifacetação do processo escolar envolvido, a história da alfabetização no Brasil se caracteriza, portanto, como um movimento também complexo, marcado pela recorrência discursiva da mudança, indicativa da tensão constante entre permanências e rupturas, diretamente relacionadas a disputas pela hegemonia de projetos políticos e educacionais e de um sentido moderno para a alfabetização..(MORTATTI, (2010, p. 330)

Mediante os estudos de Mortatti (2010), sabemos que os anos de 1990, no Brasil a responsabilidade de indução, articulação e regulação configurou-se a responsabilidade de aplicação ao setor público não estatal e para o setor privado a articulação dos processos de descentralização e centralização no surgimento de distintos sistemas educacionais independentes.

Como resultante dessa reforma do Estado brasileiro, surgem novas formas de regulação entre o público e o privado, o público estatal e o não estatal, possibilitando uma nova parceria: Estado e subsetores públicos. Tal configuração, evidenciou compromissos e metas relacionados à alfabetização: 
[...] declaração do "Ano Internacional da Alfabetização" (1990); Declaração de Jomtien (1990); Declaração de Dakar - Educação Para Todos (2000); Objetivos de Desenvolvimento do Milênio (ODM) (2000); Alfabetização para o Empoderamento (LIFE) (2005); e Década das Nações Unidas para a Alfabetização (2003-2012). E, em âmbito nacional, alinhada a essas diretrizes, a mais recente e emblemática iniciativa governamental é o PNAIC - Pacto Nacional pela Alfabetização na Idade Certa.E em correspondência direta com essas iniciativas, tem-se a implementação de testes padronizados de avaliação de estudantes em larga escala, de abrangência internacional, como o PISA, ou nacional, como Prova Brasil, SAEB e Provinha Brasil. (MORTATTI, OLIVEIRA, PASQUIM, 2014, p.12).

Para responder as demandas políticas, sociais e educacionais, segundo Mortatti (2010), o sistema de ensino brasileiro procurou elaborar projetos marcados por tensões de rupturas e disputas políticas em cada período histórico, com o enfoque em métodos e estratégias de ensinar.

No Brasil os métodos sempre foram utilizados de forma mista, Frade (2007), aponta que, a partir da década de 1930, as influências dos métodos intuitivos e ativo interferiram no trabalho do professor, independentemente dos métodos que fossem utilizados, como na escolha de textos e jogos de alfabetização.

Destacam a adoção dos modelos teóricos construtivista, interacionismo linguístico e letramento. Em fins da década de 1990 o conceito letramento provocou alterações paradigmáticas, estabelecendo uma escrita e leitura contextualizada dentro das esferas sócio-culturais, viabilizando a compreensão por parte da criança.

Em busca da melhoria da qualidade de ensino, foram implementadas políticas de acompanhamento que utilizam instrumentos de avaliação e afetam o trabalho do professor. Em tal contexto, foi criada a Provinha Brasil em 2007, como complemento de avaliação da educação básica com o objetivo de avaliar o desempenho dos estudantes no processo de alfabetização para diagnosticar, intervir e criar instrumentos pedagógicos que permitam fazer intervenções corretivas preventivamente para superar as dificuldades em que os alunos se encontram, como ainda, estabelecer metas e políticas para melhorar a qualidade de ensino e reduzir as desigualdades.

A partir da década de 1980 houve um questionamento sistemático quanto à eficácia da alfabetização, uma vez que o maior fracasso escolar era encontrado na escola pública, onde se concentrava a maior parte da população pobre. Desde então, segundo Mortatti (2010, p.332), foram adotados três modelos teóricos os quais foram denominados construtivismo, interacionismo linguístico e letramento, sendo que destes o construtivismo foi hegemônico, pela sua oficialização em termos de políticas públicas para a alfabetização. Mais recentemente, ao fim da década de 1990, o conceito de letramento trouxe alterações paradigmáticas, com a proposta direcionada para a escrita e a leitura contextualizada dentro das condições socioculturais, a fim de possibilitar uma maior compreensão por parte do aluno. Frade $(2007$, p. 32) expõe que se quer beneficiar, com isso, a cultura escrita como um todo, dando elementos para que novos usos sejam possíveis. Assim, a escola passa a "[...] tratar a língua como objeto de reflexão e como objeto cultural, isto, às vezes, implica em metodologias diferentes".

Por esse prisma, Smith (1999) enfatiza que há muitos métodos de ensino de leitura e ainda uma quantidade maior de estudos e comparações entre estes, que demonstram que nenhum desses métodos é um fracasso total, uma vez que com todas as teorias se obtêm algum tipo de sucesso, ainda que nenhum método tenha tido sucesso com todas as crianças. Para o autor, durante séculos as crianças têm aprendido a ler, mesmo diante das maiores adversidades.

Dentre as diferentes metodologias para a aprendizagem e compreensão do sistema de escrita, quem determina o tipo de ensino utilizado para promover a alfabetização é a sociedade, pois se percebe que o professor é quem, por fim, toma as decisões de organizar o ambiente, definir capacidades, escolher materiais e procedimentos de ensino e avaliação, sempre dentro de um contexto maior de organização de ensino. No entendimento de Frade (2007, p. 36), não é viável utilizar apenas um método, em sua forma "pura" na alfabetização, pois nenhum deles, sozinho é suficiente para atender a todas as especificidades de conteúdos e apreensão da mesma.

Sob outro foco, Soares (2003), aponta a divisão de ciclos e a progressão continuada (não reprovação), como um agravante na perda da especificidade da alfabetização. Além do mais, segundo a autora, a partir da década de 1980, juntamente com a difusão do letramento, emergiu um pensamento que levou à 
depreciação dos métodos e a ignorar-se o uso de técnicas para a aquisição da escrita. A autora afirma que, independente da forma, com que se alfabetiza para aprender a ler e a escrever é preciso orientar os aprendizes a codificar e decodificar, ou seja, fazer a relação entre fonemas e grafemas. Portanto, seria falsa a ideia de que a criança aprenderia somente por meio do convívio com os textos, sem a interferência do professor e uma orientação sistemática e progressiva. Em sua análise afirma, ainda, que antes havia um método, mas sem teoria. Depois se passou a ter uma teoria sem método. Para Soares (2003), é preciso, no entanto, alcançar as duas dimensões: uma teoria que produza um método.

De maneira similar, Morais (2006), apresenta critérios de que é preciso olhar além dos métodos e metodologias, pois para ele não existem "métodos milagrosos" que possam garantir o sucesso por si só. E que dificilmente uma teoria embasada no individual, pode dar certo ao ser aplicada no coletivo, no caso, a escola.

0 autor destaca que a formação inicial e continuada dos professores nas últimas décadas, foi constituída pela trajetória percorrida pelo aprendiz para apreender o sistema alfabético, em vez da forma de como o professor deveria encaminhar o aprendiz a esta aquisição. Constata, por meio de suas pesquisas, que há "[...] certa falta de clareza, entre estudiosos e docentes, quanto à necessidade de ensinar, sistematicamente, as propriedades da escrita e suas convenções" (MORAIS, 2006, p. 6).

Nesta perspectiva, destacamos a importância de reconhecer a contextualização da alfabetização no Brasil para analisar a influência da Provinha Brasil na prática avaliativa.

\section{CONTEXTUALIZANDO A PROVINHA BRASIL}

Na tentativa de superar as deficiências na educação, a proposição das avaliações externas, dentre elas a Provinha Brasil, apresenta-se no cenário educacional como uma iniciativa para melhorar a qualidade na educação.

A Constituição Federal 1988 prevê a educação como direito de todos com a garantia de padrão de qualidade. Em busca de superar o quadro de alunos excludentes, ou seja, o baixo rendimento escolar, a educação está à procura de propostas mais extensivas que visam introduzir dimensões sociais e culturais, com formas de conhecer, ensinar e aprender os conhecimentos esperados.

O Governo Federal tem apresentado varias iniciativas para melhorar a qualidade na educação, entre elas a ampliação do ensino fundamental de 8 para 9 anos, com a entrada da etapa do ensino obrigatório aos 6 anos, o Plano de Metas Compromisso Todos pela Educação e o Pacto Nacional pela Alfabetização na Idade Certa (PNAIC), que visa a alfabetização da criança até os oito anos de idade com qualidade e para todos, e avaliações periódicas de desempenho dos alunos.

Dentre elas, o SAEB e a Prova Brasil que trazem resultados indicando o baixo desempenho leitor dos estudantes no final do $4^{\mathrm{a}}$ ano do ensino fundamental. Na procura de superar essas e outras deficiências, buscou-se avaliar o desempenho dos alunos no período final da alfabetização.

E é nesse bojo que a Provinha Brasil é criada, numa tentativa de buscar as origens do desempenho, por meio do diagnóstico do processo de alfabetização dos alunos no início e ao final do segundo ano, para que, conhecendo as dificuldades apresentadas pelos alunos, pudessem ser propostas ações de intervenção pedagógica que dessem conta de corrigir esses problemas e promover uma educação igualitária. De acordo com a Portaria Normativa no 10 :

Art. $2^{\circ}$ A Avaliação de Alfabetização "Provinha Brasil" tem por objetivo:

a) avaliar o nível de alfabetização dos educandos nos anos iniciais do ensino fundamental;

b) oferecer às redes de ensino um resultado da qualidade do ensino, prevenindo o diagnóstico tardio das dificuldades de aprendizagem; e 
c) concorrer para a melhoria da qualidade de ensino e redução das desigualdades, em consonância com as metas e políticas estabelecidas pelas diretrizes da educação nacional. (BRASIL, 2007, n.p)

Segundo os documentos oficiais, a Provinha Brasil visa à participação de todos os envolvidos no processo educativo, sejam alunos, professores ou gestores. Desta forma, a sua aplicação pretende auxiliar as redes de ensino a obter informações sobre os processos de alfabetização e letramento e das habilidades iniciais em Língua Portuguesa e Matemática, o que permitiria uma reorganização da prática pedagógica nessas áreas de conhecimento.

Conforme os autores, não existe uma política adequada que dê suporte à heterogeneidade de conhecimento dos alunos, que ensine considerando os diversos ritmos de aprendizagem e que assegure, nas escolas públicas, o direito de aprender.

Nesse sentido, destacamos Morais et al (2009) que considera que é preciso avaliar para responder à necessidade de delimitar metas que deem mais clareza ao currículo e ao que se espera das crianças, em questões de aprendizagem. Entendem, ainda, que essas avaliações podem servir para subsidiar uma política de formação de professores e seleção de recursos didáticos, qualificando o ensino oferecido nos primeiros anos do Ensino Fundamental e proporcionando um diagnóstico da aprendizagem do aluno, que possibilite ao professor buscar formas de intervir e superar as dificuldades apresentadas no processo de alfabetização. Segundo a crítica dos autores, a devolutiva dos resultados ao professor pode confundi-lo, pois é feita por escala e não por habilidades avaliadas. Enfatizam, nesse sentido, que é importante o professor receber "[...] um diagnóstico de cada aluno em cada uma das habilidades avaliadas", (MORAIS et al, 2009, p. 309), pois quanto mais objetiva a informação, tanto maior será a precisão da intervenção do professor em ajudar a criança a superar suas dificuldades e desenvolver as habilidades que ainda não domina.

No entendimento de Esteban (2012, p. 582), a avaliação em larga escala não leva em conta a linguagem e a experiência que faz parte da vida cultural do estudante, é descontextualizada, sustenta a classificação dos estudantes e reduz a educação ao campo técnico-pedagógico, sem conexão com a vida social e cultural existente no dia a dia da escola.

De forma análoga, ressalta o contrassenso que existe entre o Plano Nacional de Educação (PNE) e a Provinha Brasil, com a meta de "Alfabetizar todas as crianças até, no máximo, os oito anos de idade" (ESTEBAN, 2012, p.581), uma vez que a política educacional em questão, ao mesmo tempo em que reforça a democratização do ensino, ativa a inclusão/exclusão escolar, por meio da idealização de parâmetros de aprendizagem homogêneos para todos. Outra incoerência apontada pela autora é o reconhecimento, por parte das instâncias oficiais, da diferença de aprendizagens, porém, na apuração dos resultados, essa diferença é tida como insuficiência: "Essa relação prevê resultados dissonantes que fazem que alguns não consigam se integrar ao todos." (ESTEBAN, 2012, p.582, grifado pelo autor).

A consolidação do exame nacional para crianças articula-se à possibilidade de sua manutenção na escola em um contexto de inclusão degradada (Martins, 1997), em que a ideia de todos está marcada por um variado conjunto de exclusões, necessárias à normalização, e protegido por um impreciso conceito de inclusão. (ESTEBAN, 2012, p.582)

Quanto aos resultados da análise dos desempenhos dos estudantes, Morais (2009) evidencia a preocupação de não culpabilizar o professor, em conformidade com o que defende Esteban (2012, p.587), quando afirma que é necessário que a formação aconteça a partir dos questionamentos e dificuldades encontradas na própria prática do professor.

Nesse sentido, Esteban (2012) menciona as análises de Collares e Moyses (1996) e Patto(1991), para quem as justificativas sobre desempenhos insuficientes nas avaliações em larga escala se apoiam em concepções de educação que responsabilizam o sujeito na escola pelo fracasso, e não apontam o "fracasso de um projeto de escola" (ESTEBAN, 2012, p.581-582), o que acaba induzindo o trabalho pedagógico ao treinamento constante para a realização de exames padronizados. Para a autora, portanto, os exames padronizados enfraquecem a autonomia do professor "[...] pelos mecanismos de controle ao qual se vincula, inclusive no que se refere ao planejamento cotidiano da prática pedagógica." (ESTEBAN 2012, p.586) 
Em tal contexto, Smith (1999, p. 139-140) expõe que a reiterada busca por testes e avaliações que apontem responsáveis pelo insucesso escolar pode provocar tensão e medo do fracasso, tanto no docente quanto no aprendiz.

Em seus estudos mais recentes, Morais (2012) declara que suas pesquisas tem demonstrado a insegurança dos professores quanto à sua prática alfabetizadora e à avaliação do progresso dos alunos. Cita alguns casos em que professores e escolas chegaram a adotar medidas para com os estudantes que não conseguiram atingir as metas, como reprová-los por excesso de faltas ou recolocá-los para assistir as aulas da turma do ano anterior.

Diante desse quadro, reitera-se a necessidade de assegurar a formação continuada aos professores, a melhoria das condições de trabalho, uma definição objetiva de bases curriculares e políticas públicas que garantam o respeito à diversidade de ritmos de aprendizados e condições adequadas ao exercício da docência. Sugere, portanto, que o tratamento dos dados não seja feito em escala de níveis, mas que sejam identificadas as habilidades que cada aluno já desenvolveu e quais ainda precisa de ajuda para desenvolver. Recomenda que professores e gestores "[...] possam dispor de mecanismos efetivos para planejar e realizar um ensino que considere as necessidades dos aprendizes." (MORAIS, 2012, p.569)

Nessa mesma perspectiva, Kusiak (2012) aponta que o retorno do resultado das avaliações às escolas não é sistemático e a análise é um pouco vaga, sendo que muitas vezes os gestores e professores não conseguem entender e analisar o processo por falta de mais dados. Essas circunstâncias e levam as escolas a realizarem uma avaliação superficial dos resultados, observando apenas quantos estudantes atingiram (ou não) um determinado "nível", medido por meio do número de respostas corretas, segundo os critérios determinados como adequados pelo INEP.

O caminho percorrido entre buscar políticas adequadas aos parâmetros e normas internacionais, neste caso a Provinha Brasil, e o impacto que elas produzem no chão da escola e no trabalho cotidiano do professor alfabetizador, gera sentimentos conflitantes, dúvidas e questionamentos, em última análise, destacamos que a avaliação não deveria figurar somente como uma radiografia de uma dada realidade negativa, mas ao contrário é preciso entender quais percursos envolvem os professores, alunos e a proposição da provinha, tomando-a como uma referência norteadora da prática docente.

\section{A PROVINHA BRASIL NA ESCOLA}

Entendemos que a escola é o espaço central da ação educativa, portanto é para ela que devem voltar às atenções, o apoio técnico pedagógico e os recursos necessários na garantia do direito de aprender. Nesse processo, o saber é construído na ação e, por meio da coleta de novos elementos, é enriquecido e atualizado constantemente.

Canário (1998, p.20) define o professor como um reinventor de práticas, que busca solucionar problemas através da experiência, reverem conceitos, trabalhar em equipe, elaborar propostas e estratégias, "[...] reconfigurando-as de acordo com as especificidades dos contextos e dos públicos". O professor aprende na relação com os alunos, na convivência com o outro e na prática social, construindo assim sentidos sobre si mesmo. Por isso, a articulação entre as situações de trabalho e formação, tanto a inicial como a continuada, deve ocorrer de forma interativa e simultânea, envolvendo alunos, professores, formadores e supervisores.

Nesse sentido, buscamos analisar a aplicação da Provinha Brasil no âmbito escolar, mais especificamente, na visão de uma professora da escola da rede estadual de ensino do Estado de Mato Grosso do Sul.

Perguntamos à professora sobre o propósito da Provinha Brasil, a mesma responde abordando a complexidade da "avaliação".

Eu gosto da Provinha Brasil que nem eu falei, são coisas amplas. A gente vê a amplitude da matéria que a gente está dando, referente ao nosso referencial. [...] fica muito criteriosa no I bimestre. [...] está muito forte pras crianças que estão vindo fracas. [...] o texto está muito grande para o primeiro momento. (P1)

Entende que a avaliação tem por objetivo traçar um Parâmetro Nacional do nível de aprendizagem dos alunos no "país". 
É, através da coordenação da escola, nos foi explicado qual o objetivo da prova, de uma maneira geral, é traçar um Parâmetro Nacional, né, do nível de aprendizagem do país todo. Fazendo equiparação. Imagino... pra poder... Saber se os alunos da região Norte, como eles estão em relação ao Sul, em relação ao Sudeste, centro-oeste. Né, porque é a mesma prova aplicada em diversas regiões e nem todas as regiões tem o mesmo rendimento, né... social... intelectual....(P1)

Na verdade, o diagnóstico realizado por meio da Provinha Brasil objetiva, principalmente, que seus resultados sejam utilizados em favor de intervenções pedagógicas que possam melhorar a qualidade do ensino e não conforme exposto pela professora, "ranqueamento" entre as escolas do País e seus respectivos alunos.

Percebemos, analisando a resposta, que falta atribuir aos professores um protagonismo no processo avaliado, garantido que as informações efetivas e sistematizadas referentes a Provinha Brasil promova uma reflexão sobre a forma de ensinar e sobre a forma do aluno aprender.

Embora se tenha a impressão de que a avaliação de larga escala, como política pública, foi bem divulgada, explicada e justificada para todos os envolvidos no processo, desde as secretarias de educação, passando pela gestão escolar e chegando até o professor responsável pela sala de aula, aparentemente para alguns desses sujeitos faltaram, de alguma forma, informações e referencias para que o professor possa elaborar seu planejamento pedagógico, estabelecer metas, compor atividades de forma apropriada para trabalhar as especificidades de sua turma.

A esse respeito, destacamos ESTEBAN (2012), quando se refere aos exames estandardizados como limitadores da autonomia docente, o que gera desconfiança no professor sobre sua capacidade em relação à prática pedagógica.

Mais do que um mapeamento do desempenho dos alunos, a provinha Brasil, possibilita reunir elementos para planejar ações que visem o melhor desempenho cognitivo dos alunos em situações mais complexas, porém sabemos que existe um longo caminho a ser percorrido na direção deste propósito, que rompe com uma visão que se propõe simplesmente a mensurar o rendimento escolar.

Nessa perspectiva Esteban (2012, p.576) preconiza:

A política de avaliação apresenta-se como meio para se alcançar melhor qualidade na educação brasileira, porém se fundamenta na redução de seu sentido e na simplificação nas análises sobre a produção dos resultados escolares. Ao simplificar processos complexos, retira da reflexão e do debate aspectos indispensáveis à ação escolar, aos processos de aprendizagem, aos projetos de ensino e aos posicionamentos dos sujeitos em relação a seus resultados globalmente considerados, não apenas sujeitos hierarquicamente posicionados segundo seus desempenhos. Simultaneamente, sua intenção de neutralidade e objetividade não se realiza, pois a técnica não é suficiente para eliminar a dimensão sociocultural do conhecimento, dos processos de sua socialização e validação ou mesmo das dinâmicas de aprendizagem.

Ao afirmar que o cumprimento de metas e elevação de índices de desempenho não expressam necessariamente uma efetiva ampliação dos conhecimentos pelos estudantes ou uma ruptura com os mecanismos de produção das desigualdades escolares, a autora nos convida a refletir. Isso porque de fato para se garantir uma melhora na qualidade da educação há que se ir além, haja vista que nem sempre uma avaliação é capaz de revelar todo conhecimento do aluno.

\section{CONSIDERAÇ̃̃ES FINAIS}

Na tentativa de responder a necessidade de superar as dificuldades quanto ao baixo nível de alfabetização, percebe-se que os dados fornecidos pelos resultados da Provinha Brasil não são suficientes, MORAIS (et al., 2009), evidencia que os resultados apresentados à escola deveriam ser sobre as habilidades e conhecimentos que os estudantes ainda não conseguem dominar, e não por escalas.

A Provinha Brasil visa em sua proposta, melhorar os índices da educação, contudo não se pode definir a prática docente pela avaliação padronizada, pois estaríamos reduzindo as possibilidades de aprendizagem dos alunos. Para que a Provinha Brasil alcance os objetivos para os quais foi proposto, é importante que os 
resultados sejam analisados e discutidos, com registro e acompanhamento, estabelecimento de metas, busca de soluções e elaboração de estratégias, com a participação dos professores e da equipe técnica e gestora da escola. Conclui-se que a preocupação em alcançar índices e metas não pode figurar como eixo central das discussões em torno dos processos avaliativos, mas ao contrário o eixo deve estar na reflexão do professor sobre sua prática, com um trabalho mais sistematizado e com foco no aprendizado do aluno.

\section{REFERÊNCIAS}

[1] Brasil, Portaria Normativa n. 10 de 24 de abril de 2007. Institui a Avaliação de Alfabetização "Provinha Brasil". Brasilia, 2007. Disponível no site: http://download.inep.gov.br/educacao_basica/provinha_brasil/legislacao/2007/provinha_brasil_portaria_normativa _n10_24_abril_2007.pdf - visualizada em 11/04/2014.

[2] Brasil. Instituto Nacional de Estudos e Pesquisas Educacionais Anísio Teixeira (INEP). Provinha Brasil. Disponível em: http://portal.inep.gov.br/web/provinha-brasil/provinha-brasil Acesso em 10/04/2014

[3] Canário, R. A escola: o lugar onde os professores aprendem. Revista Psicologia da Educação, São Paulo, v.6, n.10, p. 9-27, 1998.

[4] Collares, Cecília; Moysés, Maria Aparecida. Preconceitos no cotidiano escolar: ensino e medicalização. São Paulo, Cortez, 1996.

[5] Esteban, Maria Teresa. Considerações sobre a política de avaliação da alfabetização: pensando a partir do cotidiano escolar. Revista Brasileira de Educação, Rio de Janeiro, v. 17, n. 51, p.573 - Dez 2012, vol.17, no.51, p.573588.

[6] Frade, Isabel C. A. S. Métodos de alfabetização, métodos de ensino e conteúdos da alfabetização: perspectivas históricas e desafios atuais. Educação, Santa Maria, v. 32, n. 01, p. 21-40, 2007. Disponível em: http://cascavel.ufsm.br/revistas/ojs-2.2.2/index.php/reveducacao/article/viewFile/658/469. Acesso: 30/04/2014.

[7] Kusiak, Sandra Mara. Uma análise da prova brasil com enfoque nos processos de Leitura e escrita. In IX Amped Sul - Seminário de Pesquisa em Educação da Região Sul, Caxias do Sul, 2012. Disponível em: http://www.ucs.br/etc/conferencias/index.php/anpedsul/9anpedsul/paper/viewFile/265/106 Acesso em: $10 / 04 / 2014$.

[8] Morais, Artur Gomes de.Políticas de avaliação da alfabetização: discutindo a Provinha Brasil.Revista Brasileira de Educação, Rio de Janeiro, v.17, n.51, p.551-572 , Set/Dez 2012. Disponível em: http://www.scielo.br/scielo.php?script=sci_arttext\&pid=S1413-24782012000300004\&lng=pt\&nrm=iso\&tlng=en. Acesso em: 23/07/2014.

[9] _. Concepções e metodologias de alfabetização: por que é preciso ir além da discussão sobre velhos "métodos"? 2006. Disponível em: http://portal.mec.gov.br/seb/arquivos/pdf/Ensfund/alf_moarisconcpmetodalf.pdf. Acess0 em: 30/04/2014.

[10] _ _ _ Leal, T. F.; Albuquerque, E. B. C.; "Provinha Brasil”: monitoramento da aprendizagem e formulação de políticas educacionais. Revista Brasileira de Políticas e Administração em Educação, Goiânia, v.25, n.2, p.301-320, mai/ago. 2009. Disponível em: http://seer.ufrgs.br/rbpae/article/viewFile/19499/11323 Acesso em: 10/04/2014.

[11] Mortatti, Maria do Rosário Longo. Alfabetização no Brasil: conjecturas sobre as relações entre políticas e seus sujeitos privados. Revista Brasileira de Educação, Rio de Janeiro, v.15, n.44, p. 329-341, 2010. Disponível em: http://www.scielo.br/scielo.php?script=sci_arttext\&pid=S1413-24782010000200009\&lng=pt\&nrm=iso\&tlng=pt Acesso em: 10/04/2014.

[12] Patto, Maria Helena Souza. A produção do fracasso escolar. São Paulo: T.A. Queiroz, 1991.

[13] Smith, Frank. Leitura significativa. 3ed. Porto Alegre: Artes Médicas, 1999.

[14] Soares, Magda. A reinvenção da alfabetização. Parte da palestra proferida na FAE UFMG, em 26/05/2003, na programação "Sexta na Pós". http://www.cereja.org.br/site/_shared/Files/_cer_old/anx/magda_soares_reinvencao.pdf Acesso em 30/05/2014 


\section{Capítulo 16}

O pacto nacional pela alfabetização na idade certa (PNAIC) e a formação continuada do professor alfabetizador

\section{Maria Silvia Bacila}

Resumo: Este estudo discute a formação de professores alfabetizadores de uma rede municipal de ensino da região metropolitana de Curitiba, bem como a participação destes no Pacto Nacional pela Alfabetização na Idade Certa (PNAIC) e os desafios que enfrentam especificamente nas classes alfabetizadoras. A alfabetização ocupa ainda, no século XXI um lugar que guarda tensões, pois muitos professores preferem outros níveis de ensino a enfrentar os desafios de ensinar a ler e a escrever, especialmente na amplitude do letramento. Este estudo investiga as influências da formação do PNAIC e suas determinações nas opções de 27 professores do $1^{\circ}$ ao $3^{\circ}$ ano. Para esta pesquisa buscou-se a contextualização da inserção profissional e o cenário da alfabetização no qual as práticas pedagógicas se manifestam. A abordagem desta pesquisa é de cunho qualitativo (LANKSHEAR \& KNOBEL, 2008) e utiliza-se de procedimento exploratório, tendo como instrumentos de coleta de informações entrevistas narrativas e documentos para análise. 0 presente estudo utilizou-se das pesquisas de Gatti e Barretto (2009) e Gatti, Barretto e André (2011) como base para a discussão das informações obtidas. As informações apontam para: a conservação do curso normal em nível médio como a principal formação dos professores, apesar de todas as contradições que tencionam o tema; a manutenção de professores iniciantes como uma maioria nos anos iniciais e a necessidade da participação em programas formativos especificamente na área de alfabetização como possibilidade de aprendizagem concomitante com o trabalho que é desenvolvido; o protagonismo do formador e dos orientadores de estudos como meios estruturantes do processo formativo.

Palavras chave: Formação de professores. Alfabetização e letramento. Professor iniciante. 


\section{INTRODUÇÃO}

A necessidade de compreender os processos formativos, especificamente relacionados ao Pacto Nacional pela Alfabetização na Idade Certa (PNAIC) nasce da prática da pesquisadora como formadora de professores alfabetizadores e participante do PNAIC. Os desafios que a prática pedagógica impõe ao formador instigam a processos de investigação de maneira que se possa questionar o que se faz, compreender os processos e os resultados com um distanciamento que somente a pesquisa permite e, a partir dela, traçar novos objetivos para o trabalho.

Neste contexto, o desenvolvimento profissional do professor descrito por Day (2001), sobrevive em um mundo dominado pela mudança, pela incerteza e por uma complexidade crescente. Estes fatores determinam os formadores e os professores em formação que participam do programa, sendo necessário nos debruçar sobre esta realidade para questioná-la e procurar possíveis respostas.

Ainda Day (2001), nos ajuda a entender esta realidade quando considera as tensões demarcadas pela UNESCO (1996) que descrevem o panorama no qual os professores são formados em dois contingentes. Um deles designa o compromisso da educação para todos, demarca a extensão do período da escolaridade básica, reconhece a importância da formação permanente dos professores, dá maior ênfase a uma educação que prepare os jovens para a vida ao invés de um preparo vocacionado para determinadas destrezas específicas a empregos e firma uma tendência ao trabalho em equipe e colaborativo consonante com temas relacionados à educação ambiental, bem como à tolerância e compreensão mútua.

Outro lado é caracterizado por desigualdades crescentes e o aumento das diferenças sociais, como o fracasso na coesão social, o aumento de jovens alienados e que abandonam a escola, a elevação de taxas de desemprego juvenil e o argumento de que os jovens estão mal preparados para enfrentar o mundo do trabalho, admitindo a presença de tensões étnicas e raciais e os problemas relacionados com drogas e gangues associados à violência, além de problemas relacionados à competição determinada por valores materiais.

A par destas exigências, a totalidade de recursos atribuídos à educação tem diminuído. Esta situação manifesta-se de diferentes modos nos vários países. Por exemplo, em alguns deles, o aumento das turmas tem conduzido a uma deterioração das condições de ensino e de aprendizagem e à intensificação do trabalho dos professores (p. 26).

As demandas impostas à docência são cada vez mais complexas, tendo em vista a necessidade de o professor lidar com estudantes provenientes de diferentes níveis sociais e culturais e com capacidades de aprendizagem distintas e de promover uma variedade de situações de aprendizagem para responder a necessidades de motivações diversas, ao mesmo tempo em que necessita demonstrar conhecimento didático, também requer fundamentação teórica no seu campo de estudo, a fim de selecionar estratégias curriculares pertinentes ao contexto da sala de aula. "Espera-se que eles pensem sobre sua prática, que mudem e se desenvolvam profissionalmente enquanto aprendentes ao longo da vida, mas também se lhes exige que envolvam todos os alunos na aprendizagem promovendo o seu bem-estar e o seu desenvolvimento numa perspectiva holística" (FLORES, 2003, p. 129).

É neste cenário que o desenvolvimento profissional do professor alfabetizador se constitui, demandado pela sociedade do conhecimento, aberto às necessidades da escola no que diz respeito à singularidade de cada estudante, seus ritmos de aprendizagem, a cultura que cada um traz consigo, as oscilações de violência, as condições de trabalho e, sobretudo, com base nos conhecimentos e crenças que o professor obteve durante seu processo de formação até o enfrentamento das classes alfabetizadoras.

Nesse processo de constituição da carreira docente também ocorre um processo identitário do professor com sua atividade profissional, o qual, segundo Pimenta (2005), não é um dado imutável, uma vez que esse professor, sujeito da situação, é historicamente situado. Complementa que a identidade profissional se constrói a partir do significado social da profissão e das revisões das tradições.

A construção do processo identitário dos professores é determinado pelo meio social com que convive, pelas ações que realiza, sendo elas determinantes desse meio. André e Placco (2007) asseveram que os professores são sujeitos singulares de um dado contexto, cuja composição identitária sofre a influência desse contexto, ao mesmo tempo em que o compõe. 0 processo identitário, na carreira docente, também para Pimenta (2005), desenvolve-se por meio da rede de relações do professor com outros professores nas escolas, nos sindicatos, em outros agrupamentos, como a participação dos docentes no PNAIC. 
Para Constant (2015), as reflexões sobre a identidade profissional dos professores alfabetizadores, o baixo desempenho dos estudantes com relação à leitura e à escrita, dentre outros aspectos, desencadearam, nas atuais políticas públicas de educação a necessidade de atender às exigências de melhoria do aprendizado dos alunos. Para isso, as transformações eram necessárias sobre as práticas pedagógicas e a mobilização de conhecimentos presentes na teoria na Educação. Afirma:

Significava definir o que é essencial à alfabetização das crianças das escolas públicas. Para tal, era fundamental criar uma proposta para o professor alfabetizador a partir de um processo de formação continuada, marcado com a articulação de todas as políticas do MEC, o que deflagrou uma política de Estado ainda em construção. (p. 13)

O PNAIC é uma ação do Ministério da Educação que conta com a participação articulada do Governo Federal e dos governos estaduais e municipais com o objetivo de mobilizar esforços e recursos para a valorização dos professores e das escolas especificamente apoiando pedagogicamente os sistemas de ensino com materiais didáticos para as crianças do $1^{\circ}$ ao $3^{\circ}$ ano do ensino fundamental e na formação de professores e gestores da escola pública. Com o intuito de melhorar os sistemas educativos, ações governamentais são realizadas a fim de elevar os padrões de ensino e melhorar os padrões nos quadros das economias, o que aponta Hargreaves (1994, p. 5 apud DAY, 2001, p. 26).

A alfabetização ainda é um direito a ser conquistado por muitos brasileiros. Dados do Censo (IBGE 2010) apontam que entre 2000 e 2010, a taxa de analfabetismo no Brasil, até os oito anos de idade, diminuiu $28,2 \%$, com variações entre os estados da federação, alcançando uma taxa de alfabetização média de 84,8\%. Embora se constate certo avanço, o mesmo Censo indica que há variações regionais importantes, chegando a taxa de analfabetismo a $27,3 \%$ na região Norte e $25,4 \%$ no Nordeste.

O PNAIC não foi a primeira política pública do Governo Federal a almejar a melhoria do ensino de crianças no período da alfabetização, pois este mesmo, pode-se dizer, que é uma edição ampliada do Próletramento que o antecedeu, cm forte influência do PAIC (Programa de Alfabetização na Idade Certa), desenvolvido no Ceará. Em quatro de julho de 2012 o PNAIC é instituído pela Portaria no 867 que preconizava suas ações e definia suas diretrizes gerais. Em 14 de Dezembro de 2012 foi publicada no Diário da União a Portaria no 1.458, pelo então Ministro de Estado da Educação, interino, José Henrique Paim Fernandes, onde se previa no seu artigo $1^{\text {o }}$ a formação continuada de professores alfabetizadores, com o intuito de apoiar todos os professores que atuam no ciclo de alfabetização, incluindo turmas multisseriadas e multietapas.

Ao final de 2012 muitas universidades iniciaram a constituição de suas equipes de formação que iriam atuar nos mais de cinco mil municípios que aderiram às ações do PNAIC. 0 movimento entre a universidade e a escola foi um dos grandes marcos de aprendizagem para todos os participantes, aproximando diálogos necessários entre a pesquisa e a prática pedagógica, ou seja, entre os pesquisadores e os professores dos anos iniciais do ensino fundamental. Segundo os coordenadores de escrita dos cadernos de 2015, o ano de 2013 foi marcado pela implantação deste projeto de grande escala: o maior programa de formação de professores já desenvolvido pelo Ministério da Educação.

Este compromisso é corroborado por Araújo (2015, p. 22):

Ao aderir ao programa, os entes governamentais se comprometem a alfabetizar todas as crianças em língua portuguesa e em matemática, realizar avaliações anuais universais aplicadas pelo INEP, junto aos concluintes do $3^{\circ}$ ano do ensino fundamental e, no caso dos estados, apoiar os municípios que tenham aderido às ações do PNAIC para sua efetiva implementação.

Como proposta de formação, o PNAIC não propõe um método específico, mas apresenta várias sugestões metodológicas. Todo o processo de formação está constituído de modo a dar subsídio ao professor alfabetizador a ampliar estratégias de trabalho que atendam às necessidades de sua turma e, particularmente, de cada aluno em função do seu desenvolvimento e domínio da língua escrita que vai se modificando ao longo do ano letivo. As sugestões de atividades didáticas em todas as suas possibilidades, como: situações didáticas, sequências didáticas, projetos didáticos, são apresentadas no decorrer de todo o material de formação.

Imbernón (2009) aponta a formação permanente no século XX advinda das necessidades econômicas impulsionadas pela globalização, ou como prefere usar o termo, pela mundialização, por meio dos avanços tecnológicos que desembarcaram com força nos âmbitos da cultura e da comunicação trazendo consequências na produção de conhecimento. As funções dos professores intensificaram-se obscurecendo 
as fronteiras entre a docência e os demais enfrentamentos advindos de condicionantes sociais e biopsicológicos dos estudantes, aumentando as solicitações aos professores já potencializadas pela sociedade do conhecimento.

O princípio formativo do PNAIC não é o de estabelecer receitas para os seus cursistas, mas sim provocar a reflexão sobre as estratégias de ensino e aprendizagem diante de diversos temas que constituem o currículo do $1^{\text {o }}$ ao 3ํano. Além de apresentar a reflexão sobre o tema em si, promove a crítica do cursista a partir dos relatos de experiência que estão em todos os materiais.

\section{DESENVOLVIMENTO}

Com o objetivo de compreender as ações dos professores do $1^{\circ}$ ao $3^{\circ}$ ano de uma rede municipal de ensino da região metropolitana de Curitiba, no Paraná, foi proposta a aplicação de uma entrevista narrativa e análise documental. Lankshear e Knobel (2008) afirmam que a pesquisa pedagógica contribui para melhorar a percepção do papel e da identidade profissional dos professores, pois como profissionais os professores não se limitam a seguir meramente normas impostas verticalmente a eles.

A pesquisadora percorreu 10 escolas do referido município juntamente com a equipe administrativa da Secretaria Municipal De Educação, fato que trouxe relevância ao processo e em contrapartida oportunizou aos membros desta equipe realizar visitas às escolas para acompanhamento do processo educacional. Este processo ocasionou total participação da pesquisadora com o meio pesquisado, trazendo possibilidades de compreensão sobre o movimento da alfabetização no município para além dos instrumentos previstos inicialmente.

Ao chegarmos a cada instituição de ensino desta rede, a equipe pedagógica apresentava a proposta de pesquisa e encaminha a organização de um espaço para que houvesse uma sala exclusiva na qual a entrevista pudesse ocorrer sem interferências. Outro aspecto da estrutura foi buscar um professor que estivesse em permanência que substituísse o professor que concederia a entrevista e os materiais para a análise. Todos os professores que participaram da entrevista leram o termo de consentimento livre e esclarecido, obtiveram as informações desejadas sobre o estudo e após este momento inicial é que efetivamente o processo iniciou com cada participante.

Participaram da pesquisa nos meses de maio a julho de 2015, 27 professoras alfabetizadoras, na sua totalidade mulheres, por isso serão sempre referenciadas neste gênero. Quanto aos dados sociodemográficos, essas professoras têm entre 23 e 59 anos, conforme indica o Gráfico 1:

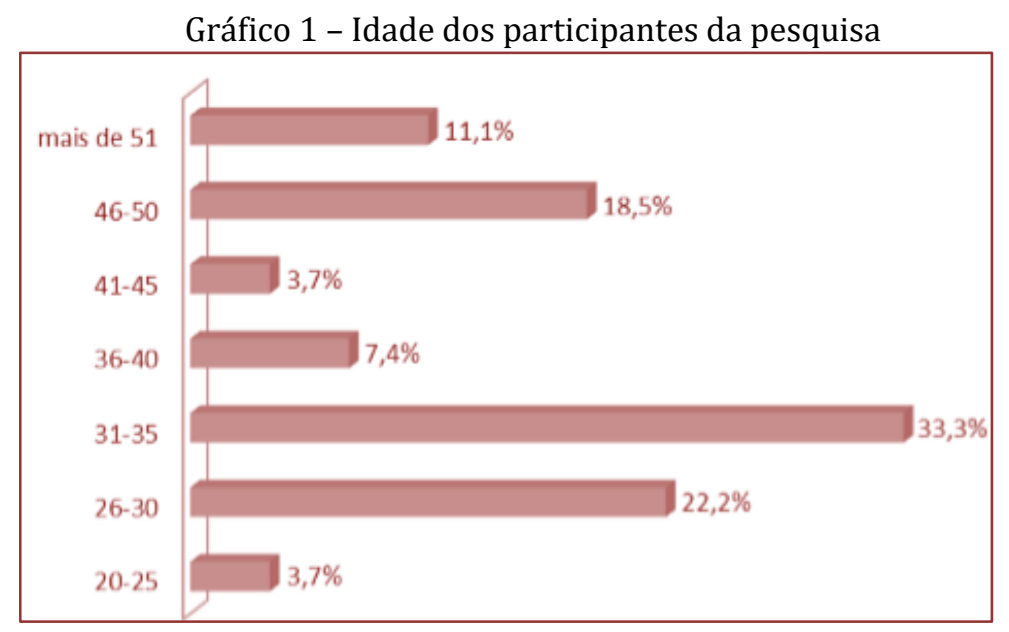

Fonte: dados coletados pela autora.

Das 27 participantes 3,7\% têm entre 20 e 25 anos, 22,2\% entre 26 e 30 anos, 33,3\% entre 31 e 35 anos, sendo estas duas últimas faixas de predomínio, pois somando-as totalizam 55,5\%. Do total de participantes 7,4\% têm de 36 a 40 anos, 3,7\% está entre 41 a 45 anos, 18,5\% está entre 46 e 50 anos e 11,1\% têm mais de 51 anos. Observa-se ainda um predomínio de professoras mais jovens trabalhando com as crianças em fase de alfabetização. 
No que diz respeito à formação acadêmica, também foi possível notar a opção pelo Ensino Médio na Modalidade Normal, ou para as professoras que cursaram ainda na Lei 5692/71, o curso de Magistério. 0 Gráfico 2 ilustra a preferência. Foi utilizado um único grupo, já denominado pela nova nomenclatura "Modalidade Normal".

Gráfico 2: Formação em nível médio das participantes

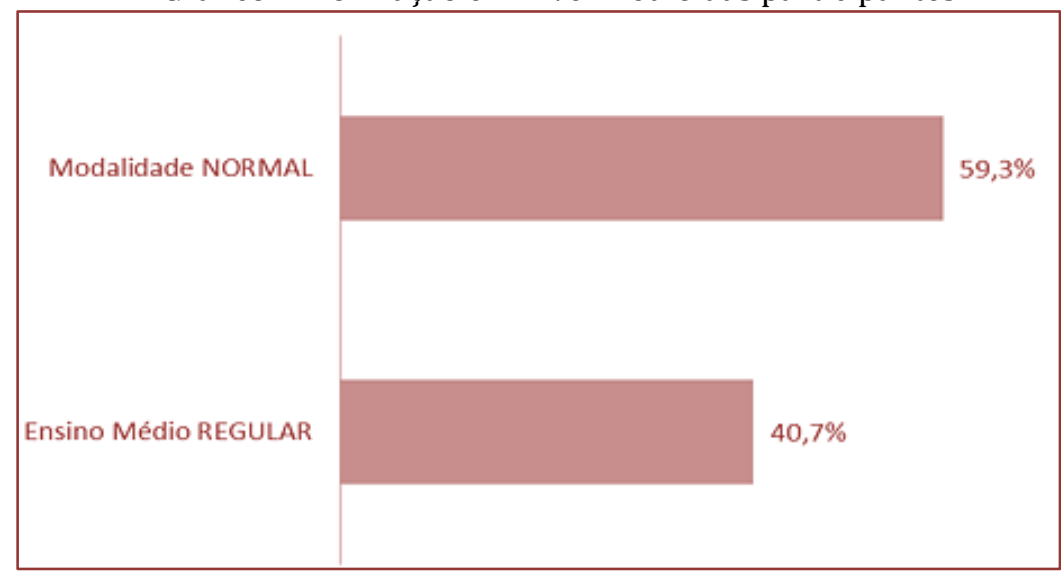

Fonte: dados coletados pela autora

Das 27 participantes 41\% cursaram o Ensino Médio regular e 59\% optaram pelo Curso Normal, iniciando a formação acadêmica relacionada à docência já em nível médio. Apesar das controvérsias sobre o tema, da sabida necessidade dos professores graduarem-se em nível superior, há alguns aspectos polêmicos a considerar: a subsistência do curso Normal não é só um fato da Lei 9394/96 em seu artigo 62 que enfatiza a formação do professor preferencialmente em nível superior, mas admite o curso Normal (em nível médio), existe de fato uma procura deste curso, mesmo com todas as suas controvérsias. Outro aspecto é a legitimidade que as participantes atribuem ao curso como um tempo importante de aprendizagem, especialmente na área de alfabetização e se comparado ao ensino superior, há quem afirme que aprendeu mais no curso Normal de nível médio do que no ensino superior. Ainda que a pesquisa de Gatti e Barreto (2009) sobre formação de professores tenha sua especificidade para o ensino superior, a reflexão a seguir é plausível para o momento:

0 preparo insuficiente dos futuros professores para ensinar conteúdos tradicionais escolares, ainda que em nível de iniciação, exige uma reflexão mais aprofundada sobre a suficiência ou adequação da formação polivalente e da perspectiva interdisciplinar (p.128).

Seguindo o curso sobre formação acadêmica, o Gráfico 3 menciona os dados acerca da formação em nível superior.

Gráfico 3: Formação em nível superior das participantes

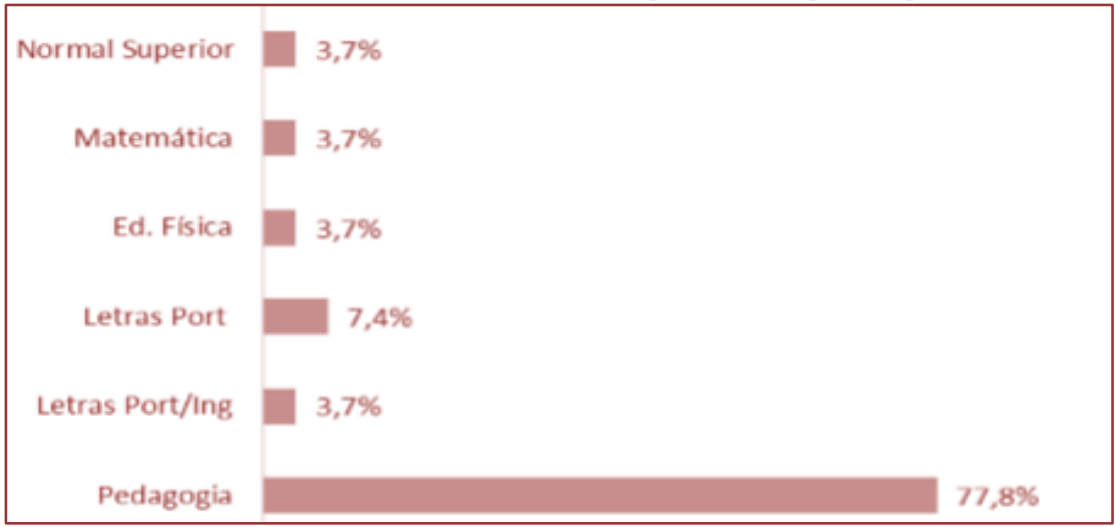

Fonte: dados coletados pela autora 
Dos 27 participantes 77,8\% graduaram-se em Pedagogia, 3,7\% no Normal Superior, curso este que surgiu com a Lei 9394/96 como uma oportunidade aligeirada para obter título em nível superior para os professores da Educação Infantil e dos Anos Iniciais do Fundamental já em serviço, 3,7\% possuem licenciatura em matemática, 3,7\% licenciatura em educação física, 7,4\% licenciatura em letras - português e 3,7\% licenciatura em letras inglês-português. 0 predomínio da formação em Pedagogia não é uma novidade, entretanto reforça a preocupação com a formação que este curso oferece, ao analisar as ementas dos cursos, conforme assinalam Gatti e Barreto (2009, p. 121):

A análise do conteúdo das ementas indica, no entanto, que nas disciplinas referentes aos conhecimentos relativos à formação profissional específica também predominam enfoques que buscam fundamentar enfoques de diversas áreas, mas pouco exploram seus desdobramentos em termos das práticas educacionais.

Esta ideia é corroborada por Gatti, Barreto e André (2011, p. 117):

Aponta-se para a necessidade de uma atuação política mais incisiva (...) porque o problema da formação do(a) licenciado(a) como profissional professor(a) se acha descurado de sua qualidade na direção do perfil de profissional com condições mínimas de adentrar em uma escola em que crianças e jovens em desenvolvimento dependem de seu trabalho para chegar à cidadania plena.

Outro aspecto investigado foi o tempo de docência em classes alfabetizadoras das participantes desta pesquisa, tendo em vista que é histórico ouvir que professoras iniciantes são convidadas a assumir turmas de alfabetização. Não foi diferente nesta pesquisa. 0 Gráfico 4 traz em números o fato.

Gráfico 4: Tempo de docência em classes alfabetizadoras

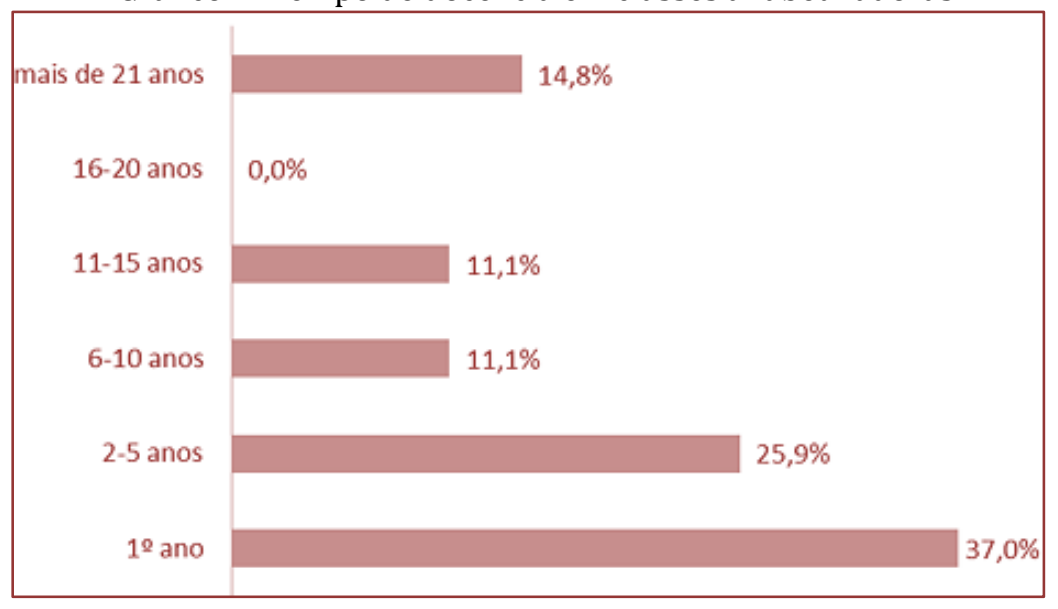

Fonte: dados coletados pela autora

Pode-se observar que das 27 participantes, 37\% estão no seu primeiro ano de docência atuando em classes alfabetiozadoras, $25,9 \%$ possume de 2 a 5 anos nestas classes, o que se considera também uma fase de início de carreira. Se somados os dois recortes inciais, que abrabgeria do primeiro ano de docência ao quinto, temos 62,9\% das participantes. De 6 a 10 anos há 11,1\%, de 11 a 15 anos, também 11,1\%, de 16 a 20 anos não há e com mais de 21 anos há14,8\%. Os números corroboram para uma prática constante, não exclusiva deste município pesquisado, que é a prevalência de professores iniciantes em classes alfabetizadoras, sendo estas classes detentoras de tensões e desafios que os professores na medida que se mantém nas instituições vão assumindo outros anos ou outras funções nos espaços escolares. São poucos os professores ditos experientes que se mantém atuantes nestas classes.

Diante do exposto, uma das investigações foi entender o papel do PNAIC na formação dos professores e pode-se notar que na sua maioria já participaram das edições de 2013 e 2014, conforme o Gráfico 5 aponta. Ao perguntar para as professoras, sujeitos desta pesquisa, se participaram ou não do PNAIC e suas implicações na formação, foram unânimes em afirmar que foi muito produtivo e para quem ainda não participou, gostaria de participar no próximo ano. 
Gráfico 5: Participação das respondentes no PNAIC 2013/2014

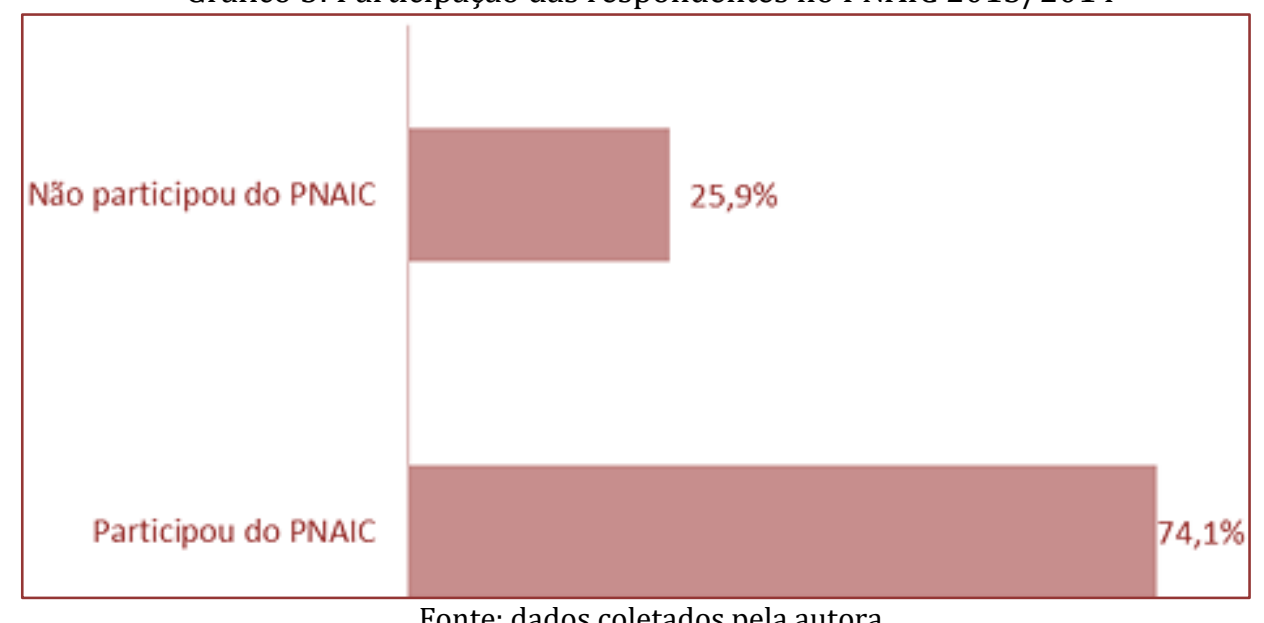

Fonte: dados coletados pela autora

Com a leitura do Gráfico 5 é possível compreender que boa parte dos 27 participantes desta investigação já participaram de alguma edicação do PNAIC totalizando $74,1 \%$. Os $25,9 \%$ que ainda não participaram afirmam que têm o iteresse, provavelmente mobilizados pelas verbalizações dos particpantes, conforme assinala a Professora 13: "Achei uma prática muito válida, auxiliou na minha prática em sala de aula". Ainda a Professora 9 corrobora:

Sempre gostei da alfabetização e pude rever minhas práticas. O PNAIC me ajudou em termos de ter certeza do que eu estava fazendo e estar cobrando das professoras as sequências didáticas. Eu vim de escola particular e senti muita diferença e acho que deveria ser no mesmo ritmo. Tem que ser alfabetização e letramento no sentido literal e saber que a criança vai ler e escrever em todas as disciplinas.

A referida participante foi cursista do PNAIC no ano de 2013, na edição de Língua Portuguesa e a ênfase foi nos aspectos de leitura, escrita, Sistema de Escrita Alfabética, tendo como estratégia a sequência didática (SD). Foi possível observar como esta opção metodológica incorporou-se ao trabalho das alfabetizadoras.

Quando a Professora 15 relata uma prática interdisciplinar desenvolvida, refere-se à SD como estratégia: "Uma sequência didática desenvolvida nesse ano com cantigas de ninar. A partir disso desenvolvi questões de matemática e português. Na artes os alunos produziram uma mandala".

0 protagonismo do professor como orientador de estudos junto às alfabetizadoras e na dinâmica da formação presencial vem produzindo oportunidades de todos os profissionais participantes do PNAIC dialogarem sobre a alfabetização seguindo orientações que perseguem um eixo comum: o letramento. 0 PNAIC preconiza a alfabetização como um processo que prioriza o letramento e oferece aos cursistas ampla variedade de estratégias sobre a oralidade, a leitura e a escrita, sua sistematização por meio do Sistema de Escrita Alfabética e seus usos sociais. Defende que é necessário que a criança domine o Sistema de Escrita Alfabética, mas também desenvolva habilidades de fazer uso desse sistema em diversas situações de comunicação com autonomia.

A Professora 20 também aponta a SD como uma estratégia que possibilita a ação interdisciplinar:

Trabalhei a sequência didática do Monteiro Lobato, consegui abordar todas as disciplinas. Divertido, as crianças lembram até hoje. Fizemos a leitura do Monteiro Lobato, escolheram uma música (da Emília) trabalhamos as características dos personagens, onde eles moravam, fazenda, campo.

As sequências didáticas permitiram aos professores alfabetizadores uma organização metodológica do trabalho pedagógico tendo como princípio eventos de letramento, ou seja, o uso de textos com significado para os estudantes e a partir destes realizar um desdobramento de atividades que sustentam as análises, complementam e ampliam a compreensão do tema. É por meio das sequências didáticas ou como muitas professoras ainda usam, projetos pedagógicos, que o Sistema de Escrita Alfabético (SEA) ganha um cenário para que os estudantes se apropriem deste com situações contextuais e reflexivas sobre a língua. 


\section{CONSIDERAÇÕES FINAIS}

Este estudo permitiu a leitura de algumas informações no campo da alfabetização que não são novas, entretanto, são difíceis de trabalhar com uma possibilidade de superação. Traz no seu bojo aspectos que se constituem como costumes que outrora poderia se pensar em algo superado, como por exemplo: a manutenção de grande parte das professoras cursarem o Normal em nível médio e a grande incidência de professoras iniciantes nas classes alfabetizadoras.

Entrelaçando as funções formativas do PNAIC com os estudos relacionados à formação continuada de professores e as tensões que o trabalho com os anos iniciais constituem naturalmente frente aos desafios naturais do ensino da leitura e da escrita, especialmente no Brasil, pode-se considerar diante deste estudo alguns princípios. Princípios que não constituem como propostas, mas como sínteses reflexivas desta pesquisa.

O campo de ensino da leitura e da escrita requer cada vez mais profissionais experientes, com capacidade criativa e com possibilidades de enfrentamento da diversidade de estudantes que compõem as classes alfabetizadoras. Em contrapartida, as informações do estudo mostram que ainda temos um predomínio de professores iniciantes que assumem o ensino das classes alfabetizadoras, sendo mais do que necessário programas de formação continuada paralelos ao trabalho do professor de maneira que subsidiem a prática pedagógica e amplifiquem as condições de ações práticas, tendo em vista os problemas já encontrados na formação inicial conforme pesquisas como a de Gatti e Barreto (2009).

É natural, como entendimento de desenvolvimento de carreira que professores experientes assumam outros postos, como ações administrativas ou até mesmo a formação de novos professores, ficando aos novos professores a tarefa de ensinar crianças pequenas. Não se pode olhar para esses números encontrados como um problema, mas como um movimento natural da carreira docente.

Exatamente por essas condições é que o PNAIC em suas estratégias formativas assume um protagonismo ímpar com os professores em rede nacional, pois possibilita aos mais experientes assumirem a orientação aos iniciantes e nesta dimensão proporcionam a revisão de conceitos e práticas conforme as propostas dos cadernos em estudo. As limitações existem pela contingência do que se propõe, entretanto, se os participantes estudarem e colocarem em prática o proposto já é uma vitória para largos passos que a educação brasileira necessita como superação.

Para além das informações obtidas por meio das professoras participantes que enriqueceram sobremaneira o estudo aqui exposto, é necessário evidenciar as informações da equipe administrativa sobre os cuidados que demandam para o período de alfabetização. Sabem que há muitas professoras iniciantes nas classes alfabetizadoras e usam de uma estratégia para que participem do PNAIC como uma possibilidade de garantir a este grupo um processo de formação específico na área de alfabetização. Demonstram credibilidade ao programa e apoiam as ações que dele são exigidas às escolas.

Organizam anualmente avaliações internas na secretaria municipal de educação deste município com o intuito de acompanhar as necessidades dos estudantes e dos professores, atuando incisivamente no que os dados mostram, ou seja, os dados não se paralisam no papel, mas são usados como fonte de trabalho e intervenção nas ações da equipe pedagógica. Nesta direção entendem as ações do PNAIC como garantia de uma qualificação necessária às professoras alfabetizadoras e em sintonia com um coletivo nacional que vem discutindo saberes necessários aos professores que atuam em classes do $1^{\circ}$ ao $3^{\circ}$ ano.

A responsabilidade por melhorias nas taxas de alfabetização dependem efetivamente de um compromisso assumido por todos: instâncias superiores, como o Ministério da Educação, Secretarias de Estados, Secretarias de Municípios, Escolas, Formadores e Professores, dentre outros atores nesta rede de ação com um objetivo: promover a leitura e a escrita com qualidade para todos os brasileiros. Parece um objetivo tão pequeno, tão simples, entretanto, num país que guarda uma história singular de analfabetismo, de acesso à leitura e à escrita para uma elite, democratizar este processo com possibilidades equitativas é uma luta diária a todos os envolvidos e que acreditam na causa.

Como todo o estudo qualitativo, ocupo-me das palavras de Freire (1995), quando enfatiza a necessidade de re-ler as experiências de diferentes fases da vida como mote para a constituição do ato crítico de ler, reler as experiências docentes, re-ler as informaç̧ões aqui postas, re-ler as interpretações são convites incessantes para a novas perguntas. E que venham! 


\section{REFERÊNCIAS}

[1] Andre, Marli E. D.; Placco, Vera Maria N. de Souza. Processos psicossociais na formação de professores: um campo de pesquisas em Psicologia da Educação. Contrapontos. Itajaí, v. 7, n. 2, p. 339-346, março/agosto. 2007. Disponível em: <http://www.google.com.br/\#sclient=psy\&hl=pt-BR\&rlz=1R2RNRN_ptBRBR430\&source=hp\&q=contrapontos+marli+andre+e+vera+placco\&rlz=1R2RNRN_pt-

Brbr430\&aq $=f \& a q i=\& a q l=\& o q=\& p b x=1 \& b a v=o n .2, o r . r \_g c . r \_p w . \& f p=a c 8505566 c 70 e 94 a \& b i w=1348 \& b i h=515>$. Acesso em: maio de 2011.

[2] Araújo, Mirna França da Silva de. Trajetória de implementação de uma política pública de formação continuada de professores alfabetizadores: o PACTO. In: Brasil. Secretaria de Educação Básica. Diretoria de Apoio à Gestão Educacional. Pacto Nacional pela Alfabetização na Idade Certa. Interdisciplinaridade no ciclo de alfabetização. Caderno de Apresentação. Ministério da Educação, Secretaria de Educação Básica, Diretoria de Apoio à Gestão Educacional. - Brasília: MEC, SEB, 2015.

[3] Constant, Elaine. Contextos de criação do Pacto Nacional Pela Alfabetização na Idade Certa. In: Brasil. Secretaria de Educação Básica. Diretoria de Apoio à Gestão Educacional. Pacto Nacional pela Alfabetização na Idade Certa. Interdisciplinaridade no ciclo de alfabetização. Caderno de Apresentação. Ministério da Educação, Secretaria de Educação Básica, Diretoria de Apoio à Gestão Educacional. - Brasília: MEC, SEB, 2015.

[4] Day, Christopher. Desenvolvimento Profissional de Professores: os desafios da aprendizagem permanente. Tradução Maria Assunção Flores. Porto, PT.: Porto Editora, 2001.

[5] Flores, Maria Assunção. Dilemas e desafios na formação de professores. In: Moraes, Maria Célia; Pacheco, José Augusto; Evangelista, Maria Olinda (orgs.). Formação de Professores: perspectivas educacionais e curriculares. Porto, PT.: Porto Editora, 2003. cap. 7, p. 127-160.

[6] Freire, Paulo. A importância do ato de ler. São Paulo: Cortez, 1995. Coleção Polêmicas do nosso tempo.

[7] Gatti, Bernadete Angelina (Coord.); Barreto, Elba Siqueira de Sá. Professores do Brasil: impasses e desafios. Brasília: Unesco, 2009.

[8] Gatti, Bernadete Angelina; Barretto, Elba Siqueira de Sá; André, Marli Eliza Dalmazo de Afonso. Políticas docentes no Brasil. Brasília: Unesco, 2011.

[9] Ibge. Censo 2010. Disponível em: <http://censo2010.ibge.gov.br/>. Acesso em: julho de 2015.

[10] Imbernón, Francisco. Formação permanente do professorado: novas tendências. São Paulo: Cortez, 2009.

[11] Lankshear, Colin; Knobel, Michele. Pesquisa Pedagógica: do projeto à implementação. Porto Alegre: Artmed, 2008.

[12] Pimenta, Selma Garrido (Org.). Saberes pedagógicos e atividade docente. 4. ed. São Paulo: Cortez, 2005. 


\section{Capítulo 17}

Domínio teórico-prático das teorias pedagógicas de aprendizagem presentes no discurso dos docentes do curso de direito de um Campus da Universidade do Estado de Mato Grosso

Solange Teresinha Carvalho Pissolato

Silvana Mara Lente

Edson Roberto Oaigen

Resumo: Trata-se de um estudo com o objetivo de examinar o domínio teórico-prático das teorias pedagógicas de aprendizagem presentes no discurso dos docentes do curso de Direito através de aplicação de questionário misto relacionando com os princípios selecionados de cada teoria. 0 qual foi desenvolvido por meio de pesquisa descritiva, qualitativa, e, bibliográfica, com a utilização do método hermenêutico para a construção da interpretação dos dados coletado junto os docentes. É evidente que não se pretendeu com esse estudo esgotar a temática ampla e abrangente aqui trabalhada. Todavia, os diversos apontamentos dos teóricos e olhares docentes se entrecruzam em temas avaliados como de interesses de educadores, pesquisadores, professores e estudantes, sobretudo daqueles que defendem a educação. Ao concluir, registra-se marcantes divergências entre os discursos docentes e as teorias, não havendo concordância entre os indicadores para determinada teoria, se contradizendo mesmo nos discursos, onde relatam perfil cognitivista com acentuada incidência em Skinner ou em Rogers.

Palavras-chave: Teorias pedagógicas, perfil docente. 


\section{INTRODUÇÃO}

Rauber (2008) lembra que com a globalização a universidade vive entre a regulamentação e a mercantilização do ensino, e a educação superior como um direito público a ser ofertado pelo Estado gratuitamente, com qualidade, democracia e comprometido com a dignidade do povo brasileiro. Isto já é vivenciado na universidade em estudo, visto que se trata de uma universidade pública estadual que se destaca por sua responsabilidade social junto à comunidade matogrossense, considerada especialmente no que se refere à sua contribuição em relação à inclusão social, ao desenvolvimento econômico e social, a defesa do meio ambiente, da memória cultural, da produção artística e do patrimônio cultural.

Michavila (2000) apresenta os seis grandes desafios que a universidade atual tem que enfrentar: adaptarse as atuais demandas do mercado, situar-se em um novo contexto de competitividade social, melhorar a administração, incorporar as novas tecnologias, tanto na administração como na docência, organizar-se como força motriz do desenvolvimento da região a qual pertence, e situar-se em um cenário novo, globalizado, de formação e emprego, adaptando a ele suas próprias estratégias formativas. Os quais acrescidos a afirmativa de França (2015, p. 14): "Interagir os conceitos com o mundo cotidiano é, antes de tudo, refletir o papel do educador, não como mero transmissor de informações, pois estas tecnologias já fornecem aos alunos".

Demonstram que há muito o que se discutir e destacar neste movimento do ensino superior no Século XXI. Porém, Franco (2015, p. 34) refletindo quanto as políticas de reformulação das IES, afirma que já vem ocorrendo "(...) modificações significativas no conjunto que se forma o ensino público superior, ajustando a sociedade acadêmica aos diversos espaços de construção de conhecimentos que ao longo do tempo vem garantindo a qualidade e desenvolvimento institucional".

É neste prisma que se busca contextualizar este estudo, pois se por um lado o Campus de Diamantino MT representa um campus novo para a Universidade do Estado de Mato Grosso, por outro já tem a responsabilidade e o compromisso de atuar de maneira a atingir a qualidade de ensino superior, com práticas educativas inovadoras e com o compromisso de atingir o previsto na missão, visão e valores institucionais.

Ou seja, ofertar ensino superior gratuito e de qualidade, além de contribuir com a formação de profissionais de diversas áreas, possibilitando o desenvolvimento do estado de Mato Grosso a partir do ensino, da pesquisa e da extensão. Partindo desta premissa e com base nas afirmativas a seguir onde Rauber (2008), Michavila (2000) e França (2015) tecem profundas considerações sobre o papel da universidade neste mundo globalizado e a prática pedagógica como eixo norteador nesse processo de formação profissional é que se delineia o objeto de estudo aqui apresentado.

\section{METODOLOGIA}

Trata-se de uma pesquisa qualitativa que segundo Silva (2005) compreende a interpretação das interpretações dos sujeitos sobre as suas perspectivas, os fatos que testemunham e as suas práticas.

Privilegia a análise de micro processos por meio do estudo das ações sociais dos indivíduos e dos grupos, e parte do princípio de que o homem é produto e produtor de um constructo mental intersubjetivo, o qual orienta a sua percepção sobre a realidade.

No que tange aos procedimentos técnicos compreende uma pesquisa bibliográfica elaborada a partir de material já publicado, constituído principalmente de “(...) livros, artigos de periódicos e atualmente com material disponibilizado na Internet; utiliza-se também do levantamento: considera a interrogação direta das pessoas cujo comportamento ou situação se deseja conhecer" (Silva, 2005, p.21).

Com vistas a verificar como os docentes se movimentam dentro das teorias pedagógicas de aprendizagem foi elaborado e aplicado um instrumento de coleta de dados desmembrado em três momentos: 0 formulário traz preliminarmente a Matriz conceitual contendo os Teóricos representantes de cada Teoria psicopedagógica alinhados com indicadores selecionados, o qual servirá de aporte teórico.

Na parte I: 0 questionário é constituído de 15 questões objetivas por bloco perfazendo um total de seis blocos, de acordo com cada indicador da pesquisa, os blocos de 15 questões contem três questões marcadas por traços característicos de cada teoria psicopedagógica. Cada bloco de questões apresenta como critério de avaliação: onde o entrevistado deverá assinalar cinco características dos critérios apresentados, por bloco. Este instrumento foi aplicado aos docentes selecionados do curso de direito. 
Após o preenchimento da primeira parte passa-se à segunda com a apresentação de itens com características apresentadas de forma aleatória dos teóricos onde o docente identificou com a inicial do nome do teórico a frase que melhor o representa, preenchendo os parênteses com as letras iniciais do respectivo teórico: A (Ausubel), P (Piaget), R (Rogers), S (Skinner) e V (Vygotsky) dependendo da Teoria a que pertence a afirmativa e analisando características de seu perfil enquanto docente. Ainda consta deste instrumento perguntas fechadas com as variáveis sexo, faixa etária, formação acadêmica, titulação, regime de trabalho, tempo de atuação no ensino superior, a fim de traçar perfil docente o que contribui para as discussões deste estudo.

O Método Hermenêutico aqui aplicado para interpretação e análise dos dados coletados tem que o termo "hermenêutico provém do grego "hermĕneuein" significa declara, anunciar, interpretar, esclarecer, e por último traduzir. Significa que alguma coisa é tornada compreensível ou levada a compreensão. Para Ghedin (2011) o Método Hermenêutico propicia ao pesquisador a oportunidade de conceber uma metodologia e um discurso decifrador da realidade ou do contexto em que acontece o objeto pesquisado.

\section{RESULTADOS E DISCUSSÕES}

0 docente em algum momento na sua carreira acaba por se autoavaliar, nesta oportunidade os mesmos puderam se autoavaliarem a partir das semelhanças entre seu fazer pedagógico e as afirmativas constantes nas Teorias de Skinner, Piaget, Vygotsky, Ausubel e Rogers.

Os resultados encontrados neste estudo apontaram que Skinner prevaleceu nas mais apontadas pelos docentes, com 07 indicações se assemelhando ao tratado por Faria (s/d) ao afirmar que no ensino superior para exercer o papel de professor basta ter domínio do conteúdo que será lecionado. Apontando para que seja levado em conta a prática pedagógica, ou seja, tanto o aspecto do conhecimento específico quanto o aspecto pedagógico. 0 que ratifica Pimenta; Anastasiou (2010) ao afirmar que no Brasil não existe curso de formação docente para o ensino superior, basta ter conhecimento de determinado conteúdo, ou ainda ser um bom pesquisador.

Em segunda colocação se apresenta que o professor se caracteriza como àquele capaz de criar situações problemas, como detalhado por Piaget em sua teoria. 0 que fica temeroso ratificar esses resultados, uma vez que os mesmos já consideram serem os detentores do conhecimento e pleno domínio para o trabalhar em sala de aula, como seria possível simular situações problemas se este processo é construído com a orientação do educando ao educador e não pelo mero repasse de conteúdo já concebidos e transmitidos pelos professores? Opta-se por assemelhar-se as considerações de Almeida (2012) a qual considera que os docentes desconhecem cientificamente os elementos que compõem a prática docente; como metodologias e estratégias didáticas, avaliação e peculiaridades da interação professor-aluno essenciais para os processos de ensino-aprendizagem, o que pode mascarar está afirmativa encontrada.

Em terceira colocação os resultados apontaram traços de Rogers e Vygotsky, com cinco indicações, que na mesma linha da discussão anterior, acredita-se que não se tem como acreditar em pleno domínio do conteúdo a ser repassado para os discentes e a oportunidade dada ao aluno de construir seus conceitos, sobretudo por não respeitar o contexto social e cultural, cabendo assim, ser verificada está divergência entre o discurso docente, a vivencia registrada pelo discente e a ser observada pela pesquisadora, afim de validar a afirmativa aqui discorrida.

Já reforçava Pimenta; Anastasiou (2010) que se o professor é licenciado teve a oportunidade de discutir elementos teóricos e práticos relativos à questão do ensino aprendizagem, ainda que direcionado a outra faixa etária de alunos. Mas se gradou-se em bacharelado, ocorrerão deficiências na compreensão das funções e objetivos da educação superior e necessidade de formação específica para atuação na docência.

0 que resta ser comprovado é se por meio do método tradicional, skinneriano ocorre ou não o conhecimento? Ficando como sugestão de futuro estudo nesta linha de investigação. É com ênfase em Vasconcelos; Amorim (s/d) onde reconhecem que a relação professor x aluno podem produzir efeitos positivos ou negativos, sobretudo por se tratarem de seres de relação existencial onde ambos representam um par complexo dinâmico, que este item foi abordado neste estudo. 
Quanto a concepção dos docentes quanto a relação estabelecida entre educador e educando, observa-se a incidência de Piaget e Rogers com três alternativas indicadas, seguido de Vygotsky e Ausubel com duas indicações e por fim Skinner com apenas uma indicação. Tornando evidente como os docentes passeiam a partir de seus discursos nas teorias.

Assim, é possível destacar que os docentes se visualizaram nas teorias cognitivista e humanista em primeiro plano, caracterizando uma relação mista entre os preceitos de ser centrada no aluno e mediada pelo professor, a qual ocorre em clima de igualdade sem exercício de sobreposição. 0 que se assemelha aos achados de Viotto Filho (2009) quanto se refere que no ensino superior devem ser proporcionados trabalhos e situações variadas ao aprendiz onde o docente se posiciona como um orientador, um provedor de desafios cognitivos proporcionando aprendizagens significativas no sentido da compreensão, do domínio do conhecimento e do processo de conhecer, tornando os aprendizes sujeitos da construção do conhecimento.

Tem-se que a teoria de Piaget sobre a construção do conhecimento, apesar de não ser nova, mantêm ainda hoje uma importância muito grande para explicar a gênese e o desenvolvimento da inteligência no ser humano.

Muitos teóricos e pedagogos têm utilizado/adaptado esta teoria ao ensino e educação, e alguns autores, partindo desta base, desenvolveram outras teorias sobre a mesma temática. Bem como a abordagem Rogeriana é basicamente humanista e visa à aprendizagem "pela pessoa inteira", uma aprendizagem que transcende e engloba as aprendizagens cognitiva, afetiva e psicomotora.

O homem é inerentemente bom e orientado para o crescimento, sob condições favoráveis, não ameaçadoras, procurará desenvolver suas potencialidades ao máximo, assim a abordagem quanto ao ensino é de que a aprendizagem é centrada no aluno e na sua potencialidade para aprender. Assim, acredita-se que ambas se completam em prol de uma aprendizagem socialmente mais útil, no mundo moderno, é a do próprio processo de aprender, uma contínua abertura à experiência e a incorporação dentro de si mesmo, do processo de mudança.

Em relação à percepção dos docentes quanto as características do discente no contexto atual os resultados apontaram predomínio de Rogers, ou seja, àquele que se configura como centro da aprendizagem, seguido de Piaget, Ausubel e Vygotsky. Como já mencionado as características marcantes se concentram em Rogers sendo o mesmo considerado sujeito da aprendizagem, centro do processo de aprendizagem e envolvido nele.

Respaldado no próprio teórico, que afirma que o único homem educado é o que aprendeu a aprender; o homem que aprendeu a adaptar-se e mudar; que percebeu que nenhum conhecimento dá uma base para segurança.

Assegura Silva (2017) a partir da teoria de Rogers que a realidade é um fenômeno subjetivo, as pessoas no centro assim como a confiança na sua capacidade para superar as circunstanciam diversas. 0 "eu" do indivíduo, portanto, irá perceber diferencialmente o mundo. Assim, se concebe que existe fortes evidencias quanto ao desenvolvimento científico desses acadêmicos, requerendo um aprofundamento de outros estudos para verificação quanto ao nível de conhecimento elaborado e concebido pelos alunos.

As teorias cognitivistas de Piaget, Ausubel e Vygotsky também se configuraram neste item com um empate nas indicações, mostrando que também o discente tem um perfil cognitivo, interacionista e participante dentro de um processo sócio histórico, no processo de aprendizagem, devendo estes serem assistidos pelos docentes, assim, acredita-se que ao mesmo tempo que estes podem construir conhecimentos sozinhos a partir do já concebido e do novo, dependem da mediação e orientação dos docentes.

Em se tratando de características enquanto educador, os docentes assinalaram um misto entre as teorias de Skinner, Ausubel e Piaget. Os resultados apontam que embora o docente se caracterize como mediador, orientador, estes descrevem que se encaixam na teoria de Skinner quando se trata de planejamento fechados e instruções programadas, com a facilitação da aprendizagem.

Os resultados quanto as características do processo ensino aprendizagem apontam prevalência no teórico Vygotsky com três alternativas assinaladas, contribuindo assim para a definição que no processo ensinoaprendizagem ocorre a busca da construção de significados, com evidencia nas palavras e nos discursos, onde as funções mentais superiores se originam como relações entre seres humanos. Assim, a troca de experiência e a influência do meio interferem no processo de aprendizagem. 
O que ratifica Lima (2017) as influências sociais são de extrema importância para o desenvolvimento cognitivo, pois Vygotsky compreende que as partes biológicas por si só não conseguem realizar a aprendizagem no seu todo. Porém os resultados se contrapõem com outras características já discutidas aqui, levando a um questionamento: como um professor centralizador pode ser mediador?

Por fim o último indicador, à avaliação, onde Moura e colaboradores (2012) tecem reflexões quanto a este processo a ser aplicado no ensino superior, elencando a elas a necessidade de conhecimento das teorias utilizadas, para que se estabeleça com clareza o que vai ser avaliado e selecione a técnica adequada para avaliar. Aqui, tanto na escolha por alternativas ou pela organização por teóricos, prevaleceu Ausubel, com uma pequena alteração para Piaget nas alternativas que foram assinaladas duas como as de Ausubel.

Agora, a partir dos resultados e compreendendo a avaliação em Ausubel focada primordialmente na aprendizagem cognitiva, a partir do conhecimento prévio do aluno (Silva, 2017) e em Piaget se configura durante o processo ensino-aprendizagem e está diretamente interligada ao ensino, logo, ocorre continuamente por meio da observação sobre o fazer do aluno como informa Oliveira (1994); registra-se uma divergência aqui, embora ambas teorias sejam cognitivista, a primeira valoriza as competências e habilidades e a segunda é contínua a partir da assimilação e acomodação. A avaliação em Piaget é caracterizada como uma ferramenta para auxiliar no processo ensino- aprendizagem.

O que foi reconhecido por Diaz (2011, p.165) como “(...) reconstrutivista e desenvolvedora; ao mesmo tempo em que estimula a consciência do erro, elimina-o e desenvolve a experiência do aprendiz. " A Teoria de Piaget, em resumo, trata sobre a construção do conhecimento, e apesar de não ser nova, mantêm ainda hoje uma importância muito grande para explicar a gênese e o desenvolvimento da inteligência no ser humano.

Seus estudos incidiram sobre a forma como se constrói o conhecimento a partir das estruturas cognitivas e afetivas dos indivíduos, em estádios de desenvolvimento, com uma sucessão previsível. Já a teoria de Ausubel focaliza a aprendizagem cognitiva ou mais especificamente aprendizagem significativa, pode-se dizer a aprendizagem verbal significativa receptiva. Ausubel considera a linguagem como um importante facilitador da aprendizagem significativa. O significado emerge quando é estabelecida uma relação entre entidade e o signo verbal que ela representa. Trata de uma teoria com forte relevância no contexto da educação. Neste contexto, o que se concebe é que ainda há divergências entre as teorias aplicadas e as avaliações realizadas, o que pode ou não comprometer os resultados no processo ensino aprendizagem.

Os resultados dos docentes quando associaram as alternativas e respectivos teóricos com seu perfil docente, apresentaram os traços do teórico Skinner evidenciados em maiores indicações pelos docentes tem-se que a ideia é de que o ensino jurídico deve dar-se conta de que não pode construir-se como prática exatamente para dar continuidade a estes processos dominantes da linguagem que consagram condições implícitas de um sistema de exclusão social e de desigualdades.

O que para Kretschmann; Ohlweiler (2014) refletem quanto em que o curso de direito tem contribuído para a formação de um profissional com perfil nos novos paradigmas. Onde Streck (2004 apud Kretschmann \& Ohlweiler, 2014, p. 274) tece severas considerações onde o sentido jurídico está na própria lei, onde o discente deve se apropriar de conceitos formulados pela ciência jurídica, o que para os autores traz "(...) consequências danosas para o futuro profissional do Direito, por formar operadores com baixa capacidade de compreender as divergências jurídicas do mundo, da vida e o conjunto das práticas socais que alimentam este campo do conhecimento".

Os docentes ainda acentuam uma característica de Skinner quando aplicam o condicionamento educacional, como forma de fixar esse processo de abstração da história, pois se cria um imaginário segundo o qual a reflexo sobre os processos da história é dispensável, afinal a programação tecnológica determina o porvir dos estudantes (Warat, 1995).

Em segundo plano apresentam traços do teórico Vygotsky o qual alude a importância de perceber que as pessoas partilham determinados conceitos e isto ocorre em virtude de haver interpretações diferentes destas práticas e se o professor, qualificado ou não, se mantém desconectado da realidade social, obviamente nada mudará no ensino e muito menos na educação jurídica (Kretschmann; Ohlweiler, 2014). Percebe-se que quando organizado os resultados por teórico, muda os valores, prevalecendo um perfil calcado em Skinner e Vygotsky. 
Quando aglutinadas as alternativas indicadas pelos docentes muda o perfil ficando empate entre Skinner e Vygotsky, ou seja, um educador detentor do conhecimento e que promove o repasse de conteúdos e ao mesmo tempo àquele que acredita que a interação do homem com o objeto e meio interferem na construção do conhecimento. 0 que leva a compreender que ainda esteja arraigado um misto da educação tradicional e da escola nova. Configurando assim uma contradição discutida por Saviani (1983) quando reforça que embora os professores tenham em mente o movimento da escola nova, ainda atuam na racionalidade e no tradicionalismo.

\section{CONCLUSÕES}

Ao concluir as discussões quanto ao domínio teórico-prático das teorias psicopedagógicas de aprendizagem presentes no discurso dos docentes do curso de direito do Campus Francisco Ferreira Mendes UNEMAT registra-se marcantes divergências entre os discursos docentes e as teorias, não havendo concordância entre os indicadores para determinada teoria, se contradizendo mesmo nos discursos, onde relatam perfil cognitivista com acentuada incidência em Skinner ou em Rogers.

Estas divergências associadas ao perfil docente previamente traçado deixam a transparecer que em se tratando de bacharéis em sua maioria desprovidos de curso em nível stricto sensu possa ser uma das causas do desconhecimento das teorias psicopedagógica, ou ainda a ausência de efetividade na carreira docente acrescido ao pouco tempo de atuação podem interferir significativamente quanto ao conhecimento científico das teorias e sua aplicabilidade no contexto pedagógico.

\section{REFERÊNCIAS}

[1] Almeida, Maria Isabel de Almeida. Formação do professor do Ensino Superior desafios e políticas institucionais. 1ํㅡㄹ. ed. São Paulo: Cortez, 2012.

[2] Faria, Maria Anastácia Teodoro de. Competência do Professor Universitário. Disponível em: Acesso em 16 de março de 2017.

[3] França, C.; Neves, I. S. V. Instituição de Ensino no Superior- o contexto real e a formação docente que neste espaço atual. Revista Acadêmica Senac Online, Edição no 1 out. Nov. dez, 2006. Disponível em: Acesso em maio de 2015.

[4] Franco, Gislaine Maria Lente. Campus Universitário Francisco Ferreira Mendes, Unemat Diamantino - MT: Infraestrutura para o Curso de Educação Física. Barra do Bugres: Unemat, 2015. 190 p. Kretschmann, Angela; Ohlweiler, Leonel Pires. 0 ensino jurídico entre condicionamento e criatividade: Desafios para Educação. Revista Diálogos do Direito v.4, n.6, jul/2014.

[5] Lima, V. V. Espiral construtivista: uma metodologia ativa de ensino-aprendizagem. Comunicação saúde educação, v. 21, n. 61, p. 412-434. 2017.

[6] Michavila, F. Soplanvientos de câmbios universitários. Em Boletín de La Red Estatal de Docência Universitária, 2000, p. 4-7.

[7] Oliveira, Daniele Vasconcellos de. Inserção da Iniciação à educação científica e tecnológica no curso de engenharia da produção: ferramenta para a formação do profissional-pesquisador. Tese apresentada ao Programa de Postgrado em Ciências de la Educación da Universidad Evangélica del Paraguay. Asuncion Paraguay. Jan.1994.

[8] Pimenta, Selma; Anastasiou, Léa G. C. Docência no ensino superior. Coleção Docência em formação, 5. ed. São Paulo: Cortez, 2014.

[9] Rauber, P. Educação Superior: desafios e limites postos pelo processo de internacionalização. In: Metodologia do Ensino Superior. Dourados: Unigran, 2008, p. 87-101.

[10] Silva, Adriene Sttéfane. Teorias da Aprendizagem na Ead ideações de professores autores de material didático impresso. Uberlândia- Minas Gerais. 2017.

[11] Silva, Edna Lúcia da; Menezes, Estera Muskat. Metodologia da Pesquisa e Elaboração de Dissertação 4a edição. Universidade Federal de Santa Catarina UFSC Florianópolis 2005.

[12] Warat, Luiz Alberto. Introdução Geral ao Direito II. Porto Alegre: Sérgio Fabris, 1995. 


\section{Capítulo 18}

A implantação da educação escolar na Estância Turística de Ouro Preto do Oeste - RO: Seleção e capacitação docente (1970 - 1980)

\section{Devanir Aparecido dos Santos}

\section{Ludimilla de Souza Colodetti}

Resumo: 0 presente artigo aborda a implantação da educação escolar na Estância Turística de Ouro Preto do Oeste - RO. 0 recorte temporal está delimitado às décadas de 70 e 80. Analisa-se os critérios de seleção e contratação dos professores, que na sua maioria não possuía nem mesmo o Ensino Fundamental completo. Para a realização da pesquisa balizou-se pelo método de abordagem qualitativo e pelo método de procedimento histórico. Nesse sentido, pela natureza da proposta, utilizou-se da História Oral para analisar as memórias e reminiscências dos professores que atuaram naquele período. Como técnica de pesquisa recorreu-se ao arquivo do GEPHEM-OPO (Grupo de Pesquisa e História da Educação e Memória de Ouro Preto do Oeste). 0 GEPHEM-OPO possui sala própria no prédio da UNEOURO (Faculdade de Ouro Preto do Oeste), onde estavam armazenadas as entrevistas. Também fez-se necessário realizar leituras em bibliografias sobre a história do Estado de Rondônia e a formação dos seus municípios.

Palavras-chave: Colonização, Educação escolar, Profissão docente, História Oral. 


\section{INTRODUÇÃO}

A Estância Turística de Ouro Preto do Oeste, situada no Estado de Rondônia, surgiu no final dos anos 60 e início dos anos 70 como um pequeno povoado denominado Vila de Ouro Preto, com apenas 500 famílias assentadas através do PICOP (Projeto Integrado de Colonização Ouro Preto), realizado pelo IBRA (Instituto Brasileiro de Reforma Agrária). O IBRA foi transformado, mais tarde, em INCRA (Instituto Nacional de Colonização e Reforma Agrária). Logo, a vila recebeu um contingente maior e assentou mais de 3 mil famílias. Pois, com a criação do projeto de colonização fez-se necessária a oferta de serviços básicos para a população, dentre esses serviços a educação escolar.

É comum perceber nos períodos e circunstâncias como o do recorte proposto, a educação escolar ser oferecida para a população em locais improvisados e por professores sem formação adequada para exercerem a função docente. Pois, com apenas a $4^{a}$ série, nestes casos, um indivíduo já poderia ser convidado para lecionar. $\mathrm{Na}$ atualidade, os(as) docentes que atuaram nas décadas de 70 e 80, já estão com a idade avançada e suas experiências vividas correm o risco de não serem conhecidas se não forem registradas. Objetiva-se então, com essa análise, contribuir para que a comunidade acadêmica e demais interessados possam conhecer um pouco mais, a partir das memórias de quem as experienciou o momento histórico proposto pelo recorte temporal, como se deu o processo de implantação da educação escolar, a admissão de docentes e a capacitação para a execução das atividades educacionais.

Pensa-se ser importante ressaltar, devido à natureza desta pesquisa, ou seja, fundamenta-se na História Oral, que a memória é algo íntimo de cada indivíduo, assim cada um reage de uma forma diferente ao relembrar reminiscências e experiências vivenciadas em grupos ou individualmente. Compreende-se que as lembranças de cada professor que atuou na época, e colaborou com essa pesquisa, pois estão arquivadas na memória, algumas provavelmente foram esquecidas, outras reavivadas e incrementadas, contudo as rememorações expostas nas entrevistas ofereceram um arcabouço de informações preciosas que resultaram na análise de como se deu o processo de escolarização dos alunos daquele período.

\section{MATERIAIS E MÉTODOS}

Recorreu-se a História Oral como método de análise. Isso ocorreu por meio de entrevistas realizadas pelo GEPHEM-OPO (Grupo de Pesquisa e História da Educação e Memória de Ouro Preto do Oeste), com os professores que lecionaram na época. Todo o material das entrevistas utilizado, neste trabalho, encontrase depositado na sala do referido grupo de pesquisa, na UNEOURO (Faculdade de Ouro Preto do Oeste). Percebe-se aqui então o uso da memória, conforme Neves (1998, apud DELGADO, 2003, p. 18):

O conceito de memória é crucial porque na memória se cruzam passado, presente e futuro; temporalidades e espacialidades; monumentalização e documentação; dimensões materiais e simbólicas; identidades e projetos. É crucial porque na memória se entrecruzam a lembrança e o esquecimento; o pessoal e o coletivo; o indivíduo e a sociedade, o público e o privado; o sagrado e o profano. Crucial porque na memória se entrelaçam registro e invenção; fidelidade e mobilidade; dado e construção; história e ficção; revelação e ocultação.

A memória é como um enorme arquivo repleto de gavetas que desempenha a função de guardar todas as informações consideradas relevantes, do passado e presente, para o indivíduo, como sua identidade, planos que objetiva realizar, lembranças de momentos particulares e com grupos sociais dentre muitos outros pontos aferidos ao ato de memorar.

Contudo se for analisar com profundidade a ação do recordar, chegar-se-ia a conclusão de que a memória particular de cada indivíduo está inteiramente ligada a memória coletiva, ou seja, ele utiliza-se de meios colocados pela sociedade para poder recordar seu próprio passado. Segundo Halbwachs (1990, p. 36):

Ela não está inteiramente isolada e fechada. Um homem, para evocar seu próprio passado, tem freqüentemente necessidade de fazer apelo às lembranças dos outros. Ele se reporta a pontos de referência que existem fora dele, e que são fixados pela sociedade. Mais ainda, o funcionamento da memória individual não é possível sem esses instrumentos que são as palavras e as idéias, que o indivíduo não inventou e que emprestou de seu meio. Não é menos verdade que não nos lembramos senão do que vimos, fizemos, sentimos, pensamos num 
momento do tempo, isto é, que nossa memória não se confunde com a dos outros. Ela é limitada muito estreitamente no espaço e no tempo.

0 autor sugere que o indivíduo não pode ter uma memória individual sem a presença da memória coletiva até certo ponto, ou seja, em relação ao uso de ferramentas exteriores ao indivíduo, percebível quando ele revive suas lembranças e fazem necessárias as memórias dos outros como o uso de vocábulos, conceitos, tais instrumentos que vieram antes dele, apreendidos através do meio em que se encontra. Contudo, a memória individual separa-se da coletiva quando o indivíduo reproduz em sua mente lembranças de algo que viu, fez ou até mesmo sentiu, esses acontecimentos experienciados pelo indivíduo não pertencem à memória coletiva, pois são subjetivos e individuais, possível motivo em que o autor afirma ser limitada dentro do espaço e tempo.

Também é necessário atentar para a oralidade que está interligada diretamente à memória, só que esta caracteriza-se pela articulação da fala, momento que o indivíduo compartilha suas lembranças com outros, a fim de preservar seu espólio identitário e reminiscências. Na concepção de Delgado (2003, p. 22.), na oralidade:

[...] deixam fluir as palavras na tessitura de um enredo que inclui lembranças, registros, observações, silêncios análises, emoções, reflexões, testemunhos. São eles sujeitos de visão única, singular, porém integrada aos quadros sociais da memória e da complexa trama da vida. A história oral é uma metodologia primorosa voltada à produção de narrativas como fontes do conhecimento, mas principalmente do saber.

Constata-se que a oralidade, na ótica da autora, baseia-se na iniciativa de contar um caso ou experiência verídica que implica nas lembranças, nos registros, nos sentimentos dentre outros de cada indivíduo, quer sejam individuais ou coletivas como já vimos anteriormente.

Porém, deve-se observar o dito e o não dito em um depoimento. Segundo Pollak (1989, p. 13):

Em todas as entrevistas sucessivas - no caso de histórias de vida de longa duração- em que a mesma pessoa volta várias vezes a um número restrito de acontecimentos (seja por sua própria iniciativa, seja provocada pelo entrevistador), esse fenômeno pode ser constatado até na entonação. A despeito de variações importantes, encontra-se um núcleo resistente, um fio condutor, uma espécie de let · motiv em cada história de vida. Essas características de todas as histórias de vida sugerem que estas últimas devem ser consideradas como instrumentos de reconstrução da identidade, e não apenas como relato, factuais.

Para o autor, o entrevistado tenta contar sua história a partir dos acontecimentos mais marcantes e que provavelmente influenciaram em várias tomadas de decisões que ocorreram durante sua existência. 0 que consiste na sua atual condição. De fato, isso tem um caráter acentuado para o narrador, justifica-se então o porquê das respectivas voltas aos mesmos fatos.

Na perspectiva inicial, acerca da discussão do não dito, dentro da oralidade, durante uma entrevista, o sujeito ouvido pode deixar de relatar lembranças por ter se esquecido devido ao tempo decorrido, ligado ao fato de que as pessoas não possuem o hábito de exercitar a rememoração, como já observado anteriormente. Ainda pode acontecer por ter vivido um acontecimento traumático que não será reportado, não por que o sujeito não quer falar sobre o evento, mas devido a algum tipo de bloqueio. Sobre isso, Pollak (1989, p. 13), enfatiza:

Pode-se imaginar, para aqueles e aquelas cuja vida foi marcada por múltiplas rupturas e traumatismos, a dificuldade colocada por esse trabalho de construção de uma coerência e de uma continuidade de sua própria história. Assim como as memórias coletivas e a ordem social que elas contribuem para constituir, a memória individual resulta da gestão de um equilíbrio precário, de um sem-número de contradições e de tensões. [...]. Assim as dificuldades e bloqueios que eventualmente surgiram ao longo de uma entrevista só raramente resultavam de brancos da memória ou de esquecimento, mas de uma reflexão sobre a própria utilidade de falar e transmitir seu passado.

O autor chama atenção para o fato de bloqueios que geralmente ocorrem em entrevistas. Para o autor, raramente são atribuídos a brancos ou blecaute que acontecem durante a recordação. Acredita-se que o 
entrevistado ao evocar seu passado faça uma reflexão a respeito dos eventos traumáticos. Como afirma Pollak (1989, p.14), "É como se esse sofrimento extremo exigisse uma ancoragem numa memória geral, a da humanidade, uma memória que não dispõe nem de porta-voz nem de pessoal de enquadramento adequado". É como se o entrevistado analisasse em algum momento se é mesmo necessário reportar tal evento e reviver um sofrimento apenas para que se possa produzir conhecimentos, dos quais a maioria das pessoas verão com insensibilidade e como algo corriqueiro.

\section{RESULTADOS E DISCUSSÕES}

\subsection{ANÁLISE DOS CRITÉRIOS ESTABELECIDOS NA ÉPOCA PARA CONTRATAÇÃO DOS PROFESSORES}

Conforme mencionado anteriormente, a Estância Turística de Ouro Preto do Oeste situada no Estado de Rondônia surgiu no final dos anos 60 e início de 70 como um pequeno povoado denominado Vila de Ouro Preto. Contava, a princípio, com apenas 500 famílias assentadas através do PICOP (Projeto Integrado de Colonização Ouro Preto) realizado pelo IBRA (Instituto Brasileiro de Reforma Agrária) atual INCRA. ${ }^{10}$ A Vila de Ouro Preto passou a receber muitos migrantes vindo de várias regiões do Brasil e logo precisou aumentar o número de assentados, estima-se mais de 3 mil famílias.

Com a criação do projeto de colonização fez-se necessária a oferta de serviços básicos para a população, dentre esses serviços a educação escolar, tema principal a ser abordado dentro do espaço e recorte de tempo proposto. A necessidade de fornecer educação para o povo ouro-pretense foi o gatilho para desencadear o desenvolvimento de escolas improvisadas tanto na zona rural quanto na zona urbana. Obviamente as escolas da zona urbana eram mais organizadas em vista das da zona rural.

A reflexão que segue trata sobre como os professores eram selecionados para o trabalho docente. A educação escolar iniciou-se na Estância Turística de Ouro Preto do Oeste entre 1970 e 1971, momento em que a Vila de Ouro Preto, como assim era conhecida, recebia inúmeros habitantes durante o processo colonizador. De acordo com Lopes et al (2015, p.7).

De 1970 a 1980, com os projetos implantados pelo Instituto Nacional de Colonização e Reforma Agrária (INCRA), quando contingentes populacionais provenientes das regiões Sul, Sudeste e Centro-Oeste do Brasil deslocaram-se para a região, período em que os professores eram recrutados entre as esposas ou filhas dos colonos que soubessem ler e escrever.

Muitos professores que atuaram no início da implantação escolar na Estância Turística de Ouro Preto do Oeste eram escolhidos conforme o grau de escolarização, ou seja, uma comunidade rural ou urbana que possuía uma quantidade significativa de alunos para fundar uma escola, a SEMECE, convidava uma pessoa da própria comunidade, que detinha grau de escolarização superior aos dos demais, para dar aulas.

A professora Maria da Luz (14/03/2015) iniciou a carreira docente em Rondônia entre 1971 e 1972 em JiParaná, com apenas a 4ạ série concluída, posteriormente mudou-se para a Vila Ouro Preto, no final de 1972 e início do ano de 1973 para lecionar na Escola Disneylândia, em entrevista sobre sua trajetória, na educação, forneceu alguns dados para a compreensão dos critérios utilizados na seleção dos professores:

[...] os primeiros professores aqui do Estado de Rondônia, que é antigo Território. Ninguém feis concurso, era assim, chegava num lugar. Ah! Não tem escola, vamos fundar escola. Tem tantos alunos? Tem. Então escolhia ali né? Na comunidade que já formava Igreja e escola mesma coisa né? Então convidava alguém que tinha $3^{\underline{a}}$ série, 4⿳亠丷a série pra dar aula, sabia ler, sabia escrever, ensinar os outros. Ali já era professor. É assim né? Não tinha concurso. Nois então pessoal do Antigo Território de Rondônia não teve concurso e muitos também do Estado não te..., não foram concursado. Era como precisava tinha gente né?

É perceptível, de acordo com o relato da fonte citada acima, que na década de 70 era mais cômodo para o órgão que detinha o controle da contratação de pessoal pegar alguém que possuía um nível mais elevado dentre os demais nas comunidades, e colocar para alfabetizar aos alunos. A maioria dos professores eram

10 Para maiores informações ler Teixeira, Marco Antônio Domingues. História Regional: Rondônia, Marco Antônio Domingues Teixeira, Dante Ribeiro da Fonseca, PV, RO, 2001. 2ª Ed. cap.11. Outra leitura importante é IBGE (Instituto $\begin{array}{lllll}\text { Brasileiro de } & \text { Geografia } & \text { Estatística). } & \text { Disponível } & \text { em: }\end{array}$ https://cidades.ibge.gov.br/painel/historico.php?codmun=110015 
selecionados dentro da localidade, ou comunidade, onde seria criada uma escola, sem levar em consideração, muitas vezes, alguns fatores como condições de trabalho e de transporte.

A professora Cleusa Silvério da Silva (29/03/2015), que chegou no Estado de Rondônia em 1971 sublinha em entrevista alguns destes pontos:

[..] Quando eu comecei que eu falei pra você... quando eu comecei ontem um... quando eu comecei em 71 que eu cheguei a Rondônia ai em 75 é começaram a quere fundar escolas num... na... rurais, na... escolas no sitio. Aí saiu procurando, buscando as pessoas que tinha um pouquinho mais de estudo pra pode é... desenvolver esse trabalho. Nessa época eu era professora leiga. Eu tinha só a $8^{\mathbf{a}}$ série incompleto, aí eis já me arrastaram e já fui né?

Aqui, a professora Cleusa apresenta em sua fala, alguns lapsos e bloqueios de memória, Bobbio (1997 apud DELGADO, 2003, p. 16) esclarece que isso ocorre porque:

0 relembrar é uma atividade mental que não exercitamos com frequência por que é desgastante ou embaraçosa. Mas é uma atividade salutar. Na rememoração reencontramos a nós mesmos e a nossa identidade, não obstante muitos anos transcorridos, os mil fatos vividos.

Assim, neste primeiro momento a professora sentiu dificuldade em expor recordações vividas há muito tempo, porém ao falar sobre seu passado, abriu-se uma porta para que as lembranças adormecidas fossem ressurgindo, porém no transcorrer da entrevista houve alguns brancos, momento em que ela estava reorganizando as memórias na ordem cronológica dos fatos.

Nesse sentido, Pollak (1989, p. 13), também afirma que “[...] Ao contarmos nossa vida, em geral tentamos estabelecer uma certa coerência por meio de laços lógicos entre acontecimentos chaves [...], e de uma continuidade, resultante da ordenação cronológica".

De acordo com as informações dos entrevistados pode-se deduzir que a SEMECE contratava mão de obra sem qualificação adequada para alfabetizar a população, devido à escassez de pessoas formadas para assumir as salas de aula. Isso fica evidenciado no testemunho da professora Gisele Vicente Campos (30/03/2015), que atuou também na década de 70:

[...] eu fui convidada para ser professora não porque eu pretende-se algo. Porque eu só tinha a $8^{\text {o }}$ série, mais porque precisavam dos meus préstimos. Porque naquele tempo lá nos... na década de 70 quem tinha $4 \stackrel{a}{a}$ série e primário já poderia ser professora aqui porque tava ensinando, alfabetizando as crianças que necessitavam pra poder ajudar os pais na leitura da... de adquirir os documentos das suas terras, isso era importante, saber ler e escrever. Então eles é... me requisitaram para trabalhar como professora, então foi assim um pedido muito especial para trabalhar [...]

A fala da professora Gisele reafirma o dilema em que a SEMECE se encontrava, pois, havia a necessidade de oferecer a educação escolar aos moradores das comunidades, porém faltava mão de obra especializada. A solução mais viável que encontraram no momento foi essa, como está explícito nos testemunhos das fontes acima, ou seja, buscar aqueles ou aquelas que detinham o grau escolar mais elevado dentre os outros para começar o trabalho de alfabetização.

Na década de 80 o critério de seleção persistia quase inalterável, havia muita semelhança aos critérios utilizados na década anterior, pessoas com $2^{\circ}$ grau incompleto eram efetivadas, o que conferia às mesmas a responsabilidade de alfabetizar os demais, o professor Manoel Mariano Neto (06/02/2015), trabalhou na educação no município durante o período de 1983 até 1987, ao ser entrevistado relatou como ocorria a seleção:

[..] naquela época eu nem sequer tinha o $2^{2}$ grau. Então é... E, era uma época onde eis tinha muita, muita, muita falta de profissional. Então é.... Eles só faziam um teste a nível de $1^{1}$ grau né? Acho que nem era $1^{\circ}$ grau, acho que nível de $4 \underline{a}$ série mesmo. Fazia o teste na SEMECE e logo já era contratado. Agora depois quem era contratado é... tinha é... curso de... de especialização em $2^{\circ}$ grau que era chamado de Logos II [...] ele é a nível de 5o ao $2^{\circ}$ grau [..].

Baseado nos relatos do professor, percebe-se que não houve grandes mudanças na forma de selecionar os professores desde o final de 1972 até a década de 80. A fala do professor Manoel chama atenção para um 
fato não percebível nos critérios de seleção daquele período. Segundo relata, os professores da década de 80 faziam um teste, uma prova na SEMECE, para confirmar as aptidões que se esperava que os candidatos detivessem. Após o processo eram selecionados aqueles que possuíam maior capacidade para desenvolver o trabalho.

Os professores que iniciaram a carreira docente na da década de 70 não mencionaram esse critério durante as entrevistas, pode-se compreender que isso ocorreu porque não havia esse método de escolha na época ou porque passou-se muitos anos e essas recordações não vieram à tona no momento da entrevista, como Bobbio (1997, apud DELGADO, 2003, p. 16), esclareceu anteriormente acerca da importância de se relembrar o passado.

Apesar das dificuldades encontradas na época, houve mudanças, porém muito discretas acerca da valorização dos professores, quando se compara o final da década de 70 com o início da década de 90 . É correto afirmar que os professores, na sua grande maioria, eram contratados sem formação devido à necessidade de alfabetizar a população das comunidades recém-formadas e pela falta de profissionais especializados. Porém, o Governo a partir da contratação dos mesmos, preocupou-se e promoveu programas de formação continuada.

Esses programas são o Logos I e II, Projeto Fênix e bem mais tarde o PROHACAP, assim que o professor era efetivado o Governo disponibilizava esses cursos para que pudessem se especializar. Aqueles que possuíam somente até a $4^{\underline{a}}$ série realizavam o Logos I que os habilitava até a $8^{\underline{a}}$, ou seja, o $1^{\underline{0}}$ grau completo. Nesse sentido é que afirma a professora Maria da Luz (14/03/2015):

Quando eu comecei da aula eu só tinha 4⿳a a série, só a 4⿳ạa série [...] Aí depois veio o projeto é... Logos I. É projeto por que? Porque é pra vê se dá certo né? Então primeiro teve o projeto Logos I [...] E esse projeto Logos I era para habilitar o professor até a $8^{\underline{a}}$ série, quer dizer pra ter o $1^{\text {o }}$ grau completo ai nois fizemos[...].

0 projeto Logos II, embora habilitasse para o $2^{\circ}$ grau, poderia ser realizado por professores que tinham apenas a $3^{\underline{a}}$ e $4^{\underline{a}}$ série e não somente os que fizeram o Logos I, que teriam no caso o $1^{\circ}$ grau. Então, a diferença entre o Logos I e o Logos II é que o Logos I conferia o nível de 1o grau enquanto o Logos II conferia o nível escolar de $2^{\circ}$ grau. Segundo Lopes et al $(2015$, p.7, 8), “[...] após a fundação do município, com a Lei no 6.921 de 16/06/1981, estabelece o Logus I e II e o Projeto Fênix, modalidade semipresencial onde os professores leigos tiveram a oportunidade de estudar na sede do município".

Outro programa que merece ser lembrado é o PROHACAP (Programa de Habilitação e Capacitação de Professores Leigos), sendo que o mesmo foi instalado e funcionou entre 2000 e 2009. Oferecia-se, por meio desse curso, licenciaturas para que os professores leigos, que possuíam apenas o curso médio do Magistério pudessem fazer o Ensino Superior. Foi possível perceber através da criação desses projetos o interesse do governo em promover a formação desses professores que iniciaram a atividade docente como leigos e que hoje a grande maioria é licenciada em alguma área do ensino.

\section{CONSIDERAÇÕES FINAIS}

A análise apresentada, no trabalho, fundamentou-se teoricamente nos pressupostos basilares da História Oral e procurou apresentar resultados que correspondam ao que se espera de uma pesquisa dessa natureza. Nesse sentido pode-se afirmar que, na década de 70, os professores contratados, na grande maioria, possuíam apenas a $4^{\underline{a}}$ série do ensino fundamental, às vezes até incompleto, ou seja, aqueles que "sabiam" ler e escrever eram efetivados para ensinar aos demais. Em cada comunidade escolhia-se um ou dois, pois era mais fácil para esses professores trabalharem em sua própria comunidade.

Pode-se considerar ainda que o oferecimento de serviços públicos, mais especificamente a educação, no início da colonização da Estância Turística de Ouro Preto do Oeste - RO, foi se desenvolvendo como que no improviso, utilizando-se da mão de obra que existia à disposição naquele momento. Não significa que essa mão de obra era qualificada, longe de ser, porém era a que se podia contar para a execução dos trabalhos educacionais. Com o desenvolvimento da região e do município, com o passar do tempo, desenvolveu-se programas de formação e capacitação docente para atender as necessidades escolares.

Em suma, os resultados apresentados, nesta reflexão, fazem entender que a forma da implantação da educação escolar na Estância Turística de Ouro Preto do Oeste não é um fato isolado quando se analisa o contexto da colonização do Estado de Rondônia, bem como a oferta dos serviços públicos nestas novas frentes de colonização dos anos 70 e 80, que formaram muitos dos atuais municípios rondonienses. 


\section{REFERÊNCIAS}

[1] Bergson, Henri, 1859-1941. Matéria e memória: ensaio sobre o corpo com o espirito/Henri Bergson; tradução Paulo Neves. - 2 - ed. - São Paulo: Martins Fontes, 1990. - (Coleção tópicos).

[2] Bobbio, Noberto. O Tempo da memória. Rio de Janeiro: Campus, 1997.

[3] Delgado, Lucilia de Almeida Neves. História oral e narrativa: tempo, memória e identidades, 6, 2003. VI Encontro Nacional de História Oral (ABHO) - Conferência de Abertura: Professora Titular de Metodologia da História da Pontifícia Universidade Católica de Minas Gerais. Ex-presidente da Associação Brasileira de História Oral.

[4] Halbwachs, Maurice. A memória coletiva. Ed: Revista Dos Tribunais LTDA. Rua Conde do Pinhal, 78, SP. ed: 1990.

[5] Ibge (Instituto Brasileiro de Geografia e Estatística). Cidades. Disponível em: Https://cidades.ibge.gov.br/painel/historico.php?codmun=110015 Acesso em: 10/06/2017.

[6] Lakatos, Eva Maria. Sociologia geral I. Eva Maria Lakatos, Marina de Andrade Marconi, colaboradora. - 6. ed. rev. e ampl. - São Paulo: Atlas, 1990.

[7] Lopes, Ivone Goulart. [et tal]. O Fio Da História - Nas Trilhas de Ouro Preto do Oeste-Ro. Vitrais da Memória de Professores e Escolas. In. XI Seminario Internacional de La Red Estrado - ISSN 2219-6854 Movimientos Pedagógicos y Trabajo Docente en tiempos de estandarización. México, 2016.

[8] Neves, Margarida de Souza. História e Memória: os jogos da memória. In: MATTOS, Ilmar Rohloff (org.). Ler e escrever para contar: documentação, historiografia e formação do historiador. Rio de Janeiro: Access, 1998.

[9] Pollak, Michael. Memória, Esquecimento, Silêncio. Tradução Dora Rocha Flauman. Estudos Históricos. Rio de Janeiro, vol, 2, n. 3, 1989, p. 13-15.

[10] Teixeira, Marco Antônio Domingues. História Regional: Rondônia, Marco Antônio Domingues Teixeira, Dante Ribeiro da Fonseca, PV, RO, 2ª Ed, 2001.

[11] Uneouro. Gephem-OPO (Grupo de Pesquisa e História da Educação e Memória de Ouro Preto do Oeste). Arquivos em vídeos. 2015. Professora Maria da luz (14/03/2015); Professora Cleusa Silvério da Silva (29/03/2015); Professora Gisele Vicente Campos (30/03/2015); Professor Manoel Mariano Neto (06/02/2015); Professor Antônio Ribeiro Rosa (22/03/2015); Professora Jolita Alves de Oliveira (14/03/2015); Professora Lourdes do Carmo Barbosa (01/04/2015); Professora Ivânia Maria Salvatori (02/03/201); Professora Emília Fagundes de Oliveira (02/032015). 


\section{Capítulo 19}

\section{"Civilizar" e integrar: Educação, política e ideologia na Província do Pará após a cabanagem}

\section{Denise de Souza Simões Rodrigues}

Resumo: Este artigo apresenta de modo restrito alguns resultados obtidos em pesquisa de longo alcance histórico, abrangendo desde a fase colonial até as décadas iniciais do período republicano, sobre a educação na Amazônia, buscando elucidar as conexões existentes entre a evolução histórica da educação no Pará e os movimentos sóciopolíticos-culturais e assim estabelecer a natureza ideológica de seus objetivos e procedimentos. Entre os objetivos da pesquisa realizada encontra-se a disposição de abordar a documentação com olhar crítico, com a clara intenção de estabelecer as dificuldades e limites da educação realizada no Pará no século XIX, sem esquecer sua inclusão no panorama nacional. 0 problema que norteou a pesquisa documental e bibliográfica intentou compreender como e de que forma se produzem e são legitimados os conteúdos educacionais e como se realizam as práticas educativas que em última análise formatam o sujeito histórico que nos interessa em particular - o paraense - em períodos históricos determinados pela emergência de movimentos sociais relevantes. Esse ponto nos remete ao processo de fabricação social dos indivíduos. Esta abordagem nos conduz desde o passado colonial, alcançando todo o período imperial e o alvorecer da república. Como a educação efetivamente contribui para a fabricação social desses indivíduos? Como e em que níveis se estabelecem conexões com os movimentos sociais? Os resultados obtidos e apresentados neste artigo, respeitando os limites do espaço disponível, envolvem as consequências de uma revolução - a Cabanagem - e o desvelar da nascente república ao final do século, como elementos importantes para a estruturação do social-histórico e a compreensão e análise da educação formal e informal. A intenção é ao mesmo tempo descrever o processo e elucidar as bases ideológicas que o sustentam e modelam a realidade vivida pelos atores sociais, professores e alunos, integrando-os em seu espaço político-cultural.

Palavras-chave: Educação formal. Ideologia. Movimento social. 


\section{DOUTORA EM SOCIOLOGIA PELA UNIVERSIDADE FEDERAL DO CEARÁ. PROFESSORA TITULAR DE SOCIOLOGIA DA UNIVERSIDADE DO ESTADO DO PARÁ (UEPA). PROFESSORA DO CURSO DE MESTRADO DO PPGED/CCSE/UEPA. LÍDER DO GRUPO DE PESQUISA SOCIEDADE, CIÊNCIA E IDEOLOGIA INTRODUÇÃO}

Durante a Regência do Império no Brasil ocorreram vários movimentos de contestação política, entre eles destaca-se a Cabanagem (1835-1840), por sua vinculação tão nítida quanto intensa e abrangente, com as classes subalternas e duramente oprimidas da sociedade. Este movimento revolucionário também conseguiu, em alguns momentos, seduzir e arrastar outras frações de classe como os pequenos proprietários, artesãos livres, assalariados ligados às diversas atividades mercantis e sacerdotes católicos.

As insurreições, as sedições do corpo de tropa, os atos de revolta e os violentos protestos populares, não eram fatos raros na Amazônia portuguesa. As dificuldades enfrentadas desde o primeiro momento pelos colonizadores em relação ao uso de mão-de-obra indígena foram a razão de inúmeros conflitos com as ordens religiosas, em especial com os missionários jesuítas. Em várias oportunidades, as hostilidades se traduziram em enfrentamento aberto, agressões e deportações. 0 que sempre esteve em questão foi o controle total da mão-de-obra indígena e as possibilidades de lucro que isso oferecia.

Ao final do século XVIII, a Amazônia não alcançou a prosperidade pretendida e prometida pela intervenção pombalina na administração do Estado do Grão-Pará. Sob a égide dos Diretórios ${ }^{1}$, a opressão aos índios aumentou, provocando fugas constantes e mortes prematuras, em razão das pesadas jornadas de trabalho e dos castigos corporais, usados de forma tão imoderada em sua intensidade quanto em sua frequência. Azevedo (1999) enfatiza que a demanda sempre crescente por escravos levava à necessidade de novos apresamentos, sempre mais difíceis, em face do rigor predatório dessas tropas de resgate, que levou ao extermínio a maioria das nações indígenas que habitavam a região.

Estagnada economicamente a Amazônia e em decadência os seus núcleos populacionais, um novo ordenamento das relações de trabalho é executado buscando o controle da força de trabalho sob condições mais rígidas de recrutamento dos índios considerados livres e a criação de aldeamentos especiais, e melhor explorar sua força de trabalho nas seguintes situações: Em unidades produtivas (estaleiros, roças e pesqueiros); Fazê-los trabalhar diretamente para particulares, com a promessa de pagamento de salários, promessa quase sempre esquecida; Empregá-los em obras públicas, sendo esta situação a mais temida por todos, pela brutalidade dos comandantes militares; Engajados como tropas auxiliares para diversos fins de defesa ou expedições arriscadas de novos resgates de índios nas matas.

Após os dois séculos de colonização a população de mestiços na Amazônia - os não brancos - oriundos das várias e sucessivas misturas entre brancos, negros e índios, que, embora livres, viviam como excluídos, na periferia das cidades e vilas, sujeitos ao arbítrio do poder dos governantes, temendo o recrutamento para o serviço nas tropas e nas obras públicas sob o jugo tirânico dos oficiais militares. E ao se iniciar o século XIX a situação social e econômica da população que habitava a Amazônia era caracterizada pela precariedade de recursos de toda ordem, opressão da maioria não branca e a apatia, o desinteresse, os horizontes limitados daqueles que exerciam o poder, fossem civis ou militares. Conforme Coelho (1993, p.93) afirma que:

A transformação das estruturas sociais e das relações de poder na Amazônia dar-se-ia através das conquistas da sua sociedade. Assim, entre 1820 e 1840, o tecido social da região conheceu a dissolução das bases que sustentaram o seu passado colonial e a organização das bases que modelariam a sua contemporaneidade.

As sedições e rebeldias da tropa se sucedem em ritmo acelerado questionando os limites da nova situação política. 0 excesso de autoritarismo e a insensibilidade política do comandante militar inglês contratado pelo Império brasileiro provocaram os trágicos acontecimentos que marcaram indelevelmente o momento em que os paraenses se proclamavam brasileiros.

A questão de quanto podem ser livres os cidadãos é tema que desde esse momento já se apresenta controverso. Senhores há muito tempo habituados a dispor dos indivíduos sem maiores considerações em relação às vontades individuais, numa região onde o controle sobre a força de trabalho significava possibilidades de riqueza e poder, não é difícil perceber quão problemática seria a extensão de direitos civis e políticos à grande maioria da população, mesmo se esses direitos estivessem situados muito mais no espaço abstrato das leis do que no exercício prático da vida cotidiana. 
A adesão do Pará à Independência representou para aqueles que há muito exerciam o poder a única possibilidade de mantê-lo. Os atos de repúdio e revolta que sofreram em várias cidades (especialmente grave foi à revolta em Cametá), após a morte brutal dos 255 presos nos porões do brigue Palhaço, atestam que seu domínio sobre a situação era precário, e seu autoritarismo intrínseco fatalmente acabaria produzindo perigosos confrontos, uma vez que as perseguições e injustiças continuavam sendo usadas como armas políticas contra desafetos particulares daqueles que exerciam o poder. Mesmo com a exoneração dos partidários de Portugal dos cargos da administração pública e após a anistia geral e absoluta concedida em 1824, os atos de rebeldia continuavam desafiando o poder da classe dirigente.

Tudo isso era agravado pela crônica situação de penúria dos cofres públicos, razão do atraso de meses no pagamento do soldo das tropas. A insatisfação e a indisciplina tornaram os quartéis fonte de atos frequentes de insubordinação e provocaram a rebelião dos efetivos militares da Capital. 0 resultado é o de sempre: violência, prisões e mortes. A revolução cabana consiste na expressão radical da rejeição popular ao domínio de uma classe identificada com o colonizador luso e que operava o sistema político de modo exclusivo e autoritário. Salles (1992, p. 66) sintetizou com precisão que "a Cabanagem devolve aos índios e mestiços, escravos e servos da gleba, a sua identidade perdida; é a guerra dos esfarrapados colonizados contra a minoria de colonos detentora do poder e dos meios de produção".

0 recrudescimento das ações de opressão sobre a população mestiça pobre e em alguns casos, sobre os frágeis estratos médios da sociedade, sempre tendo como pano de fundo a questões ligadas ao uso da força de trabalho, como bem representava o recrutamento obrigatório para o serviço militar, que atemorizava a todos, mesmo quando era oferecido sob a forma de policiamento civil.

0 risco em se armar cidadãos é idêntico em todas as partes, pode resultar em mais violência. Como o trabalho de policiamento voluntário é exercido sob liderança de um civil, que, apesar de receber patente militar, não está obrigado a obedecer ao código e à hierarquia do exército regular, a execução de funções paralelas de manutenção da ordem pública estimula as vaidades, as rivalidades e o favorecimento político de facções, provocando de imediato à necessidade de que os adversários também se organizem e se armem.

Quando a esse cenário se acrescenta um fato político relevante e desestabilizador do precário equilíbrio de forças, a abdicação de D. Pedro I, as perspectivas de um levante armado têm muito mais chances de se tornar realidade. 0 restabelecimento do equilíbrio vai depender de avaliações extremamente conjunturais, isto é, análises de curto prazo, no âmbito dos quais os atores envolvidos na luta pelo poder, certamente, não hesitarão em radicalizar o discurso e a práxis política, se visualizarem a possibilidade de obter a hegemonia, como aconteceu no decorrer do período cabano. A violência e o terror se estabelecem no cotidiano tornando as condições de existência muito precárias, incompatíveis com o planejamento necessário ao crescimento social, econômico e cultural. A vida fica em suspensão.

Ao se analisar a Cabanagem é possível perceber que a situação de contestação ao poder na Amazônia já se arrastava há mais de uma década, antes que a fase aguda da luta revolucionária se instalasse. Após esse período (1835-1840), a base produtiva da região foi profundamente afetada pela interrupção das atividades mais rentáveis e a consequente desorganização dos negócios como pelo extermínio de aproximadamente um terço de sua população economicamente ativa.

Criadas pelo Ato Adicional de 1834, as Assembleias Legislativas Provinciais tinham autonomia para legislar sobre a instrução pública primária e secundária e a criação e fiscalização de estabelecimentos educacionais públicos e particulares, e o governo central, através do Ministério do Império, assumia o controle de ambos os graus na Corte e do ensino superior em todo o país. Segundo Vechia (2006, p.82):

A instrução pública passou a ser, então, o reflexo da instabilidade política, da carência de recursos nas províncias e suas especificidades. Em algumas províncias foram criadas aulas avulsas, sem os requisitos exigidos, e em outras passou-se a esboçar tentativas de dar uma certa organicidade às aulas avulsas. Foram criados, então, alguns liceus, instituições surgidas pela influência cultural e educacional que a França exercia à época e voltadas para atender a classe mais abastada da população. Os primeiros foram os de Pernambuco, em 1826; o do Rio Grande do Norte, em 1835; e os da Paraíba e da Bahia, em 1836. 
No Pará, a convulsão política, social e a extrema desorganização econômica provocada pela Cabanagem, somente com o restabelecimento da normalidade institucional com a posse de Bernardo de Souza Franco na chefia do governo, então se voltariam a pensar os destinos da educação. Em sua primeira fala como governante Souza Franco lamenta o estado calamitoso da província, seja pela perda tão numerosa de vidas, como pelo impacto que a desordem, os saques e o abandono das atividades produtivas provocaram na vida da Província.

\section{ESBOÇO DE ESTRUTURAÇÃO DA EDUCAÇÃO NA PROVÍNCIA DO PARÁ APÓS A CABANAGEM}

A educação após o período revolucionário na Província do Pará foi estruturada pelas medidas tomadas pela Assembleia Legislativa Provincial e sancionadas pelo vice-presidente Bernardo de Souza Franco. Essas medidas se encontram detalhadas na Lei n.o 97, de 28 de junho de1841, que regula a instrução primária e secundária e cria o Liceu Paraense. Como bem assinalam os estudiosos da História da Educação no Brasil:

A situação do ensino secundário no Brasil nas primeiras décadas do século XIX era semelhante à apresentada na segunda metade do século XVIII, em termos de aulas-régias ofertadas. Com a ação do Marques de Pombal, se de um lado houve o desmantelamento de um sistema estruturado de ensino, por outro houve a quebra de monopólio das ideias dos jesuítas. No século XVIII, a mentalidade do ensino jesuítico ainda continuou permeando os estudos secundários, principalmente os ofertados nas aulas-régias, uma vez que a maioria dos professores havia estudado nos colégios jesuítas existentes no Brasil ou no Colégio das Artes e na Universidade de Coimbra, administrada pelos jesuítas. Porém, lentamente, as concepções que nortearam as reformas pombalinas foram se infiltrando no Brasil. (VECHIA, 2006, p.79)

Em suas disposições a Lei no 97 estabelece o ensino público em dois níveis: o primário e o secundário. 0 ensino primário é gratuito e extensivo a todos, homens e mulheres, e se encontra dividido em duas classes de estudos. Segundo Pará (1841, p. 51-59):

Classe 1. Leitura e Escripta ou Calligraphia, Principios d' Arithmetica com o perfeito conhecimento das quatro operações arithmetica em números inteiros, fraccionados, complexos e proporções; Gammatica da Lingua Nacional, e Elementos d'Orthographia. Classe 2. Principios da Moral Christã, e da Religião do Estado, Noções de Civilidade, Elementos Geraes de Geographia, Leitura da Constituição, e da Historia do Brazil. [...] Alem das materias das duas Classes do artigo antecedente ensinar-se-ha mais do sexo feminino o uso d'agulha de cozer, e de meia; o bordado, as regras de talhar e cozer os vestidos, e os mais misteres próprios da educação domestica.

0 governo se encarregará de fornecer todo o material necessário às classes, que serão empregados nas atividades escolares, tais como cadernos, lápis, borrachas, livros, lousa e giz. Determina também o método a ser empregado no ensino, o do Barão Degerando ${ }^{11}$. A Lei no 97 também se refere à criação e manutenção de escolas. A condição para a presença da escola pública em determinada vila ou povoação depende da existência efetiva de alunos matriculados e frequentando as aulas caso contrário elas serão transferidas para outros locais, e assim foi estipulado pela lei, de acordo com Pará (1841, p. 51-59):

Art.6. 0 Presidente da Provincia creará novas Escolas nos Lugares onde mais convier, dependendo sua definitiva fixação da Assembléa Legislativa. Art. 7. ${ }^{\circ}$ Toda a Escola que no decurso de dous annos consecutivos deixar de reunir dez Alumnos matriculados pelo menos, com freqüência effectiva, será transferida pelo Prezidente para outro lugar onde possa ser freqüentada por maior números d'Alumnos, dando de tudo parte à Assembleia

\footnotetext{
11 Para uma leitura mais aprofundada consultar: Bastos (1839) e Bastos (1999).
} 
O acesso à educação primária foi proposto como livre, mas havia os excluídos: os escravos e os portadores de doenças contagiosas. A preocupação em negar aos escravos o acesso à educação oferecendo-lhes ferramentas operacionais tem como suporte a preocupação com a manutenção da estrutura de exploração escravagista do trabalho. Quando se trata dos acometidos por doenças endêmicas e epidêmicas que assolavam as áreas urbanas e interioranas em geral, a preocupação era evitar o contágio, dadas as precárias condições de saúde e saneamento existentes então.

A expansão das escolas públicas de "ler, escrever, contar e crer" (GONDRA; SCHUELER, 2008, p.53), carrega consigo a ambição de elevar o padrão de civilização do país, e oferecer o esboço mais sistemático de uma educação voltada para a preparação da grande massa da população, capacitando-a em um aspecto fundamental, como força de trabalho. Sua ideia de modernidade era frágil, excludente e incipiente quando se analisa a preocupação de tentar elevar-se aos padrões de civilização da Europa de então.

A educação passou a ser considerada estratégica para a construção da nacionalidade e para o projeto de poder das elites dirigentes. 0 primeiro passo seria ampliar a quantidade de escolas existentes nas principais vilas e cidades da Província. 0 segundo, capacitar professores e oferecer-lhes um plano de carreira como servidores do Estado, controlando seu ofício, designações, prêmios e aposentadoria.

A educação assume claramente seu papel de aparelho ideológico capaz de formatar corações e mentes necessários ao projeto de poder dessa classe e a instrução primária ampla e gratuita, oferecia aos conservadores o instrumento ideal de "fabricar" ${ }^{12}$ o cidadão brasileiro, de acordo com os valores morais dessa classe, obtendo a disciplina da força de trabalho, fundamental ao pleno desenvolvimento do capitalismo.

Como esclarece Castoriadis (1992, p. 132) "para cima do monopólio da violência legítima, há o monopólio da palavra legítima; e este, por sua vez, é ordenado pelo monopólio da significação válida. 0 Dono da significação reina acima do Dono da violência". A ênfase na educação escolar atendia ao objetivo principal de substituir o uso da força e da violência na "civilização dos mais desfavorecidos". A violência revolucionária havia cobrado seu preço em vidas em seu período mais útil ao capitalismo e deixado em frangalhos à economia.

A submissão humilhante ao trabalho servil daqueles que sobreviveram ${ }^{13}$ não apresentando a produtividade esperada impeliu a elite a buscar maneiras mais eficazes de obter a submissão em caráter mais duradouro e sem custos altos de mão-de-obra tão necessária ao desenvolvimento econômico.

A oferta de educação básica aos pobres e órfãos desvalidos, muito semelhante ao que existia no período colonial, e enfatizando a aprendizagem de ofícios, se constituía então em prioridade. Para os afortunados membros das classes mais favorecidas pela posse de recursos econômicos e financeiros, seria oferecida a educação em modelos que atenderiam às necessidades de formação de pessoas para gerir e administrar as empresas públicas e privadas, assumir posições de mando político nos poderes constituídos ${ }^{14}$.

Portanto o ensino primário público era oferecido para todos, mantidas as exclusões de mencionadas anteriormente, trazia como apelo o internamento em instituições educacionais de meninas e meninos pobres para aprenderem ofícios. O ensino secundário oferecido no liceu, ao alcance dos estratos superiores, estava estruturado em dois cursos, o de Humanidades (5 anos) e o de Comércio (2 anos), sendo as principais matérias: Latim; Francês; Aritmética, Álgebra e Geometria; Filosofia Racional e Moral;

\footnotetext{
12 Esclarecendo o conceito de fabricação social dos indivíduos, retomo Castoriadis (1982, p.302): a fabricação dos indivíduos pela sociedade, a imposição aos sujeitos somato-psíquicos, ao longo de sua socialização, do legein, mas também de todo as atitudes, posturas, gestos, práticas, comportamentos, habilidades codificáveis é, evidentemente um teukhein, mediante o qual a sociedade faz serem estes sujeitos como indivíduos sociais, a partir dos dados somatopsíquicos, de maneira apropriada à vida, a sua vida nesta sociedade e com vistas ao lugar que nela ocuparão graças a isso, os indivíduos sociais são feitos, enquanto valendo como indivíduos e valendo para tal "papel", "função", "lugar" sociais.

13 O "processo de pacificação" imposto aos vencidos nos Corpos de Trabalho pelo governo legal de Soares D’Andréa, recrutava todos os homens válidos entre 10-50 anos, conduzindo à servidão a população mestiça. Essa medida não apresentou bons resultados pela resistência e/ou estratégias de sobrevivência oferecida pelos cativos, que se negavam às duras jornadas de trabalho (RAIOL, 1970; REIS, 1972; 1993).

14 Carvalho (1996, p.18) argumenta "que a adoção de uma solução monárquica no Brasil, a manutenção da unidade da ex-colônia e a construção de um governo civil estável foram em boa parte consequência do tipo de elite política existente à época da Independência, gerado pela política colonial portuguesa. Essa elite se caracterizava sobretudo pela homogeneidade ideológica e de treinamento. [...] essa homogeneidade era fornecida sobretudo pela socialização da elite, que será examinada por via da educação, da ocupação e da carreira política".
} 
História Universal, Geografia Antiga e Moderna, História do Brasil; Retórica, Crítica, Gramática Universal e Poética; Escrituração Mercantil e Contabilidade; Inglês. Assim surgiu o Liceu Paraense, nos moldes do Colégio Imperial Pedro II criado em 1837 e uma Escola Normal, que sem espaço próprio e adequado, se tornaria um curso anexo ao Liceu Paraense. Só algumas décadas depois e sua criação, o curso destinado à formação de professores ganharia prédio próprio.

\subsection{O OFÍCIO DE PROFESSOR: CARGOS, CARREIRA E REMUNERAÇÃO}

Ao final do século XVIII o Governador do Estado Grão-Pará e Maranhão, Francisco de Souza Coutinho, onde lamenta o estado triste e deplorável em que se achava a educação no Estado. Sua correspondência dirigida ao Primeiro Ministro Rodrigo de Sousa Coutinho faz um relato detalhado da situação de abandono, penúria e descaso que encontrou aqui na Amazônia. Seu relato certamente fundamentou a regulamentação que visava oferecer novos rumos para o desenvolvimento local a partir da educação da população ${ }^{15}$

Trata-se do Regimento Provisional para os Professores de Filosofia, Retórica, Gramática e de Primeiras Letras no Estado do Grão-Pará datado de dezoito de março de mil e oitocentos. Em sua introdução o documento faz um apanhado da situação em que se encontra a educação. Não havia um sistema organizado de disciplinas necessárias à instrução pública, a qualidade da instrução oferecida pelas mesmas era sofrível, e pouco atendia às necessidades locais.

0 documento menciona ainda a falta de uma norma fixa e princípios claros para a nomeação e escolha dos professores, além de ressaltar a necessidade de permanente inspeção das atividades realizadas pelos professores, em busca do cumprimento de suas obrigações com proficiência e zelo. Através dessa correspondência o rei determina que:

a) As escolas públicas serão abertas nas cidades, vilas e povoações;

b) A clientela: todos os súditos, de ambos os sexos;

c) Os níveis de ensino: 1) ler, escrever, contar e catecismo; 2) aulas de Retórica, Gramática, Filosofia, Aritmética, Geometria, Trigonometria, Latim e Grego;

d) Os objetivos: formar/habilitar pessoas para atuarem como contadores, geômetras e topógrafos, que serão úteis para demarcar sesmarias e fazerem planos e descrições de territórios e rios.

Esse documento assegura o pagamento dos professores, assim como cria um fundo para a aposentadoria dos mestres, que após longos anos de serviço estiverem impossibilitados de exercerem a profissão. Finalmente, pretende estimular e premiar anualmente os alunos com medalhas de valor (honra ao mérito) quando se destacarem em seus trabalhos finais, ou garantir a publicação de obra que mereça passar à posteridade.

No intuito de implantar em definitivo o sistema público de educação, a coroa portuguesa decidiu estabelecer regras detalhadas sobre todos os itens mencionados acima: a instrução a ser oferecida, a contratação de professores e discriminação de suas atividades docentes, os proventos a que fariam jus, as disciplinas e seus conteúdos a serem ensinados, enfim tratava-se de uma lei orgânica para o setor - 0 Regimento Provisional para os Professores ${ }^{16}$. Entre as muitas recomendações iniciais destacam-se: manter as cadeiras (aulas).

O Regimento Provisional teve alcance limitado em sua proposta de estruturação em razão da crise político-militar que obrigou a mudança da Corte para o Brasil e esse fato acarretou limitações econômicas e financeiras ainda maiores para a governabilidade do Estado do Grão-Pará. Logo a agitação política constitucionalista incendiaria os ânimos e as sublevações eram uma preocupação constante. Pouco foi feito pela educação nas primeiras décadas do século XIX. Não havia professores preparados suficientes nem na capital, e os pais não valorizavam a educação, muitas vezes impedindo seus filhos de estudarem por classificarem como inútil a atividade, tal a precariedade do que era ministrado e o atraso da mentalidade dos habitantes.

\footnotetext{
15 Consultar sobre o assunto: REIS (1972) e REIS (1993).

já existentes no Seminário (Filosofia, Retórica) e novamente estabelecer as aulas de ler, escrever e contar e doutrina cristã e "alguma de Gramática que se ensine boa latinidade".
}

${ }^{16}$ A partir de agora será mencionado como Regimento Provisional. 
Os anos de agitação política culminaram com a revolução cabana (1835-1840) que deixou um rastro impressionante de mortes e destruição. Com a legalidade restabelecida era chegado o momento de fazer o balanço dos problemas. E certamente a precariedade da educação assumia papel preponderante nessa análise. Havia que manter e criar escolas, e formar professores, estabelecer conteúdos e normas de conduta profissional e oferecer um plano de carreira profissional. E os governantes se sucedem com suas ideias e planejamentos basicamente inspirados no Regimento Provisional de 1800.

Basta um olhar panorâmico sobre a Lei no 97 de 28/06/1841 e verificar o que estabelece quanto à forma de recrutamento dos professores, quantos serão nomeados, a remuneração a que farão jus, as condições do exercício do magistério, as punições a que estão sujeitos diante da quebra das regras previstas na lei. ${ }^{17}$

Nesses dois documentos que legislam sobre a educação há o se poderia denominar de um esforço para a instituição de uma carreira docente e de acessibilidades a ela. Estão previstas também normas para o exercício profissional e as exigências intelectuais e morais para o ${ }^{8}$ Candidatos, o Prezidente as proverá interinamente em pessoas idoneas, e de reconhecida capacidade para o Magisterio cargo, e o controle previsto na lei sobre a vida pessoal do mestre é bastante exigente no que diz respeito aos valores morais e religiosos. Outro ponto que chama atenção é a preocupação em assegurar níveis diferenciados de salários de acordo com a atuação do professor nos dois níveis de ensino previstos na lei.

Ao oferecer a possibilidade de aposentadoria integral ou proporcional de acordo com o tempo de serviço e atuação na profissão ou estimulando a permanência no serviço daqueles que declinassem da aposentadoria prevista no tempo máximo (40 anos de serviço) mediante gratificação especial, essas leis são um claro sinal de modernidade e da mudança de perspectiva da elite dirigente quanto à importância dos mestres na obtenção dos resultados esperados da educação das crianças e dos jovens. Embora os salários não fossem elevados e com frequência sofressem atrasos, ainda assim considero uma expectativa de melhoria da condição de professor em relação ao abandono anterior.

Em uma sociedade em que o trabalho sofre a mácula da escravidão, procurar organizar, estimular uma profissão não contaminada como trabalho servil e de escravos, parece-me um pequeno sinal de avanço nas relações do mundo do trabalho, mesmo porque a centralização das decisões nas mãos do Governador ou de seu substituto imediato indica o autoritarismo que permeia as decisões sobre os concursos, permanência dos mais antigos que já se encontram na profissão ou a interinidade de muitos outros, diante da dificuldade de se ter pessoas preparadas para o exercício da profissão na Província. Controle de quem ensina, de quem aprende, do que é ensinado e como é ensinado.

Essa é a concepção conservadora do poder da elite dirigente: assegurar-se de que a médio e longo prazo a paz seria consensual e a tornar a contestação a sua hegemonia algo muito difícil de ser implementado.

\section{CONSIDERAÇÕES FINAIS}

A fundação de Belém no antigo Grão-Pará foi uma decisão da autoridade colonial tendo em vista as necessidades de defesa deste espaço diante da ameaça estrangeira já estabelecida no interior dos vales de alguns de seus rios mais importantes. A aliança que então se produziu entre a espada e a cruz, diz muito sobre o que foi a instituição de uma sociedade branca em meio à selva e seus habitantes nativos. E desde então é impossível desconectá-la dos objetivos estratégicos que sempre nortearam a ocupação e exploração do espaço amazônico.

A educação foi arma ideológica empregada para consolidar, conquistar efetivamente, o que a violência militar do administrador colonial se revelou incapaz de obter: a adesão ao sistema de dominação, possibilitando que o desafio constituído pela produção de súditos para Deus e a coroa, fosse vencido. A força-tarefa utilizada: os missionários. Com o emprego de uma violência mitigada, buscaram a adequação dos indivíduos em relação ao ofício ensinado, tendo em vista a estrutura produtiva, tudo isso redefinido pelos padrões de uma nova sociabilidade, cuidadosamente ensinada, especialmente às crianças de quem se esperava a continuidade da experiência evangelizadora.

\footnotetext{
17 Segundo Pará (1841) Art.14..$^{\circ}$ Haverá tantos Professores do Ensino Primario, quantos forem as respectivas Cadeiras, competindo a cada um a consignação annual de quatro centos mil réis, e o de ensino Normal o de seis centos mil réis.Art.15. ${ }^{\circ}$ Seráõ oito os Professores para as Cadeiras do Lycêo, os quais venceráõ o ordenado de seis centos mil reis cada um, e trez Substitutos (...) com o ordenado de quatrocentos mil reis.Art.16. ${ }^{\circ}$ E Emprego de Professor he vitalicio, e será provido em pessoas idoneas, e pela forma estabelecida no $\S 4 .^{\circ}$ Art. 22 desta Lei. Art.17. 0 Concurso das Cadeiras vagas de qualquer dos ensinos, será publicado pelo Director, e se depois de passado o prazo marcado não comparecerem
} 
Seu esforço educacional resultou naquilo que denomino de uma pedagogia da sujeição ou da submissão, uma prática educativa que combinava com sucesso o ensinar a ler, escrever e contar através da repetição exaustiva e/ou cantada das lições e o seu representar, em pequenos autos de fé e exaltação religiosa, mesclada de proibições, castigos e recompensas. Por outro lado, a criança ou o jovem era instruído em artes e ofícios essenciais aos propósitos da empresa colonial capitalista e desde cedo internalizava a obediência fundamental ao seu lugar na sociedade, fosse sob o domínio estrito do patrão religioso, civil ou militar.

Após a expulsão dos jesuítas e a implementação de um modelo embrionário de escola pública sob comando das autoridades coloniais militares e/ou civis, resultou prejuízo para o Grão-Pará. O projeto "civilizador" da coroa na Amazônia pensava a educação como fator integrador e nivelador de diferenças culturais, elemento importante para seus planos de desenvolvimento econômico e social da região.

Três décadas após, ao final do século XVIII, o fracasso das medidas preconizadas após a expulsão dos jesuítas era constatado pelas autoridades e novamente se imaginou um plano salvador que oferecesse uma sistematização das ações educativas, objetivando mudar o estado triste e deplorável em que se achavam as Escolas Menores pela falta de um sistema organizado de disciplinas necessárias à instrução pública, e a qualidade da instrução oferecida pelas mesmas, em que pouco se atendeu às necessidades locais.

Apontava-se a urgência de medidas disciplinadoras da atuação docente, a implantação de uma norma fixa e princípios claros para a nomeação e escolha dos professores, além de ressaltar a necessidade de permanente inspeção das atividades realizadas pelos professores, para que os professores cumpram suas obrigações com proficiência e zelo. Mas um obstáculo desanimador se interpunha: o desinteresse pela educação. Colonos e autoridades consideravam dispensável educar a população. Avaliavam politicamente perigosa a instrução dos súditos. Essa mentalidade obtusa que acabaria contaminado a sociedade em relação ao papel que a educação deve desempenhar para a formação de seus membros, ganhou contornos específicos de exclusão étnica quando se institui o Império brasileiro.

A educação passou a ser vista como interessante para conferir um lustro especial às elites da nobreza de títulos que acomodou os novos donos do poder e pincelou com ares de civilização as aspirações da pequena burguesia. As quatro décadas iniciais do século XIX demonstram claramente através de conflitos políticos cada vez mais frequentes e violentos que a luta pela cidadania plena nesta região seria sempre muito difícil para as classes oprimidas.

A explosão cabana representa o ápice, mas não o fim dessa aspiração de conquista de um espaço legítimo do exercício de direitos que teoricamente são assegurados a todos, mas nem sempre estão disponibilizados em quantidade e qualidade aos menos favorecidos economicamente.

A penúria de recursos financeiros sempre foi o principal obstáculo. A carência e a urgência desses recursos para atender às necessidades de uma educação extensiva a todos, desafio proposto pela conquista colonial e não resolvido, é agora renovado pelo estabelecimento de uma nacionalidade sobre este amplo espaço. Se os dominadores coloniais demarcaram o vasto território, cabia ao império brasileiro consolidá-lo e promover sua integração definitiva através da garantia dos direitos civis definidos em lei para todos os brasileiros.

Novamente a educação foi o instrumento escolhido e os professores os encarregados dessa tarefa de promover e consolidar a ideia de nação e assim, ideologicamente, obter a formação de cidadãos pacíficos e produtivos para a sociedade. As autoridades constituídas do período adaptaram sem muito empenho, as normas previstas no início do século XIX e escolas foram criadas em vilas e cidades de maior expressão, mas só poderíamos falar em melhorias do ensino na capital da Província. E as condições de exercício do ofício de professor permaneceram precários e mal remunerados.

\section{REFERÊNCIAS}

[1] Azevedo, João Lúcio d’. Os Jesuítas no Grão-Pará: suas missões e a colonização. Belém: Secult, \{1901\}1999.

[2] Almeida, Rita Heloisa de. O Diretório dos Índios. Um projeto de civilização no Brasil do século XVIII. Brasília: Editora UnB, 1997.

[3] Bastos, Maria Helena Camara; Faria Filho, Luciano Mendes de. (Orgs.). A escola elementar no século XIX. O método monitorial/mútuo. Passo Fundo/RS: EDIUPF, 1999.

[4] __ A formação de professores para o ensino mútuo no Brasil: O "Curso normal para professores de primeiras letras do Barão de Gérando (1839)". http://www.seer.ufrgs.br/asphe/article/viewFile/30722/pdf Consultado em 05/07/2015 
[5] Carvalho, José Murilo de. I A Construção da Ordem. II Teatro de Sombras. Rio de Janeiro: UFRJ/Relume Dumará, 1996.

[6] Castoriadis, Cornelius. A Instituição Imaginária da Sociedade. Tradução de Guy Reynaud. Rio de Janeiro: Paz e Terra, 1982.

[7] _ _ O Mundo Fragmentado. As encruzilhadas do Labirinto/3. Tradução: Rosa Maria Boaventura. Rio de Janeiro: Paz e Terra, 1992.

[8] Coelho, Geraldo Mártires. Anarquistas, Demagogos e Dissidentes. A Imprensa Liberal no Pará de 1822. Belém: CEJUP, 1993.

[9] Gondra, José Gonçalves; Schueler, Alessandra. Educação, poder e sociedade no império brasileiro. São Paulo: Cortez, 2008.

[10] Pará. Lei № 97, de 28 de junho de 1841. In.: Collecção das Leis da Província do Gram-Pará. Lei № 97, de 28 de junho de 1841. Tomo IV - parte 1ạ. Pará: Typ. Commercial de Antônio Joze Rabello Guimarães, 1855, p. 51-59.

[11] Raiol, Domingos Antônio. Motins Políticos. Vs. 1; 2; 3. Belém: EDUFPA,1970.

[12] Reis, Arthur Cesar Ferreira. Síntese de História do Pará. São Paulo: Gráfica da Revista dos Tribunais; Amada, 1972.

A Política de Portugal no Valle Amazônico. Belém: CEJUP; SECULT,1993.

[15] Vechia, Ariclê. O Ensino Secundário no Século XIX: Instruindo as Elites. In: Stephanou, Maria; Bastos, Maria Helena Camara. Histórias e Memórias da Educação no Brasil, V.II: Século XIX. Petrópolis, RJ: Vozes, 2006. 


\section{Capítulo 20}

\section{O planejamento estratégico no currículo do bacharelado em administração}

\section{Julio Cezar Arias \\ Mércia Freire Rocha Cordeiro Machado}

Resumo: 0 objetivo deste estudo é relacionar as Instituições de Ensino Superior (IES) que ofertam o curso de Bacharel em Administração no município de Curitiba e verificar a existência do componente curricular planejamento estratégico e sua relevância no currículo acadêmico. Para tanto, realizou-se, uma pesquisa qualitativa do tipo exploratória. Como instrumento de coletas de dados utilizou-se a pesquisa bibliográfica e documental para constituir o campo de pesquisa desta investigação. Diante disso, verificou-se que: i) na cidade de Curitiba, quatro instituições classificadas como Universidades e oito consideradas Faculdades oferecem o Curso de Bacharel em Administração; ii) as IES pesquisadas apresentam em suas matrizes um componente curricular exclusivo de Planejamento Estratégico, dos quais, algumas com cargas horárias um pouco maiores e a oferta em dois semestres; e iii) existe similaridade conceitual nas ementas do componente Planejamento Estratégico disponibilizadas pelas seis IES. Apesar das contribuições da pesquisa, os resultados devem ser analisados com cautela, devido, principalmente, pelo fato da população investigada ser composta por uma amostra das IES que oferecem a Graduação em Administração na cidade de Curitiba, fato este que inviabiliza generalizações e pode representar vieses do estudo. Como sugestões para trabalhos futuros, propõem-se investigar se os resultados aqui evidenciados são comuns em cursos de Bacharelado em Administração de outras regiões do país, permitindo validar ou não os resultados apresentados.

Palavras-chave: Planejamento Estratégico; Currículo; Bacharel em Administração. 


\section{INTRODUÇÃO}

Ao longo desses últimos tempos, a humanidade tem enfrentado desafios cada vez maiores para se adaptar às mudanças estruturais, tecnológicas, organizacionais e mercadológicas, que ocorrem em ritmo acelerado nesta era globalizada. Hoje, segundo Mello (2015), não basta identificar uma necessidade e atendê-la mediante o fornecimento de um produto ou serviço, é preciso fazer um esforço constante de inovação e criatividade para manter a competitividade. 0 que antes seria um diferencial competitivo é, hoje, um elemento essencial de sobrevivência e precisa de constante renovação para continuar a agregar valor (MELLO, 2015).

0 processo de globalização e o avanço da ciência e do conhecimento provocaram mudanças na sociedade, exigindo profissionais com novas capacidades, das quais, um perfil mais humanizado, integrado e capaz de interagir em todos os níveis laborais.

Frente a esse novo contexto, cabe ao profissional de Administração, ter uma formação diversificada, com base não apenas nas especificidades da área e em uma educação formal, mas, também, na experiência individual, ou seja, no conhecimento e vivência. Exige que o profissional seja capaz de agir e reagir em tempo real, pressupondo uma visão global e a longo prazo combinada a atitudes de adaptação e flexibilidade.

É para Mello (2015), cada vez mais extensa, a lista de qualidades exigidas desse profissional, que vão muito além das especificidades da área, como a polivalência e multitarefas; responsabilidade e confiabilidade; flexibilidade e adaptação; criatividade e inovação; iniciativa e empreendedorismo; respeito à sustentabilidade ambiental, social e econômica; trabalho em equipe e conexão em rede; capacidade de entrega; ética; entre outras.

Concomitantes a isso, as constantes mudanças no cenário econômico trazem à tona a necessidade, pelas empresas, por profissionais capacitados e dispostos a antecipar ações de mercado para torná-las cada vez mais produtivas e competitivas. Esse ambiente de mudanças têm exigido bacharéis em Administração capazes de redefinir e estruturar problemas, encontrar soluções inovadoras, assumir posturas éticas, dentre outras competências.

Diante desse cenário, a administração de empresas tornou-se um desafio que transcende o ambiente empresarial e a formação do administrador, que, de acordo com Paiva, Esther e Melo (2004) deve envolver um conjunto de práticas capaz de trazer contribuições, inovações e consequências positivas para além da formação profissional, contemplando uma formação sistêmica para o social e para a ética.

Assim, a necessidade dessa ação multidimensional demanda do profissional, segundo Machado (2016), um movimento contínuo de construção e reestruturação, de análise, reflexão e intervenções críticas e criativas de seus saberes. 0 reconhecimento da existência de suas múltiplas realidades e a legitimidade de todas elas é algo que torna a formação desses profissionais, em sua essência, um processo complexo (MACHADO, 2016).

O ensino superior em Administração, de acordo com Bolzan e Antunes (2016) foi introduzido no Brasil por volta de 1808, com base no modelo utilizado em Portugal, porém, não formava administradores, e sim, buscava qualificar mão-de-obra para atuar no comércio da época colonial. Contudo, segundo os autores, apenas em meados de 1930, com o apoio norte-americano, surgiram as escolas públicas e privadas destinadas à formação de administradores e desde então, o curso superior em Administração tem resultado das necessidades de adaptação da sociedade, que busca se alinhar ao desenvolvimento empresarial no país (BOLZAN; ANTUNES, 2016).

Os cursos de Administração no Brasil têm uma história muito curta, no entanto alcançaram dimensões significativas. Atualmente, o curso de bacharelado em Administração é um dos mais ofertados do país, possuindo um total de 710.984 matrículas, quantitativo que representa $8,83 \%$ do universo de estudantes regularmente matriculados no ensino superior (INEP, 2018). Durante o período de 2009 a 2013 o bacharelado em Administração foi o curso mais procurado nas instituições brasileiras. Em 2014 o bacharel em Direito assume a posição de curso brasileiro com maior número de matrículas e desde então o bacharel em Administração é o segundo curso superior mais procurado em Instituições de Ensino Superior (IES) (INEP, 2018).

Todavia, esse crescimento da oferta e procura do curso, para Bolzon e Antunes (2016), tem transformado a graduação em Administração em uma espécie de "produção em massa de administradores", e consequentemente, a referida "linha de produção" (o currículo pleno do curso) pode resultar em uma série de "produtos com baixa qualificação" (bacharéis em administração). 
O exercício profissional da Administração, de acordo com Lopes (2006), ocorre num contexto novo de grande dinamismo econômico e de rápidas mudanças no ambiente dos negócios, de modo que se definem exigências mais amplas que a simples utilização de um arsenal de técnicas gerenciais, subdividido em áreas específicas da organização, aplicáveis em contextos decisórios pré-definidos.

De acordo com as Diretrizes Curriculares Nacionais, do Conselho Nacional de Educação (CNE), Resolução № 4/2005, o Curso de Graduação em Administração deve ensejar como perfil desejado do formando, capacitação e aptidão para compreender as questões científicas, técnicas, sociais e econômicas da produção e de seu gerenciamento, observados níveis graduais do processo de tomada de decisão, bem como para desenvolver gerenciamento qualitativo e adequado, revelando a assimilação de novas informações e apresentando flexibilidade intelectual e adaptabilidade contextualizada no trato de situações diversas, presentes ou emergentes, nos vários segmentos do campo de atuação do administrador (BRASIL, 2005).

Assim, o bacharel em Administração deverá ser um profissional com atitudes gerenciais, políticas e de liderança, com capacidade para atuar como estrategista, executivo, consultor e empreendedor, bem como atuar na área acadêmica. Deverá também ser dotado de habilidades e conhecimentos generalistas que o qualifiquem para atuar e influir de forma proativa no mercado e na sociedade com responsabilidade e comportamento ético.

Com todas essas aptidões que o profissional administrador necessita, é de suma importância que ele possua conhecimento de planejamento estratégico para se destacar no ambiente empresarial. Considerando a importância do planejamento estratégico dentro do estudo da Administração, esse componente curricular tem a responsabilidade de desenvolver no aluno a capacidade de pensar estrategicamente as diversas áreas das organizações.

Diante do exposto, o objetivo desta investigação é relacionar as Instituições de Ensino Superior (IES) que ofertam o curso de Bacharel em Administração no município de Curitiba e verificar a existência do componente curricular Planejamento Estratégico e sua relevância no currículo acadêmico.

\subsection{CURRÍCULO DOS CURSOS DE ADMINISTRAÇÃO}

Inicialmente, segundo o CFA (2019), a criação e a evolução dos cursos de Administração no Brasil, se deram no interior de Instituições Universitárias, que se transformaram em pólos de referência para a organização e funcionamento desse campo. Posteriormente, a evolução desses cursos ocorreu, não mais vinculada às Instituições Universitárias, mas às Faculdades Isoladas que proliferaram no bojo do processo de expansão privatizada na sociedade brasileira (CFA, 2019).

Diante do crescimento das grandes empresas, principalmente estrangeiras e estatais, emergiu a necessidade por profissionais com qualificação específica para executar diferentes funções nas organizações. Assim sendo, essas empresas, de acordo com o CFA (2019), passaram a: i) adotar a profissionalização de seus quadros de funcionários, tendo em vista o tamanho e complexidade de seus arcabouços administrativos; e ii) empregar os administradores que passaram pelo sistema escolar.

Essas mudanças econômicas impulsionaram a profissionalização do Administrador e sua regulamentação profissional ocorreu em 1965 por meio da Lei no 4.769 e no seu artigo 3o, estabelece que o exercício da profissão de Técnico em Administração é privativo dos Bacharéis em Administração Pública ou de Empresas, diplomados no Brasil, em cursos regulares de ensino superior, oficial, oficializado ou reconhecido, cujo currículo deverá ser fixado pelo Conselho Federal de Educação (CFE), nos termos da Lei no 4.024/1961, que regulamenta as Diretrizes e Bases da Educação (LDB) no Brasil (BRASIL, 1965).

No ano seguinte à essa regulamentação, por meio do Parecer no 307/66, o CFE estabeleceu o currículo mínimo do curso de Administração. As diretrizes do parecer, de acordo com o CFA (2019), se inspiraram na análise das condições reais da Administração no País e nos postulados que emanavam da lei e da doutrina fixada na experiência nacional e internacional. Nesse currículo foram agrupadas áreas de cultura geral (Matemática, Estatística, Contabilidade, Teoria Econômica, Economia Brasileira, Psicologia e Sociologia Aplicada à Administração, Direito Administrativo, Público e Privado, Ética Administrativa, Legislação Social e Tributária, Teoria Geral da Administração, Administração Financeira, Orçamentária, de Pessoal, de Material, de Produção e de Vendas) com vistas: i) no conhecimento sistemático dos fatos e das condições institucionais nas quais se abrigam o fenômeno administrativo; ii) nos componentes curriculares instrumentais de caráter conceituais e/ou operacionais; e iii) no componente curricular de qualificação profissional. 
Com a liberdade dada pelo currículo, de acordo com o CFA (2019) as escolas poderiam ministrar as matérias do currículo mínimo com diferentes dosagens de tempo e de acento quanto aos objetivos, assim como organizar cursos ou seminários de aplicação mais restrita ou especializada. Desde então a profissão do administrador vem sendo regulamentada por meio de leis, resoluções normativas e deliberações por meio dos órgãos competentes, das quais destacamos:

Com a Lei 7.321 em 1986, os Técnicos em Administração passam a ser denominados administradores;

Com as Resoluções Normativas específicas do Conselho Federal de Administração (CFA) foi regulamentado, entre 1978 e 1989, o registro de Tecnólogo em áreas da Administração;

Com a criação da Associação Nacional dos Cursos de Graduação em Administração (ANGRAD) em 1991, os cursos de graduação em Administração ganham representação junto ao Ministério de Educação (MEC) e ao Conselho Nacional de Educação (CNE), entre outros;

Com a Lei de Diretrizes e Bases (LDB) no 9.394 em 1996, é dada a permissão para que o tecnólogo dê continuidade aos seus estudos em outros cursos e programas de educação superior, como extensão, pósgraduação, mestrado e doutorado;

Com a constituição do Fórum Nacional de Ensino de Administração (FONEAD) em 2001, formalizou-se a discussão das políticas de ensino da área no Brasil e sua interrelação com o exercício profissional;

Com a Resolução CNE nº 3, em 2002, os cursos superiores de tecnologia passam a ser considerados de graduação, com características especiais e ficam subordinados ao Parecer CNE/CES 436/2001, no qual o tempo de formação é de dois a três anos e buscam conciliar a teoria com a prática profissional;

Com a Resolução CNE no 4, em 2005 ficou proibida a existência de ênfases e habilitações (em Finanças, Marketing, Produção, Recursos Humanos entre várias) no curso, ou seja, o aluno se forma com diploma de bacharel em Administração, independentemente da linha de formação específica que escolher;

Com a Deliberação no 260 em 2005, foi regulamentado o registro profissional em Conselhos Regionais de Administração, dos Bacharéis em Administração, egressos de Cursos de Bacharelado em Administração, ministrados na modalidade à distância;

Com as Resoluções Normativas n.o 373 e 374 em 2009, o Conselho Federal de Administração, reeditou as resoluções anteriores para efeito de concessão de registro profissional.

Com as Resoluções Normativas n.o 506, 507, 511 e 512 de 2017, o Conselho Federal de Administração regulamentou registros no Conselho Regional de Administração dos bacharéis em cursos conexos à Administração; dos bacharéis egressos de cursos conexos à Administração Pública; dos egressos de cursos de educação profissional técnica de nível médio conexos à Administração e dos egressos de programas de Mestrado e Doutorado conexos à Administração, respectivamente.

Tais acontecimentos repercutiram significativamente, uma vez que, em um intervalo de 54 anos, o ensino de Administração alcançou uma dimensão substancial na sociedade brasileira, considerando que desde então tem reconhecimento oficial da categoria profissional e da ciência da Administração.

\subsection{PLANEJAMENTO ESTRATÉGICO NO CURRÍCULO DA GRADUAÇÃO EM ADMINISTRAÇÃO}

Segundo os autores Montana e Charnov (2010), a administração é o ato de trabalhar com e por intermédio de outras pessoas para realizar os objetivos das organizações. Além disso, segundo Maximiano (2015) tem como principais atividades: i) o Planejamento, que define objetivos, atividades e recursos; ii) a Organização, que define e divide o trabalho e recursos para realizar os objetivos; iii) a Liderança que trabalha com pessoas para assegurar a realização dos objetivos; iv) a Execução, que realiza atividades e consome recursos para atingir os objetivos; e v) o Controle que assegura a realização dos objetivos e identifica a necessidade de modificá-los. Ou seja, para o desenvolvimento de suas atividades, o profissional desenvolve sua capacidade de liderança, de trabalhar em equipe, de tomar decisões estratégicas e busca atingir os objetivos propostos com eficácia, eficiência e efetividade.

As características distintivas da Administração como área de atuação profissional, para Lopes (2006), acabam por impor uma reflexão acerca dos paradigmas que suportam as estruturas, métodos e técnicas utilizados no processo de formação do administrador. Por tratar-se de um conjunto teórico em construção que, nesse processo, apropria-se pragmaticamente de subconjuntos de outras ciências, exatas e humanas e, sobretudo, pela necessidade de maior subordinação de seus princípios aos contextos de sua aplicação, 
particularmente, quanto às especificidades dos sistemas organizacionais, a Administração apresenta uma complexidade correspondente à própria dinâmica do ambiente (LOPES, 2006).

Nesta perspectiva, o ensino da Administração objetiva desenvolver no aluno a capacidade intelectual de analisar todos os ambientes de uma organização e proporcionar ao profissional da área a possibilidade de se adequar às mais variadas circunstâncias, compreender o ambiente de negócios, lidar com problemas, propor soluções, incentivar o relacionamento interpessoal, entre outras competências. E para dar conta disso, o currículo do curso de Administração, envolve diversos campos de conhecimentos e práticas derivadas da articulação entre as áreas de Economia, Sociologia, Antropologia, Psicologia, Ciências Políticas, entre outras.

A materialização disso tudo se dá por meio do Projeto Pedagógico do Curso (PPC) no qual estão previstos a concepção e os objetivos gerais do curso, suas peculiaridades, a matriz curricular, a carga horária das atividades didáticas e a multidisciplinaridade, ou seja, o intercâmbio e a cooperação entre os vários componentes curriculares que compõem a matriz curricular. Dessa forma, o processo de ensino e a aprendizagem, se desenvolve, de acordo com Machado (2016), por meio de um conjunto de parâmetros educativos capazes de promover em cada participante do processo a capacidade de reorganizar suas funções cognitivas, de desenvolver novos recursos de linguagem, de potencializar áreas cognitivas, possibilitando o desenvolvimento da capacidade de operacionalizar com várias fontes de informação e redimensionar formas de convívio social, afetivo e cultural.

Para tanto, o currículo do bacharel em administração deve seguir os eixos básicos de formação estabelecidos na Resolução no 4/2005 do Conselho Nacional de Educação (CNE), além dos conteúdos de formação profissional, estudos quantitativos e formação complementar, o egresso, conforme estabelece o Art. $4^{\circ}$ da resolução, deve possuir conhecimentos e habilidades que o diferencie dos demais, dos quais,

I - reconhecer e definir problemas, pensar estrategicamente, introduzir modificações no processo produtivo, atuar preventivamente, transferir e generalizar conhecimentos e exercer, em diferentes graus de complexidade, $\mathrm{o}$ processo da tomada de decisão;

II - desenvolver expressão e comunicação compatíveis com o exercício profissional, inclusive nos processos de negociação e nas comunicações interpessoais ou intergrupais;

III - desenvolver raciocínio lógico, crítico e analítico para operar com valores e formulações matemáticas presentes nas relações formais e causais entre fenômenos produtivos, administrativos e de controle, bem assim expressandose de modo crítico e criativo diante dos diferentes contextos organizacionais e sociais;

IV - ter iniciativa, criatividade, determinação, vontade política e administrativa, vontade de aprender, abertura às mudanças e consciência da qualidade e das implicações éticas do seu exercício profissional;

$\mathrm{V}$ - desenvolver capacidade de transferir conhecimentos da vida e da experiência cotidianas para o ambiente de trabalho e do seu campo de atuação profissional, em diferentes modelos organizacionais, revelando-se profissional adaptável;

VI - desenvolver capacidade para realizar consultoria em gestão e administração, pareceres e perícias administrativas, gerenciais, organizacionais, estratégicos e operacionais (BRASIL, 2005).

Pensando nisso, o componente curricular "Planejamento Estratégico" foi escolhido para este estudo por proporcionar o conhecimento adequado a esse perfil de profissional, tornando-o um estrategista, com visão sistêmica e holística da organização em que atua.

O objetivo de se estudar "Planejamento Estratégico" é fornecer ao futuro administrador condições de adequar os negócios da empresa às constantes mudanças do mercado consumidor, de modo que a empresa seja sempre competitiva e lucrativa.

Segundo Oliveira (2011, p.53) "estratégia é a ação ou caminho mais adequado a ser executado para alcançar, preferencialmente de maneira diferenciada, os objetivos e metas estabelecidos." Os autores Chiavenato e Sapiro (2010, p. 4) definem estratégia como sendo um curso de ação escolhido pela 
organização a partir da premissa de que uma futura e diferente posição poderá oferecer ganhos e vantagens em relação à situação presente.

Sendo assim, a estratégia deve ser um plano de ação que, alinhado ao objetivo global da organização, permita estabelecer os caminhos a serem trilhados no âmbito empresarial. Pereira (2010, p. 44) complementa a teoria definindo planejamento como o "processo formalizado para gerar resultados a partir de um sistema integrado de decisões".

Com uma definição um pouco mais detalhada, Oliveira (2011, p. 5) define planejamento como "o desenvolvimento de processos, técnicas e atitudes administrativas que proporcionam uma situação viável de avaliar as implicações futuras de decisões presentes em função dos objetivos empresariais que facilitarão a tomada de decisão no futuro, de modo rápido, coerente, eficiente e eficaz".

Pensando o planejamento como um ato antecipado e tendo como pressuposto a mudança constante no cenário econômico e a escassez de recursos, podemos inferir que o planejamento é um processo dinâmico que deve conter em sua base, informações variadas de economia e mercado, recursos humanos e recursos materiais disponíveis, que possibilitem ao profissional desenvolver uma ferramenta que auxilie a tomada de decisão.

Um planejamento bem realizado deve servir como fonte basilar de consulta às organizações, e possibilitar algumas vantagens, tais como:

- $\quad$ Fornecer informações de demandas específicas de mercados;

- Permitir o controle mais enxuto da produção;

- Organizar o processo logístico de forma mais efetiva;

- Possibilitar a resolução rápida de conflitos;

- Propiciar um grau elevado de acerto nas decisões.

De forma geral, existem três tipos principais de planejamento que podem ser divididos conforme representado na figura 1 :

Figura 1 - Pirâmide Organizacional

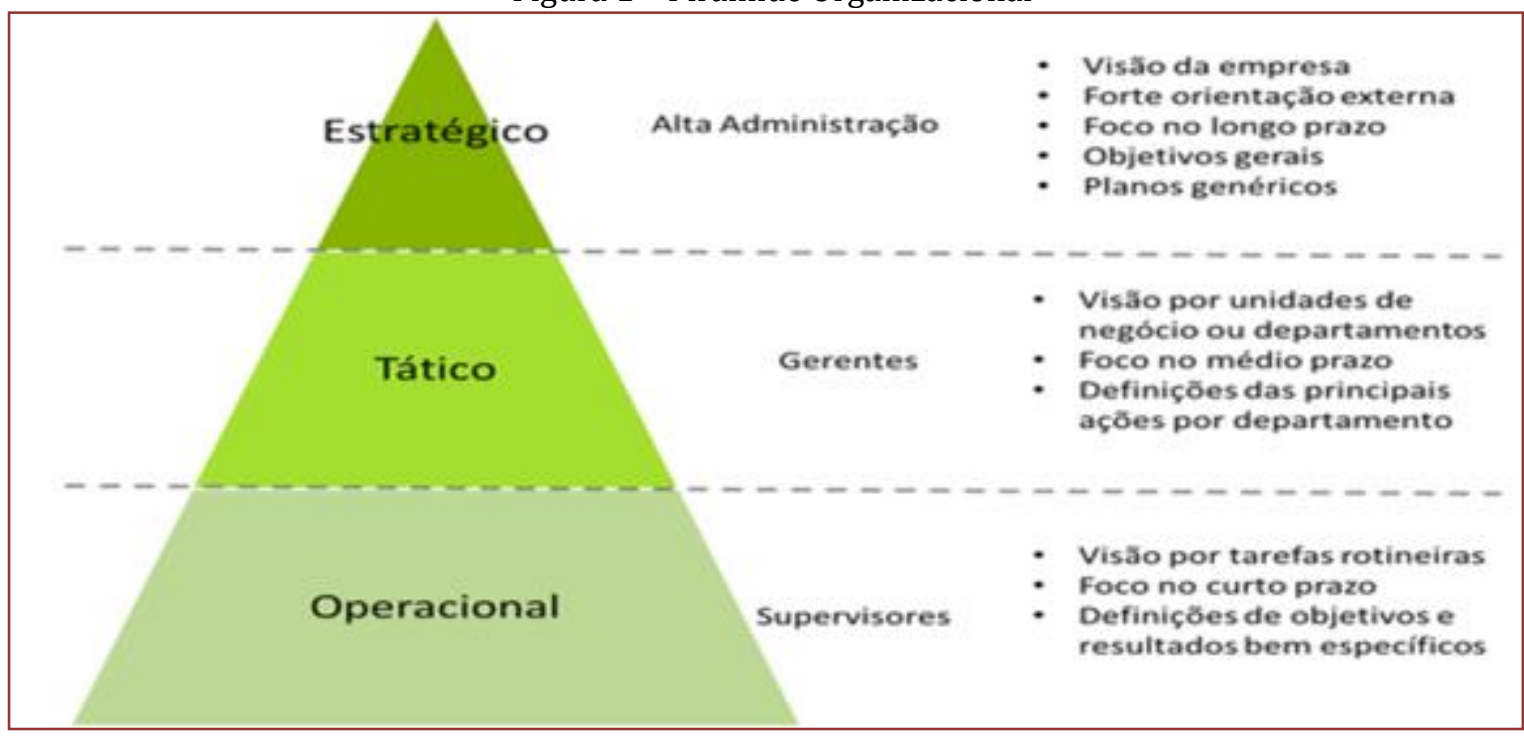

Fonte: http://www.quirius.com.br/o-guia-do-planejamento-tributario.

A figura acima ajuda a entender visualmente onde as ações do Planejamento Estratégico devem estar focadas.

O Planejamento Estratégico é o processo mais importante dentro de uma organização. Nele são definidas as estratégias de longo prazo, levando-se em conta o ambiente interno, o ambiente externo, as ameaças e 
as oportunidades. (Oliveira, 2011, p.19). Já o Planejamento Tático, segundo Oliveira (2011), é desenvolvido pelos níveis organizacionais intermediários, tendo como finalidade a utilização eficiente dos recursos, bem como as políticas orientativas. Por fim, o Planejamento Operacional é a formalização das metodologias de desenvolvimento e implementação de resultados específicos a serem alcançados pelas áreas funcionais da empresa. (Oliveira, 2011, p.19)

0 Planejamento Estratégico, segundo Kotler (1992, p.63), "é definido como processo gerencial de desenvolver e manter uma adequação razoável entre os objetivos e recursos da empresa e as mudanças e oportunidades de mercado". O objetivo de se estudar o planejamento estratégico é adequar os negócios da empresa ao mercado.

Planejamento Estratégico, para Fernandes e Berton (2005, p.11), é a formalização do pensamento estratégico em processos e procedimentos para que a empresa saiba exatamente os caminhos a serem seguidos. Assim, Pereira (2010, p. 47) define Planejamento Estratégico como:

[...] um processo que consiste na análise sistemática dos pontos fortes (competências) e fracos (incompetências ou possibilidades de melhorias) da organização, e das oportunidades e ameaças do ambiente externo, com o objetivo de formular (formar) estratégias e ações estratégicas com o intuito de aumentar a competitividade e seu grau de resolutividade.

Por mais simples que seja, um Planejamento Estratégico pode funcionar em qualquer organização, seja a partir de questões básicas ou através de ferramentas avançadas de diagnóstico. 0 importante é levar em conta todos os fatores internos e externos, tais como, os recursos financeiros existentes, o cenário econômico global e a situação de mercado em que a empresa atua.

Algumas questões fundamentais que podem ajudar na hora de realizar o Planejamento Estratégico de uma empresa: i) Onde estamos?; ii) Onde queremos chegar?; e iii) Como chegaremos lá?

Alguns autores conceituam o Planejamento Estratégico e ajudam a dar um entendimento um pouco mais aprofundado do assunto, conforme apresentado no quadro 1 abaixo:

Quadro 1 - Conceitos de Planejamento Estratégico

\begin{tabular}{|c|l|}
\multicolumn{2}{|c|}{ Quadro 1 - Conceitos de Planejamento Estratégico } \\
Autores & \multicolumn{1}{c|}{ Conceitos de Planejamento Estratégico } \\
\hline $\begin{array}{c}\text { Chiavenato e } \\
\text { Sapiro (2010) }\end{array}$ & $\begin{array}{l}\text { "Processo de formulação e execução de estratégias organizacionais para buscar a } \\
\text { inserção da organização e de sua missão no ambiente onde ele atua". }\end{array}$ \\
\hline $\begin{array}{c}\text { Fernandes e Berton } \\
(2005)\end{array}$ & $\begin{array}{l}\text { "O Planejamento Estratégico busca sistematizar o pensamento estratégico, formalizando } \\
\text { processos e procedimentos para que a empresa saiba exatamente os caminhos a seguir". }\end{array}$ \\
\hline Kotler (1992) & $\begin{array}{l}\text { "Planejamento estratégico é definido como o processo gerencial de desenvolver e } \\
\text { manter uma adequação razoável entre os objetivos e recursos da empresa e as } \\
\text { mudanças e oportunidades de mercado". }\end{array}$ \\
\hline Oliveira (2011) & $\begin{array}{l}\text { "Processo administrativo que proporciona sustentação mercadológica para se } \\
\text { estabelecer a melhor direção a ser seguida pela empresa". }\end{array}$ \\
\hline Pereira (2010) & $\begin{array}{l}\text { "Processo que consiste na análise sistemática dos pontos fortes e fracos da organização, } \\
\text { e das oportunidades e ameaças do ambiente externo, com o objetivo de formular } \\
\text { estratégias com o intuito de aumentar a competitividade". }\end{array}$ \\
\hline
\end{tabular}

Fonte: elaborado pelos pesquisadores com base nos autores acima, 2019.

A interatividade entre os componentes curriculares, principalmente aqueles que servirão de base para que o aluno adquira as competências e habilidades necessárias para o administrador desenvolver aquilo que se espera de um gestor, é fundamental.

Com base em Aktouf (2005), o administrador do futuro deverá ser capaz de integrar, com sua cultura geral, com sua experiência e sua intuição, diferentes componentes curriculares, diferentes conhecimentos, tanto no campo da administração em geral como no das ciências humanas. Isto exige dos professores que 
não sejam limitados a um campo de especialização, mas que tenham, ao contrário, uma abertura de espírito e uma grande cultura nos diferentes campos do saber.

\section{MATERIAIS E MÉTODOS}

Ao propor a análise dos currículos do curso de bacharelado em Administração, um levantamento inicial foi realizado com o intuito de verificar a existência do quesito Planejamento Estratégico em sua base, visto que o foco da pesquisa enfatiza esta subárea da Administração.

Por tratar-se de uma pesquisa qualitativa do tipo exploratória, segundo Severino (2007, p.123), em que busca apenas levantar informações acerca de determinado objeto, delimitando um campo de trabalho e mapeando as condições de manifestação desse objeto, o estudo partiu do pressuposto básico de que as matrizes curriculares da graduação em Administração pesquisadas continham o objeto "planejamento estratégico" arraigado em algum componente curricular ofertado, seja ele denominado Planejamento Estratégico ou Administração Estratégica.

No que diz respeito aos meios de investigação, ela atende à classificação de Vergara (2004), é bibliográfica, por fazer uso de livros, artigos, dentre outras publicações; e documental, pela análise de documentos específicos, devido à coleta de informação na Internet.

A pesquisa bibliográfica e documental: i) constituiu-se em etapas integradas, que só foram separadas para se compreender didaticamente a metodologia empregada, de modo a permitir a compreensão do processo e dos fenômenos estudados para responder aos objetivos a que se propôs esta pesquisa; e ii) tiveram como objetivos: i) constituir o objeto de pesquisa; ii) fundamentar o percurso teórico-metodológico da pesquisa; e iii) fundamentar a análise e discussão dos dados.

Os dados foram coletados com dois instrumentos: pesquisa nos sítios eletrônicos das IES, na área do curso de Administração, parte de matriz curricular, pesquisando pelo componente curricular Planejamento Estratégico e posterior solicitação da ementa do referido componente curricular, o que ocorreu pessoalmente e através de correio eletrônico, visto que o conteúdo mais específico como a ementa, não é disponibilizada nos sites.

A primeira etapa teve como objetivo visualizar o conteúdo obrigatório aos cursos de Administração, amparados na Resolução no 4/2005 do CNE (Conselho Nacional de Educação). 0 objetivo da análise documental foi identificar o campo de pesquisa, verificar os componentes curriculares ofertados e a frequência com que o Planejamento Estratégico é ofertado pelas instituições de ensino.

A segunda etapa consistiu em explorar as respectivas ementas e compará-las, em busca dos preceitos básicos oriundos do curso e do componente curricular em si. Dessa forma, a análise documental para esta pesquisa seguiu as orientações de Machado (2016), com as seguintes etapas:

a) Coleta dos documentos - Foi realizada nos sítios eletrônicos das diversas Instituições de Ensino Superior, que ofertam o curso de Administração na cidade de Curitiba - PR.

b) Organização dos documentos - Para estabelecer um parâmetro qualitativo, as matrizes curriculares foram analisadas sob uma visão focada no item Planejamento Estratégico, seguido da montagem de uma tabela com os respectivos componentes curriculares organizados por instituição de ensino.

c) Análise dos documentos - Para constituir o campo de pesquisa deste estudo, foram realizadas:

- Leitura dos livros e artigos citados na referência;

- Consultas relativas ao curso de Administração nos sítios eletrônicos das IES;

- Identificação do componente curricular Planejamento Estratégico nas referidas matrizes curriculares;

- Solicitação da ementa do componente curricular em questão;

- $\quad$ Análise das ementas disponibilizadas;

- Identificação dos pontos de convergência entre as ementas;

- Comparação, seguindo os critérios que a Diretriz Curricular orienta, acerca do conteúdo que deve ser ofertado nos componentes curriculares do curso de Administração. 


\section{ANÁLISE E DISCUSSÃO DOS DADOS}

Com base na análise documental, constatou-se que a cidade de Curitiba - PR apresenta uma grande quantidade de Instituições de Ensino Superior (IES) que ofertam o curso de bacharel em Administração. Assim, para esta pesquisa foram escolhidas as principais IES (QUADRO 1), que, de alguma forma, foram localizadas com mais facilidade nos mecanismos de busca da Internet, das quais destacamos: i) quatro instituições classificadas como Universidades; ii) oito instituições consideradas como Faculdades, conforme classificação amparadas pelo Decreto no 5.773/2006 do Ministério da Educação e Cultura (MEC).

Quadro 1 - IES que ofertam a graduação em Administração no município de Cu
\begin{tabular}{|l|c|}
\hline \multicolumn{1}{|c|}{ IES } & Carga horária \\
\hline FACULDADE BAGOZZI - Faculdade Padre João Bagozzi & $3.344 \mathrm{~h}$ \\
\hline FAE - Centro Universitário & $2.880 \mathrm{~h}$ \\
\hline UNIOPET - Centro Universitário & $3.000 \mathrm{~h}$ \\
\hline PUCPR - Pontifícia Universidade Católica do Paraná & $3.930 \mathrm{~h}$ \\
\hline FARESC - Faculdades Integradas Santa Cruz de Curitiba & $3.096 \mathrm{~h}$ \\
\hline SPEI - Sociedade Paranaense de Ensino e Informática & $3.040 \mathrm{~h}$ \\
\hline UFPR - Universidade Federal do Paraná & $3.060 \mathrm{~h}$ \\
\hline UNIBRASIL - Centro Universitário & $3.600 \mathrm{~h}$ \\
\hline UNICURITIBA - Centro Universitário Curitiba & $3.654 \mathrm{~h}$ \\
\hline UNINTER - Centro Universitário Internacional & $3.344 \mathrm{~h}$ \\
\hline UP - Universidade Positivo & $3.680 \mathrm{~h}$ \\
\hline UTP - Universidade Tuiuti do Paraná & $3.040 \mathrm{~h}$ \\
\hline
\end{tabular}

Fonte: elaborado pelos pesquisadores com base nos dados da pesquisa, 2017.

De acordo com a Resolução no 2, de 18 de junho de 2007 estabelece para o curso de graduação em Administração: i) a carga horária mínima de 3.000 horas; e ii) o limite mínimo para integralização do curso de 4 (quatro) anos (BRASIL, 2007).

Diante do exposto, verifica-se que apenas a FAE oferece o curso com carga horária abaixo do disposto pela resolução. As demais IES oferecem seus cursos com a carga horária total de 3.000 horas a 3.930 horas, cumprindo portanto o estabelecido pela resolução.

0 art. 5o da Resolução CNE/CES n 4/2005 estabelece que os cursos de graduação em Administração deverão contemplar, em seus projetos pedagógicos e em sua organização curricular, conteúdos que revelem inter-relações com a realidade nacional e internacional, segundo uma perspectiva histórica e contextualizada de sua aplicabilidade no âmbito das organizações e do meio através da utilização de tecnologias inovadoras e que atendam aos seguintes campos interligados de formação (BRASIL, 2005). E estabelece que os conteúdos de formação profissional devem ser relacionados com as áreas específicas, envolvendo teorias da administração e das organizações e a administração de recursos humanos, mercado e marketing, materiais, produção e logística, financeira e orçamentária, sistemas de informações, planejamento estratégico e serviços (BRASIL, 2005).

Baseando-se nesse eixo de formação, verificou-se que as IES pesquisadas mantêm em suas matrizes curriculares o componente curricular denominado Planejamento Estratégico (QUADRO 2), algumas com mais ênfase e cargas horárias um pouco maiores e, em outras, a oferta se dá em dois semestres letivos. 
Analisando o quadro 2, verifica-se que a carga horária disponibilizada individualmente entre os componentes curriculares é equivalente, na maioria das vezes, e comparando os componentes curriculares, percebe-se que suas nomenclaturas se alternam entre Planejamento Estratégico e Administração Estratégica, porém, o conteúdo distribuído ao longo do período letivo se equipara, na medida em que contempla as principais competências a serem adquiridas pelo aluno, constantes nas Diretrizes Curriculares do Conselho Nacional de Educação.

Quadro 2 - Componentes curriculares ofertados nas diferentes IES e suas respectivas cargas horárias

\begin{tabular}{|c|c|c|}
\hline IES & $\begin{array}{l}\text { Nome e Período em que o componente } \\
\text { curricular é ofertado }\end{array}$ & Carga horária \\
\hline $\begin{array}{l}\text { FACULDADE BAGOZZI - Faculdade Padre João } \\
\text { Bagozzi }\end{array}$ & Planejamento Estratégico ( $7^{\circ}$ ) & $80 \mathrm{~h}$ \\
\hline FAE - Centro Universitário & Administração Estratégica (6º $)$ & $72 \mathrm{~h}$ \\
\hline UNIOPET - Centro Universitário & $\begin{array}{l}\text { Planejamento Estratégico (5ํㅜㄱ } \\
\text { Administração Estratégica ( } 8^{\circ} \text { ) }\end{array}$ & $\begin{array}{l}72 \mathrm{~h} \\
72 \mathrm{~h}\end{array}$ \\
\hline PUCPR - Pontifícia Universidade Católica do Paraná & $\begin{array}{c}\text { Administração Estratégica (6ำ) } \\
\text { Planejamento e Desenvolvimento } \\
\text { Estratégico }\left(7^{\circ}\right)\end{array}$ & $\begin{array}{l}72 \mathrm{~h} \\
80 \mathrm{~h}\end{array}$ \\
\hline $\begin{array}{l}\text { FARESC - Faculdades Integradas Santa Cruz de } \\
\text { Curitiba }\end{array}$ & $\begin{array}{l}\text { Planejamento Estratégico I ( } 5^{\circ} \text { ) } \\
\text { Planejamento Estratégico II ( } 6^{\circ} \text { ) }\end{array}$ & $\begin{array}{l}72 \mathrm{~h} \\
72 \mathrm{~h}\end{array}$ \\
\hline SPEI - Sociedade Paranaense de Ensino e Informática & Planejamento Estratégico ( $8^{\circ}$ ) & $80 \mathrm{~h}$ \\
\hline UFPR - Universidade Federal do Paraná & Administração Estratégica (6º) & $60 \mathrm{~h}$ \\
\hline UNIBRASIL - Centro Universitário & Administração Estratégica (6º) & $80 \mathrm{~h}$ \\
\hline UNICURITIBA - Centro Universitário Curitiba & Planejamento Estratégico (7ํㅜㄱ) & $72 \mathrm{~h}$ \\
\hline UNINTER - Centro Universitário Internacional & Administração Estratégica (6º) & $56 \mathrm{~h}$ \\
\hline UP - Universidade Positivo & Planejamento Estratégico ( $4^{\circ}$ ano) & $80 \mathrm{~h}$ \\
\hline UTP - Universidade Tuiuti do Paraná & 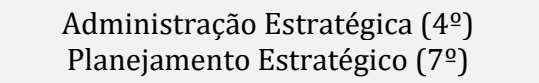 & $\begin{array}{l}72 \mathrm{~h} \\
72 \mathrm{~h}\end{array}$ \\
\hline
\end{tabular}

Fonte: elaborado pelos pesquisadores com base nos dados da pesquisa, 2017.

A maioria das IES pesquisadas não disponibilizam as ementas dos componentes curriculares em suas páginas, e isso dificultou o acesso a essas informações. Diante disso, foram realizados contatos de forma presencial por meio de visita à instituição, e outras, disponibilizadas através de correio eletrônico. Ao final do processo de pesquisa, teve-se acesso a apenas seis ementas do componente Planejamento Estratégico dos cursos pesquisados. Após a análise das ementas disponibilizadas por algumas IES, percebeu-se que elas possuem muita similaridade conceitual, conforme apresentado no quadro 3. 
Quadro 3 - Conteúdo resumido das ementas dos componentes curriculares Administração Estratégica e Planejamento Estratégico.

\begin{tabular}{|c|l|}
\hline $\begin{array}{c}\text { FACULDADE BAGOZZI - Faculdade Padre } \\
\text { João Bagozzi }\end{array}$ & $\begin{array}{l}\text { Proporcionar visão abrangente da organização [...]. Aplicar os } \\
\text { conceitos teóricos e ferramentas do planejamento estratégico. }\end{array}$ \\
\hline $\begin{array}{c}\text { PUCPR - Pontifícia Universidade Católica } \\
\text { do Paraná }\end{array}$ & $\begin{array}{l}\text { Administrar estrategicamente com referência global. Conceitos } \\
\text { principais. Organização e ambiente. Formulação de estratégias. } \\
\text { Implementação de estratégias. Controle estratégico. }\end{array}$ \\
\hline UFPR - Universidade Federal do Paraná & $\begin{array}{l}\text { Desenvolver a compreensão sobre os conceitos de Planejamento e } \\
\text { Administração Estratégica. Análise estratégica dos ambientes interno } \\
\text { e externo. Formação e formulação da estratégia. Acompanhamento do } \\
\text { processo estratégico. }\end{array}$ \\
\hline UNIBRASIL - Centro Universitário & $\begin{array}{l}\text { Reconhecer e definir problemas, equacionar soluções, pensar } \\
\text { estrategicamente, introduzir modificações no processo produtivo, } \\
\text { atuar preventivamente, transferir e generalizar conhecimentos e } \\
\text { desenvolver raciocínio lógico, crítico e analítico. }\end{array}$ \\
\hline UNICURITIBA - Centro Universitário & $\begin{array}{l}\text { C componente curricular enfoca a importância de se ter uma visão } \\
\text { abrangente que vai desde a fixação de prioridades pela direção da } \\
\text { organização quanto ao atendimento das necessidades dos clientes. A } \\
\text { sua abordagem é a de procurar aplicar os conceitos teóricos } \\
\text { apresentados nesta e em outros componentes curriculares a uma } \\
\text { situação real empresarial. }\end{array}$ \\
\hline UTP - Universidade Tuiuti do Paraná & $\begin{array}{l}\text { Capacitar o aluno a elaborar um plano estratégico. Enfatizar a } \\
\text { importância de se ter uma visão abrangente da organização. }\end{array}$ \\
\hline
\end{tabular}

Fonte: elaborado pelos pesquisadores com base nos dados da pesquisa, 2017.

O conteúdo da ementa deve ser uma descrição do conteúdo conceitual e procedimental de um componente curricular. Além disso, o componente curricular deve propiciar não só o conteúdo teórico formal, mas também as experiências, a metodologia constante no processo de ensino-aprendizagem, fazendo com que o aluno resgate os conhecimentos prévios e construa conceitos ressaltando a individualidade e contexto social de cada um. Pelo que foi analisado, as ementas possuem objetivos claros, pré-definidos e em convergência com as diretrizes educacionais e também com as demandas de mercado, visto que o planejamento é peça chave na administração como um todo e na perenidade das organizações.

\section{CONSIDERAÇÕES FINAIS}

Esta investigação objetivou relacionar as Instituições de Ensino Superior (IES) que ofertam o curso de Bacharel em Administração no município de Curitiba e verificar a existência do componente curricular Planejamento Estratégico e sua relevância no currículo acadêmico.

Os resultados apontam que a análise das matrizes curriculares da graduação em Administração das IES pesquisadas permitiu verificar que os componentes curriculares que tratam de gestão, estratégia ou planejamento, sendo denominadas Planejamento Estratégico ou Administração Estratégica possuem o mesmo papel no processo de ensino-aprendizagem. Diante disso, demonstrou-se que o componente curricular Planejamento Estratégico tem grande relevância na formação dos alunos, por proporcionar a convergência entre os conceitos adquiridos ao longo do curso, nas práticas acadêmicas, estudos de caso e suas experiências profissionais.

A ocorrência do componente curricular Planejamento Estratégico se deu, na maioria das vezes, a partir do 6ํㅜ período, devido à sua complexidade e relevância. Nela verificou-se a aplicação dos principais conceitos e ferramentas desenvolvidas ao longo do curso de Administração. A complexidade na verificação do cumprimento das orientações nacionais relativos a carga horária mínima, procedimentos relativos à integralização e duração dos cursos ficou comprometida devido a dificuldade na obtenção das ementas e a 
necessidade constante de buscas no desenvolvimento da pesquisa e a falta de padronização dos sítios eletrônicos das IES pesquisadas.

A carga horária disponibilizada em suas matrizes curriculares pelas IES pesquisadas demonstra a diferença de enfoque que elas possuem no ensino do Planejamento Estratégico e da Administração Estratégica, pois em algumas instituições é oferecida em um semestre (72h) e em outras, em dois semestres (144h). A presença constante do componente Planejamento Estratégico nos currículos das instituições pesquisadas, seja em um ou dois semestres, mostra a importância e relevância com que esse assunto é tratado no âmbito acadêmico e empresarial.

Apesar das contribuições da pesquisa, os resultados devem ser analisados com cautela, devido, principalmente, pelo fato da população investigada ser composta por uma amostra das IES que oferecem a Graduação em Administração na cidade de Curitiba, fato este que inviabiliza generalizações e pode representar vieses do estudo. Como sugestões para trabalhos futuros, propõem-se investigar se os resultados aqui evidenciados são comuns em cursos de Bacharelado em Administração de outras regiões do país, permitindo validar ou não os resultados apresentados.

\section{REFERÊNCIAS}

[1] Aktouf, Omar. Ensino de Administração: por uma pedagogia para a mudança. Revista Organizações e Sociedades. Salvador. Volume 12. N. 35, p.152-159, 2005.

[2] Bolzan, L. M.; Antunes, E. D. D. O que clamam as vozes dos pesquisadores e sobre o que elas calam ao abordarem o ensino em administração no Brasil? Revista ADM - MADE, ano 15, v. 19, n. 3, p. 77-93, 2015.

[3] Brasil. Ministério da Educação. Lei no 4.769, de 9 de setembro de 1965. Disponível em http://www.planalto.gov.br/ccivil_03/leis/L4769.htm. Acesso em 19/06/2019.

[4] Brasil. Ministério da Educação. Resolução no 4, de 13 de julho de 2005. Dispõe sobre as Diretrizes Curriculares Nacionais do Curso de Graduação em Administração. Brasília, 2005. Disponível em: <http://portal.mec.gov.br/cne/arquivos/pdf/rces004_05.pdf>. Acesso em 06/11/2018.

[5] Brasil. Ministério da Educação. Resolução no 2, de 18 de junho de 2007. Dispõe sobre carga horária mínima e procedimentos relativos à integralização e duração dos cursos de graduação, bacharelados, na modalidade presencial. Brasília, 2007. Disponível em http://portal.mec.gov.br/cne/arquivos/pdf/2007/rces002_07.pdf. Acesso em Acesso em 19/06/2019.

[6] Chiavenato, Idalberto; SAPIRO, Arão. Planejamento Estratégico: Fundamentos e aplicações. 2ª ed, Rio de Janeiro: Elsevier, 2010.

[7] Conselho Federal de Administração. História da Profissão. 2019. Disponível em: https://cfa.org.br/administracao-administracao/administracao-historia-da-profissao/. Acesso em: 21/06/2019.

[8] Instituto Nacional de Estudos e Pesquisas Educacionais Anísio Teixeira. Sinopse Estatística da Educação Superior 2017. Brasília: Inep, 2018. Disponível em http://portal.inep.gov.br/web/guest/sinopses-estatisticas-daeducacao-superior. Acesso em 20/06/2019.

[9] Fernandes, B. H. R.; Berton, L. H. Administração estratégica: da competência empreendedora à avaliação de desempenho. 1. ed. São Paulo: Saraiva, 2005.

[10] Kotler, Philip. Administração de marketing: análise, planejamento, implementação e controle. 2. ed. São Paulo: Editora Atlas, 1992.

[11] Lopes, Paulo da Costa. A formação do administrador no ensino de graduação: uma reflexão. Semina: Ciências Sociais e Humanas, Londrina, v. 27, n.2, p. 187-201, jul./dez. 2006.

[12] Machado, Mércia Freire Rocha Cordeiro. As contribuições e implicações da mediação pedagógica na formação continuada de professores da Educação Profissional e Tecnológica à Distância. 2016. Tese (Doutorado em Educação) Pontifícia Universidade Católica do Paraná, Curitiba, 2016.

[13] Maximiano, Antônio Cesar Amaru. Fundamentos da Administração: introdução à teoria geral e aos processos da administração. 3ํe ed, Rio de Janeiro: LTC, 2015.

[14] Mello, Sebastião Luiz de. Tendências e desafios dos profissionais de administração. Conselho Federal de Administração (Brasil). 50 anos que fizeram história: jubileu de ouro: Sistema CFA/CRAs / Conselho Federal de Administração. - Brasília, DF, 2015. 2a Edição.

[15] Montana, P. J.; Charnov, B. H. Administração: série essencial. 3. Ed, São Paulo: Saraiva, 2010.

[16] Oliveira, Djalma de Pinho Rebouças de. Planejamento Estratégico: Conceitos, Metodologia, Práticas. 29. ed, São Paulo: Atlas, 2011. 
[17] Paiva, K. C. M.; Esther, A. B.; MELO, M. C. O. L. Formação de competências e interdisciplinaridade no ensino de administração: uma visão dos alunos. Revista Gestão e Planejamento, v. 5, n. 2, p. 63-77, 2004.

[18] Pereira, Maurício Fernandes. Planejamento Estratégico: teorias, modelos e processos. São Paulo: Atlas, 2010.

[19] Severino, A. J. Metodologia do Trabalho Científico. 23aㅡ ed, São Paulo: Cortez, 2007.

[20] Vergara, Sylvia Constant. Projetos e Relatórios de Pesquisa em Administração. 5ạ. ed, São Paulo: Atlas, 2004. 


\section{Capítulo 21}

Dermeval Saviani em "História das ideias pedagógicas no Brasil" e a utilização do método abdutivo: Uma contribuição para a socialização do conhecimento

\section{Isabela Araujo Lima}

Gledson Lima Alves

Resumo: 0 presente estudo buscou compreender o ponto do diálogo em comum da obra de Demerval Saviani, intitulada "História das ideias pedagógicas do Brasil" com a obra de Umberto Eco e Sebeok, T. A., intitulada "O signo de três". 0 objetivo geral foi identificar a manifestação dos pontos afins, isto é, os de convergência entre as referidas obras e os seus aspectos de influenciação nas escolhas teórico-metodológicas adotadas por Saviani. Sabemos que o autor utiliza o método dialético-histórico, no entanto, tecemos uma relação desse método com o método abdutivo, destacando comentários sobre o rigor metodológico aplicado à sua pesquisa científica na área da História da Educação e o desenvolvimento do raciocínio crítico, contribuindo para a socialização do conhecimento. A relevância social deste trabalho está no fato de asseverar uma maior consistência e coerência na ação educativa desenvolvida por Saviani, demarcando a sua metodologia, construída a partir de diversas inspirações teóricas para a compreensão da evolução do pensamento pedagógico brasileiro, contribuindo sobremaneira para o desenvolvimento do trabalho dos professores, dirigentes e sistemas de ensino neste país. Para a realização desse trabalho, foi utilizada a pesquisa bibliográfica baseada nos autores e obras acima mencionados. Concluiu-se que o raciocínio abdutivo desenvolvido por Peirce, e relatado por Eco, infere-se na lógica daquilo que poderia ser, indo-se ao encontro de novas possibilidades, o que podemos identificar em Saviani quando do seu desafio em reunir diversas e incontáveis fontes, a fim de superar as dificuldades metodológicas tradicionais. Dessa forma, a socialização do conhecimento proposta por Saviani concretiza-se quando ele dispõe à pesquisa acadêmica a possibilidade de extração de suas críticas através do método abdutivo, propondo deixar os resultados de seus estudos aos professores e educandos das escolas brasileiras em geral, enfatizando também a necessidade do alcance ao ensino público, afim de para melhorá-lo.

Palavras-chave: História das ideias pedagógicas. Educação brasileira. Método abdutivo. Socialização do conhecimento. 


\section{INTRODUÇÃO}

A educação brasileira contemporânea teve um percurso temporal de desenvolvimento pedagógico mediante sua construção histórica a partir do descobrimento das "terras brasilis" pelos portugueses. Ao falar em história da pedagogia neste país, não há como deixar de se remeter a Demerval Saviani (2013), filósofo, pedagogo brasileiro, autor de "História das ideias pedagógicas no Brasil", obra que resgata a origem da educação brasileira até os dias atuais.

Nesse sentido, a obra de Saviani (2013) é amparada mediante escolhas teórico-metodológicas influenciadas pela sua formação crítica acadêmica, de acordo com os aspectos intratextuais, extratextuais e intertextuais. Dessa maneira, pode-se inferir que há algum ponto de interseção do pensamento exposto na obra "O signo de três" (1983) com a obra "História das ideias pedagógicas no Brasil" de Saviani (2013)? Se sim, qual seria a contribuição para a educação brasileira? Eis então a temática a ser esclarecida.

A história das ideias pedagógicas no Brasil reflete sobremaneira a complexidade do contexto em que estamos inseridos e apresenta-se como uma importante ferramenta de socialização do conhecimento, já que compreender o passado nos ajuda a desenvolver o pensamento crítico sobre o que ocorre no presente. Difundir esses conhecimentos e dispô-los ao alcance do professor e da sala de aula contribui para um honroso intento.

Quanto a isso, Saviani destaca-se por sua intensa dedicação à pesquisa científica, ao avanço e à socialização do ensino público no nosso país. 0 autor contribui, além disso, como exemplo para todos os pesquisadores de rigorosa e rica aplicação da teoria e metodologias científicas, fazendo-se valer de uma vasta exploração das mais diversas fontes e do método dialético-histórico para a formulação de suas hipóteses críticas. Relacionamos, pois, durante a discussão do presente estudo, esse método ao método abdutivo pensamento exposto por Eco e Sebeok (1983) em "O signo de três".

A relevância em perceber a construção do pensamento desenvolvido por Saviani (2013) ocorreu diante das dificuldades e esforços encontrados nos paradigmas tradicionais da historiografia brasileira, como também, no investimento intelectual dispensado nesta atividade visando encontrar o momento do "diálogo" das obras e dos autores envolvidos, a partir de uma proposta acadêmica.

\section{METODOLOGIA}

Assim, a nossa metodologia baseia-se em revisão bibliográfica das obras e autores citados, com o objetivo de tecer uma discussão, destacando os seus pontos de convergência, apresentando como contribuição acadêmica o enfoque dos meritosos subsídios sociais que Saviani proporciona à pesquisa científica e à educação socializada.

A estrutura da exposição do presente exame, está dividida em partes tais como a Introdução, em que expomos a justificativa, objetivos, relevância da temática, a síntese da metodologia utilizada e os limites do alcance argumentativo. Em seguida, o corpo do trabalho demonstra o cerne principal da discussão, chegando às considerações finais.

\section{FUNDAMENTOS TEÓRICO-METODOLÓGICOS, CONSTRUÇÃO DE HIPÓTESES ABDUTIVAS E A SOCIALIZAÇÃO DO SABER NA “HISTÓRIA DAS IDEIAS PEDAGÓGICAS NO BRASIL" (DISCUSSÃO E RESULTADOS)}

"Observo que este livro é um primeiro esforço no sentido de colocar ao alcance dos professores um recurso que lhes permita abordar a educação brasileira em seu conjunto, desde as origens até os dias atuais". (SAVIANI, 2013).

De acordo com a sua biografia profissional e acadêmica, as publicações de Demerval Saviani (2013) estrategicamente foram direcionadas para o público alvo de suas ideias, os professores. A obra "História das ideias pedagógicas no Brasil", representa muito bem a sua afirmativa quando ao final da introdução estabelece a sua principal finalidade "(...)em contribuir para o desenvolvimento do trabalho dos professores nas salas de aula, assim como dos dirigentes das escolas e sistemas de ensino, (...)". 
Ao experienciarmos, em Saviani, a abordagem e a exposição das ideias pedagógicas e suas trajetórias numa visão de conjunto da história da educação brasileira, observamos que se trata de um trabalho científico cuidadosamente apoiado em fontes primárias e secundárias, visando equacionar as várias questões identificadas, dada a vultosa quantidade de informações reunidas. (SAVIANI, 2013, p. xx).

Foram levantadas e examinadas diversas fontes documentais, clássicas e historiográficas acerca do objeto referido, periodizando-o desde a chegada dos jesuítas ao Brasil até o início do século XXI. Foi feita, assim, uma ampla e complexa investigação, motivada por projeto de pesquisa histórico-educativa, que fora iniciada no ano de 1989, visando a retrospectiva histórica da escola pública no Brasil (1870-1996), dividindo-se em quatro períodos, compreendidos linearmente, com a contextualização histórica geral, em que os fatos marcantes, como, mudanças e acontecimentos específicos foram destacados, seguindo-se das ideias pedagógicas.

A obra foi fundamental para que se observe que a periodização coloca as ideias pedagógicas em contraposição às ideias sistematizadas, hegemônicas até os idos dos anos de 1980, e que segundo o autor "as simplificações teóricas que, muito mais que esterilizar o pensamento de um autor, contribuem para a esterilização do procedimento científico” (SAVIANI, 2013).

A investigação de Saviani, não obstante, demonstra concepções educacionais de cada período histórico. Enfatiza também a identificação e classificação da organização escolar, abordando esquematicamente algumas tendências do momento presente, numa tentativa de reflexão sobre os rumos da educação na contemporaneidade. (SAVIANI, 2013, p. 02).

Nas palavras do autor, em seu prefácio, temos que uma das suas intenções com os resultados dessa vasta e compensadora pesquisa seria socializar os seus frutos, embora haja ainda muito a investigar. (SAVIANI, 2013, p. xxvii).

A obra faz prevalecer recortes particulares na pesquisa histórico-educativa, a partir de fontes disponíveis, construindo sínteses explicativas de amplo alcance que podem integrar programas escolares, viabilizando sua socialização. É com esse intuito que Saviani afirma incidir seus estudos, a respeito da obra em tela, "mais sobre a síntese do que sobre a análise", não sobrepujando, porém, a importância dos estudos analíticos. (SAVIANI, 2013, p. xviii).

Permitir articular a compreensão de amplo alcance sobre resultados de investigações particulares referentes ao tautócrono da história da educação brasileira contribui para a estruturação de uma visão geral carente aos destinatários preferenciais visados pelo autor: os professores. Deste modo, a obra contribui para a formação docente a para a prática da difusão desses conhecimentos em sala de aula, evidenciando a amplitude social. (SAVIANI, 2013, p. xvi).

A socialização do conhecimento defendida por Saviani integra o caráter que promove um processo motivado pela sensibilização e interiorização de conteúdos valorativos para a construção do sujeito social, tarefa prioritária para a defesa de uma educação pública de qualidade e acessível para todos os brasileiros. (SAVIANI, 2013, p. 449).

Impõe, portanto, uma práxis que democratiza o ensino atingindo às mais variadas classes sociais com a difusão do conhecimento científico e seus resultados sem segregá-los ao alcance de poucos, transformando-se em importante instrumento educativo e recurso indispensável aos pesquisadores.

Além disso, ao esclarecer de imediato sua acepção pelos termos “ideias pedagógicas”, o autor reforça suas ideias socializadoras ao traduzi-las como expressão da concretude laboral do educador. Assim, relacionaas muito mais à prática educacional, encarnando as necessidades educacionais de nosso tempo.

Por ideias pedagógicas entendo as ideias educacionais, não em si mesmas, mas na forma como se encarnam no movimento real da educação, orientando e, mais do que isso, constituindo a própria substância da prática educativa. (SAVIANI, 2013, p. 6).

A perspectiva teórico-metodológica utilizada por Saviani nesta obra assume aportes em Marx e Gramsci e foi construída sob a égide criteriosa do método dialético-histórico e de cinco princípios como o "caráter concreto do conhecimento histórico-educacional" sob uma "perspectiva de longa duração", estabelecendo o "olhar analítico sintético" no trato das fontes, na "articulação do singular e do universal" com diretriz na "atualidade da pesquisa histórica", respectivamente. Ademais, a pesquisa demonstra, concomitantemente, afinco no levantamento e na crítica de inúmeras fontes de investigação, dentre elas uma vasta lista de referências bibliográficas. (SAVIANI, 2013, p. 3). 
O método dialético-histórico que Saviani desenvolve consiste em, diante daquilo que se apresenta como verdade (tese), realiza-se a contradição (antítese) pelo confronto com outras realidades e teorias, para daí se encaminhar à síntese criativa e transformadora, a novas teorias. A relação desse método com o método de abdutivo, proposta aqui, é a análise que colocamos em discussão.

A partir desse ponto, encontra-se o momento de coalisão com o raciocínio abdutivo compreendido por Pierce (Eco, 1983), uma vez que, Saviani (2013) desenvolve um conjunto de hipóteses como resultado da pluralidade teórico-metodológicas para sustentar a sua concepção de conhecimento histórico-educacional, isto posto nas cinco diretrizes, das quais destacamos a exigência de explicitar a complexidade das relações e determinações da educação brasileira, o cuidado para com o trato das fontes, buscando não desconfigurar o fenômeno investigado, permitindo que o exame das fontes estivesse alinhado entre os processos local, nacional e internacional. Por fim, o princípio da atualidade da pesquisa histórica, que se deve firmar num estado de clareza, considera que como toda pesquisa, a investigação histórica tem os seus interesses e direcionamentos, conforme afirma Saviani:

“Consequentemente, o que provoca o impulso investigativo é a necessidade de responder a alguma questão que nos interpela na realidade presente. Obviamente isso não tem a ver com "presentismo" nem mesmo com o "pragmatismo". Trata-se da própria consciência da historicidade humana, isto é, a percepção de que o presente se enraíza no passado e se projeta no futuro." (SAVIANI, 2013, p. 4)

Seu método é "de caráter historiográfico", entendendo que procedeu uma história das ideias, em que adotou afinidades com as metodologias empregadas nos estudos da filosofia. Apresenta, sem embargo, um recorte de 354 referências bibliográficas, compondo-se de várias manifestações ideológicas de diversos autores, demonstrando com tal ecletismo, o problema teórico enfrentado no curso da investigação ao distinguir ideias educacionais de ideias pedagógicas.

Ao explicar a "configuração do projeto de pesquisa" que deu origem ao livro, o autor demonstra o rigor científico com o qual teceu os passos de suas investigações, revelando um padrão de excelência a ser tomado como referência pelos pesquisadores em geral. A revisão bibliográfica é feita de forma que vários pensadores de correntes teóricas diferentes "conversam" através da dissertação e das citações, ligados pela crítica argumentativa saviânica, questionando paradigmas contemporâneos e, com isso, configurando inovações no campo (SAVIANI, 2013, p. 2).

Esboça, portanto, linhas gerais do projeto, discorre sobre questões teóricas norteadoras como o conceito de "ideias pedagógicas" e a questão da periodização, bem como justifica ajustes feitos durante avaliações realizadas ao longo da execução da pesquisa. (SAVIANI, 2013, p. 6).

Dessa forma, com a formulação ao longo do texto de diversas hipóteses explicativas para questões ainda não elucidadas, Saviani indica a demanda para pesquisas complementares e incita novas investigações, fator com o qual tecemos a seguir um contraponto com a obra "0 signo de três".

\subsection{DO SIGNO DE TRÊS}

Esta obra de Umberto Eco e Sebeok, T. A. e col. (1983) é uma coletânea de diversos artigos construídos por autores de várias áreas do conhecimento, em que se é confrontado o método de investigação do Sherlock Holmes, personagem de Arthur Conan Doyle, e o argumento abdutivo de C. S. Pierce. Percebe-se, por meio do conhecimento interdisciplinar, através de análise racional, os processos metodológicos e científicos demonstrados na ficção.

Há de se registrar a influência do racionalismo cartesiano na civilização ocidental sustentada na tese da verdade infalível, a partir de um raciocínio matemático e dedutivo, tendo o conhecimento e a investigação para poucos privilegiados. Charles Sanders Pierce (1839-1914), entretanto, coloca-se na posição de desconstruir o método cartesiano, introduzindo aquilo que se poderia se chamar de "método alternativo", conceito original para a história filosófica. 
A maior contribuição do método pierceano refere-se à Filosofia (com o pragmatismo) e à Teoria da Comunicação. As tríades pierceanas, como ficaram conhecidas, incluem signo, objeto, interpretante, e os raciocínios sobre os quais versa a obra: dedução, indução e abdução, esta identificada como "pensamento conjectural". Assim, do ponto de vista da obra "O Signo de três", constituem-se como casos de pensamento conjectural as descobertas científicas, reconstituições históricas, interpretações de textos literários, investigações criminais e médicas. (ECO; SEBEOK, 1983, p. 14)

Torna-se claro na obra que Sherlock, muito embora apresente as suas deduções, estas não se figuram como induções, ao que se pretendia. Referem-se sim àquilo que Pierce nomeou de abduções, considerada como um terceiro tipo de inferência lógica, permeando a indução e dedução, métodos esses aceitos pela ciência tradicional. (ECO; SEBEOK, 1983, p. 60)

Assim sendo, Pierce defende a lógica do levantamento de hipóteses para ancorar os desafios da racionalidade, constituindo-se no caminho firme para a descoberta de novas verdades, mesmo de maneira aproximada e provisória. Através das hipóteses novas pode-se chegar a um novo ponto para enxergar o real, possibilitando experiências e experimentações novas, ressignificando a maneira de compreensão do problema pesquisado. (ECO; SEBEOK, 1983, p. 199)

O que se conclui a partir do entendimento dessa obra, voltando-se para a problemática a ser perseguida, é que uma pesquisa deve se afastar da "forma", a fim de se entender ou definir o objeto mediante o processo de formação das hipóteses exploratórias, permitindo a elaboração de um prognóstico geral, mesmo diante da possibilidade de resultados não tão bem-sucedidos.

Compreendemos que ao aproximar o raciocínio da compreensão ressignificada tendemos a contribuir para socializar o conhecimento, visto que se apresenta uma forma inovadora de produção de pesquisa científica, quebrando paradigmas tradicionais ao promover amplo alcance até chegar à utilização em sala de aula.

Sendo assim, em Saviani (2013) percebemos que podemos estabelecer uma ponte entre o pensamento exposto pierceano e o que foi desenvolvido em sua obra, em termos de metodologia, na formulação de hipóteses explicativas para as questões apresentadas ao longo do livro.

\section{CONCLUSÃO}

A singularidade como pista e o examinar do objeto tratado através da obtenção de dados testados e observados estabelece uma tensão que nos faz pensar sobre o "não existir" da verdade, mas a criação desta pela análise das fontes, do "decifrar" da realidade sob um paradigma conjectural, envolve a semiótica e a abdução nas premissas hipotéticas.

Em contrapartida e sobre isso, Saviani inova em sua obra apresentando, como desenvolvemos anteriormente, o método dialético-histórico, originando a sondagem de hipóteses explicativas para as questões levantadas ao longo da sua discussão sobre as ideias pedagógicas na história da educação brasileira, com o objetivo de socializar o conhecimento de modo que a educação brasileira, destacada a pública, ganhe com novas formas de se produzir pesquisa de qualidade a serem bem aproveitadas em sala de aula.

Torna-se claro ao associar as duas obras mencionadas o ponto de convergência, como sendo, o raciocínio abdutivo, inferindo a lógica daquilo que poderia ser, indo-se ao encontro de novas possibilidades, desafiando-se inclusive as normas existentes. Essa genialidade, que nos permite a possibilidade de inferirmos relações de seu método com métodos de outros campos de conhecimento, além de muitos outros atributos, torna Demerval Saviani (2013) destacado intelectual brasileiro da pós-modernidade.

\section{REFERÊNCIAS}

[1] Saviani, Dermeval. História das ideias pedagógicas no Brasil. 4aa ed. Campinas, São Paulo: Autores Associados, 2013.

[2] Eco, Umberto; Sebeok, Thomas A. (orgs.) O signo de três. São Paulo: Perspectiva, 1983. 


\section{Capítulo 22}

Políticas públicas de educação e ensino médio inovador: Contribuições ao debate

\section{Luzia Mônica Lima da Frota Araújo \\ Francisco Jucivânio Félix de Sousa \\ Ellis Regina Ferreira dos Santos}

Márcia Rejane Damasceno Dias

Resumo: 0 presente artigo tem como objetivo contribuir com o debate sobre as políticas públicas de educação para o Ensino Médio e se originou de uma pesquisa realizada em uma escola pública do Estado do Ceará, com o objetivo de compreender as reais necessidades dos atores escolares dessa unidade de ensino (alunos, professores, servidores, pais e gestores) alicerçada na perspectiva de consolidação da gestão democrática da escola pública que busca promover as ações contempladas no Projeto Ensino Médio Inovador (ProEMI) (Brasil, 2014). Para tanto, discute os desafios enfrentados por educadores e educandos do ensino médio, para possibilitar a efetivação de uma educação básica de qualidade. Contextualiza a escola em seus aspectos socioeconômicos e as dificuldades advindas de sua própria realidade enquanto comunidade. Parte da constatação de que a educação constitui um dos elementos mais importantes para o desenvolvimento econômico de um país ou região, pois tem por finalidade, preparar o cidadão para o exercício do trabalho e da cidadania, portanto, apresenta as principais políticas públicas educacionais voltadas a melhoria da educação no ensino médio que garanta o direito à educação para todos dessa etapa de ensino, que fomente a inclusão social, a diversidade étnica e cultural, favoreça a participação da comunidade na construção de um projeto consistente, através do Programa Ensino Médio Inovador (ProEMI), que integra as ações do Plano de Desenvolvimento da Educação (PDE), lançado em 2009, como estratégia do governo federal para a reestruturação dos currículos do Ensino Médio nos estados. É um estudo de natureza qualitativa que contempla investigações bibliográficas, documental e observação direta.

Palavras chave: Políticas Públicas Educacionais, Ensino Médio Inovador, Gestão democrática. 


\section{INTRODUÇÃO}

0 presente escrito apresenta os resultados de uma pesquisa realizada em uma escola pública do estado do Ceará, que tem como objetivo elaborar um plano de ação que vise atender as reais necessidades dos atores escolares (alunos, professores, servidores, pais e gestores). Referida investigação se alia a perspectiva de consolidação da gestão democrática na escola pública, buscando promover as ações contempladas no Projeto Ensino Médio Inovador (ProEMI) (Brasil, 2014).

Para tanto, discute os desafios enfrentados pelos educadores do ensino médio, no contexto da escola pública, para que se efetive uma educação básica de qualidade, partindo de uma perspectiva que apreende a educação e a escola em seus aspectos contraditórios, em face de contextos sociopolíticos e econômicos específicos.

Para fins de análise desse estudo nos ancoramos em uma visão histórica de educação, buscando relacionar as exigências impostas à escola, enquanto lócus privilegiado de repasse do saber sistematizado (SAVIANNI, 2003), como vinculadas a interesses específicos (políticos e econômicos) de cada época. Situamos, portanto, a compreensão vigente na sociedade atual, de que a educação constitui um dos elementos mais importantes para o desenvolvimento econômico de um país ou região, uma vez que tem por finalidade preparar o cidadão para o exercício do trabalho e da cidadania (Brasil, 1996).

Percebe-se, portanto, que a educação brasileira nas últimas décadas vem sendo alvo constante de preocupação política e foco do debate em âmbito acadêmico e social mais amplo, o que supõe compreender a interlocução do campo educativo com os interesses políticos. A exemplo disso se verifica, por exemplo, o Plano de Metas Compromisso Todos pela Educação que consiste em uma "conjugação dos esforços da União, Estados, Distrito Federal e Municípios, em regime de colaboração, das famílias e da comunidade, em proveito da melhoria da qualidade da educação básica (Brasil, 2012 p. 01)", assegurando o direito à educação para todos, permitindo uma ampla discussão sobre a inclusão social, a diversidade étnica e cultural, abrindo espaço para que a sociedade possa participar e debater essas diversas situações.

No que concerne mais especificamente ao Ensino Médio a Lei de Diretrizes e Bases da Educação - LDB no 9394/96, apresenta uma definição clara de essa etapa do ensino finaliza a Educação Básica e colabora para a construção da identidade do educando como pessoa humana, na qual poderá se inserir no mercado de trabalho ou dar continuidade aos estudos por meio do Ensino Superior. Assim, de acordo com a referida legislação, em sua seção IV, o ensino médio deverá ter como finalidade:

I- a consolidação e o aprofundamento dos conhecimentos adquiridos no ensino fundamental, possibilitando o prosseguimento de estudos;

II- a preparação básica para o trabalho e a cidadania do educando, para continuar aprendendo, de modo a ser capaz de se adaptar com flexibilidade a novas condições de ocupação ou aperfeiçoamento posteriores;

III- o aprimoramento do educando como pessoa humana, incluindo a formação ética e o desenvolvimento da autonomia intelectual e do pensamento crítico;

Nesse sentido este artigo tem como objetivo contribuir com o debate sobre as políticas públicas de educação para o Ensino Médio, a partir dos resultados parciais de uma pesquisa que apresenta os principais desafios enfrentados pelos educadores de uma escola pública do estado do Ceará, buscando identificar possibilidades concretas para a construção de ações e estratégias inovadoras para o ensino médio.

A escola pesquisada situa-se no município do Eusébio-CE, fazendo parte da Rede Estadual de Ensino e sob a abrangência da Coordenadoria Regional de Educação - CREDE 01- CE, que é composta por sete (07) municípios localizados na Região Metropolitana de Fortaleza: Aquiraz, Caucaia, Eusébio, Guaiúba, Itaitinga, Maracanaú e Pacatuba. A escola em questão localiza-se em um distrito do citado município e tem uma clientela de baixo poder aquisitivo cuja maioria é atendida pelos programas de geração de renda, oriundos de classe socioeconômica de baixo poder aquisitivo: trabalhadores assalariados ou subempregados, cujas famílias convivem com o drama da iminência do desemprego.

Como reflexo dessa realidade, percebe-se que em maioria, o corpo discente da escola não denota grandes perspectivas para um futuro promissor devido a uma baixa autoestima que apresenta. Por outro lado, o corpo docente, percebe-se também uma desmotivação por parte do corpo docente pelo sentimento 
de impotência devido a atual realidade vivida pelos adolescentes que frequentam a escola. Percebe-se, portanto, que ambos os grupos, denotam falta de vontade de participar dos projetos, das reuniões e das atividades que são planejadas para acontecer na escola.

\section{METODOLOGIA}

Essa pesquisa consiste em um estudo de natureza qualitativa, que contempla investigações de cunho bibliográfico, documental e de campo. Como procedimento metodológico para incursão no campo de investigação, privilegiamos a pesquisa ação, a fim de possibilitar, através, de dados obtidos, a formulação de novas questões/pressupostos para pesquisas futuras. O levantamento dos dados foi realizado in loco, por meio de observações na instituição alvo da pesquisa, sendo realizadas no período de Março de 2015.

0 referencial teórico utilizado se ancora em Veiga (2003), Neubauer (2001), as autoras dialogam que um processo de vivência democrática nas escolas somente acontecerá quando todos os segmentos que compõem a comunidade escolar e acadêmica participam, com compromisso, acompanhamento e, principalmente, nas escolhas das trilhas que a instituição irá seguir.

As análises deste estudo ainda podem ser consideradas como resultados parciais, de uma pesquisa ainda em desenvolvimento, e apontam para uma diversidade de questões que demandam um maior tempo de análise sobre a complexa problemática na qual se inserem as políticas públicas de educação no Brasil.

\section{RESULTADOS E DISCUSSÃO}

O debate sobre as Políticas Públicas Educacionais voltadas a melhoria da educação no ensino médio, requer uma apreciação mais detida de algumas leis específicas que merecem ser citadas aqui, tais como: o Fundo de Manutenção e Desenvolvimento da Educação Básica e de Valorização dos Profissionais da Educação (FUNDEB); a ampliação do Programa Dinheiro Direto na Escola (PDDE) para o atendimento de escolas de Ensino Médio, que vem buscando promover ações que possam minimizar as dificuldades existentes. Ainda com foco no ensino médio, têm-se o Programa Ensino Médio Inovador (ProEMI), que integra as ações do Plano de Desenvolvimento da Educação (PDE), lançado em 2009, como estratégia do governo federal para a reestruturação dos currículos do Ensino Médio nos estados.

De acordo com as diretrizes para o Programa Ensino Médio Inovador, esse tem como objetivo,

[...] apoiar e fortalecer o desenvolvimento de propostas curriculares inovadoras nas escolas de Ensino Médio, ampliando o tempo dos estudantes na escola e buscando garantir a formação integral com a inserção de atividades que tornem o currículo mais dinâmico, atendendo também às expectativas dos estudantes do Ensino Médio e às demandas da sociedade contemporânea (BRASIL, 2008, p.83).

Esse documento define um Plano de Ação Pedagógica (PAP) cujos efeitos incidem diretamente no currículo, que possibilita a aquisição de materiais pedagógicos, laboratórios, investimento em formação de professores, visitas de estudos dos estudantes, entre outras atividades que fazem parte de uma formação comprometida com a promoção do conhecimento, a pesquisa e as ações culturais. Com amparo nessa legislação específica que denota um cuidado especial para essa etapa do ensino, o foco de nosso debate recai sobre as possibilidades concretas de se construir um Plano de Ação para que a escola possa adaptar suas ações com as temáticas do ProEMI, acima mencionado.

Nessa perspectiva são apresentadas aqui algumas sugestões para implementação de ações a serem executadas no sentido de fortalecer a colaboração entre todos os atores envolvidos na escola:

Promover oficinas para professores, alunos e pais a cerca da elaboração do Projeto Político Pedagógico (PPP) da escola, pois somente teremos a participação efetiva de todos os servidores, professores, pais e comunidades quando os mesmos tiverem a consciência dos seus direitos e deveres, portanto, participar das ações da escola precisa ser motivado por atitudes como as oficinas propostas.

-

Atualização do Projeto Político Pedagógico (PPP) da escola que deverá dialogar com todos os problemas e as possíveis soluções para que de forma democrática e participativa, no mínimo, ao final de cada ano letivo ou quando se fizer necessário, de modo a ajustá-lo às novas necessidades e demandas da comunidade escolar. 
Estimular a criação de projetos interdisciplinares, envolvendo professores, alunos, por exemplo, Projeto Cinema e vídeo na escola, Grupo de dança e teatro, práticas esportivas diversificadas, clube de ciência e matemática.

Essas ações, ao serem desenvolvidas na escola precisam estar alinhadas com a realidade local em que a escola esteja inserida, visando alcançar os objetivos propostos relacionados ao currículo da escola e das diretrizes estabelecidas pelo ProEmi, ou seja, o foco em ações elaboradas a partir das áreas de conhecimento, conforme proposto nas Diretrizes Curriculares Nacionais para o Ensino Médio, ações que articulem os conhecimentos à vida dos estudantes, seus contextos e realidades.

\section{CONCLUSÃO}

Pode-se constatar que existe uma preocupação social e política com o sistema de ensino no Brasil, que está passando por adaptações sistemáticas, entre elas, a ampliação da carga horária e da jornada diária das crianças e jovens, a busca pela manutenção desses jovens na escola e a reestruturação do Ensino Médio para adequá-lo às novas demandas do mundo do trabalho, que se apresentam como novos desafios, posteriores à universalização do acesso à escola.

Algumas ações podem ser projetadas em busca desta construção do PPP coletivo, tais como: o fortalecimento dos órgãos colegiados da escola, tais como o Conselho Escolar, o Grêmio Estudantil, a Unidade Executora, o Conselho de Pais. Somente após o fortalecimento dessa ação teremos a possibilidade de construir um espaço de debates e interações para que o grupo possa compartilhar angústias e solucionar as problemáticas a serem enfrentadas.

\section{REFERÊNCIAS}

[1] Brasil. Lei de Diretrizes e Bases da Educação Nacional, Lei 9394/96, de 20 dez. 1996 Brasília, DF, p. 1. Disponível em: <www.mec.gov.br>. Acesso em: 20 de outubro 2014.

[2] Compromisso Todos Pela Educação. Disponivel em: http://portal.mec.gov.br/arquivos/pdf/diretrizes_compromisso.pdf. Acesso em 19 de outubro de 2014. Brasília: 2012.

[3] Secretaria de Educação Básica. Programa: Ensino Médio Inovador Documento Orientador. Brasília: 2014.

[4] Secretaria de Educação Básica. Programa: Ensino Médio Inovador Documento Orientador. Brasília: 2008.

[5] Neubauer, Rose et all. Ensino médio no Brasil: uma análise de melhores práticas e de políticas públicas. Revista Brasileira de Estudos e Pedagogia. Brasília, v. 92, n. 230, p. 11- 33, jan./abr. 2011. Acesso em: 20 de Janeiro de 2015.Disponível: < http://rbep.inep.gov.br/index.php/RBEP/article/viewFile/1822/1378>.

[6] Saviani, D. Pedagogia Histórico-Crítica. 8. ed. Campinas, SP: Autores Associados, 2003.

[7] Veiga, I.P.A. Inovações e projeto político-pedagógico: uma relação regulatória ou emancipatória? Caderno Cedes, Campinas, v. 23, n. 61, p. 267-281, dezembro 2003 267. Acesso em 16 de janeiro de 2015. Disponível em $<$ http://www.cedes.unicamp.br.> 


\section{Capítulo 23}

\section{A influência do Neoliberalismo nas políticas públicas para o ensino integral no Estado de São Paulo}

\section{Ronaldo Costa Barbosa \\ Raimunda Abou Gebran}

Resumo: 0 presente trabalho tem por objetivo analisar a influência do neoliberalismo sobre as políticas públicas no estado de São Paulo a partir da década de 1990, em especial no que diz respeito às propostas de extensão do tempo de permanência na escola, frequentemente compreendidas como ensino de tempo integral - Escola de Tempo Integral (ETI) e Programa Ensino Integral (PEI). Para tanto, realizou-se uma revisão bibliográfica dos documentos norteadores dos programas apoiados nas reflexões de Rossi (2011), Haddad (2008) e Freitas (2007). Em um primeiro momento analisou-se a influência do neoliberalismo na elaboração de políticas públicas no Brasil e no estado de São Paulo a partir das proposições do Consenso de Washington. Na sequência, refletiu-se sobre o impacto de tais políticas para o programa "Educação compromissos de São Paulo", proposto pelo governo paulista em 2011 e seus reflexos para a organização das escolas. Por fim, realizou-se uma análise crítica do PEI procurando desvelar as peculiaridades do programa. Após as análises, concluiu-se que apesar da continuidade no poder no estado de São Paulo por mais de 20 anos do mesmo grupo político, as ações promovidas pelo poder público não apresentaram continuidade e se mostraram fiéis às determinações de organismos internacionais, em especial aos do Banco Mundial. 0 Programa Ensino Integral mostra-se como um espaço diferenciado para a ação docente e o desenvolvimento do protagonismo juvenil entre os jovens, entretanto, por ser uma ação recente, carece de investigações que desvelem se as proposições se concretizam no cotidiano destas escolas, viabilizando o trabalho pedagógico diferenciado e contribuindo para a melhoria do ensino oferecido. 


\section{INTRODUÇÃO}

O Programa Ensino Integral (PEI) implementado pelo governo paulista a partir de 2012 reascendeu discussão sobre as políticas públicas no estado de São Paulo. Ao propor um modelo diferenciado, com dedicação exclusiva dos docentes a uma única unidade escolar e remuneração superior à dos demais professores da rede, o governo paulista reafirmou a implantação das políticas neoliberais que vinham sendo introduzidas na rede desde a década de 1990.

Dessa forma, o presente artigo procura compreender a influência das ideias neoliberais na formulação das políticas públicas brasileiras e no estado de São Paulo, em especial as que se relacionam com a extensão do tempo de permanência do aluno na escola, generalizadas como escolas de tempo integral.

Desvelar as intencionalidades na elaboração de reformas educacionais é de extrema importância para compreender a ação docente, uma vez que as políticas geralmente são autóctones e impostas aos países unilateralmente, sem considerar as especificidades da ponta final do processo educativo: o docente em sala de aula com seus alunos.

A introdução de metas e prazos que devem ser perseguidos pelas escolas a fim de garantir o sucesso na aprendizagem dos alunos cria uma política de responsabilização e meritocracia no ambiente escolar. A divulgação de rankings de desempenho acaba por gerar uma separação entre as escolas e uma busca desenfreada por melhoria nos índices, o que nem sempre se traduz em melhoria na aprendizagem dos alunos. Em outros termos:

[...] deixada à lógica do mercado, o resultado esperado será a institucionalização de escola para ricos e escola para pobres (da mesma maneira que temos celulares para ricos e para pobres). As primeiras canalizarão os melhores desempenhos, as últimas ficarão com os piores desempenhos. As primeiras continuarão sendo as melhores, as últimas continuarão sendo as piores. Mas o sistema terá criado um corredor para atender as classes mais bem posicionadas socialmente, o que será, é claro, atribuído ao mérito pessoal dos alunos e aos profissionais da escola (FREITAS, 2007, p. 969).

A própria execução do PEI realça esse viés: ao garantir o acesso a apenas uma parcela dos docentes à condições menos precárias do que as verificadas nas escolas da rede, cria-se um separação entre os "privilegiados" - que detém jornada diferenciada, dedicação a uma única escola e salários significativamente superior aos demais - e o restante desta, que é exposta a condições precárias de trabalho, salários insuficientes, salas superlotadas e falta de materiais e recursos didáticos.

Outro fator decisivo para a compreensão da atual situação na qual se encontra a grande maioria das escolas públicas paulistas é a descontinuidade de políticas adotadas a despeito da permanência no poder do mesmo grupo político há mais de vinte anos. Dessa forma, analisaremos em especial as políticas relacionadas ao ensino de tempo integral: a adoção e a posterior despriorização da Escola de Tempo Integral (ETI) e a implementação do Programa Ensino Integral (PEI).

Pretendemos, assim, contribuir para uma reflexão a respeito das propostas de melhoria na qualidade do ensino público paulista, refletindo sobre as políticas adotadas bem como sobre as influências que determinam tais políticas. Consideramos que o objetivo final do sistema educativo deva ser garantir a aprendizagem do aluno, visando à emancipação cidadã e a construção do ser social e crítico.

\section{DESENVOLVIMENTO}

\subsection{AS POLÍTICAS NEOLIBERAIS E AS REFORMAS EDUCACIONAIS BRASILEIRAS}

No início da década de 1990, a Unesco - patrocinada pelo Banco Mundial - realizou na cidade de Jomtien, na Tailândia, a Conferência Mundial sobre Educação para Todos. Este evento reafirmou a necessidade urgente de mudanças nos sistemas educacionais, em um momento onde o capitalismo incorporava e amadurecia as ideias neoliberais. A educação passou a ser entendida como via para o desenvolvimento econômico, o que colocou em cheque as políticas até então adotadas pelos países em desenvolvimento, abrindo caminho para as mudanças propostas por instituições estrangeiras e mediadas pelo Banco Mundial (ROSSI, 2011). 
Nesse sentido:

com um discurso falso sobre qualidade e combate a pobreza, acesso universal a educação básica, assim como utilização de termos do mundo empresarial como metas, flexibilidade e resultados, tal conferência vem para institucionalizar e legitimar a influência dos organismos multilaterais como o próprio Banco Mundial na soberania dos países pobres. Portanto, há um discurso de satisfação de necessidades de aprendizagem, com uma abertura, falsamente qualificada como democrática, para a construção e difusão de parâmetros mundiais, ditos educacionais, mas que visam fundamentalmente formar trabalhadores polifuncionais, adaptáveis às diversas mudanças do mercado, ideologicamente subordinado a perspectiva da resolução individual de seus problemas e adaptados a esfera da reprodução ampliada do capital. (ROSSI, 2011, p. 30).

Assim, conforme propõe Dale (2004), no lugar de construir um projeto educacional que atendesse às reais necessidades das populações locais, garantindo o acesso das camadas populares à informação e ao conhecimento científico, e possibilitando, assim, o desenvolvimento humano e econômico, o que se verificou a partir da Conferência foi a adoção de uma "agenda globalmente estruturada para a educação", que visava utilizar a educação como meio para atingir os objetivos do capital, e não para a construção de uma sociedade mais igualitária.

Segundo o Banco Mundial, a crise pela qual passavam os sistemas educacionais dos países emergentes não era uma crise de acesso, mas de gerenciamento, explicada pela ineficiência do Estado em administrar tais sistemas. O Banco defendia que somente reformas que promovessem mecanismos de regulação da eficiência, da produtividade e da eficácia poderiam trazer "qualidade" aos sistemas educacionais, reafirmando a ideia empresarial na administração escolar. Tais justificativas deram legitimidade para as ações reformistas na América Latina. Nesse sentido, a "educação deixa de ser um direito de cidadania para se tornar uma mercadoria, onde os educandos passam a ser consumidores" (ROSSI, 2011, p. 31).

Outra profunda mudança promovida pelo Banco Mundial diz respeito à visão de educação. Para essa instituição, a educação é encarada como prestação de serviço à comunidade e não como um direito de todos à transmissão e troca de saberes, cultura e valores. Assim, é função dos professores oferecer o mais eficiente serviço a seus "clientes", os pais. O fortalecimento da comunidade como "fiscais" do serviço oferecido pelos professores passou a ser um dos pilares para a melhoria da educação (HADDAD, 2008).

No cenário brasileiro, a influência neoliberal promoveu alterações profundas no campo institucional e na legislação, especialmente com a criação da Lei de Diretrizes e Bases da Educação (LDB/9.394/96), dos Parâmetros Curriculares Nacionais (PCNs) para o Ensino Fundamental (1997 - primeiro e segundo ciclos, 1998 - terceiro ciclo e médio). No estado de São Paulo, efetivou-se plenamente as políticas e orientações do Consenso de Washington, tanto no campo econômico como nas reformas educacionais.

\subsection{O PROGRAMA ‘EDUCAÇÃO: COMPROMISSO DE SÃO PAULO’ E O ENSINO INTEGRAL}

Com início do segundo mandato de Geraldo Alckmin no governo de São Paulo em 2011, Herman Voorwald, então reitor da Universidade Estadual Paulista (Unesp) é convidado para assumir a Secretaria de Educação. Logo no início da gestão, o secretário promoveu uma série de encontro nas Diretorias Regionais de Ensino a fim de dialogar com a rede sobre as necessidades para a melhoria da qualidade do ensino.

Como resposta a estas visitas, foi lançado o programa 'Educação - Compromisso de São Paulo' que

[...] estabelece um pacto com a sociedade em prol da educação. Entre suas principais metas, o programa pretende fazer com que a rede estadual paulista figure entre os 25 melhores sistemas de educação do mundo nas medições internacionais, além de posicionar a carreira de professor entre as dez mais desejadas do Estado. O programa foi construído em conjunto com educadores e funcionários da rede estadual paulista. Ao longo de encontro com milhares de profissionais que atuam diariamente na rotina de escolas e salas de aula, formatou-se uma proposta com base nas demandas e anseios dos educadores (SÃO PAULO, 2011).

Organizado em cinco pilares principais, conforme a Figura 1, o programa lança a audaciosa meta de posicionar a rede entre as melhores do mundo e de alavancar a carreira docente entre as mais atrativas para os jovens que ingressam nas universidades. 
Figura 1 - Pilares do programa Educação - compromisso de São Paulo.

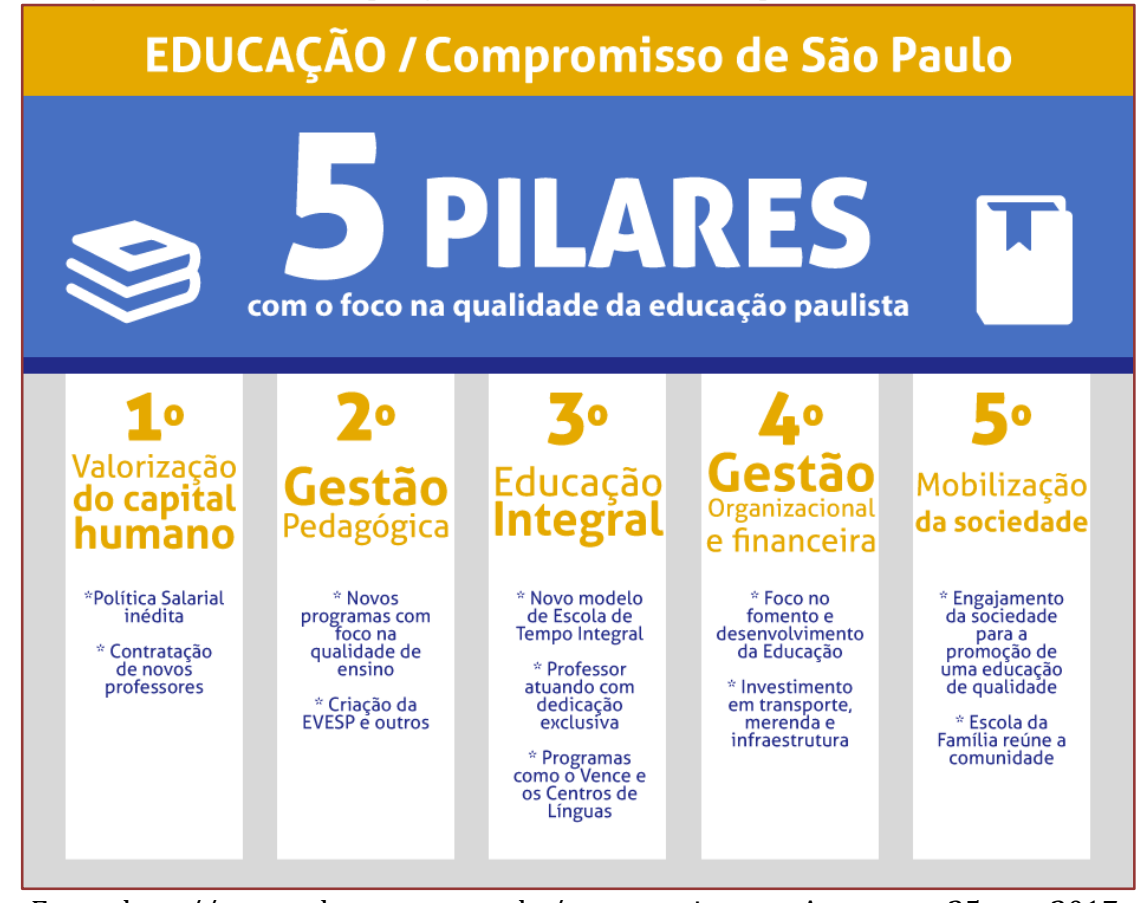

Fonte: http://www.educacao.sp.gov.br/compromisso-sp. Acesso em 25 mar 2017.

O programa propõe, em seu terceiro pilar, um novo modelo de escola em tempo integral. É importante ressaltar que nos anos 2000, foi instituído através da Resolução SE no 89 de 11 de dezembro de 2005, o projeto Escola de Tempo Integral (ETI) em algumas unidades de Ensino Fundamental da Secretaria do Estado de Educação de São Paulo (SEE-SP). O projeto objetivou prolongar o tempo de permanência na escola de cinco para nove horas diárias, visando ampliar as possibilidades de aprendizagem dos alunos com a introdução de Oficinas Curriculares (SÃO PAULO, 2006).

Pesquisas que investigaram esse modelo de escola (CASTRO; LOPES, 2011) apontaram algumas limitações quanto à proposta, das quais destacamos as seguintes:

a) a jornada diária foi ampliada, porém sem alteração da organização do tempo e do espaço escolar e sem o desenvolvimento do protagonismo juvenil.

b) não há um consenso entre a comunidade escolar sobre o conceito de Educação Integral, repercutindo no processo educacional.

c) a concepção filosófica de Educação Integral da SEE-SP não encontrava reflexos na prática educativa.

Corroborando com essas conclusões, afirma-se que:

[...] o Currículo engloba conteúdo e forma de abordagem - conhecimento e métodos de ensino -, numa condição marcada pelas condições do contexto em que se desenvolve. Causa estranhamento pensar numa ampliação de tempo escolar sem que, previamente, se enfrente a reflexão sobre o currículo nestas condições e qual o impacto das novas configurações de tempos sobre o trabalho da escola, afirmando que se busca formar pessoas aptas a exercerem a cidadania e buscando a mudança tão somente por meio da adoção de "procedimentos metodológicos inovadores", tal como nas diretrizes da CENP [...] (GALIAN; SAMPAIO, 2012, p. 404-405); 
Dessa forma, o projeto mais colaborou para minimizar as mazelas sociais de áreas socialmente mais excluídas (regiões com menor IDH) do que com a melhoria do ensino ofertado e, gradativamente, com as mudanças de gestão,

[...] o projeto deixou de ser a menina dos olhos da Secretaria. As capacitações, paulatinamente, deixaram de ocorrer para os supervisores e assistentes técnicos-pedagógicos em São Paulo, acarretando um fato similar na Diretoria de Ensino para professores e professores coordenadores (CASTRO; LOPES, 2011, p. 278).

Logo, com a proposta de um "novo modelo de escola de tempo integral", o modelo anterior é colocado em segundo plano nas políticas de investimentos da secretaria.

Inicialmente, ingressaram no PEI 16 escolas de Ensino Médio, destacando o primeiro diferencial em relação ao programa ETI, que atendia apenas a escolas de Ensino Fundamental. O novo modelo previa a adequação do espaço físico, com a implantação de laboratórios de secos e molhados, laboratório de informática, sala de multimeios, sala de leitura e refeitório. Além da reestruturação física, o programa também prevê uma reestruturação no quadro de profissionais.

As escolas que aderiram ao programa não comportavam a locação de cargos, logo todos os profissionais foram removidos para a unidade escolar mais próxima. 0 ingresso docente nas escolas do programa ocorre por meio de um processo seletivo, organizado em entrevistas e análise do projeto educacional proposto com o objetivo de identificar os profissionais que possuem perfil adequado ao novo modelo (SÃO PAULO, 2012).

Outro diferencial do programa é a exigência de adesão ao RDPI (Regime de Dedicação Plena e Integral), no qual o docente deve dedicar 40 horas semanais a atividades desenvolvidas na escola, não podendo possuir nenhum vínculo empregatício durante o horário de funcionamento da escola. Ao aderir ao RDPI o docente faz jus à Gratificação de Dedicação Plena e Integral, referente à $75 \%$ sobre o salário-base do docente (SÃO PAULO, 2012).

Em 2013, o programa é expandido para 53 novas escolas de Ensino Fundamental - Anos Finais e Ensino Médio; em 2014 mais 113 escolas aderem ao programa e em 2015 mais 58 escolas. Em 2015 um piloto do programa é implantado em 17 escolas de Ensino Fundamental - Anos Iniciais. Atualmente o programa conta com 297 escolas que atendem cerca de 91 mil alunos ${ }^{18}$.

O PEI apresenta-se como um novo modelo de escola, que oferece condições diferenciadas para a composição da jornada docente e ações mais atrativas para os jovens, como a organização de clubes juvenis e a escolha de disciplinas eletivas. Por outro lado, tal modelo confirma os preceitos de responsabilização, meritocracia e privatização. Sobre as políticas de responsabilização:

há de se reconhecer as falhas nas escolas, mas há de se reconhecer, igualmente, que há $\mathrm{f}$ alhas nas políticas públicas, no sistema socioeconômico, etc.. Portanto, esta é uma situação que, à espera de soluções mais abrangentes e profundas, só pode ser resolvida por negociação e responsabilização bilateral: escola e sistema. Os governos não podem "posar" de grandes avaliadores, sem olhar para seus pés de barro, para suas políticas, como se não tivessem nada a ver com a realidade educacional do país de ontem e de hoje.

A estratégia liberal é insuficiente porque responsabiliza apenas um dos pólos: a escola. E o faz com a intenção de desresponsabilizar o Estado de suas políticas, pela responsabilização da escola, o que prepara a privatização. Para a escola, todo o rigor; para o Estado, a relativização "do que é possível fazer" (FREITAS, 2007, p. 975).

Outro ponto a ser considerado é a oferta de condições diferenciadas para apenas uma pequena parcela da rede. Se este modelo é compreendido como uma "escola de qualidade", ela não é para todos. Apenas umas partes dos professores podem optar por aderir ao RDPI e compor a sua jornada com dedicação exclusiva a uma única escola e apenas uma parte dos alunos da rede podem ter a opção de estudar em uma escola com uma infraestrutura melhor adaptada aos seus anseios. Neste sentido, "a palavra de ordem da qualidade encerra também um segundo significado: não o melhor (em vez do mesmo ou de menos) para todos, mas para uns poucos e igual ou pior para os demais" (ROSSI, 2011, p. 32).

18 http://www.educacao.sp.gov.br/ensino-integral. Acesso em: 25 mar 2017. 
A visão empresarial imposta pelo neoliberalismo via agências internacionais torna-se pleno no PEI, como, por exemplo, no seu modelo de gestão, uma vez que:

o modelo de gestão escolhido para as Escolas Estaduais de Ensino Fundamental e Médio de Tempo Integral é denominado de Tecnologia de Gestão Educacional (TGE). A finalidade desse modelo é alcançar uma gestão eficaz, na busca por garantir que os objetivos estabelecidos sejam cumpridos e alcançados. 0 aspecto indissociável a essa suposta eficiência se traduz em liderar e conduzir o processo de gestão, aplicando de forma correta as técnicas e metodologias apresentadas pela SEE/SP. Nessa perspectiva, emerge o ciclo planejar, desenvolver, controlar e agir corretivamente (PDCA, em inglês, Plan, Do, Check, Act) (...). 0 ciclo PDCA foi desenvolvido na década de 1930 nos Estados Unidos, pelo físico e engenheiro Walter Shewhart e, posteriormente, propagado por William Edwards Deming, estatístico norte-americano, ambos conhecidos pela dedicação ao desenvolvimento de processos de controle estatístico da qualidade. (LOPES; SERRA, 2014, p. 88).

Desta forma, o diretor assume o papel de líder do processo organizacional, sendo responsável pela elaboração dos principais documentos que nortearão as ações dentro da escola.

Por ser um programa de implantação recente, que teve início em 2012, há ainda uma escassez de pesquisas científicas que avaliem se a adoção profunda da visão mercadológica nas políticas educacionais resultou em melhoria dos indicadores das avaliações externas, finalidade principal das ações do programa.

\section{CONSIDERAÇÕES FINAIS}

Após a crise de superprodução dos anos 1970 e a falência do welfare state, as políticas neoliberais ganharam espaço como doutrina político-econômica nos países centrais do sistema capitalista. Emergiu também a necessidade de reverter a estagnação econômica verificada nas economias emergentes, que se mostravam como mercados fundamentais para a manutenção da ordem econômica.

Tal estagnação colocava em risco a economia mundial, pois, altamente endividados, os países emergentes viram-se envoltos em crises fiscais e políticas que necessitavam de ações imediatas. Nesse sentido, o Consenso de Washington elaborou determinações a serem cumpridas por esses países visando restabelecer a ordem econômica e fiscal.

Nesse cenário de reorganização, a educação é elencada pelo Banco Mundial como grande responsável pela erradicação da pobreza e por garantir a recomposição econômica. As ações adotadas pelos governos emergentes foram consideradas insuficientes para suprir as necessidades de acesso universal e de qualidade para a população geral no sistema educacional.

As reformas promovidas pelos governos, em especial o brasileiro e o paulista, durante os anos 1990 foram fortemente influenciadas pelos ideais neoliberais, que visavam garantir uma gestão mais eficiente dos recursos destinados ao setor.

Sob o discurso da melhoria na qualidade do ensino, uma visão mercadológica e empresarial passou a ser implantada na educação, com o estabelecimento de metas e prazos a serem cumpridos, visando, dessa forma, garantir o aprendizado dos alunos.

No estado de São Paulo, tais políticas neoliberais encontram terreno fértil para se desenvolver, com ações claramente influenciadas por organismos internacionais, como o programa Educação - compromisso de São Paulo.

O aumento das escolas em tempo integral, primeiramente com o programa ETI e posteriormente com o PEI reforçam a aplicação das políticas no território. Especificamente em relação ao PEI, a visão empresarial é claramente destacada, com a escola sendo observada como uma grande empresa, onde o diretor é o líder da equipe visando garantir o sucesso no alcance das metas estabelecidas pela SEE-SP.

Se por um lado, a princípio, o PEI oferece melhores condições para a ação docente na escola, com carga horária diferenciada e salário superior ao restante da rede, por outro lado a ação retira este direito da maioria da rede, garantindo apenas a uma pequena parcela dos professores e alunos o acesso a condições menos precárias para o desenvolvimento das ações pedagógicas. 
Outro agravante verificado no estado de São Paulo é que, apesar do mesmo grupo político manter-se no poder há mais de vinte anos, ainda assim não foram estabelecidas políticas que realmente produzissem mudanças profundas na aprendizagem dos alunos. Todas as mudanças de governo foram acompanhadas de reformulações das políticas existentes, rompendo a continuidade dos programas e ações e descaracterizando o caráter público dos investimentos.

O PEI mostra-se como uma alternativa à precarização verificada nas escolas da rede estadual, tanto em relação à carreira docente como em relação às expectativas dos alunos. Resta investigar o programa a fim de compreender se as ações encontram viabilidade prática para a aprendizagem dos alunos e aguardar para que as próximas gestões ampliem e perpetuem boas práticas para as demais escolas da rede.

\section{REFERÊNCIAS}

[1] Castro, Adriana de; Lopes, Roseli Esquerdo. A escola de tempo integral: desafios e possibilidades. Ensaios: Avaliação e Políticas Públicas em Educação, Rio de Janeiro, v. 19, n. 71, p.259-282, abr./jun. 2011. Disponível em: < http://www.scielo.br/pdf/ensaio/v19n71/a03v19n71.pdf>. Acesso em 7 jun. 2017.

[2] Dale, Roger. Globalização e Educação: demonstrando a existência de uma "Cultura Educacional Mundial Comum" ou localizando uma agenda globalmente estruturada para a educação? Educ. Soc., Campinas, vol. 25, n. 87, p. 423-460. Disponível em: < http://www.scielo.br/pdf/es/v25n87/21464.pdf>. Acesso em 7 jun. 2017.

[3] Freitas, Luiz Carlos de. Eliminação adiada: o ocaso das classes populares no interior da escola e a ocultação da (má) qualidade do ensino. Educ. Soc., Campinas, v. 28, n. 100, p. 965-987, Oct. 2007. Disponível em: < http://repositorio.unicamp.br/jspui/bitstream/REPOSIP/24527/1/S0101-73302007000300016.pdf>. Acesso em 7 jun. 2017.

[4] Galian, Cláudia Valentina Assumpção; Sampaio, Maria das Mercês Ferreira. Educação em Tempo Integral: implicações para o currículo da escola básica. Currículo Sem Fronteiras, Rio de Janeiro, v. 12, n. 2, p.403-422, maio/ago. 2012. Quadrimestral. Disponível em: < http://www.curriculosemfronteiras.org/vol12iss2articles/galiansampaio.pdf >. Acesso em 7 jun. 2017.

[5] Haddad, Sérgio. Banco Mundial, OMC e FMI: o impacto nas políticas educacionais. São Paulo: Cortez, 2008.

[6] Lopes, Maria Fernanda Arraes; Serra, Maria Helena Moreira Dias. Escolas de tempo integral no estado de São Paulo: características e princípios que norteiam o Programa de Ensino Integral. Imagens da Educação, [s.l.], v. 4, n. 3, p.85-91, 19 nov. 2014. Universidade Estadual de Maringá. Acesso em 07 jun. 2017. doi: http://dx.doi.org/10.4025/imagenseduc.v4i3.25748

[7] Rossi, Murilo. A nova proposta curricular do ensino de geografia na rede estadual de São Paulo: um estudo. 2011. 206 f. Dissertação (Mestrado) - Curso de Mestrado em Geografia Humana, Departamento de Geografia, Universidade de São Paulo, São Paulo, 2011.

[8] São Paulo (Estado). Secretaria da Educação. Diretrizes Curriculares da Escola de Tempo Integral: tempo e qualidade. São Paulo: Imprensa Oficial do Estado, 2006.

[9] _. A educação paulista entre as melhores do mundo.2011. Disponível em: <http://www.educacao.sp.gov.br/compromisso-sp>. Acesso em: 25 mar. 2017.

[10] _. Diretrizes do Programa de Ensino Integral. São Paulo: SEE, 2012. Disponível em: http://www.educacao.sp.gov.br/a2sitebox/arquivos/documentos/726.pdf. Acesso: 21 mar. 2017. 


\section{Capítulo 24}

\section{Qualidade na educação básica: Benefício em todos os}

níveis escolares

\section{Ivo José Both \\ Patrícia Beraldo}

Resumo: Este trabalho é fruto de pesquisa bibliográfica com o objetivo de identificar a qualidade da educação de forma genérica, mas, em especial a educação básica. 0 trabalho foi realizado com base em consulta em referencial teórico. Entre outros autores, são estes alguns dos consultados: MORAN (2013), GENTILI (1995) e PIMENTA (1999). As representações e conceitos, sobre a definição de uma Educação de Qualidade variam no tempo e espaço, principalmente se acatarmos as mudanças mais recentes da sociedade atual, respeitando as condições de cada sistema de ensino. Uma das finalidades da educação é a formação plena do ser humano bem como o desenvolvimento de sua essência, com ser independente autônomo e pensante, sendo capaz de conviver em sociedade, desta forma o conceito de qualidade deve ser arrojado. Cada vez mais a questão da formação de professores assume importância ante as exigências que são colocadas diante da educação básica de crianças e de adolescentes na sociedade contemporânea. Os programas de formação continuada que são oferecidos no território nacional são baseados na legislação brasileira, no campo educacional, com destaque para a LDB e para o Plano Nacional da Educação (PNE), manifestam a importância das descrições de padrões de qualidade de ensino. Alguns dos resultados são os seguintes: a qualidade é uma variável necessária no contexto educacional, mas possui conotações variadas muito em função da formação de acadêmica de quem a qualifica; a educação básica necessita servir de suporte básico à qualidade em todos os níveis escolares; melhorar a qualidade da educação básica constitui um desafio nacional.

Palavras-chave: Qualidade. Educação básica. Educação. Formação de professores. 


\section{INTRODUÇÃO}

O tema da qualidade da educação tem provocado um contínuo debate entre os estudiosos e gestores políticos acerca nas perspectivas que definem uma educação de 20855 qualidade. Considero que seja um tema abrangente, arrojado e mobilizador de diferentes interesses.

Para compreender o termo qualidade em educação, faz-se necessário voltar à teoria da educação e esclarecer o que se espera de um processo de educação. "A educação precisa ser fonte de mudança e libertação, pronuncia Freire; onde a educação libertária seja o fulcro do trabalho dos educadores, em vista de vivermos em uma sociedade intensamente cambiante e dramaticamente contraditória" (FREIRE, 1979 apud OLIVEIRA, 2011).

Ou ainda:

Educar e educar-se, na prática da liberdade, é tarefa daqueles que pouco sei - por isto sabem que sabem algo e podem assim chegar, a saber, mais - em diálogo com aqueles que, quase sempre, pensam que nada sabem, para que estes, transformando seu pensar que nada sabem em saber que pouco sabe, possam igualmente saber mais. (FREIRE, 1979 apud OLIVEIRA, 2011).

Promover a melhoria da qualidade da educação básica é hoje o principal desafio do Brasil em no que dizem respeito às políticas sociais. Extremamente necessário reconhecer o valor que a educação possui, porém é imprescindível ter um resultado detalhado das circunstâncias dos problemas para que se definam metas, estratégias e políticas que possam melhorar o quadro atual. 0 governo federal definiu as metas e prazos para que a educação alcance o padrão médio analisados nos países mais desenvolvidos. É necessário que essas políticas não sofram mudanças com as trocas de governos, e que sigam os objetivos e façam cumprir os prazos.

Promover a melhoria da qualidade da educação básica é hoje o principal desafio do Brasil em no que dizem respeito às políticas sociais. Extremamente necessário reconhecer o valor que a educação possui, porém é imprescindível ter um resultado detalhado das circunstâncias dos problemas para que se definam metas, estratégias e políticas que possam melhorar o quadro atual. 0 governo federal definiu as metas e prazos para que a educação alcance o padrão médio analisados nos países mais desenvolvidos. É necessário que essas políticas não sofram mudanças com as trocas de governos, e que sigam os objetivos e façam cumprir os prazos.

As representações e conceitos, sobre a definição de uma Educação de Qualidade variam no tempo e espaço, principalmente se acatarmos as mudanças mais recentes da sociedade atual, respeitando as condições de cada sistema de ensino.

Nos últimos anos, as políticas educacionais mostram-se preocupadas com a qualidade da educação. Mas o que é qualidade em educação?

Para GENTILI (1995, p. 177), o assunto da qualidade não pode ficar escondido dentro do tema da democratização do ensino. Ela interpela a democracia sendo um elemento fundamental da qualidade na educação: "qualidade para poucos não é qualidade, é privilégio".

O termo "qualidade em educação", proporciona muitas definições variando do parecer que se tenha sobre o que esses processos devem favorecer à sociedade. Uma educação de qualidade pode ter alguns significados que possibilitam a eficácia dos conteúdos que compõem o sistema de ensino; podendo também adquirir um conhecimento científico, pode desenvolver o senso crítico fortalecendo a possibilidade do indivíduo para promover a transformação da realidade social.

A expressão "qualidade educacional" é uma referência a eficiência e a importância do setor educacional, dos sistemas educacionais e de suas instituições de ensino.

Para Moran (2013, p. 14), educação de qualidade pode ter as variáveis:

- Uma organização inovadora, aberta, dinâmica, com um projeto pedagógico coerente, aberto, participativo; com infraestrutura adequada, atualizada, confortável; tecnologias acessíveis, rápidas e renovadas. 
- Uma organização que congrega docentes bem preparados intelectual, emocional, comunicacional e eticamente; bem remunerados, motivados e com boas condições profissionais, e onde haja circunstâncias favoráveis a uma relação efetiva com os alunos que facilite conhecê-los, acompanhá-los, orientá-los.

- Uma organização que tenha alunos motivados, preparados intelectual e emocionalmente, com capacidade de gerenciamento pessoal e grupal.

Como prática social a escola evolui nas relações mantidas entre os grupos sociais, na escola e em outros ambientes da vida social, se mantém no campo social de disputa hegemônica, disputa essa que se dá "... na perspectiva de articular as concepções, a organização dos processos e dos conteúdos educativos da escola e, mais amplamente, nas diferentes esferas da vida social, aos interesses de classes" (FRIGOTTO, 1999, p. 25). Desta forma, a educação se forma numa atividade humana e histórica que se define na integralidade das relações sociais.

A educação escolar é uma das finalidades de políticas públicas, cumprem o seu papel nos processos de formação por vários níveis, etapas, modalidades e formas educativas. A educação formal desenvolve-se, pela mediação de instituições educativas, que orientam o processo ensino-aprendizagem estabelecidas pelos documentos norteadores do sistema educacional.

\section{FORMAÇÃO DOCENTE}

A formação docente para a educação básica atravessa por uma reconstrução dos saberes e fazeres tendo em vista o aprimoramento das competências e habilidades do profissional da área da educação.

Pimenta (1999, p. 19) reconhece a questão dos saberes como uma das dimensões consideradas nos estudos sobre a identidade da profissão do professor. Parte da proposição de que essa identidade é construída a partir da Significação social da profissão; da revisão constante dos significados sociais da profissão; da revisão das tradições.

Mas também da reafirmação das práticas consagradas culturalmente e que permanecem significativas. Práticas que resistem a inovações porque prenhes de saberes válidos às necessidades da realidade. Do confronto entre as teorias e as práticas, da análise sistemática das práticas à luz das teorias existentes, da construção de novas teorias.

0 papel da formação inicial visa prover as bases para construir um conhecimento pedagógico geral que capacita e proporciona conhecimentos sobre os processos de ensino/aprendizagem, metodologias necessárias para a reformulação do conteúdo a ser ensinado em conteúdo a ser aprendido e o conhecimento curricular, que se refere ao conhecimento das disciplinas que compõem o currículo de um determinado nível de ensino.

Muito se tem debatido sobre o assunto da formação de professores, podemos pensar em dois caminhos que se contemplam: o professor como aluno, e o professor como docente. Nessa perspectiva, podemos afirmar que o professor como docente e o professor aluno deve sempre buscar novos conhecimentos. Estas duas vias determinam que há perspectivas de estruturas diferenciadas na exploração de diversas questões relacionadas à formação continuada.

A formação profissional da docência se relaciona com as experiências e como as organizamos. Como diz Zabalza (2004, p. 222), "o sentido da aprendizagem não está na simples acumulação de informações, por mais especializada que ela seja, mas no desenvolvimento da capacidade para organizar essa informação e tirar proveito dela".

Dessa forma, o caminho da formação, segue um biótipo de aprendizagem que foi estruturada a partir da nossa vivência pessoal, escolar até os bancos da academia passando para o trabalho, formos inseridos nessa cultura para torça desconhecimentos e experiências e assim criamos a nossa identidade, por meio de experiências e aprendizagem de novos conhecimentos.

Importante é evidenciar que o período na trajetória docente nos anos iniciais é não somente é um período que irá aplicar o que aprendeu, mas é um período onde o seu aprendizado/conhecimento será acentuado pelo desenvolvimento de sua bagagem teórico metodológica. A inserção no mercado de trabalho é um momento valioso para o fortalecimento da sua atividade, bem como para a formação de sua individualidade profissional docente. 
Para entender sobre a formação dos profissionais do magistério da educação é necessário compreender o ponto de vista social e o campo do nível da política pública, ou seja, compete aos órgãos públicos promover e incentivar a formação continuada e gratuita, para que esses profissionais continuem se atualizando e buscando melhorias na sua formação.

No final do século XX, as políticas públicas passam a serem coordenadas pela reforma de Estado, que projeta modificações substantivas nos modelos de intervenção estatal, mudando a direção das formas de administração e, atingindo particularmente as políticas educacionais. Essas políticas passam por modificações importantes no mundo e principalmente no Brasil.

No Brasil, houve mudança no sentido das políticas educacionais e nos seus diversos espaços de decisão e efetivação. Houve mudanças políticas e ideias nos níveis da educação básica e superior, necessitando modificações de ordem jurídico-institucional nos processos de regulação e avaliação.

Foi aprovada a Lei no 9.131, de 24 de novembro de 1995, regulamentando o Conselho Nacional de Educação (CNE) e iniciando avaliações frequentes nas instituições e nos cursos superiores, assim como amplo processo de disputas, que marcaram a aprovação da Lei de Diretrizes e Bases da Educação Nacional - (LDB) - Lei no 9.394/1996. Em 2001, do Plano Nacional de Educação - (PNE) - Lei no 10.172, de 9 de janeiro de 2001.

O PNE esclarece os seguintes itens de políticas para a Educação Superior:

- $\quad$ variedade e especificação do sistema de ensino superior por meio de políticas de ampliação das Instituições de Ensino Superior (IES);

- $\quad$ avaliação da qualidade de ensino mediante sistema de provas;

- $\quad$ a inserção de tópicos específicos sobre o magistério: a educação básica e a educação à distância e novas tecnologias de informação, refletindo nos cursos de formação de professores.

\section{PROGRAMAS DE FORMAÇÃO}

O Ministério da Educação disponibiliza vários programas implantados em uma matriz educacional que associam em três direções: formação de qualidade; formação de professores e escola básica (graduação e pós-graduação); e produção de conhecimento. É de responsabilidade da CAPES a efetivação das formações bem como a valorizazação do magistério da educação básica. Esses programas propiciam acontecimentos de forma progressiva e de qualidade o aperfeiçoamento da formação docente.

Nos últimos anos esses programas foram evidenciados edirecionados a refletir sobre a formação de profissionais do magistério da educação básica, nos itens que dizem respeito as orientações pertinentes à formação inicial e continuada.

Conforme o MEC, Parecer nํ: 2/2015,

Em 2004 foi criada pelo MEC a Rede Nacional de Formação Continuada, com o objetivo de se obter uma maior organização entre os programas e os gestores de tais políticas; o comando da Capes expansão do objetivo de sua atuação ao incluir a formação de professores de educação básica; entre outros programas voltados à formação, destacam-se, o Programa Institucional de Bolsa de Iniciação à Docência - PIBID4, o Plano Nacional de Formação de Professores da Educação Básica - PARFOR, o Programa de consolidação das licenciaturas - Prodocência, a Rede Nacional de Formação Continuada, o Proletramento, a Formação no Pacto Nacional pela Alfabetização na Idade Certa. 0 apoio a cursos de segunda licenciatura, além de discussões sobre novas bases para a formação inicial e continuada, cursos experimentais de formação de professores direcionados à educação do campo e indígena. Tais perspectivas articulam-se, ainda, com políticas de inclusão e estímulo ao reconhecimento e respeito à diversidade que vão encontrar espaço no âmbito das Conferências Nacionais de Educação - Conferência Nacional de Educação Básica - Coneb, realizada em 2008, Conae 2010 e Conae 2014. (p. 6) 
O modo da educação básica brasileira reflete-se nas mudanças realizadas nos anos de 1990. Com a aprovação e efetivação da Lei de Diretrizes e Bases da Educação Nacional (LDB). Foram realizadas várias medidas sobre financiamentos para a educação, programas de avaliação educacional, políticas de formação de professores, sendo estabelecidas com o objetivo de melhoria de qualidade da educação.

Sobre a formação de professores, os artigos mais específicos da LDB ocorrem no Título VI: "Dos Profissionais da Educação", correspondendo aos artigos de 61 a 67.

Art. 61. A formação de profissionais da educação, de modo a atender aos objetivos dos diferentes níveis e modalidades de ensino e às características de cada fase do desenvolvimento do educando, terá como fundamentos: 20860

1o A União, o Distrito Federal, os Estados e os Municípios, em regime de colaboração, deverão promover a formação inicial, a continuada e a capacitação dos profissionais de magistério.

§ 2o A formação continuada e a capacitação dos profissionais de magistério poderão utilizar recursos e tecnologias de educação a distância.

§ 3o A formação inicial de profissionais de magistério dará preferência ao ensino presencial, subsidiariamente fazendo uso de recursos e tecnologias de educação a distância.

Na LDB, é garantida de acordo com a base comum nacional, a formação do profissional do magistério, baseando-se na formação teórica no ensino destinado para crianças, adolescentes, jovens e adultos; nas áreas do conhecimento científico, bem como a valorização dos profissionais da educação, entende-se, que a formação e a valorização desses profissionais, fazem parte da construção do princípio cognitivo e de formativo.

A Lei no 13005 de 25 de junho de 2014, que aprova o Plano Nacional de Educação, destaco, na LDB do artigo 61, as metas 15 a 18 e suas estratégias direcionadas aos profissionais do magistério da Educação Básica; Decreto n 6.755, de 29 de janeiro de 2009, que institui a Política Nacional de Formação de Profissionais do Magistério da Educação Básica, disciplina a atuação da Comissão de Aperfeiçoamento de Pessoal do Nível Superior (CAPES) estimulando os programas de formação inicial e continuada, e dá outras Resoluções e Pareceres do CNE sobre o tema abordado.

O Parecer considera as deliberações das Conferências Nacionais de Educação (CONAE) de 2010 e 2014 , bem como o longo processo de estudos, consultas e discussões, experiências e propostas inovadoras, resultados de pesquisa, indicadores educacionais, avaliações e perspectivas sobre a formação inicial e continuada para a educação básica, almejando, os desafios para o Estado brasileiro no com o objetivo certificar níveis de padrão para a qualidade de formação dos profissionais do magistério.

Na esfera do Conselho Nacional de Educação (CNE), pela equipe da Comissão Bicameral, aconteceu o trabalho com o objetivo de maior organização para a formação de profissionais do magistério da educação básica. Essa Comissão do CNE refere-se as normas para a formação de profissionais do magistério da educação básica, com o objetivo de estabelecer as Diretrizes Nacionais. Em 2013 e 2014, a Comissão realizou encontros de trabalho com as Secretarias do MEC, Instituto Nacional de Estudos e Pesquisas Educacionais (INEP), entidades acadêmico-científico e sindicais da área, Comissão de Aperfeiçoamento de Pessoal do Nível Superior (CAPES) e Instituto de Ensino Superior (IES), que foram discutidos o documento introdutório o qual deu a intenção de promover discussões, questionamentos e proposições em forte sintonia com a CONAE e com o PNE aprovado em 2014.

Todo esse esforço da Comissão se associa aos movimentos com a intenção de alcançar a sistematização das políticas, programas e ações atinentes à formação inicial e continuada.

A Comissão compreende que as discussões da Conae desempenham papel especial nesse processo, no sentido de que o documento final da CONAE 2010 e da CONAE 2014 avança ao dar importância discussão entre Sistema Nacional de Educação, as políticas e a valorização dos profissionais da educação e o faz situando quem são esses profissionais ao afirmar que, no âmbito de um sistema nacional de educação e no campo das políticas educacionais, a formação, o desenvolvimento profissional e a valorização dos(das) trabalhadores(as) da educação são partes constitutivas da agenda de discussão. 
O documento elaborado pela CONAE 2010 destaca, que a questão da profissionalização, que compõe a formação e à valorização dos profissionais da educação, tem provocado várias discussões no cenário educacional brasileiro, desencadeando políticas, assim como a mobilização de diversas dirigentes, com a intenção de constituir uma educação democrática para todos(as), com níveis nacionais de atributos para as instituições de ensino. Nessas discussões é destacado que as duas faces dessa política: formação e valorização profissional - são indissociáveis, no documento que foi finalizado e aprovado da CONAE (2014).

O documento da CONAE rege a igualdade de educação para todos, como fundamento para a formação de profissionais para a educação básica, em todas as suas partes (educação infantil, ensino fundamental e ensino médio) e variantes (educação de jovens e adultos, educação especial, educação profissional e técnica de nível médio, educação escolar indígena, educação do campo, educação escolar quilombola e educação a distância).

\section{COMPETÊNCIA DO PROFESSOR NO SÉCULO XXI}

É necessário que a educação do século XXI deve caminhar juntamente com as mudanças que a atual sociedade necessita como contribuição para a formação de um novo indivíduo. O conhecimento é um conjunto de ideias que nosso pensamento que deve seguir uma progressão de transformação, no que diz respeito as respostas prontas, sem que não proporcione ao estudante fazer indagações e/ou que apresente sua opinião. 20862

A formação para aprender a ser professor é um longo caminho a ser percorrido que vai muito além de conhecimentos específicos com metodologias, avaliações, etc. com os quais entramos em contato na universidade, está atrelado, também, com vários conhecimentos, experiências e métodos que só nos apropriamos quando nos inserimos no meio profissional através da entrada em um ambiente de trabalho e através da troca de conhecimentos com outros profissionais.

Ser professor é tem uma base teórica que lhe permita desconstruir e reconstruir seus conhecimentos, para que possa fazer uma análise sobre as atividades que desenvolve diariamente, podendo observar seu processo de formação.

O século XXI é marcado com algumas características, que o mundo atual necessita: a globalização e a necessidade de uma nova sociedade, chamada de sociedade do conhecimento. Essas mudanças proporcionam grande impacto na vida de cada pessoa.

A inovação tecnológica é um fator que proporciona uma facilidade em nosso dia a dia promovendo uma mudança em nossa sociedade. Exemplificando, diminui a distância de comunicação entre as pessoas, é possível armazenar grandes quantidades de materiais (fotos, textos, vídeos, etc.) em ambientes virtuais, entre outras facilidades que favorecem nossa vida diariamente.

Nesse sentido a inovação tecnológica, é o princípio que busca condições para amparar a formação do novo profissional no século XXI.

O novo profissional será capaz de: lidar com situação problemas, acompanhar a inovação tecnológica, saberá tomar decisões, trabalhar em equipes e ouvir as ideias das pessoas a sua volta. Esse profissional estará preparado para lidar com os desafios que irão surgir ao longo do tempo de sua carreira.

Conforme Marcelo Garcia (1999, p. 114), sobre o professor iniciante: "é um período em que o professor principiante se esforça por aceitar os estudantes, os colegas e supervisores, e tenta alcançar certo nível de segurança no modo como lida com os problemas e as questões do dia-a-dia". Essa é a nova identidade profissional do século XXI, deve ser proativo, estar sempre acompanhando as inovações e saber resolver os conflitos. Desta o trabalho docente realiza-se quando há interação com outros profissionais, quando se faz uma reflexão das ações que não deram certo e o profissional faz uma avaliação de suas metodologias.

O "Relatório Jacques Delors"- RJD - é o resultado dos trabalhos realizados, no período de 1993 a 1996 , pela Comissão Internacional sobre a Educação para o século XXI, da Organização das Nações Unidas para a Educação, Ciência e Cultura (UNESCO, 2001). Publicado no Brasil sob o título de Educação - um tesouro a descobrir apresenta que a educação deve transmitir novos saberes em relação a diversidade humana e ainda, deve auxiliar a descobrir a nós mesmos. Só então poderemos, verdadeiramente, nos colocar no lugar dos outros e compreender suas ações e reações.

Delors (2012, p. 89) afirma: “À educação cabe fornecer, de algum modo, os mapas de um mundo complexo e constantemente agitado e, ao mesmo tempo, a bússola que permite navegar através dele". Desta forma a 
formação pedagógica visa a formação de profissionais que deseja prover a máxima condição para uma educação de qualidade.

A concepção para a educação do século XXI, estrutura-se no princípio de quatro aprendizagens. Essas aprendizagens são fundamentais no decorrer da vida e são também conhecidas como de pilares da educação:

- $\quad$ aprender a conhecer: a pessoa está aberta para novos conhecimentos; para que isso ocorra faz-se necessário que a pessoa exercite a atenção, a memória e pensamento. 0 processo de conhecimento implica duração e aprofundamento da assimilação.

- $\quad$ aprender a fazer: não tem medo de errar, sabe que aprenderá e crescerá com o erro, diz respeito a comunicação e o desenvolvimento das pessoas, qualidades humanas que as formações tradicionais não transmitem necessariamente e que correspondem à capacidade de estabelecer relações estáveis e eficazes entre as pessoas;

- aprender a conviver, sabe conviver com o outro respeitando sua individualidade do próximo;

- aprender a ser talvez seja o mais importante, por explicitar o papel do cidadão e o objetivo de viver.

Esses quatro pilares da educação devem estar diariamente presentes nas políticas para a melhoria de uma educação de qualidade, pois, englobam o ser humano em formação em sua totalidade da aprendizagem.

No que se refere uma boa qualidade nos cursos de formação de professores poderá diminuir os valores das organizações de grandes investimentos de aprimoramento e formação continuada destinada a ensinar àqueles que, se tivessem compreendido a aprender, poderiam ser seus próprios professores da sua atualização profissional.

Com uma boa preparação de professores, a educação continuada poderia acontecer por meio de ambientes virtuais de aprendizagem ou na própria escola. 0 professor não necessitaria de se deslocar para outros locais. É importante enaltecer que uma formação de qualidade para o professor irá dar novos rumos as formações seguintes de professores e as ações de apoio às práticas pedagógicas dos docentes orientados.

A formação do professor, no que se atribui à sua função, deve proporcionar condições para estimular a busca de querer sempre mais, a procura para o aprimoramento do seu trabalho na perspectiva de mudanças significativas.

Como afirma Nóvoa (1992, p. 27),

A formação pode estimular o desenvolvimento profissional dos professores no quadro de uma autonomia contextualizada da profissão docente. Importa valorizar paradigmas de formação que promovam a preparação de professores reflexivos, que assumam a responsabilidade do seu próprio desenvolvimento profissional e que participem como protagonistas na implantação das políticas educativas.

Desta forma, acentua que uma boa qualidade de formação certifica o docente para ser reflexivo e crítico, diante das situações que surgirão na sua vida profissional, seja diante de novos modelos, se já diante de ideias que tentam impor uma visão de escola e de mundo.

\section{CONSIDERAÇÕES FINAIS}

Qualidade da educação é muito abrangente e visto por várias formas: adequação de melhoria de técnicas para alcançar novos objetivos ou como meio de mudança no currículo.

As legislações nacionais indicam que a profissionalização do educador está intimamente relacionada à sua formação, inicial e continuada, fazendo crer que o caminho para a profissionalização está pautado em um tripé: formação, participação e experiência, ou seja, pressupondo a reunião de requisitos passados e presentes. Por outro lado, ao mesmo tempo em que indicam quem é profissional da educação, deixam a desejar quando têm que especificamente determinar em quais aspectos o profissional passará a ser valorizado a partir da aquisição dessa formação. 
As reformas educacionais apresentadas a partir dos anos de 1990 proporcionaram maior clareza aos professores enquanto mediadores de mudanças em nossa sociedade. Esses profissionais, na maioria das vezes, responsabilizados pelo sucesso ou insucesso dos programas ofertados pelo governo.

Os professores do século XXI precisam aprimorar as competências e habilidades na sua prática educativa, para que os estudantes possam cada vez mais motivados a aprender a conhecer, aprender a fazer, aprender a viver e aprender a ser, que são aprendizagens que farão parte da sua vida. Essas competências e habilidades estão relacionadas com a área pedagógica, que oferece maneiras para promover aprendizagem.

\section{REFERÊNCIAS}

[1] BRASIL. Conferência Nacional de Educação (CONAE) 2010. Documento Final. Referência. Brasília,2010. Disponível em http://conae.mec.gov.br/images/stories/pdf/pdf/documentos/documento_final.pdf. Acesso em 27 de maio 2015.

[2] BRASIL. Conferência Nacional de Educação (CONAE) 2014: Documento Referência. Brasília, 2014. Disponível em http://conae2014.mec.gov.br/images/pdf/doc_referencia.pdf. Acesso em 27 de maio 2015.

[3] BRASIL. Decreto $N^{\circ}$ 6.755, de 29 de janeiro de 2009. Institui a Política Nacional de Formação de Profissionais do Magistério da Educação Básica, disciplina a atuação da Coordenação de Aperfeiçoamento de Pessoal de Nível Superior - CAPES no fomento a programas de formação inicial e continuada, e dá outras providências. Diário Oficial da União, Brasília, 30 de janeiro de 2009.

[4] BRASIL. Lei $N^{\circ}$ 9.394, de 20 de dezembro de 1996. Estabelece as diretrizes e bases da educação nacional. Disponível em: http://www.planalto.gov.br/ccivil_03/Leis/L9394.htm . Acesso em 26 de agosto de 2009.

[5] BRASIL, Lei 13.005 de 25 de junho de 2014. Disponível em:

<http://www.jusbrasil.com.br/diarios/72231507/dou-edicao-extra-secao-1-26-06-2014-pg-1>. Acesso em 22 de junho 2015.

[6] DELORS, Jacques. Educação: um tesouro a descobrir. 7. ed. São Paulo: Cortez, 2012.

[7] FRIGOTTO, G. A produtividade da escola improdutiva. 5. ed. São Paulo: Cortez, 1999.

[8] GENTILI, Pablo, 1995. O discurso da qualidade como nova retórica conservadora no campo educacional . In: GENTILI, Pablo e Tomaz Tadeu da Silva, orgs. Neoliberalismo, qualidade total e educação: visões críticas . Petrópolis: Vozes, 1995.

[9] MEC. PARECER no 2. Diretrizes Curriculares Nacionais para a Formação Inicial e Continuada dos Profissionais do Magistério da Educação Básica. Brasília: MEC, 2015.

[10] MEC. Documento Referência: Conferência Nacional de Educação. Brasília: MEC, 2009.

[11] MARCELO GARCIA, Carlos. Formação de professores. Para uma mudança educativa. Porto: Porto Editora, 1999.

[12] MORAN, José Manuel; MASETTO, Marcos T.; BEHRENS, Marilda Aparecida...Novas tecnologias e mediação pedagógica. 13aㅡ ed. Campinas: Papirus, 2013.

[13] NÓVOA, A. A formação de professores e profissão docente. In: NÓVOA, A. (Coord.) Os professores e sua formação. Lisboa: Dom Quixote, 1992. 20866

[14] OLIVEIRA, Mariah de. Educação e consciência. (Parte II). Disponível em: <http://www.vaniadiniz.pro.br/espaco_ecos/filosofia_virginia/mariah_de_oliviilri_educacao_e_consciencia_\%28parte \%20II\%29.htm>. Acesso em: 2 maio 2011.

[15] PIMENTA, S.G. Formação de professores: Identidade e saberes da docência. In: PIMENTA, S.G. (Org.) Saberes pedagógicos e atividades docente. São Paulo: Cortez, 1999.

[16] ZABALZA, M. A. O ensino universitário: seus cenários e seus protagonistas. Porto Alegre: ARTMED, 2004. 


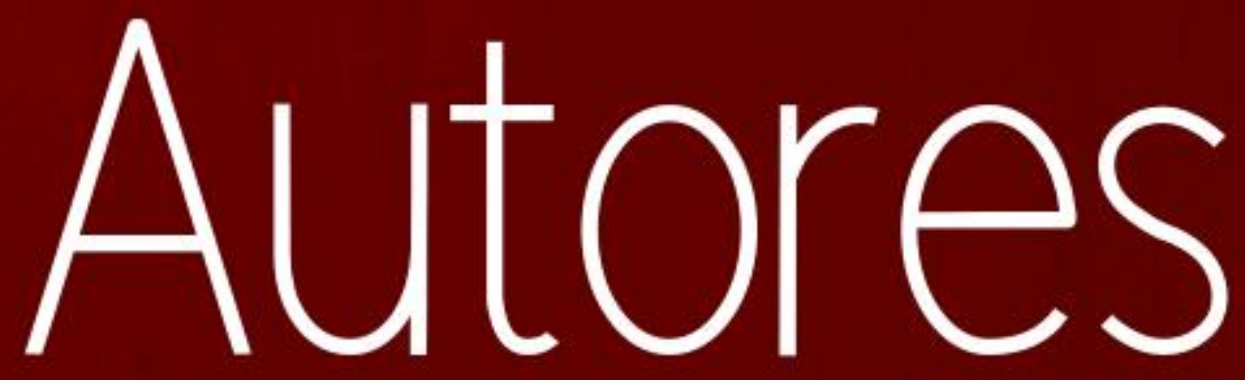




\section{ANA LÚCIA FERRAZ}

Mestranda - Ciência da Educação, Formada pela UNESP em Historia, Pós Graduada em Africanidades, Docência no Ensino Superior, Museografia, Pós Graduação em Educação Infantil, Professora na rede pública de São Paulo desde de 1998 até presente data

\section{ANA PAULA GASPAR MELIM}

Doutorado em Educação pela Universidade Católica Dom Bosco, Brasil(2016). Professor Titular da Universidade Católica Dom Bosco , Brasil

\section{ANDERSON ROCHA DE JESUS FERNANDES}

Possui graduação em Administração pela Universidade Federal de Minas Gerais - UFMG (2013). Possui mestrado em Administração, linha de pesquisa em Finanças pela Universidade Federal de Minas Gerais - CEPEAD/UFMG (2017). Doutorando em Demografia no Centro de Desenvolvimento e Planejamento Regional - CEDEPLAR da Universidade Federal de Minas Gerais - UFMG. Atuou como estagiário docente, ministrando a disciplina de mercado de capitais. Tem interesses na área de demografia econômica, mercado de trabalho e aposentadoria, desenvolvimento sustentável e métodos econométricos. Experiência em mercados financeiros, fundos de investimento e sustentabilidade e responsabilidade social. Atuação nos temas: desempenho de carteiras, aleatoriedade, empreendedorismo e cidades.

\section{ANTÔNIO ARTUR DE SOUZA}

Bacharel em Ciências Contábeis pela Universidade Federal de Santa Catarina em 1987, mestre em Engenharia de Produção também pela Universidade Federal de Santa Catarina, em 1990, e doutor em Management Science pela Universidade de Lancaster em 1995, na Inglaterra. Atualmente é professor Associado IV da Universidade Federal de Minas Gerais. Pós-doutor em Finanças pela Universidade de Grenoble, na França, em 2017. Tem experiência na área de Administração, com ênfase em Finanças e Ciências Contábeis, atuando principalmente nos seguintes temas: Administração Financeira, Orçamento Empresarial, Contabilidade Financeira, Planejamento Tributário, Contabilidade Gerencial e Análise de Custos.

\section{CARLA SARLO CARNEIRO CHRYSÓSTOMO}

Mestre em Educação Superior pela UNINI/PUERTO RICO; Especialista em Novas Tecnologias pela UNIVERSO; Pedagoga pela UNIFLU; Professora da Educação Básica há 37 anos; Professora das disciplinas pedagógicas do Curso de Pedagogia do ISEPAM e de outras Universidades; Experiência como docente da modalidade EJA no Estado do Rio de Janeiro; Experiência no campo da Alfabetização e Letramento no Estado do Rio de Janeiro; Coordenadora do Estágio Supervisionado do Curso de Pedagogia do ISEPAM; Professora de Curso preparatório para Concurso na área de Educação e Pedagoga do CRAS de Grussaí no município de São João da Barra/RJ.

\section{CELI TRAUDE KELLERMANN}

Mestre em Educação pela Universidade Estadual de Mato Grosso do Sul, Brasil(2016). Graduada em Pedagogia pela Universidade Estadual de Mato Grosso do Sul - UEMS e Graduada em Comunicação Social - Relações Públicas pela FEEVALE, Novo Hamburgo, RS. Professora efetiva da rede Municipal De Educação De Campo Grande - MS , Brasil

\section{CRISTIANA LARA CUNHA}

Graduada em Administração pela UFMG (2012) e Mestre em Finanças (2017) pelo CEPEAD- UFMG. Doutoranda em Administração pela Faculdade de Economia, Administração e Contabilidade da Universidade de São Paulo (FEA-USP). Tem experiência na área de Administração. Atuou como estagiária docente ministrando disciplinas de Empreendedorismo Social dos cursos diurno e noturno em Administração da FACE-UFMG (2016). Também atuou como estagiária docente na 
FEA-USP, monitorando a disciplina de Estruturas Organizacionais (2018) no curso de Administração. Foi também professora voluntária - Projeto Incluir- EICIS na Escola de Engenharia da UFMG (1o/2012 até 2o/ 2016). É pesquisadora do Programa de Gestão Estratégica para a Sustentabilidade Socioambiental (PROGESA) da FEA-USP, também do Grupo de Pesquisa em Direitos Humanos e Empresas (CDHeE) da FGV e do Núcleo de Empreendedorismo, Inovação, Conhecimento, Inteligência e Sustentabilidade (EICIS) do CEPEAD-UFMG. Faz parte da atual comissão científica do ENGEMA. Tem interesse nas áreas de: Sustentabilidade, Relatórios de Sustentabilidade, Materialidade, Certificações Sócio Ambientais, Empreendedorismo Social, Inovação Social, Finanças Sociais, Direitos Humanos, Microempreendedorismo e Microcrédito.

\section{DALTON BERTINI RUAS}

Professor da FAUUSP e participante do grupo "Lugares de Interação" do IAB-SP. Doutor em Arquitetura e Urbanismo pela FAUUSP, onde desenvolveu uma pesquisa sobre espaços escolares. Completou em 2017 o período de doutorado sanduíche na Universidade Nacional de Yokohama (YGSA) no Japão com bolsa de estudos oferecida pela CAPES. Concluiu mestrado como bolsista do Ministério da Educação e Cultura Japonesa (MEXT) pela Universidade Nacional de Yokohama (YGSA, 2010).

\section{DANIELA TOMIO}

Doutora em Educação Científica e Tecnológica. Professora na Universidade Regional de Blumenau, em cursos de licenciaturas e nos Programas de Pós-graduação Mestrado em Educação (PPGE) e Mestrado em Ensino de Ciências Naturais e Matemática (PPGECIM). Investiga sobre formação docente e práticas educativas na escola e em contextos de Educação Não Formal.

\section{DENISE SIMÕES RODRIGUES}

Área e temas de interesse: sociologia. Sociologia da Educação; sociologia da Cultura e do Imaginário. Trabalha com a análise das relações entre a sociedade, o poder e a educação, para a compreensão do processo de elaboração identitária cultural dos grupos, tendo âncora teórica Cornelius Castoriadis e Paulo Freire. Doutorado em Sociologia em 2001, na Universidade Federal do Ceará (UFC). Professora Titular da UEPA, ministra aulas nos cursos de graduação (Pedagogia), e no Programa de Pós-Graduação em Educação. Coordena pesquisas no campo das relações entre a Sociedade e a História da Educação na Amazônia e sobre Sociologia e suas interfaces com a Literatura. Professora Adjunto aposentada da Universidade Federal do Pará. Líder do Grupo de Pesquisa Sociedade, Ciência e Ideologia (SOCID), cadastrado no CNPq. Publicou o livro Revolução Cabana e Construção da Identidade Amazônica (Belém/PA, EDUEPA, 2009).

\section{EDNA MARIA MENDES PINHEIRO COSTA}

Graduada em Pedagogia pela Universidade Estadual do Maranhão (2011); Especialista em supervisão, Gestão e Planejamento Educacional- Instituto de Ensino Superior Franciscano (2008); Mestre em Docência e Gestão da Educação (Ramo: Administração Educacional - 2018). Atualmente é Técnica em Assuntos Educacionais do Instituto Federal de Educação, Ciência e Tecnologia do Maranhão.

\section{EDSON ROBERTO OAIGEN}

Possui Licenciatura Curta em Ciências Naturais e Exatas (1972); licenciatura plena em Biologia (1980); Especialização em Biologia Geral pela FISC/UNISINOS (1982); Mestrado em Educação pela Universidade Federal de Santa Maria (1990) e Doutorado em Educação pela Universidade Estadual de Campinas (1995). Foi professor da Universidade de Santa Cruz do SUL-UNISC, no período de 1981-1997. Atuou também na Universidade Luterana do Brasil-ULBRA, de 1997 até 2011. Desde 2004 é professor convidado no Programa de Postgradoen Ciências de laEducación- Maestría, Doctorado e Postdoctorado - em Universidad Evangelica del Paraguay, desempenhando também a função de Coordenador Pedagógico do referido Programa. É professor da Faculdade São Francisco de Assis, Porto Alegre, RS. 


\section{ELIANE GREICE DAVANÇO NOGUEIRA}

Doutorado em Educação pela Universidade Estadual de Campinas, Brasil(2006). Professor Titular da Universidade Estadual de Mato Grosso do Sul , Brasil

\section{ELISA ANGÉLICA ALVES GUEDES}

Mestre em Educação Profissional pelo Programa de Pós-Graduação em Formação de Professores e Práticas Interdisciplinares (PPGFPPI - UPE/Campus Petrolina-PE - 2017). Bacharel em Nutrição pela Universidade de Pernambuco, UPE/Campus Petrolina-PE (2014). Pós-Graduada em Gestão Ambiental pela Faculdades Montenegro/Polo Petrolina-PE (2010). Licenciada em Ciências Biológicas, UPE/Campus Petrolina (2008). Atualmente realiza atendimento clínico e ministra as disciplinas de Nutrição e Dietética e de Nutrição Aplicada a Enfermagem.

\section{FÁBIO ANDRÉ PORTO ALVES}

Graduação em História pela UPE- Campus Petrolina (2008).Mestre em Educação pelo Programa de Pós-Graduação Formação de Professores e Práticas Interdisciplinares (PPGFPPI) Mestrado Profissional em Educação da UPE-Campus Petrolina(2017). Professor Efetivo do IF Sertão PE Campus St ${ }^{\underline{a}} M^{\underline{a}}$ da Boa Vista. Área de ensino de História na educação básica e na formação de Professores em nível superior, pesquisas realizadas na linha de História Local e Regional, Educação Básica, no Ensino Superior (Formação de Professores) e Educação Contextualizada para

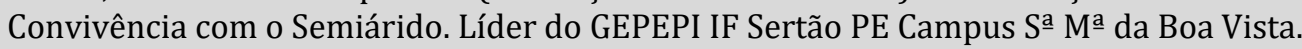

\section{FRANCISCO JUCIVÃNIO FÉLIX DE SOUSA}

Mestre em Gestão e Avaliação da Educação Pública pela Universidade Federal de Juiz de Fora PPGP/UFJF, especialista em Gestão de Políticas Publicas pela UFJF e em Ensino de Matemática pela Universidade Estadual do Ceará (UECE), graduado em Administração de Empresas (2012) pela Universidade Federal do Ceará e Licenciado em Matemática (2004) pela mesma universidade. Atualmente é Professor efetivo do Instituto Federal de Educação, Ciência e Tecnologia do Ceará IFCE, Campus Crateús.

\section{GISLENE MIOTTO CATOLOLINO RAYMUNDO}

Possui graduação em Pedagogia pela Universidade Estadual de Maringá (1990); Mestrado em Fundamentos da Educação pela Universidade Estadual de Maringá (1998); Doutorado em Educação: Currículo - PUC- SP (2011). É professora do Instituto Federal de Santa Catarina no Centro de Referência em Formação e EaD. Integrante do grupo de pesquisa: Gerações: Grupo de estudos e pesquisas sobre os sujeitos da Educação Profissional e Tecnológica. Tem experiência como professora e coordenadora de ensino na modalidade presencial e a distância. Faz parte do Banco de Avaliadores do Sinaes (BASis), pelo Ministério da Educação, para atos regulatórios institucionais, e também, atos regulatórios de curso e credenciamento na modalidade presencial e a distância. Tem experiência na área de Educação, com ênfase em Avaliação, Instituições, Planos e Programas Educacionais, atuando principalmente nos seguintes temas: educação, avaliação, formação de professores, novas tecnologias, aprendizagem e educação a distância.

\section{GLEDSON LIMA ALVES}

Psicólogo pela UNIT/SE; Especialista Cognitivo-Comportamental pela FACCAT/SC; Mestre em Educação pela UNIT.

\section{ISABELA ARAÚJO LIMA}

Bacharel em Arquitetura e Urbanismo pela UNIT/SE; Bacharel em Direito pela FANESE/SE; Mestra em Educação pela UNIT/SE 


\section{IVO JOSÉ BOTH}

Professor, escritor Doutor em Educação: política educativa

\section{JOSÉ MOISÉS MONTEIRO}

Graduação em História e Filosofia. Especialista em Metodologia do Ensino Fundamental e Médio - o Ensino de História - UECE. Professor efetivo da rede estadual de ensino no estado do Ceará. Gestão Escolar pela Universidade de Santa Catarina e Gestão da Educação Pública - Universidade Federal de Juiz de Fora. Atualmente exerce a função de Diretor Administrativo na Escola de Ensino Médio Josefa Alves Bezerrra, São Pedro do Norte, Jucás - CE.

\section{JULIO CEZAR ARIAS}

Pós-graduado em Planejamento e Gerenciamento Estratégico e também no curso de Formação de Professor Universitário. Graduado em Administração, todos pela PUC/PR. Possui experiência no ramo bancário, na área de vendas/comercial, recursos humanos, compliance, gestão de riscos, controles internos e auditoria. Intercâmbio pela LSC - Language Studies of Canada - Vancouver.

\section{KÁTIA MARIA KASPER}

Doutora em Educação pela Universidade Estadual de Campinas (UNICAMP). Pós-Doutora pela Universidade Estadual Paulista (UNESP). Professora do Setor de Educação da Universidade Federal do Paraná, do Programa de Pós-Graduação em Educação: Teoria e Prática de Ensino (PPGETPEn/UFPR) e do Programa de Pós-Graduação em Educação em Ciências e em Matemática (PPGECM/UFPR). Tem experiência na área de Educação, com ênfase nos estudos que privilegiam os processos de singularização e diferenciação; atuando principalmente nos seguintes temas: relações entre corpo e pensamento (especialmente com Gilles Deleuze, Félix Guattari, Michel Foucault); corpo, arte e subjetividade; educação, arte e políticas de subjetivação; clown; ecosofia; educação e processos de criação; formação.

\section{LUZIA MÔNICA LIMA DA FROTA ARAÚJO}

Doutoranda em Políticas Públicas pela Universidade Estadual do Ceará, Mestre em Sociologia pela Universidade Estadual do Ceará, graduação em Ciências Sociais pela Universidade Estadual do Ceará, graduada em Psicologia pela Universidade de Fortaleza, professora da Educação básica no Estado Ceará.

\section{MAILSON MARTINHO}

LICENCIADO PEDAGOGIA - Universidade Metropolitana de Santos(2012), LICENCIADO EM QUÍMICA - IFMA -(2015) e BACHAREL EM TEOLOGIA LIVRE -Faculdade Teológica Nacional (2015). Especialista em Supervisão, Gestão e Planejamento Educacional pelo Instituto de Ensino Superior Franciscano.Professor E.M.Silvestre Fernandes Rocha e Técnico em Assuntos Educacionais do Instituto Federal de Educação, Ciência e Tecnologia do Maranhão - Campus Zé Doca.

\section{MARIA DE LOURDES SILVA LIMA}

Graduação em Pedagogia - Universidade Estadual do Maranhão (2011); graduada em Ciências Habilitação em Biologia - UEMA (2015); pós-graduada em Supervisão Escolar- U. Cândido Mendes do MA (2002); pós-graduada em Gestão Educacional pela Faculdade Mário Schenberg (2015); Servidora Pública Estadual -Secretaria de Estado de Educação do Maranhão; Servidora Pública Federal do Instituto Federal de Educação, Ciência e Tecnologia do Maranhão - IFMA. 


\section{MARIA DOS ANJOS LOPES VIELLA}

Doutora em educação pela Universidade Federal da Santa Catarina (2008), mestre em Educação pela Universidade Federal de Minas Gerais (1987) e graduada em Pedagogia pela Universidade Federal de Viçosa- MG (1976). Professora do Mestrado Profissional em Educação Profissional e Tecnológica em Rede Nacional (PROFEPT) ofertado pelo Centro de Referência em Formação e EaD do Instituto Federal de Educação, Ciência e Tecnologia de Santa Catarina (IFSC); Líder do Grupo de Pesquisa "Gerações :Sujeitos da Educação Profissional e Tecnológica". Tem experiência na área de Educação, com ênfase em Educação e Trabalho, Ensino e Formação de Professores, pesquisando os seguintes temas: Mundo do trabalho, juventude e escola, pesquisa e formação de professores e formação de professores para a Educação Profissional e Tecnológica.

\section{MARIA EVEUMA DE OLIVEIRA}

Mestre em Letras pela Universidade do Estado do Rio Grande do Norte, campus Pau dos Ferros, UERN/RN. Especialista em Língua Portuguesa, URCA 1996-1998. Mídias da Educação,UFC, 20082010. Gestão Escolar, 2016-2018. Graduada em Letras pela Universidade Regional do Cariri, 19921995, URCA/CE. Formadora do Pacto Nacional pelo Fortalecimento do Ensino Médio, na Coordenadoria Regional de Desenvolvimento da Educação - CREDE 16, Iguatu- CE, 2014/2015. Superintendente Escolar na Coordenadoria Regional de Desenvolvimento da Educação - CREDE 16, 2015-2018. Atualmente exerce a função de Coordenadora Escolar na Escola de Ensino Profissional Professor Moreira de Sousa,Juazeiro do Norte - CE.

\section{MARIA LUCIENE ARAÚJO DA SILVA}

Especialista em Gestão Escolar, 2005 e Metodologia em Ensino Fundamental e Médio,2000. Graduada em Pedagogia, UECE1992. Professora efetiva do Estado do Ceará: Fundamental I, 19782001; Ensino Médio, 1997 - 2019. Exerceu o cargo de Monitora - FEBEMCE, 1976-2001. Extencionista Social, EMATERCE -2001-1997. Superintendente Escolar na Coordenadoria Regional de Desenvolvimento da Educação - Crede 14, 2013-2016. Atualmente exerce a função de Coordenadora Escolar na Escola de Ensino Médio Josefa Alves Bezera, São Pedro do Norte, JucásCE.

\section{MARIZETE BORTOLANZA SPESSATTO}

Professora do Centro de Referência em Formação e EaD do Instituto Federal de Educação, Ciência e Tecnologia de Santa Catarina (IFSC). Integra o Colegiado do Curso de Mestrado Profissional em Rede em Educação Profissional e Tecnológica-Polo IFSC. Doutora em Educação pela Universidade Federal de Santa Catarina (2011), com estágio de doutoramento na Università Degli Studi di Padova-Italia (2010). Mestre em Linguística pela UFSC (2001). Realizou, como bolsista PNPD/CAPES, Pós-Doutoramento junto à Universidade do Estado de Santa Catarina-UDESC, na linha de pesquisa Pesquisa Políticas Educacionais, Ensino e Formação.

\section{MARLENE DE OLIVEIRA}

Mestre em integração latino-americana. Pós graduada em ead e tecnologia educacional. pós graduada em comercio exterior e ciência politica. Pós graduada em turismo e hospitalidade. pós graduanda em psicopedagogia clinica e institucional. Graduada em bal secretariado executivo. autora de livros em secretariado e eventos. Atualmente docente efetiva do IFPR - Instituto Federal do Paraná. Coordenadora do curso de Tecnólogo em Secretariado e Pós em Gestão de Negócios

\section{MÉRCIA FREIRE ROCHA CORDEIRO MACHADO}

Possui Licenciatura em Educação Física pela Universidade Federal do Amazonas (1990), Especialização em Formação de Professores em Educação a Distância pela Universidade Federal do Paraná (2001), Especialização em Exercício e Qualidade de Vida pela Universidade Federal do Paraná (2001), Mestrado em Educação pela Pontifícia Universidade Católica do Paraná (2011) e Doutorado em Educação pela Pontifícia Universidade Católica do Paraná (2016). Atualmente é 
professora titular do Instituto Federal do Paraná e pesquisadora da Pontifícia Universidade Católica do Paraná. Tem experiência na área de Educação, atuando principalmente nas temáticas: educação a distância, educação profissional e tecnológica, formação de professores, mediação pedagógica e aprendizagem a distância.

\section{MICHELLE CARNEIRO SERRÃO}

Formada em Pedagogia, mestre em educação e doutoranda em educação pela Universidade Federal do Amazonas - UFAM. É professora assistente lotada na faculdade de educação da UFAM, e atua no curso de pedagogia.

\section{PATRÍCIA BERALDO}

Doutoranda pelo Programa de Pós-Graduação em Comunicação e Linguagens da Universidade Tuiuti do Paraná (PPGCom/UTP) - Linha de Pesquisa Processos Mediáticos e Práticas Comunicacionais. Mestre em Educação e Novas Tecnologias pelo Centro Universitário Internacional Uninter. Formada em Pedagogia - Habilitação em Tecnologia Educacional, pela PUC/PR. Especialista em Práticas Pedagógicas em Educação Infantil e Ensino Fundamental pela Universidade Positivo. Professora da Secretaria Municipal da Educação desde 2005. Atuo desde 2012 no Departamento de Tecnologia e Difusão Educacional.

\section{POLLYANA AGUIAR FONSECA SANTOS}

Mestre em Educação pelo Programa de Pós-Graduação em Educação: Teoria e Prática de Ensino da Universidade Federal do Paraná. Graduada em Licenciatura e Bacharelado em Geografia pela Universidade Federal do Paraná. Professora de Geografia da rede estadual de educação do Paraná desde 2009. Pesquisa processos educacionais, de formação e singularização.

\section{RAIMUNDA ABOU GEBRAN}

Licenciada em Geografia e Pedagogia e Doutora em Educação. Foi docente do Departamento de Educação da Universidade Julio de Mesquita Filho - UNESP, campus de Assis. Atualmente é professora permanente do Programa de Pós-Graduação em Educação (Mestrado) da Universidade do Oeste Paulista. É líder do Grupo de Pesquisa "Contexto Escolar e Processo de Ensino Aprendizagem - ações e interações (CONTEPEA)" e membro do Grupo de Pesquisa "Formação de Professores e Práticas de Ensino na Educação Básica e Superior" da Faculdade de Ciências e Tecnologia (FCT/Unesp). Tem experiência na área de Educação, com ênfase em metodologia do ensino e didática.

\section{ROCHELI RITA RONCHI}

Mestranda do Programa de Pós graduação em Educação (PPGE). Coordenadora de Educação no SESI/SC - Serviço Social da Indústria.

\section{RODRIGO LEME DIAS DE SOUZA}

Doutorando em Ciencias Empresariales y Sociales Aplicadas na Universidad de Ciencias Empresariales y Sociales Aplicadas em Buenos Aires - Argentina conveniada com a Universidade de Hochschule MAINZ (Alemanha). Especialista em Controladoria e Contabilidade Gerencial pela Faculdade de Ciências Contábeis e Administrativas e Avaré Conveniada pelo CRC/SP. Especialista em Gestão Pública no Centro Universitário Eurípedes da Rocha de Marília. Especialista em Auditoria pela UEPG - Universidade do Estado de Ponta Grossa. Graduação em Ciências Contábeis pela Faculdade de Ciências Contábeis e Administrativas de Avaré. Atualmente é Auditor da Prefeitura Municipal de Itaporanga (SP) e Docente de Graduação das Faculdades Integradas de Itararé - FAFIT, Faculdade de Arapoti - União Latino-Americana de Tecnologia - FATI e Docente de Pós Graduação na Universidade Norte Pioneiro do Paraná, Faculdade Santanna e Faculdade de Ponta Grossa, Perito Judicial e Empresário Imobiliário do Empreendimento Jardim Valle Verde. 


\section{RONALDO COSTA BARBOSA}

Mestre em Educação. Bacharel em Geografia e Licenciado em Geografia, História e Pedagogia. Possui especialização Lato Sensu em Metodologia de Ensino de História e Geografia e Educação de Jovens e Adultos. Atualmente atua na Rede Oficial de Ensino do Estado de São Paulo, na rede municipal de Araçatuba/SP e na rede privada. Participa do Grupo de Pesquisa Contexto escolar e processo de ensino aprendizagem: ações e interações na Universidade do Oeste Paulista. Tem experiência na área de Geografia, História e Filosofia e na alfabetização de Jovens e Adultos.

\section{RONALDO DA SILVA CORREA}

Licenciado em Matemática pela Universidade Federal de Mato Grosso do Sul, onde participou do Programa Institucional de Bolsas de Iniciação à Docência (Pibid). Atua na rede Estadual de Educação de Mato Grosso do Sul no Ensino Fundamental e Médio. Atualmente, é estudante de Mestrado em Ciências dos Materiais pela UFMS onde desenvolve estudos sobre Cristalização em Vidros para Aplicações em Dispositivos de Telecomunicações. .

\section{SABRINA ESPINELE DA SILVA}

Doutoranda e Mestre em Administração/Finanças pela Universidade Federal de Minas Gerais UFMG. Graduada em Controladoria e Finanças pela UFMG (2016). Possui interesse nas áreas de Administração Financeira, Avaliação de Carteiras, gestão de riscos, investimentos, finanças comportamentais e mercados financeiros.

\section{SANDREIA PANTOJA LOBATO}

Mestre em Psicologia pela Universidade Federal do Amazonas - UFAM. é professora assistente no instituto de ciências sociais, educação e zootecnia - ICSEZ no município de Parintins/AM. Atua em vários cursos, especialmente nos cursos de licenciatura, como pedagogia, educação física e artes visuais.

\section{SILVANA MARA LENTE}

Servidora Pública Estadual, lotada na Universidade do Estado de Mato Grosso (UNEMAT). Atua em gestão universitária, com experiência em planejamento estratégico participativo e mestra em Ciências da Educação com ênfase na Autoavaliação Institucional e Plano de Desenvolvimento Institucional.

\section{SIMONE EVANGELISTA FONSECA}

Bacharel em Administração pela Universidade Federal de Minas Gerais - UFMG (2012). Especialista em Gestão Estratégica de Negócios pelo Centro de Pós - Graduação e Pesquisas em Administração da Universidade Federal de Minas Gerais - CEPEAD/UFMG (2015). Mestre em Administração, linha de pesquisa em Finanças pela Universidade Federal de Minas Gerais - UFMG (2018). Doutoranda em Administração, linha de pesquisa em Finanças pela Universidade Federal de Minas Gerais UFMG (2018). Experiências e Interesses na área de Administração, Administração Financeira, Finanças Corporativas, Mercados Financeiro e de Capitais, Avaliação e Performance de Fundos de Investimentos, Empreendedorismo, Inovação, Sustentabilidade, Negócios e Finanças Sociais. Além das atuações acadêmicas, experiência profissional com atuações em empresas de pequeno, médio e grande porte.

\section{SOLANGE TERESINHA CARVALHO PISSOLATO}

Mestranda em Direito pela UNIMAR - Universidade de Marilial. Mestre em Educação pela Universidad Evangélica del Paraguay, UEP, Asunción, Paraguai(2018). Possui graduação em Administração - Faculdades Integradas de Diamantino, FID, Diamantino, Brasil (1993), Graduação em Serviço Social pela Universidade Estadual de Ponta Grossa (1988), Graduação em Ciências Contábeis - Faculdades Integradas de Diamantino, FID, Diamantino, Brasil (2002), Graduaçao em 
Enfermagem - Uned -Faculdade de Ciências Sociais e Aplicadas de Diamantino - MT (2010), Bacharel em Direito - UNEMAT - Universidade Estadual de Mato Grosso (2015). Desempenhou o cargo de Secretária Municipal de Saúde no município de Diamantino no período de 1989 a 1992. Presidente da Associação Comercial e Industrial de Diamantino-ACID nos períodos de 1998 a 2000 , 2000 a 2002 e 2002 a 2004. Professora Universitária na Universidade do Estado de Mato Grosso Campus Universitário de Diamantino, nos cursos de Administração e Direito, desde o ano de 2015 até a presente data.

\section{TADEU TEIXEIRA DE SOUZA}

Atualmente exerce a função de Orientador da Célula de Desenvolvimento da Escola e da Aprendizagem da Coordenadoria Regional de Desenvolvimento da Educação - Crede 16, professor Efetivo da rede Estadual do Ceará. Graduado em Ciências com habilitação Biologia (Universidade Regional do Cariri); Especialista em Informática na Educação (Universidade Federal do Ceará); Mestre em Ensino de Ciências (Centro Universitário Univates - RS).

\section{VANDERLEI SCHMITZ}

Mestre em Educação pela FURB. Professor da Educação Básica na rede pública e privada de ensino de Santa Catarina.

\section{VANILDA ALVES DA SILVA}

Licenciada em ciências com habilitação em Matemática (1995) - Faculdades Integradas de Dourados, especialista em Metodologia do Ensino Superior (1996) - na mesma instituição. É Mestre em Educação (2006) pela Universidade Federal de Mato Grosso do Sul. É Doutora em Educação (2018) pela Universidade Católica Dom Bosco em Campo Grande/MS. É Professora Adjunta DE da Universidade Federal de Mato Grosso do Sul - Campus Ponta Porã/MS (CPPP). Atua com Estágio Obrigatório em Matemática no Ensino Fundamental e Médio, Formação de Professores de Matemática e Etnomatemática. Foi Professora Concursada da Rede Municipal de Educação de dourados/MS. Coordenou o subprojeto de Matemática do PIBID - UFMS/CPPP.

\section{VERA REJANE GOMES}

Possui Licenciatura Plena em Pedagogia com Habilitação em Magistério Superior pela Universidade Federal do Piauí (UFPI). Especialista em Supervisão Escolar pela Universidade Salgado de Oliveira - RJ. Servidora pública federal do Instituto Federal de Educação, Ciência e Tecnologia do Maranhão IFMA / Campus Zé Doca, onde atua como pedagoga na Coordenadoria de Atividades Pedagógicas (CAP). Tem interesse por Pedagogia, Educação, Linguagem, EJA, Psicologia da Educação, Formação de Professores.

\section{ZAIRA DANTAS DE MIRANDA CAVALCANTI}

Possui graduação em Letras- Português e Inglês pela Universidade Católica de Pernambuco (1989) e Especialização em Psicopedagogia pela Universidade de Pernambuco, Campus Garanhuns (20012002). Mestre em Educação pelo Programa de Pós Graduação Stricto Sensu- Formação de Professores e Práticas Interdisciplinares- PPGFPPI (2017). É professora aposentada da Rede Estadual de Ensino de Pernambuco, e professora assistente do colegiado de Letras da Universidade de Pernambuco - Campus Petrolina, onde desenvolve atividades na área de ensino de Língua Inglesa. 


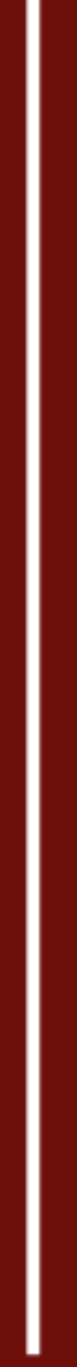

$\mid$ 